\title{
NEW DIRECTIONS IN \\ STRATEGIC THINKING 2.0
}

ANU STRATEGIC \& DEFENCE STUDIES CENTRE'S

GOLDEN ANNIVERSARY CONFERENCE PROCEEDINGS 



\section{NEW DIRECTIONS IN \\ STRATEGIC THINKING 2.0}

ANU STRATEGIC \& DEFENCE STUDIES CENTRE'S

GOLDEN ANNIVERSARY CONFERENCE PROCEEDINGS

\section{EDITED BY DR RUSSELL W. GLENN}

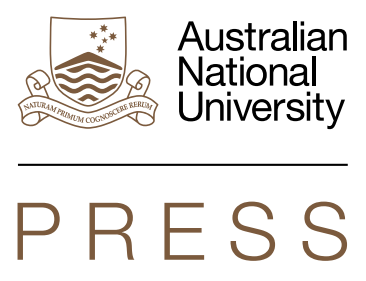




\section{ANU \\ PRESS}

Published by ANU Press

The Australian National University

Acton ACT 2601, Australia

Email: anupress@anu.edu.au

Available to download for free at press.anu.edu.au

ISBN (print): 9781760462222

ISBN (online): 9781760462239

WorldCat (print): 1042559418

WorldCat (online): 1042559355

DOI: 10.22459/NDST.07.2018

This title is published under a Creative Commons Attribution-NonCommercialNoDerivatives 4.0 International (CC BY-NC-ND 4.0).

\section{(c) (i) $(9$}

The full licence terms are available at

creativecommons.org/licenses/by-nc-nd/4.0/legalcode

Cover design and layout by ANU Press

This edition (C) 2018 ANU Press 


\section{Contents}

Foreword $\ldots \ldots \ldots \ldots \ldots \ldots \ldots \ldots \ldots \ldots \ldots \ldots \ldots \ldots \ldots \ldots$ vii

Preface........................

Contributors . . . . . . . . . . . . . . . . . . . . . . . . .xiii

Acronyms and abbreviations. . . . . . . . . . . . . . . xxiii

1. Introduction. . . . . . . . . . . . . . . . . . . . . . . .1 Russell W. Glenn

2. The decline of the classical model of military strategy $\ldots \ldots \ldots 9$ Lawrence Freedman

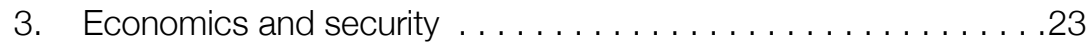
Amy King

4. A bias for action? The military as an element of national power . . 37 John J. Frewen

5. The prospects for a Great Power 'grand bargain' in East Asia . . .51 Evelyn Goh

6. Old wine in new bottles? The continued relevance of Cold War strategic concepts . . . . . . . . . . . . . . . . 63 Robert Ayson

7. Beyond 'hangovers': The new parameters of post-Cold War nuclear strategy. . . . . . . . . . . . . . . . . . . . . . .77 Nicola Leveringhaus

8. The return of geography $\ldots \ldots \ldots \ldots \ldots \ldots \ldots \ldots \ldots \ldots$ Paul Dibb

9. Strategic studies in practice: An Australian perspective . . . . . .105 Hugh White

10. Strategic studies in practice: A South-East Asian perspective . .117 Peter Ho 
11. American grand strategy in the post-Cold War era . . . . . . 133 Hal Brands

12. The future of strategic studies: Lessons from the last 'golden age' . . . . . . . . . . . . . . . . . . . . . . . . . 149 Hew Strachan

13. An Asian school of strategic studies? . . . . . . . . . . . . . . . 167 Amitav Acharya

14. The future of strategic studies: The next golden age . . . . . . 179 Robert O'Neill

15. Conclusion: What is the future of strategic studies? . . . . . . . 193 Paul Dibb

Appendix 1: Strategic \& Defence Studies Centre

50th anniversary celebratory dinner keynote speech:

'To see what is worth seeing' . . . . . . . . . . . . . . . . . . . . . .207

Brendan Sargeant

Appendix 2: Conference program . . . . . . . . . . . . . . . . 215

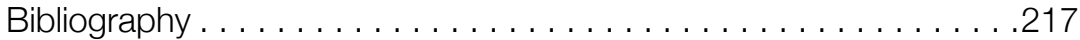




\section{Foreword}

The 50th anniversary conference of the Strategic \& Defence Studies Centre (SDSC), from which the essays in this volume are drawn, drew its inspiration from a similar event that Professors Robert O'Neill and David Horner hosted at The Australian National University in July 1980 under the theme 'New Directions in Strategic Thinking'.

There are some striking parallels between the period in which O'Neill and Horner held that conference-at the onset of the so-called second Cold War-and the world in which we find ourselves today. As Hedley Bull noted in his remarks to that earlier gathering:

In the late 1960s and the first few years of the 1970s, it was widely held in the Western world that the role of force in international relations had gone into decline ... A school of writers about international politics began to argue that the strategic factor in international power relationships was giving place to an economic factor ... Today, rightly or wrongly, [those ideas] are in large part rejected. In the Western world there is now a widespread expectation that the role of force will not diminish but increase - an expectation that is borne out by the evidence of mounting arms and arms expenditures in the Soviet bloc, the Third World and the West itself. ${ }^{1}$

Fifty years after SDSC's founding, geopolitics is making a comeback. The January 2018 National Defense Strategy of the United States of America, for instance, boldly asserts that interstate strategic competition, not terrorism, is now the primary concern in US national security ${ }^{2}{ }^{2}$ Talk of an

1 Hedley Bull, 'Force in international relations: The experience of the 1970s and prospects for the 1980s', in New Directions in Strategic Thinking, ed. Robert O’Neill and D.M. Horner, George Allen \& Unwin, London, 1981, p. 19.

2 US Department of Defense, Summary of the 2018 National Defense Strategy of the United States of America: Sharpening the American Military's Competitive Edge, Washington, DC, 2018, p. 1, www.defense.gov/Portals/1/Documents/pubs/2018-National-Defense-Strategy-Summary.pdf (retrieved 28 January 2018). 
emergent Asian arms race, spurred by North Korea's burgeoning nuclear and missile capabilities, is becoming increasingly prevalent, and respected commentators regard the chances of war breaking out on the Korean Peninsula as being as high as 50 per cent.

Scholars and practitioners alike, such as Harvard Professor Graham Allison and Chinese President Xi Jinping, have cautioned repeatedly on the dangers of China and the United States falling into a 'Thucydides trap' in a historical allusion to the strategic competition between Athens and Sparta 2,500 years ago, which tragically brought to an end a golden age in ancient Greece. Australian Prime Minister Malcolm Turnbull, who is equally fond of this historical analogy, has warned against taking the so-called Asian peace of recent decades for granted. As Turnbull observed in his keynote address to the June 2017 Shangri-La Dialogue in Singapore, 'the gathering clouds of uncertainty and instability are signals for all of us to play more active roles in protecting and shaping the future of this region. ${ }^{3}$

The need for high-quality strategic thinking is becoming increasingly urgent and apparent in the emerging landscape of international politics. Yet the world at large, and the Asia-Pacific region where much of this new era in strategic competition will be played out, is unfortunately starting from a lower-than-optimal base.

That is because the fate of strategic studies is intimately and inevitably tied to its international political and security milieu. For instance, the first two decades following its birth as a formal field of study in the late 1940s have been characterised as a 'golden age' of strategic studies. The primary focus of scholars during this period was with a set of dilemmas associated with the onset of the nuclear era, including how use of these devastating new weapons could be avoided, or at least controlled and limited should war involving their use ever break out.

In the radical political milieu of the late 1960s and early 1970s, however, strategic studies quickly fell out of fashion. The emergence of a strong anti-war sentiment in the United States rendered the study of such issues unfashionable and even distasteful. The so-called oil shocks of the 1970s shifted international focus more towards the potential use of economic

3 Malcolm Turnbull, 'IISS Shangri-La Dialogue 2017 Keynote Address', Singapore, 2 June 2017, p. 3 . 
weapons and saw greater emphasis given to the economic dimensions of security. A period of détente between the United States and the Soviet Union, coupled with the normalisation of US-China relations, rendered the prospects for interstate conflict even more remote.

As Bull's remarks to the July 1980 SDSC conference suggest, the renewal of US-Soviet tensions in the 1980s challenged these assumptions for a time. Within a decade, however, the Cold War was over, and by the early 1990s the Soviet Union had evaporated. A swathe of articles appeared that questioned whether strategic studies should even survive in an era that the prominent international relations scholar Francis Fukuyama famously characterised as marking the 'end of history'.

Fifty years following SDSC's founding, the question of whether strategic studies has any future is increasingly being answered resoundingly in the affirmative. Indeed, a strong case can be made that a new 'golden age' in the history of strategic studies is upon us. This is not only reflected in the significant expansion of the Centre that has occurred over the past half decade or so. It is also evident in the fact that new strategic studies programs are beginning to emerge throughout an Asia-Pacific region that in many respects has traditionally displayed an aversion towards studying use of force issues in any formal sense.

Some might see this more crowded landscape as posing a threat to the future of SDSC. Instead, it should be regarded as presenting an enormous opportunity. Some SDSC scholars, such as the late Desmond Ball, played an important advisory role in the establishment of Singapore's Institute of Defence and Strategic Studies (IDSS). IDSS is now, of course, part of the world-leading S. Rajaratnam School of International Studies and continues to enjoy a close and productive relationship with the Centre. To be sure, as Amitav Acharya observes in his contribution to this volume, the provision of similar intellectual leadership, particularly regionally, during this next 'golden age' will need to be undertaken with a considerable degree of sensitivity. That said, it is an aspiration that SDSC should not shy away from. The excellent set of essays in this volume provide an impressive foundation from which to begin.

Brendan Taylor

Former Head of Centre (2011-16)

Canberra, January 2018 



\section{Preface}

Twenty-five years before the conference recognised in these pages, The Australian National University's Strategic \& Defence Studies Centre (SDSC) marked its silver anniversary with a conference and resulting proceedings entitled New Directions in Strategic Thinking. SDSC marked the passage of another quarter century with a similar event graced by the offerings that follow: presentations by speakers from among the world's most renowned thinkers in their fields. The following were fortunate in serving on the Centre's faculty or staff in mid-2016: Joan Beaumont, John Blaxland, Jean Bou, Jack Bowers, Allison Cadzow, Andrew Carr, Aurore Chow, Rhys Crawley, Bel Curujo, Peter Dean, Stephan Fruehling, Robert (Bates) Gill, Russell Glenn, Chui Ling (Evelyn) Goh, Amy King, Tamara Leahy, Daniel Marston, Garth Pratten, Gregory Raymond, centre head Brendan Taylor, Helen Taylor, Joanne Wallis and Hugh White. These colleagues were joined by visiting professors and others holding honorary positions: Desmond Ball, Chris Barrie, Richard Brabin-Smith, Bob Breen, Leszek Buszynski, Paul Dibb, Peter Edwards, James Goldrick, John Gould, David Horner, Ron Huisken, John McFarlane, Anthony Milner, Sam Roggeveen and Clive Williams.

Select staff from the Coral Bell School of Asia Pacific Affairs and student volunteers were invaluable to the success of the conference. The former included Jasmine Henkel, Kerrie Hogan, Ashley Roge, Thea Gellerfy (Ross), Ravneet Deo and Elke Larsen. William Baulch, Matthew Bunten, Robert Cook, Matthew Gambrill, Nathan Randell, Brandon Smith and Bradley Wood provided student support.

Raoul Heinrichs assisted with the editing of this volume. Many thanks to our reviewers, Sheryn Lee of Macquarie University's Department of Security Studies and Criminology, and Stephen Meekin, retired major general and former Deputy Secretary of Defence. 
These men and women joined their forebears from the half-century since SDSC's founding in 1966 to offer their services to the university of which they were a part, its students, the Australian Government and international partners, and broader academic communities spanning the globe. In so doing, they collectively set the stage for yet another 50 years of service in a half-century that promises to be no less in need of insight, innovation and original thinking than the one before. 


\section{Contributors}

\section{Lawrence Freedman}

Keynote speaker

Professor Sir Lawrence Freedman was Professor of War Studies at King's College, London, from 1982 to 2014, and was Vice-Principal from 2003 to 2013. He was educated at Whitley Bay Grammar School and the Universities of Manchester, York and Oxford. Before joining King's College, he held research appointments at Nuffield College, Oxford, the International Institute for Strategic Studies (IISS) and the Royal Institute of International Affairs.

Sir Lawrence was appointed Official Historian of the Falklands Campaign in 1997, and in June 2009 he was appointed to serve as a member of the official inquiry into Britain and the Iraq War.

Sir Lawrence has written extensively on nuclear strategy and the Cold War, as well as commentating on contemporary security issues. Among his books are Kennedy's Wars: Berlin, Cuba, Laos and Vietnam (2000), The Evolution of Nuclear Strategy (third edition, 2004), Deterrence (2005) and the two-volume Official History of the Falklands Campaign (second edition, 2007). He has also written an Adelphi Paper, The Transformation in Strategic Affairs (2004).

A Choice of Enemies: America Confronts the Middle East won the 2009 Lionel Gelber Prize and Duke of Westminster Medal for Military Literature. Sir Lawrence's most recent book, Strategy: A History (2013), was awarded the W.J. McKenzie Book Prize by the Political Studies Association. 


\section{Amitav Acharya}

Professor of International Relations, School of International Service, American University, Washington, DC

Professor Acharya has held the UNESCO Chair in Transnational Challenges and Governance at American University since 2011. He was Professor of International Relations at York University in Toronto and Professor of Global Governance at the University of Bristol in the United Kingdom. He was a Fellow of the Asia Center, Harvard University, and Fellow of the Center for Business and Government at Harvard's John F. Kennedy School of Government. Professor Acharya was elected to the Christensen Fellowship at St Catherine's College, Oxford, in 2012, and held the Nelson Mandela Visiting Professorship in International Relations at Rhodes University, South Africa, in 2012-13. Professor Acharya was the first non-Western scholar to be elected President (for 2014-15) of the International Studies Association (ISA), the most recognised and influential global network of international studies scholars worldwide. His recent books include Constructing Global Order (2018), The End of American World Order (second edition, 2018), Constructing a Security Community in Southeast Asia (third edition, 2014), The Making of Southeast Asia (2013) and Whose Ideas Matter: Agency and Power in Asian Regionalism (2009). With Desmond Ball, he co-edited The Next Stage: Preventive Diplomacy and Security Cooperation in the Asia-Pacific Region (1999). His articles have appeared in leading international relations journals such as International Organization, International Security, International Studies Quarterly, Journal of Asian Studies, Journal of Peace Research and International Affairs and World Politics. He has received Distinguished Scholar Awards from the International Studies Association's Global South Caucus in 2015 and the International Organization Section in 2018.

\section{Robert Ayson}

Professor of Strategic Studies, Victoria University of Wellington

Professor Ayson is Professor of Strategic Studies at Victoria University of Wellington, where he works closely with the Centre for Strategic Studies. In New Zealand, he has also held academic positions at Massey University and the University of Waikato, and official positions with the New Zealand Government as an intelligence analyst and select committee adviser. Professor Ayson is an Honorary Professor at the New Zealand Defence Force Command and Staff College, and an Adjunct Professor at The Australian National University's Strategic \& Defence Studies Centre, where he was Director of Studies from 2002 to 2009. Professor Ayson 
gained his $\mathrm{PhD}$ in War Studies as a Commonwealth Scholar at King's College, London, and his MA as a Freyberg Scholar to ANU. His recent writings include Asia's Security (2015).

\section{Hal Brands}

Henry A. Kissinger Distinguished Professor of Global Affairs, School of Advanced International Studies, Johns Hopkins University

Hal Brands is the Henry A. Kissinger Distinguished Professor of Global Affairs at the Johns Hopkins University School of Advanced International Studies (SAIS) and a Senior Fellow at the Center for Strategic and Budgetary Assessments. He is the author, most recently, of American Grand Strategy in the Age of Trump (2018). His other books are Making the Unipolar Moment: US Foreign Policy and the Rise of the Post-Cold War Order (2016), What Good is Grand Strategy? Power and Purpose in American Statecraft from Harry S. Truman to George W. Bush (2014), Latin America's Cold War (2010), From Berlin to Baghdad: America's Search for Purpose in the Post-Cold War World (2008) and The Power of the Past: History and Statecraft (co-edited with Jeremi Suri, 2015). From 2015 to 2016, he served as special assistant to the Secretary of Defense for strategic planning, and he has consulted for a range of government offices and agencies and think tanks. He has also served as lead writer for the Commission on the National Defense Strategy of the United States.

\section{Paul Dibb}

Emeritus Professor, Strategic \& Defence Studies Centre,

The Australian National University

Emeritus Professor Dibb was Head of SDSC from 1991 to 2003. His previous positions include Deputy Secretary of the Department of Defence, Director of the Defence Intelligence Organisation and Head of the National Assessments Staff (National Intelligence Committee). As Deputy Secretary, he chaired the Force Structure Committee with the Vice Chief of the Defence Force as his deputy and the service chiefs as the other senior committee members. Emeritus Professor Dibb is the author of five books and four reports to government, as well as more than 150 academic articles and monographs about the security of the AsiaPacific region, the US alliance and Australia's defence policy. He wrote the 1986 Review of Australia's Defence Capabilities (the Dibb Report) and was the primary author of the 1987 Defence White Paper. His book The Soviet Union: The Incomplete Superpower was published by the International Institute for Strategic Studies (IISS), London, in 1986, then reprinted 
in 1987 and again in 1988. On behalf of the Department of Foreign Affairs and Trade (DFAT), Emeritus Professor Dibb has represented Australia at 10 meetings of the ASEAN Regional Forum's Expert and Eminent Persons group, most recently in Singapore in March 2016. He was a member of the Foreign Minister's policy advisory panel for the nine years of its existence until 2007. His areas of expertise include international security concepts, Asia-Pacific regional security issues and Australian defence policy and force structure. He was made a member of the Order of Australia in 1989.

\section{John J. Frewen}

Principal Deputy Director General, Australian Signals Directorate

Lieutenant General Frewen AM is a career infantry officer who specialised in rapid response forces. In 2003, as Commanding Officer of the 2nd Battalion, Royal Australian Regiment (2 RAR), he led a multinational military intervention force supporting police to re-establish law and order in Solomon Islands. This combined joint task force comprised almost 1,800 troops from five nations and used an array of air and maritime assets. Lieutenant General Frewen's other service includes deployments with the United Nations in Rwanda in 1994 and NATO in Afghanistan in 2007. At the time of writing, he was the Head of Military Strategic Commitments in Australian Defence Headquarters. He was the national commander of all Australian forces in the Middle East, including Iraq and Afghanistan, in 2017. John assumed the position of Principal Deputy Director General, Australian Signals Directorate, in March 2018.

\section{Russell W. Glenn}

Assistant Professor, Strategic \& Defence Studies Centre,

The Australian National University

Dr Russell W. Glenn retired from the US Army in 1997. He thereafter spent 16 years in the think tank community as a senior defence analyst, later joining the faculty of Strategic \& Defence Studies Centre at ANU. Dr Glenn is currently Director, Plans and Policy for the G-2, US Army Training and Doctrine Command. His education includes a Bachelor of Science degree from the United States Military Academy and master's degrees from the University of Southern California (MS, Systems Management), Stanford University (MS, Civil Engineering and MS, Operations Research) and the School of Advanced Military Studies (Master of Military Art and Science). He earned his PhD in American history from the University of Kansas with secondary fields of military 
history and political science. His books include Reading Athena's Dance Card: Men Against Fire in Vietnam (2000) and Rethinking Western Approaches to Counterinsurgency: Lessons from Post-Colonial Conflict (2015). He is author-editor of the forthcoming Trust and Leadership: The Australian Army Approach to Mission Command.

\section{Evelyn Goh}

Shedden Professor of Strategic Policy Studies, Strategic \& Defence Studies Centre, The Australian National University

Professor Goh has published widely on US-China relations and diplomatic history, regional order in East Asia, South-East Asian strategies towards great powers, and environmental security. Her latest book is The Struggle for Order: Hegemony, Hierarchy and Transition in Post-Cold War East Asia (2015). Professor Goh edited the volume Rising China's Influence in Developing Asia (2016), and is co-editor of the Cambridge Studies in International Relations book series with Christian Reus-Smit and Nicholas Wheeler. Professor Goh commenced at ANU in 2013, and has held positions at the Royal Holloway University of London (200813), the University of Oxford (2006-08) and S. Rajaratnam School of International Studies in Singapore (2002-05). She has held visiting fellowships at the Woodrow Wilson International Center for Scholars and the East-West Center, both in Washington, DC. Professor Goh's major project grants include a UK Economic and Social Research Council Mid-Career Fellowship, an East Asia Institute Fellowship and research grants from the British Academy, MacArthur Foundation, Sasakawa Peace Foundation and Chiang Ching-kuo Foundation. Professor Goh holds master's and doctoral degrees in international relations and an undergraduate degree in geography, all from the University of Oxford. She also holds a masters in environment and development from the University of Cambridge.

\section{Peter Ho}

Senior Adviser, Centre for Strategic Futures

Peter Ho is the Senior Adviser to the Centre for Strategic Futures and a Senior Fellow in the Civil Service College. He also chairs the Urban Redevelopment Authority of Singapore and the Social Science Research Council. When he retired in 2010 after 34 years of public service, Mr Ho was Head, Civil Service, which was concurrent with his other appointments of Permanent Secretary (Foreign Affairs), Permanent Secretary (National Security and Intelligence Coordination) and Permanent Secretary 
(Special Duties) in the Prime Minister's Office. Before that, he was Permanent Secretary (Defence). Mr Ho was also founding Chairman of the Maritime and Port Authority of Singapore.

\section{Amy King}

Lecturer, Strategic \& Defence Studies Centre,

The Australian National University

Dr King specialises in Chinese foreign and security policy, China-Japan relations and the international relations and security of the Asia-Pacific region. Dr King is the author of China-Japan Relations After World War II: Empire, Industry and War, 1949-1971, which was published by Cambridge University Press in 2016. It examines the post-war rebuilding of economic ties between the People's Republic of China and Japan. It also explains how and why Japan became China's most important economic partner in the aftermath of major war, and at a time when the two countries were still Cold War opponents. The book is based on hundreds of declassified documents from the Chinese Foreign Ministry Archive, gathered during extensive fieldwork in China between 2008 and 2012. Dr King received a DPhil in international relations from the University of Oxford, where she studied as a Rhodes Scholar. Her doctoral thesis was awarded Oxford's 2013 Dasturzada Dr Jal Pavry Memorial Prize. Dr King completed her MPhil in Modern Chinese Studies at the University of Oxford, BA Hons (First Class) in International Studies, and BBus in International Business at the University of South Australia.

\section{Nicola Leveringhaus}

Lecturer in War Studies (East Asian Security), Department of War Studies, School of Security Studies, King's College, London

Dr Leveringhaus specialises in Asian nuclear weapons issues, especially Chinese views of nuclear weapons, past and present, as well as ideas of responsibility in the global nuclear order. Nicola was previously Lecturer in International Politics in the Department of Politics at the University of Sheffield (2015-16), a British Academy Post-doctoral Fellow in the Department of Politics and International Relations at the University of Oxford (2012-15) and a Stipendiary Lecturer in International Relations for Trinity College, Oxford (2014-15). Funded by an ESRC British InterUniversity China Centre scholarship, she completed an MPhil in Modern Chinese Studies and DPhil in International Relations at St Antony's College, University of Oxford. She also holds an MSc in International Relations from the London School of Economics and Political Science, 
and a BScEcon (First Class Hons) in International Politics and Strategic Studies from the University of Aberystwyth. She has studied at Peking University and Tsinghua University in Beijing, China, and has worked at the Center for Nonproliferation Studies in Monterey, California. Her most recent book, China and Global Nuclear Order, from Estrangement to Active Engagement (2015), was nominated for the ECPR Hedley Bull Prize in 2017.

\section{Robert O’Neill}

Emeritus Professor, Strategic \& Defence Studies Centre, The Australian National University

Professor O'Neill AO FASSA was introduced to strategic studies by Captain Basil Liddell Hart and Professors Norman Gibbs and Michael Howard at Oxford, from 1961 to 1965 . He then served with the Australian Army in Vietnam from 1966 to 1967, and was mentioned in dispatches for his work. Professor O'Neill taught military history at the Royal Military College Duntroon from 1967 to 1969 . He then moved to the Department of International Relations at ANU and was appointed Head of the Strategic \& Defence Studies Centre in 1971. Between 1970 and 1982, he wrote Australia in the Korean War 1950-53, the two-volume official history of Australia's role in the Korean War. He relocated to London as Director of the International Institute for Strategic Studies (IISS), then to Oxford in 1987 as Chichele Professor of the History of War. He also chaired the Imperial War Museum and the Council of the IISS, and was a member of the Commonwealth War Graves Commission. Professor O'Neill returned to Australia in 2001 and chaired the Australian Strategic Policy Institute (2001-05). He served as a board member of the Lowy Institute for International Policy (2003-12) and Planning Director of the US Studies Centre, University of Sydney (2006-07). He is also a Fellow of the Australian Institute of International Affairs.

\section{Brendan Sargeant}

Honorary Professor, Strategic \& Defence Studies Centre, The Australian National University

Mr Sargeant retired from the Department of Defence in October 2017, where he was Acting Secretary from May to September of that year. From September 2013 to October 2017, he was the Associate Secretary of Defence. Prior to that appointment he was the Deputy Secretary Strategy. As Associate Secretary, he was responsible for oversight of the implementation of the First Principles Review, a major reform of Defence 
organisation and enterprise governance, planning, performance and risk management. He was principal author of the 2013 Defence White Paper. $\mathrm{Mr}$ Sargeant has degrees in English literature and political science.

\section{Hew Strachan}

Professor of International Relations, University of St Andrews

Sir Hew Strachan is a Life Fellow of Corpus Christi College, Cambridge, where he taught from 1975 to 1992, before becoming Professor of Modern History at Glasgow University from 1992 to 2001. He was Chichele Professor of the History of War at the University of Oxford and a Fellow of All Souls College (where he is now an Emeritus Fellow) from 2002 to 2015, and Director of the Oxford Program on the Changing Character of War (2003-12). He serves on the Strategic Advisory Panel of the Chief of the Defence Staff and on the UK Defence Academy Advisory Board, as well as being a Commonwealth War Graves Commissioner and a member of the national committees for the centenary of World War I of the United Kingdom and France. In 2010, Sir Hew chaired a task force on the implementation of the Armed Forces Covenant for the Prime Minister. In 2011, he was the inaugural Humanitas Visiting Professor in War Studies at the University of Cambridge and became a specialist adviser to the Joint Committee on the National Security Strategy. He is also Brigadier in the Queen's Bodyguard for Scotland (Royal Company of Archers). In December 2012, Foreign Policy magazine included Sir Hew in its list of top global thinkers for the year. He was knighted in the 2013 New Year's Honours and was appointed Lord Lieutenant of Tweeddale in 2014. His recent publications include The Politics of the British Army (1997), The First World War: To Arms (2001), The First World War: A New Illustrated History (2003) and The Direction of War (2013).

\section{Brendan Taylor}

Associate Professor, Strategic \& Defence Studies Centre, The Australian National University

Dr Taylor's research specialises in major power strategic relations in the Asia Pacific, the US-Australia alliance and regional security architecture. He served as Head of the Strategic \& Defence Studies Centre from 2011 to 2016 and is co-editor (with Peter Dean) of Melbourne University Press's Defence Studies Series. Dr Taylor holds a PhD from ANU. His work has featured in leading international journals, including the Washington Quarterly, Pacific Review, Survival, Contemporary Southeast Asia, Asia Policy, Review of International Studies and International Affairs. He has 
written or edited eight books, including Sanctions as Grand Strategy for the International Institute for Strategic Studies' Adelphi Series. His book, Australia's American Alliance, co-edited with Stephan Frühling and Peter Dean, has become required reading at the Australian Department of Defence and the US Pentagon. His book on flashpoints in Asia is to be published by Black Inc. in 2018.

\section{Hugh White}

Professor, Strategic \& Defence Studies Centre,

The Australian National University

Professor White's research interests include Australian strategic and defence policy, Asia-Pacific security issues and global strategic affairs. He has worked on these issues since 1980 as an intelligence analyst, journalist, ministerial adviser, departmental official, think tanker and academic. Professor White was the principal author of Australia's 2000 Defence White Paper. His recent publications include Power Shift: Australia's Future Between Washington and Beijing (2010) and The China Choice: Why America Should Share Power (2012). In the 1970s, Professor White studied philosophy at Melbourne and Oxford universities. 



\section{Acronyms and abbreviations}

$\begin{array}{ll}\text { A2/AD } & \text { anti-access/anti-denial } \\ \text { ABM Treaty } & \text { Anti-Ballistic Missile Treaty } \\ \text { ADF } & \text { Australian Defence Force } \\ \text { ADIZ } & \text { air defence identification zone } \\ \text { AFP } & \text { Australian Federal Police } \\ \text { ANU } & \text { The Australian National University } \\ \text { ANZAM } & \text { Australian, New Zealand and Malaya } \\ \text { ANZUS } & \text { Australia, New Zealand, United States } \\ \text { APEC } & \text { Asia-Pacific Economic Cooperation } \\ \text { ASEAN } & \text { Association of Southeast Asian Nations } \\ \text { ASEAN-ISIS } & \text { ASEAN Institutes of International } \\ \text { ASIO } & \text { and Strategic Studies } \\ \text { AWACS } & \text { Australian Security and Intelligence Organisation } \\ \text { BRI } & \text { Airborne Warning and Control System } \\ \text { CANCAPS } & \text { Belt and Road Initiative } \\ \text { CASS } & \text { Canadian Consortium for Asia Pacific Security } \\ \text { CICIR } & \text { Chinese Academy of Social Sciences } \\ \text { CIIS } & \text { China Institutes of Contemporary } \\ \text { CIISS } & \text { International Relations } \\ \text { CSF } & \text { China Institute of International Studies } \\ \text { CTBT } & \text { China Institute for International and Strategic Studies } \\ \text { DFAT } & \text { Centre for Strategic Futures } \\ & \text { Comprehensive Test Ban Treaty } \\ & \text { Department of Foreign Affairs and Trade }\end{array}$


DIME diplomatic, information, military, economic

DIMEFIL diplomatic, information, military, economic, financial, intelligence and law enforcement

DoA Defence of Australia (policy)

DoD Department of Defense (United States)

EU European Union

G2 Intelligence section of a military service staff with a general officer commanding the unit

GDP gross domestic product

GRU Main Intelligence Administration (Russia)

IDSA Institute of Defence Studies and Analysis (India)

IDSS Institute of Defence and Strategic Studies (Singapore)

IED improvised explosive device

IISS International Institute for Strategic Studies (United Kingdom)

JFCOM Joint Forces Command (United States)

JI Jemaah Islamiyah (South-East Asian terrorist group)

KGB Committee for State Security (Russia)

KIDA Korean Institute for Defence Analysis (Republic of Korea)

MAD mutual assured destruction

MAS mutual assured safety

NAFTA North American Free Trade Agreement

NATO North Atlantic Treaty Organization

NFU no first use

NIDS National Institute for Defence Studies

NPT Non-Proliferation Treaty

NSC National Security Committee of Cabinet

NSC-68 National Security Council Report 68

NTS non-traditional security

OBOR One Belt, One Road 
$\mathrm{OKH} \quad$ Oberkommando des Heeres; Supreme Headquarters of the German Army (or German Army High Command) during World War II

OKW Oberkommando der Wehrmacht; Supreme Headquarters for German armed forces during World War II

ONA Office of National Assessments

OSB Operation Sovereign Borders

OTHR over-the-horizon radar

PLA

People's Liberation Army

$\mathrm{R} \& \mathrm{D}$

research and development

RAMSI

Regional Assistance Mission to Solomon Islands

RAND

An American think tank (from 'research and development')

RMA

revolution in military affairs

RSIS

S. Rajaratnam School of International Studies

SAC

Strategic Air Command (United States)

SALT

Strategic Arms Limitation Treaty

SDSC

Strategic \& Defence Studies Centre

SEATO

Southeast Asia Treaty Organization

SIPRI

Stockholm Peace Research Institute

$\mathrm{SP}+$

Scenario Planning Plus

START

Strategic Arms Reduction Treaty

TTCSP

Think Tanks and Civil Societies Program

UK

United Kingdom

US

United States

USAF

US Air Force

USDA

United States Department of Agriculture

USSR

Union of Soviet Socialist Republic 



\section{1 \\ Introduction}

Russell W. Glenn

July 1966 saw the founding of The Australian National University's Strategic \& Defence Studies Centre (SDSC). Fifty years later, the Centre celebrated its half-century of research, publication, teaching and informing government decision-makers with a two-day conference entitled 'New Directions in Strategic Thinking 2.0', the numerical designator being a tip of the hat to a similar event conducted, as noted in Dr Brendan Taylor's foreword, in 1980. That pair of days saw the podium graced by many of the world's premier thinkers in the strategic studies field. The evening between them brought together academics, practitioners and other honoured guests at a commemorative dinner held beneath the widespread wings of the ' $\mathrm{G}$ for George' bomber in the Australian War Memorial, an event privileged by speaker Brendan Sargeant, Associate Secretary of the Australian Department of Defence, and Professor Desmond Ball making one of his last public appearances.

The essays comprising the remaining chapters herein summarise the remarks provided by the conference's speakers. The sequence of their presentation maintains the thematic flow of the two days, all but the keynote speaker both providing initial remarks and later serving on a panel with colleagues addressing the themes noted in the agenda (see Appendix 2). ${ }^{1}$

1 Five speakers were unable to provide written contributions for this volume. 
Sir Lawrence Freedman, the conference's keynote speaker, addressed the decline of classical military strategy during and in the aftermath of the Cold War. Two fundamental elements of this decline were the diminishment of non-combatants' non-involvement as subjects of combat and the degradation of state acceptance of war's results in light of battle outcomes. In World War II, the first of these had became well established. Despite recognition of nuclear war's consequences, investigations of how such a conflict might be won continued, adaptations in conventional forces largely being in the service of supporting objectives during a nuclear exchange. So too non-state actors came to avoid confronting forces so equipped by turning to irregular warfare and thereby lengthening conflicts. Freedman concludes:

The challenge for the West in all of this is that wars have come to lack borders and endpoints. The idea of conflict as something contained in time and space, where there is a sharp demarcation between peace and war and between the civilian and military spheres, is consistently undermined. The classical model of warfare, of decisive campaigns, remains a beguiling ideal, but the real challenge for Western strategists is to come to terms with wars of continuing political struggle where military action ensuring a satisfactory political outcome have proved to be elusive.

SDSC's own Amy King followed Sir Lawrence and opened the 'Strategy and Power' panel presentations with her consideration of the relationship between economics and strategy. Economic growth, she observed, leads to growing demand for energy resources among states and thus can become a source of competition spurring international conflict. Similarly, economic decline can be a source of insecurity; states perceived to be in a state of decline might be more likely to take preventive military action in order to bolster their power position. Somewhat balancing these negative influences: recent international relations research points to an increasing linkage between economic interdependence and security. We find political-security tensions and thriving economic relations between China and Japan are not a contradiction but rather two sides of the same coin. Dr King observed that the world's most powerful state, the United States, is locked in a (albeit at times somewhat inconsistent) technological embrace with two rising competitors: China and India-this despite theoretical predictions that the United States should distrust and shun collaboration with these rival powers. She concludes that understanding such complexity requires avoiding previous approaches to analysis that separated economics and 
strategy while also suggesting that such studies must incorporate not only international considerations but also those internal that affect relationships between economics and security.

The Australian Army's Major General J.J. Frewen provided the first morning's third offering. He warns against conflating policy and strategy while noting that while strategy might have its historical origins in military affairs, it has evolved to become relevant to achieving broader national aims. Resultantly, the best national strategies are those that integrate all the elements of national power within a nation's means. Unfortunately, the United Kingdom's Chilcot Report ${ }^{2}$ on that country's involvement in Iraq concluded that recent national leaders can at times still rely too heavily on military capabilities alone, employing them in costly and uncoordinated ways. Major General Frewen concludes that Australia's situation is less dire than that of the United Kingdom. He nonetheless suggests that it would be wise to create an Office of National Strategy for, in the absence of a formal mechanism for national strategy, the potential is there for its military being deployed without clear definition of the intended purpose or being fully integrated with the other elements of national power, a situation unlikely to deliver an enduring solution to strategic challenges.

Professor Evelyn Goh concluded the 'Strategy and Power' panel presentations with her 'Grand power grand bargains: Myth or reality?', considering whether a US-China or Japan-China agreement to alter current negative relationships might be possible and what the character of those agreements might entail. Recognising that such bargains have historical precedent, Goh concludes that the post-Cold War emergence of US-Chinese economic ties constitutes the 'most important systemic context for a new bargain'. Yet Chinese perceptions that Japan and the United States have reneged on previous grand bargains undermines Chinese faith in such bargains, perhaps explaining to some extent what underlies China's reconsideration of its former 'biding time' policy and its recent willingness to challenge the existing order's status quo. Professor Goh concludes that compromises could conceivably facilitate a US-China grand bargain while recognising that the result will 'entail sea changes in attitudes and expectations on every side'.

2 United Kingdom Cabinet Office, The Report of the Iraq Inquiry [Chilcot Report], 6 July 2016; www.gov.uk/government/publications/the-report-of-the-iraq-inquiry (retrieved 16 January 2018). 
Professor Robert Ayson opened the first day's afternoon session regarding 'Strategic Thinking: Concepts and Challenges'. His 'Old wine in new bottles? The continued relevance of Cold War strategic concepts' considered adverse partnerships: partner relationships formed despite the parties being serious rivals. He cites Washington and Moscow. Although each defined strategic stability differently, the United States and Soviet Union recognised mutual survival during the Cold War as a core interest. Ayson questions whether the US-China relationship has a similar shared interest. He goes on to identify five factors underlying the Cold War partnership, concluding that US-China economic interdependence alone fails to meet this handful of factors, a cause for no little concern.

The legacy of the Cold War also underpins Nicola Leveringhaus's consideration of nuclear strategy in the aftermath of that conflict. Strategies from that period constitute 'conceptual hangovers' that strategists today struggle to improve upon. Her argument considers a series of post-Cold War time periods. The first saw nuclear deterrence lose its primacy given the emergence of weapons control and non-proliferation. The later 1990s saw a re-emergence of such primacy given detonation of devices by Pakistan and India while both countries also chose not to join the NonProliferation Treaty. Regional rather than worldwide nuclear strategies joined an arena previously limited to those of global scope. More recent strategic perceptions influencing strategic thought include the emergence of new technologies and attempts to delegitimise the weapons themselves.

Paul Dibb introduced discussion of Session 3-Strategy and Domainswith 'The return of geography'. His essay cites the historical foundations of Russian perceptions that the 14 newly independent states formed out of the Soviet Union's collapse had long been considered part of that country while also serving the critical role of securing its perimeter. Moscow therefore believes that these must be recognised as falling within Russia's sphere of influence. Geography also influences Russia's selfperception as not only a vital Asian power but also solidly a member of the European community rather than being but peripheral to its expanse. Not Europe and Asia then, but rather a post-Soviet Union Russia that conceives of a single Eurasian continent. Dibb then turns his attention to China, concluding that recent assertiveness by that country demands the United States and its allies-including Australia-demonstrate that such behaviour is unacceptable. Concerns regarding China's territorial bellicosity underlie both recent Defence White Paper elevation of South-East Asian security as Australia's most important strategic interest 
and emphasis that the country's 'relationship with Indonesia is vital', an importance reflected in Australia's upgrading of military facilities in its own north.

Day 2 opened with contemplation of 'Strategic Studies in Practice', the penultimate conference session. SDSC Professor Hugh White's essay provides the Australian perspective on the topic. He begins with a sweeping review of Australia's history from the first British landings to the present, thereby establishing a foundation for the country's present strategic options. He relates slippage in confidence regarding willingness of the United Kingdom and the United States to guarantee Australia's security, first when the United Kingdom failed to respond to German occupation of northern New Guinea in the 1880, and later with its 1968 'East of Suez' announcement. Questions arose regarding US commitment after Richard Nixon presented his 1969 Guam Doctrine. Although political stability and economic progress somewhat shielded the country from these shocks, Australia's leaders perceived the necessity for increased selfreliance and the emergence of 'Defence of Australia' as the underpinning of its security policy. US hegemony after the Cold War signalled a return to closer ties with the United States, ties reflected in increased military force interoperability and contribution of contingents when the hegemon led coalitions. The result, White concludes, is an Australia 'more comfortable relying on our allies for our security than we have been at any time since $1880^{\prime}$. Can this reliance continue in the face of Chinese assertiveness? The answer greatly relies on how seriously the United States is challenged in the region.

Singapore's Peter Ho next addressed the session topic, stressing the importance of the symbiotic relationship between history and security studies. While much of strategic studies rely on hindsight and historical insight, history's past cannot be relied on to demonstrate the future's trajectory. Perceptions in part explain this variance. Ho introduces the concept of a 'black elephant', a linkage of sorts regarding black swan incidents and the elephant in the room: events seemingly obvious that nonetheless surprise owing to an unwillingness to consider the possibility of their outcomes. How then can governments create plans and policies for the long term? Adopting methods aiding in the reduction of strategic shock are critical, methods strategic studies can assist in developing. Among their elements are maintaining a systematic view of the future, applying techniques such as looking for emerging issues and trends ('horizon scanning') that seek to better distinguish weak signals and emerging issues 
otherwise likely to be overlooked. Only with a more interdisciplinary approach than has been the norm, Ho assets, can strategic studies meet the demands of 21 st-century security challenges.

Four speakers addressed the conference audience on the fifth and final session's topic of 'New Directions in Strategic Studies'. Hal Brands' 'US grand strategy in the post-Cold War era' includes the author's 'three pervasive misconceptions': (1) that the country executed a dramatic break from its previous strategy; (2) the US post-Cold War grand strategy was ineffective; and (3) the world is seeing the end of US primacy, which will precipitate a fundamental retrenchment. Support of international peace and promotion of open and liberal economies were no less a priority post-1989 than before, goals consistent with long-standing US objectives. Brands highlights the prescience of the 1950 National Security Council Report 68 (NSC-68) outlining US efforts 'to foster a world environment in which the American system can survive and flourish', which constituted 'a policy which we would probably pursue even if there were no Soviet threat'. ${ }^{3}$ Nor do analyses decrying the failure of US strategy stand up to scrutiny. Promotion of democracy, a notably aggressive element of US policy after the Cold War, provides but one example. The world saw the number of electoral democracies increasing from 76 in 1990 to 120 some 15 years later. Addressing the third 'myth' of declining US primacy, Brands notes that such claims tend to overstate the significance of narrowing economic and other gaps. The United States' global military power, for example, remains unchallenged. While powers such as China might assert themselves regionally, no country can compete on the worldwide scale. US primacy might not last forever, but its disappearance-should it occur-is distant. The country should therefore seek to sustain a grand strategy in an era in which primacy remains, if perhaps in more contested environments. Brands concludes by offering five principles to support that sustainment.

Professor Sir Hew Strachan considered 'The future of strategic studies: Lessons from the last golden age'. Strategy in the aftermath of World War II underwent a dramatic shift from a focus on force employment to its containment. History saw a diminution in the eyes of strategists as a result, the importance of armed force in the 'golden age' now taking a back seat

3 National Security Council Report 68 (NSC-68), 'United States Objectives and Programs for National Security', 14 April 1950, fas.org/irp/offdocs/nsc-hst/nsc-68.htm (retrieved 30 January 2018). 
to consideration of how to bring about its limitation. Technology gained importance in the eyes not only of tacticians but also strategists. Strachan advises that it is the historian's responsibility to deal with discontinuities in history by accepting and dealing with 'contingency and shock' in an era during which, in Bernard Brodie's words, 'strategic studies were no longer focused on the waging of war but on its avoidance'. ${ }^{4}$

Amitav Acharya poses the question of whether the time has come for creation of an Asian school of security or strategic studies akin to the Copenhagen and English schools. Any such school is justified if it explains not just what happens in a country or region but additionally generates ideas that can travel beyond them to offer general or universal applicability. Unfortunately, he commiserates, current candidates do not qualify given this standard. It is a situation derivative in no small part due to 'entrapment', which Acharya describes as the links between states and think tanks or academics that undermine independent thought and expression of views incompatible with those of state sponsors. Those failing to adhere to state positions find themselves without funds and generally excluded from opportunities to continue presenting their research. He concluded by citing SDSC's Desmond Ball as 'the exemplary combination of academic rigour, scholarly independence and policy relevance' who could stand as an example to Asian scholars in overcoming such obstacles to creation of an Asian School.

The responsibility of concluding two days of session presentations and spirited exchange fell to Professor Robert O’Neill. He began his remarks with the observation that Australia's 'national record in the past for developing strategic policies has not been a distinguished one'. In the years immediately following World War II, this was in part attributable to strategy's development being solely an internal process with its military creators showing little interest in contributions from journalists, diplomats or academics. This changed somewhat in the 1960s, but political contributions were-with the notable exception of Percy Spender-confined to resource considerations: statements of what could and could not be afforded. The founding of SDSC in the late 1960s saw tentative steps towards offering advice, advice that drew on centre leaders' broadening experiences at London's International Institute for Strategic Studies. From those years, O'Neill identified 'necessary ingredients for the

4 Bernard Brodie, 'The absolute weapon', in Strategic Studies: A Reader, ed. Thomas G. Mahnken and Joseph A. Maiolo, Routledge, London, 2008. 
flourishing of strategic thought today' in organisations such as the Strategic $\&$ Defence Studies Centre: expert people, breadth of intellectual and field experience, a supportive underlying institution such as The Australian National University and bringing to bear both national and international perspectives. Nor, he warned, should academics alone be the source of advice, having 'found that a high proportion of our best contributions in debate, in conferences and in advice generally came from the civil service of the United Kingdom, other European NATO states, the United States and Canada'. Regardless, history is fundamental to strategic studies, offering as it does a past providing a basis for assessing new policies and warnings for those who might succumb to over-optimism, too great a reliance on technology and other shortfalls. So also do academics potentially have a notable role in bridging divides between countries as did Australians with Soviets in the Cold War years of the 1970s. Such observations are no less relevant in the 21 st century as security environments are ever evolving.

Paul Dibb provided the conclusion for this proceedings. It appears as the final chapter. 


\title{
2 \\ The decline of the classical model of military strategy
}

\author{
Lawrence Freedman
}

The classical model of military strategy, as described by the great theorists of the Napoleonic War, is the one to which contemporary strategists still aspire. It described how wars should be fought and so is best described as an ideal type in that it has always been understood that it would be difficult to realise this model in practice. According to this model, political objectives are achieved when enemy forces are no longer able to fight, preferably because they have been defeated in a decisive battle. Long wars can be accommodated in the classical model, but the best strategy offers a route to quick victory at tolerable cost. The essential feature is that warfare involves regular forces pitted against each other. Wars can be won by inspired commanders exploiting their strengths and the enemy's weaknesses almost independently of the underlying material strengths of the belligerent states. In its original form, this model involved two vital conventions: first, that non-combatants must be kept out of the frame; and second, that governments must accept the result of the fighting. Political gains would follow naturally from military gains.

The first of these conventions had been completely lost by the time of World War II. The non-combatant category had almost lost meaning as volunteers engaged in guerrilla warfare against an occupying army and populations came to be seen as legitimate targets either because by their everyday work they were supporting the war effort or else their 
subjugation was a war aim in itself. Yet the second convention still held. In the end, both World Wars I and II were decided as a result of a series of battles, their conclusions being marked by the surrender of the armies of one side to the other. But these were not wars that had been won so much by brilliantly conceived military operations as by the remorseless application of superior resources. In a book entitled The Revolution in Warfare, completed just as the Pacific War was concluded, the British strategist Basil Liddell Hart lamented the transformation of war 'from a fight to a process of destruction'. ${ }^{1}$

The idea of a military sphere with its own rules and conventions, which could be kept separate from a more innocent and safe civilian sphere, appeared to have been forever lost. All the history of that deadly century warned that battle would keep on bursting out of past boundaries, uncontainable in space or time, with civilians caught in the centre of the frame rather than kept safe at the margins. Technology had pushed states to total war as ever more sophisticated means were found to slaughter people on a large scale. Future conflict promised to be even more destructive. Even without atom bombs, centres of civilian population were still subjected to air raids during the Korean War. In the 1950s, there were successful tests of multi-megaton, city-busting, thermonuclear weapons.

In these circumstances, it was hard to expect that a war could take the form of a succession of battles leading to a military victory, as opposed to an escalating process of ever more horrendous devastation leading to mutual annihilation. The theorists of deterrence concluded that the only way to manage the situation was to embrace and then manage the destructiveness of modern weaponry. This required putting aside any thought of a nuclear battle with a clear victory. Once it was assumed that one side was preparing to fight a nuclear war, the assumption itself could result in massive instability and a catastrophe that might otherwise be avoided. Nonetheless, possible routes to a nuclear victory were still explored in think tanks and on military staffs, as if this might be possible if the right weapons were developed and deployed in the most effective way so as to disarm the enemy in a pre-emptive strike.

1 Basil Liddell Hart, The Revolution in Warfare, Faber, London, 1946, p. 33. 
The possibility of pre-emption was a natural concern for the United States as a result of Pearl Harbor. The fear of a bolt from the blue that would take out its most vital nuclear assets and leave them without any means of retaliation was given credibility in studies undertaken at RAND by a team led by Albert Wohlstetter. In 1954, its members demonstrated how the United States might be caught out with a pre-emptive strike by a calculating Soviet Union. This was not well received by RAND's client, the US Air Force's Strategic Air Command (USAF SAC). They considered it unrealistic in its modelling of a Soviet strike and unfortunate in suggesting that SAC needed to put effort into ensuring the survival of its own bombers rather than gear up for its own first strike. Wohlstetter considered SAC dangerously complacent and set about campaigning to have the vulnerability problem recognised. He lobbied in Washington, gave numerous briefings and went public with his anxieties. In an influential article on 'The Delicate Balance of Terror', he warned against assuming that just because both sides were acquiring sizeable stocks of weapons, the situation was becoming stable. Instead, he argued that stability would depend on many factors such as the range, yield and accuracy of weapons and the hardness and mobility of targets, along with issues of warning and sequencing. ${ }^{2}$

This approach encouraged the view that the stability of the nuclear balance could be known for sure only through complex calculations. It was not enough to assume that the possibility of mutual annihilation would scare political leaders away from rash actions. Both sides were seeking out advantage in new technologies, and the concern in the United States was that the Soviet Union was moving ahead in this race. Not only had it tested the first intercontinental ballistic missile, but also it had launched, in October 1957, the world's first artificial earth satellite: Sputnik 1. In the event, the US missile program was more successful than the Soviet Union's. Nevertheless, in Washington there was little confidence that a successful first strike could be launched without it turning out to be catastrophic and suicidal. By the mid-1960s, it was accepted that the prevailing condition was one of 'mutual assured destruction'.

Now that it was accepted, fatalistically, that any war would probably 'go nuclear' almost immediately, the major powers were scared into caution. This was not the result of complex analyses of the balance but

2 Albert Wohlstetter, 'The delicate balance of terror', Foreign Affairs, January, 1959, pp. 211-34. 
the smallest of risks of becoming involved in a nuclear exchange. Their nuclear arsenals were prepared for war, but their main function was to serve as a reminder that however deep the antagonism they should not let any disputes get out of hand. Wars had to be deterred, not fought. This left the task of designing, constructing and sustaining conventional armed forces extremely difficult. The word 'conventional' suggested some link with the past 'conventions' of classical warfare, but there was no obvious route to a decisive battlefield victory against a nuclear-armed opponent. Preparations for conventional war did not necessarily assume that a nuclear war could be avoided. Instead, the aim was to reinforce deterrence, for only an all-out conventional war was likely to create the conditions that could potentially bring about Armageddon. As a cold decision, a nuclear strike appeared irrational, but one that became more credible as something more emotional and hot-headed, taken in the fever of war, with casualties already accumulating and land torn apart as great offensives were launched and resisted.

A slightly more congenial possibility was that a defensive line might be held, or an enemy's advance made costly and painful, thereby allowing sufficient time for second thoughts and active negotiations, hopefully interrupting the nuclear powder trail before it reached its explosive climax.

The Americans were always deeply uncomfortable with this state of affairs. They were unnerved by the possibility of a war in Europe putting their homeland so directly at risk if matters escalated to nuclear exchanges and worried that if they made their anxiety on this matter too evident they would undermine the credibility of the deterrent and so help to create the situation they were desperate to avoid. From the early 1960s, they therefore began to press the Europeans to improve conventional forces so that at least there was no need to rush into the dire choice of suicide or surrender in the event of sudden aggression. While it might have been the case that the prospect of nuclear war ensured caution at time of crisis, this was not something upon which the Americans wished to rely. They worked to separate the nuclear from the conventional, with a firebreak between the two, and to encourage the North Atlantic Treaty Organization (NATO) to build up its conventional forces.

Eventually, in 1967, the doctrine of 'flexible response' was adopted whereby the Europeans recognised the US requirement for an extended conventional stage so that the first shots across the Iron Curtain would 
not lead automatically to a nuclear holocaust. In return, the United States accepted the need for a clear link between a land war in Europe and its own strategic nuclear arsenal.

By this time, the work was underway that would result in the transformation of conventional warfare. The most impressive development lay in the improved accuracy of modern weaponry. 'Smart' bombs were first employed during the USAF's Linebacker campaigns in the closing stages of US military involvement in the Vietnam War. Whereas once it might have taken numerous sorties for an important bridge to be destroyed, now this could be achieved with a single weapon. The success of air defence and anti-tank weapons during the opening stages of the October 1973 ArabIsraeli War encouraged confidence that the trend could include moving as well as fixed targets. Over time, the same accuracies could be achieved over ever-extending ranges and against a moving target, so long as it was in the open. With increasingly intrusive sensors it was also becoming possible to work out where enemy forces were and what they were up to. They could then be hit with a high probability of success. Liddell Hart had concluded in 1945 that the rot had set in to modern warfare when it was realised that air raids could not be used to hit specific military targets but instead only large civilian areas. 'Inaccuracy of weapon-aim resulted in inhumanity of war-aim. ${ }^{3}$ The corollary of this was that, if bomb aim was more accurate, so too could be war aim. War could become more of a fight. The trend away from decisive battle might at last be reversed.

But quick victories had proved to be elusive well before the nuclear age. If a war could not be won quickly then it tended to drag on with the advantages moving to those with the greatest financial, industrial and demographic strength — and therefore durability. The early evidence was that the new technologies would not necessarily support conventional offensives. The greatest beneficiaries of improvements in accuracy and lethality appeared to be defensive weapons, whether firing against aircraft, tanks or warships, so that future blitzkriegs would be even harder to execute. Anything in range and out in the open was vulnerable.

If frontal assaults were hazardous, then manoeuvrability appeared to be the best way to get around strong defensive positions. From their study of Warsaw Pact exercises and military literature, NATO planners concluded that their adversaries had put a lot of effort into developing armoured 
divisions and plans for moving fast to outflank NATO defences. ${ }^{4}$ This led to pressure for NATO to start preparing along the same lines, improving mobility to match that of the Warsaw Pact. Much more fluid and complex battles were envisaged. Their conduct would be facilitated not only by precise weaponry but also by improved means of intelligence-gathering, surveillance, command, control and communications. In this way, the digital revolution would make itself felt. A return to the classical model now seemed possible.

Eventually, in the GulfWar of 1991, the possibilities of the new technologies were revealed, albeit not against the Warsaw Pact but instead against a much weaker opponent that had adopted Soviet weaponry and tactics. The US-led coalition was able to fight an essentially classical conventional campaign to a swift and decisive conclusion and with limited casualties (especially on the coalition side). Here was a demonstration of the advantages American commanders enjoyed as a result of improvements in sensors, data management and communications as well as accuracy, so that Iraqi units were left stranded and picked off with ease while cruise missiles arrived at individual targets in the middle of built-up areas and destroyed them with minimal damage to any other buildings in the vicinity. The Iraqi military was swiftly rendered blind, deaf and dumb. Although the new capabilities were not quite as effective as some of the initial propaganda suggested, it did not take very much imagination to see how this form of warfare could be taken further. A rosy future for the US armed forces was at hand in which they might expect to be completely dominant. The combination of precision guidance and the new information technologies led to talk in the early 1990s of a 'revolution in military affairs' (RMA).

As the technology became even smarter, so the choices became sharper. Picking targets moved on from large military formations to specific units and then on to particular facilities - even in the middle of civilian areasand eventually, by this century, designated individuals. Unmanned drones controlled from a distance can now hover over an area, identify targets and, on command, attack them. The cumulative impact of all these developments has had a profound influence on Western military thinking.

4 Johan Holst and Uwe Nerlich (eds), Beyond Nuclear Deterrence: New Aims, New Arms, Crane Russak, New York, 1977.

5 See Lawrence Freedman, Strategy: A History, Oxford University Press, Oxford and New York, 2013, Chapter 16. 
Despite the fact that the new weaponry was employed against much weaker forces unable to fight back in kind, its successes encouraged the view that war in general could be turned away from its assumed totality and destructiveness. It raised the possibility of getting away from massive destruction and back to the classical view of war as a contest between regular forces acting apart from society. It has become possible to think again of non-combatant immunity as a real value. This was reinforced by the view, first developed as a result of the surveys conducted after World War II's massive bombing campaigns, that societies absorbed punishment in preference to surrendering and, if innocents were killed, then populations would be turned against the perpetrators. Consequently, a vicious and uncontained approach to war would be not only reprehensible but also counter-productive. With new technologies, large-scale killing need no longer be tolerated as an unavoidable consequence of war. Instead, the focus could be on disabling an enemy's military establishment with the minimum necessary force. Opponents would be defeated by means of confusion and disorientation rather than carnage. No more resources should be expended, assets ruined or blood shed than absolutely necessary to achieve specified political goals.

If wars had to be fought, this was the way to do it. There was a particular appeal here for the United States and its allies. High-quality weaponry reduced the importance of numbers while putting a premium on highquality troops. Now that bomb aim could be accurate, war aims could also be more precise. The key thing, however, was that these qualitative advantages were embedded in a massive material advantage.

The problem with this vision was not that it was technically out of reach. By and large, the weapons performed as advertised. The problem lay in the nature of the conflicts. The Americans always understood that there were high risks in becoming drawn into fighting insurgencies, as they had done in Vietnam. This explains their reluctance to get involved in lesser operations that had little to do with what they considered to be proper warfare against serious military powers. A brief and unsuccessful peacekeeping operation in Beirut in the early 1980s reinforced the lessons of Vietnam. It left no appetite for becoming involved in distant civil wars. Even without a Warsaw Pact to worry about, the focus remained on highintensity conflicts against delinquent states. There was scant interest in low-intensity interventions to keep squabbling populations apart, a task 
recognised as likely to be both thankless and enduring. The focus and preparations were on decisive battles against other great powers-so-called peer competitors.

Yet the wars of the first decade of the 21 st century came in response to an attack not from a revived Russia or an ascendant China but from the far end of the spectrum of threats. The most shocking perpetrator was not a powerful state but a terrorist group based in one of the poorest countries in the world. Al Qaeda organised an audacious attack against the symbols of US power. The attack employed one of the world's oldest weaponsknives-to hijack commercial airliners and turn them into deadly instruments of slaughter. Suddenly all the issues connected with 'weak', 'failing', 'fractured' or 'rogue' states acquired a harder edge. The response took the form of interventions that were not presented as discretionary nor, initially, as humanitarian in purpose. They were justified by the demands of national security.

Both the Afghan and Iraqi regimes were toppled by an unremitting display of US military capability. But, in both cases, this was followed by fury and frustration as it proved to be impossible for US forces to resolve bitter internal divisions.

Unfortunately, toppling regimes meant that they had to be replaced, lest elements of the old regime return. The short, sharp wars were followed by long, gruelling and inconclusive counter-insurgency campaigns. These required establishing security and setting these countries on their paths to reconstruction. This was easier said than done. The idea was to hand over to local forces to keep security on behalf of a local government, but this was continually delayed. Then, when it was eventually thought safe to leave, it turned out not to be the case. The insurgencies returned in more virulent forms. There had been a failure to grasp the challenges that would be faced reconstructing a deeply divided and brutalised society and helping its people settle on a new form of government. The transition from an invading force to an occupying administration was poorly handled. The military and political dimensions could not be treated separately.

These forms of warfare were the opposite of the ideal types of classical warfare. Instead of relatively civilised combat professionally conducted by high-quality regular forces, the struggle was against murky, subversive forms of terrorism and militias. Instead of directing fire with precision against targets of evident military value, they faced opponents whose 
strategies depended on maximising their enemies' pain. The harsh reality was of conflicts that were prolonged, doleful and disappointing. Old enemies refused to go away and new ones emerged, dragging the Americans and their allies into a continual, relentless war against opponents that for the most part preferred to remain hidden and, in many cases, were prepared to accept a martyr's death as human bombs. All the clichés of guerrilla warfare, dimly remembered from the 1960s, of an enemy hiding in the shadows and the tactics of darting flea bites, returned. The lessons of Vietnam had to be relearned, so US forces adapted to the demands of counter-insurgency and began to work out what it took to contain, if not quite defeat, their new foes.

These conflicts exposed flaws with the revived classical model as an ideal type. The technological advances came from the West, and only wealthy countries could afford the weapons. This meant that opponents could not fight on Western terms. This problem was identified early on as 'asymmetric warfare', capturing the theme that not everyone would or could fight in the same way. But it did not quite capture the extent to which those in weaker positions had no interest in keeping war apart from society. Their incentives were to use their own societies as sanctuaries and their opponents' societies as targets.

The ideal type involved a vision for land warfare that involved light and agile formations not too encumbered by the need to carry their own firepower (because precision strikes could be called in from distant bases), and possessing knowledge of the battlespace to be able to avoid enemy traps and move swiftly into favourable positions. By contrast, counterinsurgency campaigns required forces to move among potentially hostile populations, accepting the risk from ambush and improvised explosive devices (IEDs). This required very different tactics from the management of large, disciplined forces under firm command and deployed as part of a larger plan.

Although the new technologies made it possible to choose targets to avoid populated areas and civilian infrastructure, they also made it possible to choose targets with exactly the opposite intention: to put more rather than fewer non-combatant lives at risk. Compare, for example, the Russian air campaign that devastated the city of Aleppo in Syria with the air campaigns of the United States and its allies. 
As a result of Iraq and Afghanistan, the Obama Administration became reluctant to get involved in more wars of this type, at least on the ground. It could justify anti-terrorism campaigns employing targeted killing using drones, but at most that helped contain a particular sort of threat. Only by bringing a degree of stability and security to the contested areas that provided the bases and recruits from such groups as ISIS and al Qaeda could the threat be truly degraded, let alone eliminated. Much can be achieved from the air, but it does not bring victory by itself. Wars are fought for political influence and control. That requires holding territory and exercising authority within it. Either intervention forces had to use their own infantry or else they had to rely on indigenous forces, which often meant awkward compromises over political objectives and military methods.

Consider Russia as a country also engaged in conflicts beyond its borders and one that also is reluctant to commit substantial ground forces of its own. It was more effective in Syria where forces loyal to President Assad, along with those of Iran and Hezbollah, provided sufficient ground forces. In Eastern Ukraine, by contrast, although Russia provided considerable material support plus Special Forces, the separatists remained hemmed into much of their original area after September 2014.

These wars rarely involve battles. There might be rushes of activity as one force is pushed out of a presumed stronghold, with frightened people scampering away after their supposed protectors have fled. At other times, the fighting might be marked by sporadic bursts of artillery and IEDs but otherwise little of note happening for weeks and months. Then some spark, perhaps a new atrocity or food shortages or a change in the weather, leads to another bout of killing and more pleas to desist. Protest movements morph into militias and then militias morph into criminal gangs or into rival factions, fighting each other with the same ferocity that they once fought their shared enemy. This is one reason why it is hard to bring conflicts to a definitive conclusion. For many of those involved in local militias, there are too many opportunities connected with trafficking in drugs, minerals, people and guns to allow a profitable activity to come to an end.

Nor were the militias and terrorists innocent of the new technologies. Their smart phones provided many of the new capabilities that made the RMA possible, offering access to vast stores of knowledge on an infinite number of topics, imagery of local terrain, navigation and instantaneous 
communications. They could also often gain access to modern weaponry, whether from patrons and dealers or picked up from government forces that had fled rather than fought. Artillery and small arms were readily available. Sometimes portable anti-air weapons and even tanks could be found. There was always the possibility of improvisation-for example, by sticking machine guns onto the top of trucks. Of course, irregular forces lacked the training and discipline of the best regular forces, but they could improve over time. Their vulnerability was to air power. They could be spotted and destroyed if they moved out into the open.

The success of counter-insurgency campaigns could not be measured by victories in battle, but by the authority of the government or whatever political force was being backed. The critical effects were not those an armed force had on another, but those it had on the adversary's political and social structures. From this came a view that a key feature of modern conflict lay in the ability to shape public opinion, about whether opponents could cope and who would prevail and whether there would be much to benefit ordinary people either way. This led to talk of narratives and information operations as being no less essential to success than more traditional forms of kinetic activity.

The problem with this lay not in the appreciation of the importance of prevailing perceptions of a conflict but in the ability to influence those perceptions and the potential consequences of the changed perceptions. The problem for those who sought to control the perceptions of others was that they could rarely control the totality of communications from their 'side'. The most eloquent messages are often unintended, resulting from either the actions of careless troops or the policy statements of careless politicians. Reactions to being treated harshly and disdainfully for no good reason, especially by uninvited foreign troops, were not likely to vary greatly among otherwise diverse cultures. It would take more than a keen and well-resourced public affairs outfit putting a positive 'spin' on events to repair the damage in the aftermath of such behaviour. Most importantly, it would require evidence that policies had been changed and that more appropriate behaviour could be expected in future. Even if perceptions changed, there was not necessarily much that could be done with a different point of view. It did make a difference if a population yielded fewer recruits, sanctuaries, resources and intelligence to the enemy, but the key determinant of that was who actually was best placed 
to provide security and shape behaviour on the ground. These 'perception wars' were products of the material conditions they were supposed to shape.

This can be seen with the Russian experience of using disinformation as an instrument of strategy. Thus, in Ukraine, they did not wish to admit the role their forces were actually playing as this would have required acknowledging aggression. The pretence therefore was that the individuals concerned were volunteers or on holiday. When one of their anti-aircraft missiles shot down a Malaysia Airlines aircraft in July 2014, instead of accepting responsibility, they sought to suggest that it was the Ukrainians, with the claims becoming ever more fanciful. As this pattern of behaviour became apparent, Russian officials were not believed about anything, even when telling the truth. Russian propaganda played well in Russia but badly everywhere else, which had the effect of increasing Russia's sense of isolation but not of its influence.

The Russian strategy in Ukraine was characterised as a deliberate and skilful application of 'hybrid warfare'. This term gained currency after Israel was caught out during the Lebanon War of 2006 by the combination of guerrilla and conventional tactics adopted by Hezbollah. It came to refer to an approach drawing upon instruments from across the full spectrum, including terrorism, insurgency, criminality and conventional operations along with the extensive use of information operations. As an approach, this is not simple as it requires a formidable command structure to pull together these various instruments to achieve the greatest strategic effect. In practice, it might refer to a number of separate efforts set in motion at the same time that might or might not reinforce each other. In Ukraine, complex command arrangements complicated Russian attempts to control the situation on the ground while efforts at deception were by and large ineffectual as they became progressively transparent. One possible success was in projecting a more menacing image than Russia's actual strength warranted, which served to deter the West from escalating the conflict.

In practice, these forms of warfare acknowledged the limitations of the classical model in contemporary circumstances. Because of the difficulty of imagining a truly decisive military campaign under contemporary circumstances, it had been necessary to look for shortcuts and alternatives. Instead of the knockout blow in a decisive battle, various forms of force and coercion were used to reshape conflicts. Within these conflicts, the 
balance of advantage might shift one way or the other, but it was difficult to bring them to a conclusion. Success required exceptional circumstances when either the first moves were decisive because the defeated party had been caught napping or else because the participants were exhausted and there was a genuine basis for a political settlement.

The wars fought by Western countries in Afghanistan and Iraq turned out to be frustrating and inconclusive. The wars that were not fought, however, would have been much, much worse. One benign interpretation of all this is that the appreciation of the limits the classical model has extended the arena of deterrence. When it comes to war involving great powers, there is an argument that the cautions induced by nuclear deterrence now extend to conventional conflicts as well. It may be-as with Russia taking on Ukraine and Georgia but not Estonia and Latvia—that the unique dangers involved in any sort of major power are sufficient to reduce risk taking. This is why military action by those revisionist powers that do have grievances that they would like to address tend to be geared to probing, exploring the limits of acceptable behaviour rather than bold offensives designed to take a large opponent out action.

It is possible to frustrate, deflect, divert and distract opponents with a variety of forms of coercion, including economic sanctions, cyber attacks and some forms of deadly force, including seizures of disputed territory. None of this constitutes true victory. Has Putin won or lost in Ukraine or even in Syria? The fact that we can even have this debate indicates that the outcomes of war lack the clarity of the victories sought in the past, those with ceremonial surrenders and an enemy state at your mercy.

The challenge for the West in all of this is that wars have come to lack borders and endpoints. The idea of conflict as something contained in time and space, where there is a sharp demarcation between peace and war and between the civilian and military spheres, is consistently undermined. The classical model of warfare, of decisive campaigns, remains a beguiling ideal, but the real challenge for Western strategists is to come to terms with wars of continuing political struggle where military action ensuring a satisfactory political outcome have proved elusive. 



\title{
3 \\ Economics and security
}

\author{
Amy King
}

What is the relationship between economics and security, and how should strategists think about these two seemingly disparate areas of policy? Since the 1930s and 1940s, scholars such as Jacob Viner and E.H. Carr have recognised that economic and security aspects of policy-making ought to be studied in an integrated way. However, the economics-security nexus was traditionally neglected in Western International Relations and strategic studies scholarship. Michael Mastanduno suggests that in the early years of the Cold War, these fields became narrowly focused on military instruments of security at the expense of economic and other instruments of policy. This was partly due to the absence of direct economic contact between the United States and the Soviet Union and partly because the most important aspect of this bipolar system was nuclear deterrence and the potential for nuclear war. Whereas nuclear deterrence and other areas of military security and foreign policy were considered 'high' politics, economic matters were firmly relegated to the area of 'low' politics. ${ }^{2}$ By the 1970s, US international relations scholarship was characterised by the development of two prominent subfields-international political economy and security studies — and scholars working in these subfields

1 I am grateful to Andrew Kennedy and Satish Chand for helpful comments on an earlier draft of this chapter, and to the organisers of the conference 'SDSC at 50: New Directions in Strategic Thinking 2.0', where this chapter was first presented.

2 Michael Mastanduno, 'Economics and security in statecraft and scholarship', International Organization 52, no. 4, 1998, p. 836. 
asked different questions, used different methodological tools and typically published in different journals. As a result, the relationship between economics and security was systematically understudied within international relations. ${ }^{3}$ Outside the discipline of international relations, international economists were naturally focused on questions relating to the global economy but tended to be less interested in the 'political and strategic dimensions of international economic relations. ${ }^{4}$

Despite this neglect, there are of course several possible conceptual linkages that may be drawn between economics and security. At its most basic, economic growth allows government to devote greater resources to national defence expenditure and therefore economic wealth is the foundation of national military power. Traditionally, economic factors such as access to raw materials and technology, production of goods such as steel and iron, and a state's manufacturing capacity have all been considered important indices of national power. Economic growth also leads to growing demand for energy resources among states and therefore can become a source of international conflict between states as they compete for scarce resources. Conversely, economic decline can be a source of insecurity. States that are perceived to be in a position of decline may be more likely to take preventive military action in order to bolster their power position. Economics and security are also directly related because states may use economic sanctions and other economic instruments in their pursuit of wider strategic goals. Alternatively, states may use security policies to promote economic goals, such as by engaging in expansionist military behaviour to obtain access to territory or raw materials. ${ }^{5}$ Or, as work by Thomas Christensen on Maoist China has shown, states may use limited forms of military conflict to mobilise a domestic population towards the pursuit of major economic campaigns. ${ }^{6}$

Moreover, there is an increasingly extensive research agenda in international relations on the linkage between economic interdependence and security. Liberal internationalists, and the strand of commercial liberalism in particular, view trade, investment and other economic ties as a force for

3 Ibid., pp. 837-41.

4 Ibid., p. 836.

5 Brendan Taylor and Bruce Luckham, 'Economics and security', in Strategy and Security in the Asia Pacific, ed. Robert Ayson and Desmond Ball, Allen \& Unwin, Sydney, 2006, pp. 138-51.

6 Thomas J. Christensen, Useful Adversaries: Grand Strategy, Domestic Mobilization, and SinoAmerican Conflict, 1947-1958, Princeton University Press, Princeton, 1996, Chapter 6. 
peace between states. ${ }^{7}$ The self-interested pursuit of power by states can be mediated by economic interdependence, thereby offering 'the possibility of escaping ... a vicious cycle and finding new patterns of cooperation among states. ${ }^{8}$ At the most basic level is the view that, in an interdependent relationship, the potential loss of economic ties makes the cost of conflict between states so high as to act as a deterring factor. ${ }^{9}$ Polachek demonstrates that countries with significant trade relations are less likely to engage in conflict with one another owing to fear of the welfare losses that would arise from the breaking of trade relations. ${ }^{10}$ Not surprisingly, states that engage in the trade of strategic goods are thought to be especially deterred from conflict because of the higher welfare losses that arise from potential disruption to the supply of goods such as oil and other raw materials. ${ }^{11}$ Yet the connection between interdependence and cooperation does not only derive from states' concern for the welfare losses associated with conflict. Keohane views economic interdependence as a basis for institution-building between states, which can foster mechanisms for information sharing, trust-building and conflict resolution. ${ }^{12}$ In a parallel argument, Rosecrance suggests that trade is a superior method of the traditional military or imperialist means of acquiring products and markets in the international system. ${ }^{13}$ Furthermore, Gartzke, $\mathrm{Li}$ and Boehmer find that economic interdependence provides states with non-violent methods of signalling their intentions, thereby allowing states to display their resolve without the need for costly military conflicts. ${ }^{14}$ Finally, at the extreme end of the liberal view is the hypothesis that economic interdependence has led to the melting away of nation-state borders, thus reducing the relevance of state-based issues in a globalised or regionalised world. ${ }^{15}$

7 John R. Oneal, Frances Oneal, Zeev Maoz and Bruce Russett, 'The liberal peace: Interdependence, democracy, and international conflict, 1950-85', Journal of Peace Research 33, no. 1, 1996, p. 23; R. Rosecrance, The Rise of the Trading State: Commerce and Conquest in the Modern World, Basic Books, New York, 1986, pp. 24-5.

8 Rosecrance, The Rise of the Trading State, p. ix.

9 John R. Oneal and Bruce Russett, 'The Kantian peace: The Pacific benefits of democracy, interdependence, and international organizations, 1885-1992', World Politics 52, no. 1, 1999, p. 3.

10 Solomon William Polachek, 'Conflict and trade', Journal of Conflict Resolution 24, no. 1, 1980, p. 57.

11 Ibid., pp. 67-71.

12 Robert O. Keohane, 'International liberalism reconsidered', in The Economic Limits to Modern Politics, ed. John Dunn, Cambridge University Press, Cambridge, 1990.

13 Rosecrance, The Rise of the Trading State, pp. 30-9.

14 Erik Gartzke, Quan Li and Charles Boehmer, 'Investing in the peace: Economic interdependence and international conflict', International Organization 55, no. 2, 2001, pp. 418-19.

15 Kenichi Ohmae, The End of the Nation State: The Rise of Regional Economies, Free Press Paperbacks, New York, 1995. 
To realists, this liberal view of the world is misguided. Buzan challenges the relationship between economic interdependence and peace by arguing that the 'long peace' that has existed since 1945 is due to the presence of nuclear deterrence and the structural stability associated with an international system of bipolarity, rather than economic interdependence. ${ }^{16}$ Furthermore, although observers have been forced to accept the presence of high economic interdependence in the Asia Pacific in particular, Morrison questions whether this interdependence has been sufficient to alter states' competitive behaviour. ${ }^{17}$ To realists, economic interests will always remain subordinate to military ones for:

so long as countries have reason to fear the recurrence of war, no emphasis on the economic benefits of international trade will induce them to forego such a measure of economic self-sufficiency as their Governments consider feasible and desirable for their military security. ${ }^{18}$

In fact, realists further extend these concerns and argue that economic interdependence may even become a source of conflict between states. In contrast to the liberal view that interdependence promotes informationsharing and mutual respect between states, Kenneth Waltz argued that the closer contact and greater range of potentially competitive issues brought about by interdependence raises the likelihood of conflict. ${ }^{19}$ Economic interdependence may also be a source of conflict if the costs and benefits of the interdependent relationship are not symmetrically distributed. If states' dependence on one another is not evenly balanced, asymmetric interdependence can be exploited as a source of power, thereby eroding the peaceful outcomes of interdependence. ${ }^{20}$ Doran speaks of the 'gloved hand' of power concealed by an asymmetric relationship in which smaller states are subject to the paternalism of those more dominant. ${ }^{21}$

16 Barry Buzan, 'Economic structure and international security: The limits of the liberal case', International Organization 38, no. 4, 1984, pp. 605-7.

17 Charles E. Morrison, 'Interdependence, policy networks, and security in Asia Pacific', in AsiaPacific Security: The Economics-Politics Nexus, ed. Stuart Harris and Andrew Mack, Allen \& Unwin, Sydney, 1997, p. 123.

18 Heinz Arndt, 1944, quoted in Robert Gilpin, 'Economic interdependence and national security in historical perspective', in Economic Issues and National Security, ed. Klauss Knorr and Frank N. Trager, Regents Press of Kansas for the National Security Education Program, Lawrence, 1977, p. 52. 19 Kenneth N. Waltz, 'The myth of national interdependence', in The International Corporation, ed. Charles E. Kindleberger, MIT Press, Cambridge, MA, 1970, p. 205.

20 Robert O. Keohane and Joseph S. Nye, Power and Interdependence, Little, Brown \& Company, Boston and Toronto, 1977, p. 11; Albert O. Hirschman, National Power and the Structure of Foreign Trade, University of California Press, Berkeley and Los Angeles, 1945, p. 15.

21 Charles F. Doran, 'Living with asymmetry', Mershon International Studies Review 38, no. 2, 1994 , p. 260. 
Essentially, while an asymmetric relationship might not necessarily lead to conflict between states, 'the existence and abuse of unequal power within asymmetrical relations creates a predisposition for conflict that is greater than that found in symmetrical trade relations'. ${ }^{22}$

The view that asymmetry could become a source of conflict stems from the neorealist concern for relative gains or losses in power between states, rather than absolute gains or losses. States' concern for this relative distribution of power-who will gain more?-is the result of existing in an anarchical international system. ${ }^{23}$ As Mastanduno explains, 'Anarchy breeds fear and distrust, leading nation-states to worry, at the extreme, that they will be conquered or destroyed by their more powerful counterparts'. ${ }^{24}$ Because economic power is a particularly fungible form of power, economic gains could be easily transferred into military ones. Indeed, gains from trade create economic efficiencies, potentially freeing resources for increased military spending. In economic terms, this is referred to as a security externality. While trade between allied states can create a positive externality in the form of greater military spending and shared security for both, trade with an adversary also leads to greater military spending and therefore a decline in the security position of one state relative to another. ${ }^{25}$

Since the end of the Cold War, considerable intellectual effort has been expended in wading through these competing claims to determine whether economic interdependence is a force for peace or a source of conflict between states. ${ }^{26}$ Yet, in many cases, the underlying debate between realists and liberals

22 Katherine Barbieri, 'Economic interdependence: A path to peace or a source of interstate conflict?', Journal of Peace Research 33, no. 1, 1996, p. 32.

23 Joseph M. Grieco, 'Anarchy and the limits of cooperation: A realist critique of the newest liberal institutionalism', International Organization 42, no. 3, 1988, p. 500.

24 Michael Mastanduno, 'Do relative gains matter? America's response to Japanese industrial policy', International Security 16, no. 1, 1991, p. 78.

25 Joanne Gowa and Edward D. Mansfield, 'Power politics and international trade', American Political Science Review 87, no. 2, 1993, pp. 408-10.

26 See Barbieri, 'Economic interdependence'; Gowa and Mansfield, 'Power politics and international trade'; Jean-Marc F. Blanchard, Edward D. Mansfield and Norrin M. Ripsman, Power and the Purse: Economic Statecraft, Interdependence, and National Security, Frank Cass, London, 2000; Gartzke, Li and Boehmer, 'Investing in the peace'; Scott L. Kastner, 'Does economic integration across the Taiwan Strait make military conflict less likely?', Journal of East Asian Studies 6, 2006; Edward D. Mansfield and Jon C. Pevehouse, 'Trade blocs, trade flows, and international conflict', International Organization 54, no. 4, 2000; Brian M. Pollins, 'Does trade still follow the flag?', American Political Science Review 83, no. 2, 1989; Richard Rosecrance, 'Economics and national security: The evolutionary process', in Asia-Pacific Security: The Economics-Politics Nexus, ed. Stuart Harris and Andrew Mack, Allen \& Unwin, Sydney, 1997. 
remains unresolved. ${ }^{27}$ Two recent edited volumes by T.J. Pempel and Avery Goldstein and Edward Mansfield have further contributed to these debates by examining the economics-security nexus within the context of East and North-East Asia in particular. ${ }^{28}$ These volumes contain new empirical evidence about the economic implications of maritime disputes, the role of energy insecurity and the relationship between economics, security and technology in East Asia. But, as Evelyn Goh's recent review of these works points out, these two volumes are emblematic of an ongoing shortcoming in much of the existing literature on economics and security - that is, these works 'treat the liberal assumption that economic interdependence leads to security, implicitly or explicitly, as the leading theory to prove or disprove'. ${ }^{29}$ They therefore expend most of their intellectual energy trying to determine whether economic or security factors are the key independent variable explaining the outcome of peace or conflict. As Goh and the editors of these volumes themselves note, there is still no consensus on the answer to this question; it is possible to find evidence that supports either explanation. It is precisely for this reason that the debate continues to rage between realists and liberals, between pessimists and optimists, and between those who focus on security-driven explanations and those who focus on economicsdriven explanations.

More importantly, though, many of these traditional approaches to studying the relationship between economics and security do not capture empirical reality, particularly in Asia where the nexus between economic and security factors is related in much more interesting and diverse ways. The China-Japan relationship, for instance, is emblematic of a relationship that has been shaped consistently by both extensive economic ties and considerable political and security tensions. Indeed, tense political-security relations and thriving economic relations between China and Japan are not a contradiction but rather two sides of the same coin. After World War II, Japan's industrial capabilities made Japan not only a model of a modern and powerful nation and an important source of industrial goods and expertise for Communist China, but also a latent

27 For an excellent overview of this literature, see Christina Davis, 'Linkage diplomacy: Economic and security bargaining in the Anglo-Japanese alliance, 1902-23', International Security 33, no. 3, 2008-09, pp. 147-9.

28 Avery Goldstein and Edward D. Mansfield (eds), The Nexus of Economics, Security, and International Relations in East Asia, Stanford University Press, Stanford, 2012; T.J. Pempel (ed.), The Economic-Security Nexus in Northeast Asia, Routledge, New York, 2013.

29 Evelyn Goh, 'Making headway on the 'economic-security nexus': Contributions from SouthEast Asia', Asan Forum 1, no. 3, 2013. 
military threat to China. These dual conceptions of Japan have shaped Chinese thinking since the late 19th century and continued to pervade the thinking of the Chinese Communist Party after 1949. Crucially, the existence of these dual conceptions poses a challenge to both the liberal thesis that economic ties must necessarily breed closer political and security relations and the realist contention that close political and security ties are a prerequisite for economic interdependence. Instead, the ChinaJapan relationship demonstrates that insecurity can motivate economic engagement. Between 1949 and 1971, Chinese officials sought economic engagement with Japan because of a profound sense of insecurity about China's low levels of industrial development and limited ability to win modern, industrialised wars. It was precisely because Japan served as a latent threat to China that Chinese officials looked to Japan for advice, goods and technology about how to 'catch up' and become a modern, industrialised and powerful state. ${ }^{30}$

In addition, these existing approaches often fail to capture the importance of domestic factors in understanding the nexus between economics and security. For example, in his new book on Asian security, Robert Ayson writes about the uneven effects of economic transformation occurring within China, where coastal fringes are developing much faster than inner provinces. This has a major impact on domestic security (often resulting in protests by state-owned company employees) and has undermined the legitimacy of Communist Party rule and a strengthening of the state's internal security apparatus. Equally, in India, uneven economic development is an important driver of internal violence. ${ }^{31}$ Christina Davis's work on the relationship between alliances and economics also highlights the need to better understand domestic drivers of economic and security policymaking. Much of the early literature on alliances and economics argued definitively that countries with military alliances were much more likely to enjoy strong trade and investment ties. Yet Davis's research on the AngloJapanese alliance of the early 1900s demonstrates that alliances might not necessarily lead to larger or more favourable economic relations between two states. This is because when a state offers special investment rights, unilateral

30 Amy King, China-Japan Relations after World War Two: Empire, Industry and War, 1949-1971, Cambridge University Press, Cambridge, 2016. In fact, the ongoing combination of political-security tensions and close trade and investment ties in the China-Japan relationship continues to motivate new findings on the economics-security nexus, as an important recent study demonstrates: Christina L. Davis and Sophie Meunier, 'Business as usual? Economic responses to political tensions', American Journal of Political Science, 55, no. 3, 2011, pp. 628-46.

31 Robert Ayson, Asia's Security, Palgrave, London, 2015, pp. 98-9. 
trade liberalisation or other preferential economic treatment to an ally, it faces domestic opposition from business groups whose interests might be harmed by the proposed economic deal. ${ }^{32}$ In these cases, domestic business groups will place political pressure on their government to impose higher tariffs and export quotas to protect their market share. Consequently, a state might pursue economic policies that actually harm the economic interests of its ally in order to meet the demands of domestic business interests.

The role of domestic factors continues to be vitally important in understanding the economic-security nexus in the contemporary AsiaPacific region. For example, the Australia, New Zealand, United States (ANZUS) alliance demonstrates how domestic interest groups in both countries have successfully lobbied for economic policies that have harmed the economic interests of the allied partner state. In the 1960s and 1970s, the staunch protectionism of Australia's agricultural, textiles and manufacturing sectors led to significant Australian discrimination against US exports and frequent trade disputes between the two countries. In the 1980s, the United States retreated from the liberalisation agenda being pursued by Australia and instead erected trade barriers and signed preferential trade agreements that were fundamentally harmful to Australia's economic interests in Asia. In the 2000s, the two countries were motivated by foreign policy and security objectives to develop a bilateral preferential trade agreement: the Australia-United States Free Trade Agreement. Yet the agreement that was ultimately signed was detrimental to the Australian agricultural sector and consumers of intellectual property. ${ }^{33}$ Working in the opposite direction, Miles Kahler and Scott Kastner's work on the China-Taiwan relationship has shown that crossStrait economic ties have had a transformative effect on domestic politics in Taiwan. In particular, the growing cross-Strait economic relationship in the 1990s and early 2000s led to the emergence of strong political constituencies in Taiwan that opposed Taiwanese independence or other foreign and security policy moves that could endanger Taiwan's economic

32 Davis, 'Linkage diplomacy'.

33 Amy King, 'Economic links between Australia and the United States', in Australia's American Alliance: Towards a New Era?, ed. Peter Dean, Stephan Fruehling and Brendan Taylor, Melbourne University Press, Melbourne, 2016, pp. 98-118. 
relationship with mainland China. ${ }^{34}$ How these economic factors affect Taiwanese domestic politics and the cross-Strait relationship under the administration of President Tsai Ing-wen, who came to power in 2016, will be a rich area for future research.

These and other examples serve to highlight the need to find new ways to understand the nexus between economics and security. Moreover, the examples suggest that there is nothing innate or predetermined about the relationship between economics and security; an important first step for researchers is to better understand how states actually conceptualise this relationship. One way to achieve this is to explore critical junctures: key historical moments when countries' thinking about the relationship between economics and security has evolved in important directions. In the United States, the experience of World Wars I and II was powerful in shaping government officials' understanding of the economics-security nexus. Robert Pollard argues that US officials became 'preoccupied' with the security implications of foreign economic policy in the 1940s because they had seen how economic nationalism, closed economic blocs and national depressions had led to major conflict in Europe and Asia; and how states had used economic sanctions, currency manipulation and blockades as weapons of war. ${ }^{35}$ Subsequently, in the wake of World War II, the Truman Administration pursued the goal of 'economic security', a concept that, in their eyes, meant to 'create an open world economic order that would serve US strategic purposes' by preventing the recurrence of dangerous economic nationalism, depression and war. ${ }^{36}$ The US goal was to create an open economic order that would ensure freedom of the seas, free trade, equal access to raw materials and international collaboration in the economic realm.

In Japan, the concept of 'economic security' also evolved in a similar era, as Japanese military officers and political officials observed the defeat of Germany-the superior military power-in World War I. As Michael Barnhart has shown, Japan's search for economic security in the wake of World War I stemmed from the belief that:

34 M. Kahler and Scott L. Kastner, 'Strategic uses of economic interdependence: Engagement policies on the Korean Peninsula and across the Taiwan Strait', Journal of Peace Research 43, no. 5, 2006, pp. 523-41.

35 Robert A. Pollard, Economic Security and the Origins of the Cold War, 1945-1950, Columbia University Press, New York, 1985, pp. 4-5.

36 Ibid., p. 2. 
Future wars would be fought not only with guns but with the entire resources of nations, from engineers to doctors, from cotton to iron ore. Without these requisites of economic security, the mightiest army would be paralyzed. And without a modern industrial base that could be mobilized in time of need, even these requisites would prove useless. A nation that could not supply all of its own needs in wartime, a nation that was vulnerable to economic pressure from other nations, would be neither truly secure nor truly sovereign. ${ }^{37}$

These views about the importance of self-sufficiency, particularly in relation to strategic goods, prompted Japan's imperial reach into North and South-East Asia during the 1920s and 1930s. For Japan, a resourcepoor nation, the goal of economic self-reliance could only be achieved through imperialism. Thus, building on its existing colonies in Formosa (Taiwan) and Korea, Japan colonised the major new territory of Manchuria (North-East China). These colonies provided access to raw materials such as coal, iron ore and soy bean; opened up new export markets for Japanese products; and allowed Japan to build major light and heavy industrial sectors that could fuel Japan's war machine. ${ }^{38}$ Japan's imperial expansion and pursuit of economic autarky would ultimately draw it into outright war with China and later with the United States. The disastrous consequences of Japan's search for 'economic security' meant that, after their country's defeat in World War II, Japan's leaders were required to come up with a new approach to securing Japan and gaining access to badly needed raw materials and export markets. One outcome of this was the development in the 1970s and 1980s of a new concept of 'comprehensive security' (sōgo anzen hoshō), which acknowledged Japan's dependence on the external world for access to resources, markets and security. ${ }^{39}$ Japan's post-war concept of comprehensive security rested on the premise that Japanese security could not be grasped in terms of isolated notions of military, economic and political security; rather, these separate factors were 'interactive indexes of Japan's national power'. ${ }^{40}$ Because of these experiences of war and defeat, the Japanese understanding of the

37 Michael A. Barnhart, Japan Prepares for Total War: The Search for Economic Security, 1919-1941, Cornell University Press, Ithaca and London, 1987, p. 18 (emphasis in original).

38 Ibid., Chapter 1.

39 J.W.M. Chapman, Reinhard Drifte and I.T.M. Gow, Japan's Quest for Comprehensive Security: Defence, Diplomacy, Dependence, Frances Pinter Publishers, London, 1983, p. xvii; Y. Soeya, 'Japan: Normative constraints versus structural imperatives', in Asian Security Practice: Material and Ideational Influences, ed. M. Alagappa, Stanford University Press, Stanford, 1998, pp. 216-17.

40 M.G. L'Estrange, The Internationalization of Japan's Security Policy: Challenges and Dilemmas for a Reluctant Power, Policy Papers in International Affairs 36, Institute of International Studies, University of California, Berkeley, 1990, p. 16. 
relationship between economics and security is centred around the notion that economic strength cannot be separated from national or military strength; the two are directly correlated. ${ }^{41}$

Beyond critical junctures, researchers at the Strategic \& Defence Studies Centre (SDSC) continue to explore the intersection between economics and security in Asia, a research program that builds upon a distinguished history of scholarship by academics including Stuart Harris, Desmond Ball and Brendan Taylor. In October 2015, the Centre hosted a major workshop entitled 'Unpacking the economics-security nexus in Asia: New concepts, questions and research approaches. The workshop brought together scholars from around Australia who are engaged in innovative research and using new concepts, methods and case studies to interrogate the relationship between economics and security. Participants in the workshop drew on a wide range of concepts and methodological approaches, including geo-economics and geopolitics, economic nationalism, economic sanctions, strategic geography and foreign policy analysis and case studies ranging from Indonesian resource nationalism, Chinese economic statecraft, oil and economic coercion and the securitisation of finance.

Not surprisingly, a number of workshop papers focused on China and interrogated Chinese economic statecraft, its connectivity projects and technological innovation and the strategic implications of its economic rise. For example, Darren Lim at The Australian National University (ANU) is investigating the conditions under which China might use economic interdependence as an instrument to coerce other states, noting that there is strong variation in the occasions on which China has been able to exert pressure on trading partners. Lim's research importantly recognises the need to develop new measures of dependence and coercion because existing measures of dependence assume 20th-century conditions and therefore fail to view trade as part of a complex production network. In addition, Evelyn Goh is examining China’s infrastructure-building drive across mainland South-East Asia, South Asia and Central Asia since the late 1990s. While this aspect of China's periphery strategy has garnered increasing attention because of the highly publicised 'Belt and Road Initiative' 42 (BRI) under President Xi Jinping, Goh argues that

41 Reinhard Drifte, Japan's Security Relations with China since 1989: From Balancing to Bandwagoning?, Routledge Curzon, London, 2003, p. 2.

42 'Belt and Road' is also known as 'One Belt, One Road'. 
BRI is but one element of a wider strategy designed to deal with China's periphery and the outside world, which contains renewed geographical and geopolitical elements. Drawing on her background as a geographer, Goh is exploring how China is reviving an older tradition of geo-strategy as a result of numerous push-and-pull factors, including the constraints on China's ambitions in maritime Asia and the need to tackle problems like energy security and insurgencies at its western peripheries. ${ }^{43}$

Another major focus of the workshop was how to analyse the complex linkages between the domestic and the international levels while simultaneously unpacking the economics-security nexus. One scholar doing just this is Andrew Kennedy, based at ANU, whose research examines the role of technology and innovation in shaping the relationship between the United States and rising powers such as India and China. Kennedy notes that the world's most powerful state, the United States, is locked in a technological embrace with two rising competitors-China and India-despite theoretical predictions that the United States should distrust and shun collaboration with these rival powers. Yet the pattern of US technological collaboration with China and India is inconsistent. The United States remains a highly welcoming destination for foreign graduate students but has also placed limits on the migration of skilled labour and has not increased the number of skilled workers coming into the country since 2004. To explain this variation, Kennedy argues, we need to understand the role of subnational actors, such as research and development (R\&D)-intensive firms and research universities and the lobbying role they play in US domestic politics. These actors have a natural openness to skilled labour and, to the extent that they can ward off political opposition, play a powerful role in lobbying the federal government on migration policies. ${ }^{44}$

So what does all this mean for the field of strategic studies? First, it is vital that we do not return to the drift of the 1970s, when economics and security occupied increasingly separate realms. Strategists must pay closer attention to the myriad ways in which economic factors affect security outcomes, and the economic drivers underpinning some of the

43 For more on these projects, see Amy King and Evelyn Goh, 'Unpacking the economic-security nexus in Asia: New Concepts, Questions and Research Approaches', Workshop Report, ANU Research School of Asia and the Pacific, 1 October 2015; sdsc.bellschool.anu.edu.au/sites/default/files/ uploads/2016-07/2015_12_15_economic-security_nexus_asia_web.pdf (retrieved 20 January 2018). 44 Ibid. See also Andrew Kennedy, 'Unequal partners: US collaboration with China and India in research and development', Political Science Quarterly 132, no. 1, 2017, pp. 63-86. 
key strategic challenges of our age: resource insecurity, trade 'wars' and economic influence and coercion. Second, we must be clear that we cannot take an either/or approach to studying economics and security. Both sets of factors will shape Asia's future and the relationships between states in this region. It is therefore imperative that scholars find new and better ways of unpacking the connections between economics and security rather than assuming that one or the other will predominate. Third, as we deepen our research into the economics-security nexus, it is imperative that strategists consider the changes that have occurred in the global economy over the past half-century. Today, foreign direct investment, skilled migration and global value chains comprise increasingly important dimensions of the ways in which states interact in the world economy, yet the literature has failed to keep pace and tends to remain narrowly focused on trade. ${ }^{45}$ Research that focuses on the security implications of these newer forms of economic interdependence is badly needed. Finally, recent trends in research in this field have demonstrated the vital importance of opening up the 'black box' of the state to understand how domestic factors affect the relationship between economics and security. And here, a field such as strategic studies is particularly well placed to consider the domestic level given its long-standing focus on how domestic factors shape decisionmaking during moments of crisis. ${ }^{46}$ Economics and security factors are intimately connected in state policy-making. It is time for strategic studies to incorporate economics once more.

45 Some recent exceptions include Darren J. Lim and Rohan Mukherjee, 'What money can't buy: The security externalities of Chinese economic statecraft in post-war Sri Lanka', Asian Security, 28 December 2017; Andrew Kennedy, The Conflicted Superpower: America's Collaboration with China and India in Global Innovation, Columbia University Press, New York, 2018; John Ravenhill, 'Production networks and Asia's international relations', in Oxford Handbook of the International Relations of Asia, ed. Saadia Pekkanen, John Ravenhill and Rosemary Foot, Oxford University Press, Oxford, 2014, pp. 348-68.

46 Graham Allison and Philip Zelikow, Essence of Decision, 2nd edn, Addison-Wesley, New York, 1999; Stephen D. Krasner, 'Are bureaucracies important? Or Allison Wonderland', Foreign Policy, no. 7, 1972, pp. 159-79; Jutta Weldes, 'Constructing national interests', European Journal of International Relations 2, no. 3, 1996, pp. 275-318. 



\title{
4 \\ A bias for action? The military as an element of national power
}

\author{
John J. Frewen
}

Australia's military instils in its members a 'can-do' culture with a bias for action, inculcated early in the careers of virtually all officers and enlisted personnel. This ethos seeks both to ensure that opportunities are seized and to avoid the more common historical peril of inaction. This instinct serves us well on the battlefield; it can be be of less benefit at the operational and strategic levels where consequences of decisions tend to be more farreaching. This bias is not merely a military concern. The public can also demonstrate a bias for action without due consideration of the broader political issues at stake. Depending on the circumstances, politicians can also demonstrate bias for either action or perceived action. Regardless, the Australian Defence Force (ADF) is a relatively well-resourced and capable asset available to governments for a broad range of contingencies. From high-intensity warfighting to humanitarian operations, the ADF can be rapidly brought to bear to satisfy the ends of policy-uniquely in our government, through the employment of armed force. Yet, while the ADF can contribute to Australia's national security, it cannot alone deliver national prosperity.

Realising a nation's potential requires considered thought about how to best utilise all the assets at its disposal. This is most readily achieved with a clear view of the nation's highest aims and a strong sense of the risks and costs that can be accepted in their pursuit. Strategy—-the art of aligning 
ends, ways and means-is the surest path for defining those conditions. The use of military force entails profound risks, including the potentially pointless loss of life. This risk tends to be more acute if military elements are used in isolation from other instruments at the nation's disposal. Nevertheless, a bias for military action remains evident in both the military and government even if the underlying motivations sometimes differ. This chapter explores the implications of a bias for military action on the making of strategy in Australia and on the military as an institution and important element of national power.

The making of effective strategy is one of the most complex and difficult aspects of government work. And although there are many capacities within government to develop strategic policy, it is important not to confuse policy with strategy. Policy is a statement of principles intended to guide actions. Strategic policy requires strategies to harness national instruments of power in the service of political objectives. In general, the best strategies are those that integrate all the elements of national power: the diplomatic, information, military, economic (DIME). ${ }^{1}$ These elements can be prioritised differently depending on the circumstances, but integration is usually key to achieving the best effect, especially in complex endeavours.

\section{Who does strategy?}

In the Australian Government, and arguably in most comparable Western democratic bureaucracies, there is a stark contrast between the large number of people whose job involves contributing to the making of strategy and the relative absence of government bodies dedicated to formulating strategy as a whole. This is problematic because it disaggregates the strategy-making process to such an extent that it precludes the level of coherence needed to be effective.

While the Department of Prime Minister and Cabinet is meant to provide direction, no single entity within the Australian Government is presently tasked to routinely deliver national strategies that integrate all elements of national power. Extant government agencies and departments are geared to delivering policies or assessments. Policies are routinely well agreed and

1 An alternative national power model to DIME also includes financial, intelligence and law enforcement (DIMEFIL). 
aligned across departments before consideration by the political executive, but only extraordinary circumstances drive governments to deliver national strategies that bridge the gap between policy and outcomes. Actual strategy clearly defines the political imperative (ends), parameters for action (ways) and the resources that may be utilised or expended (means). Unfortunately, for Australia, our strategic culture has long relied on a powerful ally to set overarching grand strategy, which denudes the capacity for coherent or sensible formulation of strategy here at home.

Other systemic issues stymie the long-term thinking and planning required for strategy as well. Our federal three-year electoral cycle, the 24-hour news cycle and a growth in populist politics lead us towards short-termism in policy. Similarly, our key decision-making bodies, including federal parliament and the National Security Committee of Cabinet (NSC), by their natures also have a proclivity for near-term-if not immediate- resolution of matters without the consistent setting of clear national aims or ideas about the integration of separate elements of national power. The resultant processes create systemic myopia in which government scrambles from one issue to the next, typically without prolonged consideration. For example, rarely does government pause to consider alternative scenarios to contest the wisdom of certain chosen courses or pay due consideration to the inevitable action/reaction cycles of complex strategic decisions.

This is not to say that Australia cannot make strategy at all. One example is the implementation of Operation Sovereign Borders (OSB) to cease the unauthorised arrival of people to Australia by boat. Regardless of whether one agrees with the morality of the approach, OSB provides an example where political will is married with a comprehensive integration of a wide range of national instruments to produce a successful political effect. ${ }^{2}$ This is an example of national strategy delivering sustained political objectives against an adaptive adversary. However, it is a rare example and far more the exception than the rule.

2 Operation Sovereign Borders (OSB) employs diplomatic, intelligence, informational, law enforcement, economic, maritime and defence effects. All are individually crucial but are also interdependent on the other elements for success. 
At the other end of the spectrum, the UK's Chilcot Report ${ }^{3}$ provides a timely counterexample of military forces being employed in costly and uncoordinated ways. The report paints a disturbing picture of military commitments almost devoid of a coherent national strategic narrative.

\section{The rush to action}

The use of military power is problematic in a political environment that routinely privileges quick outcomes. Military forces can be employed overtly and almost immediately in pursuit of political ends. Because of the ready utility of armed forces, many forms of military action can be taken quickly — even in the absence of a fully developed strategy. The ADF can, at times, be used as a force of convenience rather than a force of necessity. This can be appropriate and successful in the resolution of small-scale emergencies, such as rescues or evacuations, but can also find nations mired in increasingly costly financial and mortal endeavours in situations that elude straightforward resolution or extraction. ${ }^{4}$ The ready availability of military forces, coupled with a can-do military culture, and politicians eager for quick responses can see military forces too easily deployed with military practitioners and politicians equally complicit.

Senior military officers are enthusiastic about demonstrating the utility and quality of Defence capabilities and are justifiably proud to see the men and women of the ADF succeed in difficult circumstances. However, their enthusiasm is diminished when operations are not supported by appropriate national strategies. Frustrations arise at the tactical level when strategic directives lack clear political objectives or a tangible military end state. Military concerns are compounded if political risk aversion also leads to impractical constraints on military operations (such as excessive restrictions on the employment of national assets within a coalition or a stipulation that there be no casualties). Military resolve is most challenged when an inappropriate level of resourcing for operations or

3 United Kingdom Cabinet Office, The Report of the Iraq Inquiry [Chilcot Report], 6 July 2016, www.gov.uk/government/publications/the-report-of-the-iraq-inquiry (retrieved 16 January 2018).

4 The American war in Vietnam is an example of primarily military action being commenced for initially limited aims before a doubling-down effect took hold to justify expenditure and losses and avoid a loss of national prestige. 
a lack of commitment to achieving military victory risks lives without strong purpose. In recent decades, many now-senior officers have experienced each of these problems.

The ADF maintains a broad range of platforms and capabilities. These forces are highly responsive and willing, and have a planning culture that supports rapid employment. These combine to make the ADF one of the government's instruments of first resort. Military forces present political leaders with rapid and tangible means to display resolve. A political bias for action becomes problematic when military capabilities are not effectively orchestrated with the other elements of national power, when the opportunity costs of utilising military assets rather than civilian assets are not considered, or when military personnel and equipment are either required to use force or are put at risk when some other national instrument could achieve the same effect. That no single entity in government is tasked to evaluate the relative merits of national assets or to ensure such integration via the development of overarching national strategies means that Australian military forces risk being deployed in suboptimal ways.

\section{Parameters of force}

The employment of military force should always be subordinate to policy, itself embedded in a firm conception of the national interest. What national interest is to be served? Is the use of military assets optional or vital (such as in the face of an existential threat)? Is the use of force necessary for the achievement of the task? Is the intended effect symbolic or substantive? Will we be acting unilaterally, be leading a coalition or be junior partners within a coalition? If in a coalition, will our military contribution be proportionate? What degree of integration will there be with other agencies? Do we understand the consequences and likely effects of the use of military forces? What is our tolerance for risk in relation to our forces and platforms? To complicate matters further, moreover, these considerations can change during an operation. For example, force might be required early in a mission but not later on. While these considerations do illustrate the complexity of military operations, and may temper the rush to use force, they cannot altogether ensure that decisions to employ military forces will be free of bias. 
The risks inherent in military commitments tend to be lower in the absence of an armed adversary. For example, the recent Operation Fiji Assist 2016-a humanitarian task with no requirement for use of forcesaw military forces acting in concert with the Department of Foreign Affairs and Trade (DFAT) and New Zealand counterparts. Together, they quickly helped facilitate relief for the people of Fiji in response to the havoc wreaked by Tropical Cyclone Winston. The ADF also very effectively acted as ambassador for Australia and were subsequently extracted in a timely and appropriate way after having reinforced Australia's standing in the region.

In 2003, the Regional Assistance Mission to Solomon Islands (RAMSI) similarly saw ADF forces supporting DFAT and the Australian Federal Police (AFP) in security operations to restore law and order during troubled times that included confronting potentially dangerous armed opponents. RAMSI demonstrated effective integration of the elements of Australia's national power to avoid the emergence of a regional failed state. Australia's efforts again enhanced the country's reputation as a good neighbour and partner in the Pacific despite achievement of strategic objectives proving costlier in time and dollars than was originally anticipated. Arguably, our commitments in both Solomon Islands and Fiji were not optional or discretionary but central to our longer-term regional interests. Conversely, the benefits of our recent deployments into war zones have been less apparent.

Australian operations in Iraq in 1990-91 and since 2002 in Afghanistan can be argued as discretionary operations in which alliance considerations outweighed any threats to Australia's direct interests. In these cases, ADF forces (other than special forces) were largely confined to limited combat operations designed to minimise the likelihood of casualties and avoid circumstances that might restrict Australia's ability to extract forces at the time of its choosing. Although force was a necessary component of these missions, it was not required to attain Australia's preferred policy outcomes, nor was it essential to achieving military victory. Indeed, what exactly constituted 'military victory' was not well defined and was left largely in the hands of US or North Atlantic Treaty Organization (NATO) mission heads. In these cases, military force was employed more to support the US alliance, and thereby sharpen an instrument in Australia's national security toolbox, than in direct defence of any vital 
national interest. Notwithstanding the importance of the US alliance for Australia, in both these cases military efforts were not consistently well integrated with other elements of national power.

To focus on the case of Afghanistan, the ADF-led Australian efforts to establish security, develop civilian capacity and support local governance in Oruzgan Province. Supported by DFAT, AFP efforts focused on counter-drug operations despite the lack of an effective local Afghan police force or a viable program to develop such a capability. Australian on-theground commitments were in consequence not in keeping with strategic objectives. ADF operations did contribute to denying insurgents a safe haven more broadly (as do our ongoing efforts). Yet more than a decade later it is difficult to portray a compelling case that the country's efforts have provided an enduring effect.

The most enduring aspect of Australian commitments in both Afghanistan and Iraq is the affirmation of a commitment to our major ally in matters of global concern and of our support to troubled nations in times of crisis. Australian military presence was arguably more significant in an alliance sense than was any combat success or nation-building outcome they achieved. Australia's military efforts in Iraq and Afghanistan reinforced our reputation as a good global citizen, one committed to a rules-based world order. Yet actions in both countries lacked a strategy effective in integrating Australia's broader government commitments for achieving anything beyond 'showing the flag'. Perhaps, however, no strategy was needed given that mere presence was sufficient to achieve the strategic objective of reinforcing the Australia-US relationship.

\section{Policy conundrums}

This modern phenomenon, whereby the deployment of military forces can be the policy outcome itself, presents four conundrums. The first is that this style of employment of military force belies the traditional model of strategy as a bridge that links means with ends. This seems more like using means to secure other means. The second is that strategic policy is increasingly supplanting national strategy with implications that are not well understood. Third, military force is being used in isolation from other elements of national power, which rarely delivers sustainable outcomes. Finally, military personnel are at risk of being killed or wounded to bring about policy goals that could be achieved in other, less risky ways. 
As mentioned, the Australian Government is currently geared to formulate strategic policy, but not strategy per se. We are a policy-led bureaucracy in which the coin-in-trade is position papers and assessments presenting options to government. Strategic policy discussions and papers typically touch on principles for endorsement, recommended diplomatic stances, possible actions or responses in a broad sense, and discussion of risks and the ways they might be mitigated. These are often enough for guiding the routine relationships and business of government in a set-and-forget manner, but they are not sufficient for managing situations where some vital national interest is genuinely threatened. This is where policy falls short of strategy in defining the interrelationship of ends, ways and means, and where policy-makers fall short of the requirement for strategists to make plans in an interactive and competitive context. The dominance of strategic policy over strategy is also how we also continue to risk a 'rush to action' that favours rapid and highly visible military commitments without fully defined, longer-term national aims or integration with other elements of national power.

In a crisis, doing something is often seen as a common imperative. The high-readiness of military assets makes them available early in any crisis, but there are other reasons that government tends to reach for the military first. Military units and formations are structured to operate and sustain themselves independently if necessary. They are also trained to operate with restrictions, limitations and caveats on their authorities and activities - and have a culture that anticipates constant shifts in guidance. Government decisions can be quickly turned into orders and military forces moved out. Other elements of national power are rarely as responsive. Diplomatic agreements must be negotiated and coordinated. Informational activities can have immediate effects but can also require broad consultation and careful timing in ways that preclude immediacy. Economic or fiscal measures require agreement and can have unpredictable (and often delayed) effects. If being seen to take timely action is a priority, the military is the instrument of national power that can act before other elements of national power are effectively brought to bear. However, the non-integrated use of military force rarely delivers sound long-term solutions to a crisis.

The example of RAMSI demonstrates a comprehensive whole-ofgovernment attempt to restore security, law and order, good governance, a functioning justice sector and sustainable economy concurrently to a failing nation. After a decade, RAMSI has delivered sound results and has 
Solomon Islands once again effectively managing its own destiny, albeit with some way still to go. In Iraq, and to a lesser extent in Afghanistan, a more linear-if not traditional-approach of military action with sequential transition to other aspects of national development sees Iraq and Afghanistan still dependent on international aid and assistance more than a decade after the initial military-led interventions and uncertain whether their governance and justice sectors can become effective or their economies can ever be self-sustaining. A bias for military action can mean a bias for incomplete solutions to international issues. Military actionfrom humanitarian support to warfighting-without complementary other-agency actions risks a limited prospect of resolution and can prolong, or worsen, some circumstances.

The final concern with defaulting to military responses without comprehensive guiding strategies is a moral one. Just as the use of force by governments should be a last resort rather than a first impulse, governments have an obligation to put members of the armed forces at risk of injury or death only for justifiable reasons. In his Quarterly Essay, 'Firing line: Australia's road to war', James Brown portrays our national mechanisms for going to war as lacking the necessary institutional rigour. ${ }^{5}$ While he focuses on the way such 'grave' decisions are made-rather than how strategy is managed-his concern is that these decisions should be grounded in public trust and democratic legitimacy. Aside from the 2003 invasion of Iraq, contemporary commitments of military forces have had firm legitimacy within international laws and conventions. However, those same commitments, including combat roles, have generally maintained bipartisan support and have not been the subject of open debate within parliament before deployment.

\section{Getting it right}

The public have, in general terms, accepted that the use of the military has been appropriate and necessary even as Australian casualties mounted in Afghanistan from 2007 to 2012. Although Australia is unlikely to experience a Chilcot-style enquiry regarding Australia's path into Afghanistan, further deterioration in the circumstances in Oruzgan Province might provoke deeper thought about what Australia's strategy

5 James Brown, 'Firing line: Australia’s road to war', Quarterly Essay 62, 2016, pp. 56-8. 
was and what the sacrifices there achieved. It is also likely that there will be a greater call for justification to families of the fallen. Our current process for developing national strategy and for deciding to commit forces to combat do not deliver clear articulation of why physical risks are necessary and just how much we are willing to sacrifice. Attempts to define this before combat commitments would likely demand clearer communication of overarching strategy in support of policies and a clearer statement of what military forces are required to achieve-beyond supporting policy by deployment alone. Military force should always be a political means, not a political end.

The next half-century promises to be one of profound global change. In Australia's own region, we are witnessing the rise of China and India and challenges to a US-led, unipolar order that has maintained relative stability for the last 70 years. While India and China's economies are growing, no Western democratic economies_-including Australia's—indicate similar sustainable growth paths. The most significant expansion in workingage populations will be centred on the African continent in this same timeframe. Access to sophisticated military weaponry and technology is becoming cheaper and easier even for non-state entities. Whether we like it or not, Australia's current relative demographic, economic and military advantages will decline in the decades ahead. Addressing this will require deliberate and careful efforts on a national level. Policy, planning and execution of national strategies will be required to retain or maximise Australia’s advantages.

Strategy, by its nature, is ultimately implemented in a competitive environment and should assume that competitors and adversaries will bring all relevant capabilities into play to achieve desired outcomes. Strategy should also assume that setbacks will occur. Because strategy is competitive, not all its elements can be resolved or discussed in the public domain. While policy objectives might be the subject of open debate, strategies require concealed elements such as which assets are to be employed (means), what tactics will be employed (ways) and what risk tolerances will be acceptable in achieving national goals (aims). Coordination of the elements of national power is difficult during strategy formulation and can be even more so during implementation. A further complication is the requirement to integrate strategies either with allies or coalition strategies and with non-government organisations. Each of these requires specialist practitioners and continued attention, which are not well met by ad hoc mechanisms and relationships. 
As discussed, no area of government is presently tasked to look ahead and to recommend strategy beyond the realm of policy. This needs to change if Australia is to maintain our current influence in an increasingly complex and competitive global order. The successful example of OSB initially necessitated the appointment of a three-star military officer to develop and implement an effective strategy. This has since evolved with the creation of Border Protection Command integrated into the Department of Immigration and Border Protection to manage the full gamut of customs and border security concerns. Early successes notwithstanding, achieving the stated policy objective of ceasing unauthorised maritime arrivals to Australia requires the continued active participation of nearly all other government departments, including the stewardship of the Department of Prime Minister and Cabinet (PM\&C) during implementation of the related strategy. The myriad emerging challenges to each of Australia's elements of national power alone-diplomatic, informational, military and economic - in a world of transnational threats and shifting power balances requires national strategies guiding employment of capabilities beyond those that any one government department can deliver.

In 'Firing line', James Brown argues for the establishment of a body to oversee the commitment of military forces to war. ${ }^{6}$ Although this might be beneficial, the incidence of such commitments is fortunately rare and could be handled in an ad hoc or as required manner. The requirement for national strategies is an enduring one, and it is extraordinary that no entity exists to manage this in Australia. Perhaps more surprisingly, our closest major allies, the United States and United Kingdom, have come to the same conclusion: that they also lack effective mechanisms in this regard. A 2014 RAND report, Improving Strategic Competence: Lessons from 13 Years of War, concluded that the United States suffers from a lack of civilian-military mechanisms for developing national security strategy. ${ }^{7}$ As a result, they have conducted military campaigns without an adequate overarching political strategy. Similarly, a 2010 UK House of Commons report, Who Does UK National Strategy?, identified little evidence of sustained strategic thinking or a civilian-military mechanism

6 Ibid., p. 56.

7 Linda Robinson, Paul D. Miller, John Gordon IV, Jeffrey Decker, Michael Schwille and Raphael S. Cohen, Improving Strategic Competence: Lessons from 13 Years of War, RAND, Santa Monica, 2014. 
for strategic analysis and assessment. ${ }^{8}$ The report went on to cite a lack of development or education of strategic thinkers within academia or government institutions. A similar audit in Australia would identify that we are formally no better off.

To better face this future, Australia would be well advised to develop an Office of National Strategy. It is unlikely that the government would see fit to expand government bureaucracy and establish another entity akin to the Office of National Assessments (ONA), but this would be optimal. Non-government bodies such as think tanks might be commissioned to develop strategy but are not well suited to managing its implementation in a continuous sense. An ONA-like organisation could provide the ability to develop classified strategies for government approval-either on their own initiative or at government direction-and could assist in managing implementation with regular feedback to Cabinet or the NSC. An organisation of similar size to ONA could provide sustainable career paths for a growing body of trained strategists from all agencies. Failing this, the next best alternative would be to establish a team within PM\&C that could convene as required. This group, comprising trained strategists from a range of agencies and disciplines, could provide more consistent oversight of national strategy development and implementation than is presently available to the government. Either of these entities would enhance Australia's current ability to prepare for the future beyond the predominantly short-term focus of governments or the tides of passing popular sentiment. An Australian Office of National Strategy could also ensure that more fulsome decisions are taken about committing Australian military forces and with greater regard to the integration of other elements of national power.

\section{Muddling on}

Australia's circumstances will, in all likelihood, become more complicated and challenging in the next few decades. Australia has many relative advantages both regionally and globally. These will progressively erode without strategies that seek to maximise the advantages inherent in effectively applying the instruments of our national power. Without

8 Public Administration Select Committee, Who Does UK National Strategy? First Report of Session 2010-11, UK House of Commons, Stationery Office, London, 18 October 2010; publications. parliament.uk/pa/cm201011/cmselect/cmpubadm/435/435.pdf (retrieved 29 January 2018). 
a body to develop and implement national strategies, response to crises tends to be reactive rather than planned. This, paired with a bias for action, risks the military —as the most responsive and visible instrument of government - being deployed without clear definition of the intended purpose or being fully integrated with the other elements of national power-and unlikely to deliver an enduring solution. In Australia's case, incremental 'muddling through' has not resulted in circumstances as dire as those criticised in the United Kingdom's Chilcot Report. However, in the enduring absence of a formal mechanism for national strategy, the potential is there if Australia were to become embroiled in an existential crisis.

To re-emphasise, the commitment of military forces should be a component of strategy and not an end itself. Force has its place as an enabler of policybut force alone cannot deliver enduring solutions. Its application should be one means among others to deliver sustainable solutions. Accordingly, national strategies should be just that-strategies—and not strategic policy in the guise of strategy. We need strategy as the bridge from policy to action. Military forces should deliver strategic aims due to necessity, not convenience. To ensure this, we need to foster a greater understanding of the elements of national power and their interrelationships, including the limitations on the utility of military forces. We need to ensure that the strategic dialogue between politicians, bureaucrats, military officers and the public is informed and frank.

Australia has more frequently employed military power appropriately in concert with other agencies in recent years. However, the temptation remains to send the military when rapid action is required. Systemic risk remains that we can race from policy to action without a strategy. While remaining policy driven, we must understand that policy alone is not strategy and that a bias for action is not strategic. Our bias should be for action through national strategies that integrate all the relevant elements of national power. We need to help governments to be strategic. To that end, we need greater investment in bodies to develop strategy, create more strategists and grow a national strategic culture that can best protect Australia's future. This will also help Australia find its sweet-spot as a middle-weight military power in an increasingly challenging region and world. 



\title{
5
}

\section{The prospects for a Great Power 'grand bargain' in East Asia}

\author{
Evelyn Goh
}

The future shape and form of the East Asian regional order presents one of the most pressing concerns for Australian strategic policy planners and analysts, who have also contributed significantly to associated regional and international debates and policy initiatives. ${ }^{1}$ Ultimately, strategic efforts are defined by their ultimate 'big picture' goals. From the broad perspective of cultivating regional order in East Asia, one key goal must be to forge a feasible and sustainable 'grand bargain' among its resident great powers.

For at least the last two-and-a-half decades, East Asia has been plagued by multiple uncertainties, especially regarding the economic and security implications of China's resurgence and the durability of US preponderance and leadership in the region. The latter is currently the greatest of these 'unknown unknowns' following Donald Trump's occupation of the White House in 2017. Moreover, these questions sit alongside other important enduring regional uncertainties, particularly Japan's 'abnormal' military condition, North Korea's nuclear capabilities and the divisions between the two Koreas and between Taiwan and the mainland. In recent years, key voices on both the Chinese and US sides especially have mooted notions

1 A slightly different version of this chapter was first published as Evelyn Goh, "Is a "grand bargain" the way forward in North-East Asia?', Global Asia, Winter 2016, pp. 58-65. 
of closer collaboration and joint great power management in response to these multiple uncertainties - for instance, the idea of Washington and Beijing acting as a 'G2' to tackle global problems, or President Xi Jinping's concept of a 'new model of major power relations' with the United States. But the necessary foundation for any such strategic collaboration must be new fundamental mutual agreements between the United States, China and other major East Asian states. In this vein, a number of scholars and analysts have begun to discuss more seriously the prospects for negotiating 'grand bargains' of one type or another that might help to ease these uncertainties by creating the foundation for a stable new regional order. There are two notable examples.

First, in 2012, Hugh White published a subsequently much-debated book, The China Choice, calling for Washington to share power seriously with Beijing and suggesting that this should take the form of a new concert of powers involving the United States, China, Japan, India and possibly Indonesia. The book pays more attention to making the case for why this radical choice for accommodation is necessary than how it should be put into practice; however, in a small section, White lists seven 'essential understandings' that the two sides must agree upon. In essence, these would be the basis for a new grand bargain between them. The list focuses on mutual legitimacy: treating each other as equals, recognising each other's domestic political systems, respecting each other's national interests and right to develop armed forces sufficient to defend them, committing to resolve differences peacefully, agreeing on the norms of legitimate conduct, mutual willingness to counter attempts to dominate, and ensuring the ability to sell this to domestic audiences. ${ }^{2}$ White does not provide more substantive explanations for what the power-sharing bargain between the United States and China might look like, but the one controversial condition he does mention is that a regional concert would have to include a more 'normal', independently militarised (and nucleararmed) Japan.

The second example is Charles Glaser's 2015 argument that the United States ought to adopt vis-à-vis rising China a 'limited geopolitical accommodation to avoid conflict'. ${ }^{3}$ He specifically proposes that Washington should negotiate a 'grand bargain' that would trade the

2 Hugh White, The China Choice: Why America Should Share Power, Black Inc., Melbourne, 2012, pp. 137-41.

3 Charles L. Glaser, 'A US-China grand bargain? The hard choice between military competition and accommodation', International Security 39, no. 4, 2015, p. 49. 
cessation of the US commitment to defend Taiwan in exchange for China's peaceful settlement on 'fair' terms of its territorial disputes in the East and South China Seas and Beijing's official acceptance of the US military security role in East Asia, including its alliances and forward deployment. $\mathrm{He}$ argues that such a grand bargain would not be neatly symmetrical, but could be acceptable if the two sides can agree to 'trade across multiple issues, making both sides better off, but not necessarily equally'. ${ }^{4}$

Apart from generating much polemical controversy, both of these examples help to advance the debate on US strategy towards contemporary China if only by forcing us to consider more seriously the terms under which a scenario of 'negotiated change' (as opposed to a war-torn power transition) might occur. ${ }^{5}$ In this sense, the debate these works aimed to fuel is about the content of a putative grand bargain between the United States and China.

To contextualise the debate about a possible new grand bargain for the analytical and policy challenges of strategic diplomacy in North-East Asia, I offer three entry points for discussion in what follows. First, I discuss the comparative advantages of adopting a grand bargain framework to understanding how a new regional order may be negotiated. Second, with the reminder that prior strategic bargains already exist in the wider AsiaPacific region, I consider how these pre-existing bargains could interact with the proposals for a new grand bargain. Finally, I briefly review some recent key Chinese ideas about such bargains to highlight the obstacles and opportunities faced by strategic diplomats seeking to broker a new grand bargain in East Asia.

\section{The 'grand bargain' approach}

At its most basic, a grand bargain between two states may be understood in a contractual fashion: it consists of a bundle of agreements by which state $\mathrm{X}$ gives up something of significant strategic value to itself in exchange for state $\mathrm{Y}$ committing to something that is of equal or greater strategic value. The overall purpose would be to bring about more clarity and predictability vis-à-vis their goals and interactions.

4 Ibid., p. 79.

5 For an earlier analysis of negotiated change scenarios compared to power transition, see Evelyn Goh, 'The US-China relationship and Asia-Pacific security: Negotiating change', Asian Security, 1, no. 3, 2005, pp. 216-44. 
A 'grand bargain' is based on the notion that coexistence among states (and especially major powers) is built upon reciprocal commitments, or fundamental political compromises, which allow some form of strategic exchange and interdependence to develop. Between great powers, grand bargains in their most advanced form must entail some form of negotiated constraints to their exercise of power. Grand bargains basically involve implicit or explicit agreement about the mutually acceptable terms on which peaceful relations can be conducted. These include understandings about recognition and status, mutual rights and responsibilities, mutual spheres of influence, terms of exchange and conditions of restraint. It is on this basis that scholars sometimes argue that the United States and China, or China and Japan, will need to negotiate a grand bargain between themselves and even with other key states in East Asia for regional security and stability to prevail. ${ }^{6}$

In general, the big advantage of a 'bargain' approach to understanding and influencing great power relations is its innate relationality: the reciprocal and transactional assumptions underpinning bargains obliges us to examine and try to reconcile the preferences, goals and tactics of each of the parties involved. This sits in contrast to the one-sided notions of containment or appeasement that often seem to dominate debates about how to respond to China's rise, for example. Thinking about bargains involves taking seriously what the other side wants and values. Moreover, a grand bargain approach helps us to grasp the complexity of international orders. On the one hand, it connotes linkage across issue areas (as Glaser suggests). But it also crucially entails a systemic perspective beyond bilateral relationships; for instance, a grand bargain lens should additionally allow us to probe the broader regional and historical contexts that clearly affect the attractiveness, viability and scope of any putative new US-China bargain.

6 See Evelyn Goh, 'Japan, China, and the Great Power bargain in East Asia', East Asia Institute Fellows Working Paper Series no. 32, November 2011, www.eai.or.kr/data/bbs/eng report/2011103118375220.pdf (retrieved 29 January 2018). The key related approaches on institutional bargains, peace settlements and social compacts are respectively G. John Ikenberry, After Victory: Institutions, Strategic Restraint, and the Rebuilding of International Order after Major Wars, Princeton University Press, Princeton, 2001; Ian Clark, The Post-Cold War Order: The Spoils of Peace, Oxford University Press, Oxford, 2001; and Evelyn Goh, The Struggle for Order: Hegemony, Hierarchy and Transition in Post-Cold War East Asia, Oxford University Press, Oxford, 2013. 
From such a starting point, we may identify at least two issues critical to the possibility of a grand bargain in contemporary East Asia: the effects of existing strategic bargains, and Chinese notions of the acceptable terms for a bargain with the United States. Both these issues affect how desirable proposals for grand bargains like White's and Glaser's might be from the points of view of China and crucial US allies in the region.

\section{Strategic bargains in the status quo ante}

Strategic bargains form the sinews of international order, and while they are most likely to be struck at critical junctures such as following crises or wars, once struck they do not simply disappear but continue to evolve and might be renegotiated. As such, anything we may propose in the contemporary setting would in fact be a new grand bargain between the United States and China. It would not be created from scratch, because the status quo ante is already marked by a series of 'grand', regional, trilateral and bilateral bargains. This is a fundamentally important point-it shows that Washington and Beijing (and other East Asian states, for that matter) have been and are capable of striking bargains. But this understanding also presents constraints for any new proposed bargain because it will involve revising or renegotiating previous, disintegrating or continuing bargains between the United States and China, and between them and Taiwan as well as Japan.

The most important systemic context for a new bargain is the post-Cold War economic security grand bargain between China and the United States. The economic side of this bargain is crucial but undergoing a difficult transformation. In simple terms, the bargain is based on intensified interdependence underpinned by the US dollar as the world's reserve currency. Like other supporter states, China has gained access to the US market in exchange for its undervalued currency, which in turn supports massive US state spending. Essentially, this is a bargain that China and other key lenders and exporters keep accumulating US dollars while the United States keeps consuming foreign goods and services. ${ }^{7}$ As Michael Mastanduno argues, this grand systemic bargain has been fatally undermined by the global financial crisis, which will force

7 Michael Mastanduno, 'System maker and privilege taker: US power and the international political economy', World Politics, 60, no. 1, 2009, pp. 121-54; Steve Chan, Looking for Balance: China, the United States and Power Balancing in East Asia, Stanford University Press, Stanford, 2012. 
the United States to eventually draw down domestic consumption and borrowing, and consequently also reduce its tolerance for China's exportled growth strategy. In parallel, since the crisis, China has redoubled its focus on developing its domestic consumer market, and tried to diversify its foreign reserves holdings away from overdependence on US dollars. Both these trends are reducing their mutual interdependence, and, as their 'special economic relationship' becomes less special, so too will their mutual strategic restraint be dampened and their security relationship further strained. ${ }^{8}$ Given this trend, China's incentives to strike a new asymmetrical bargain with the United States, like the one Glaser suggests, are unclear.

On the security side, any new US-China grand bargain would have to grapple with another central but disintegrating previous bargain. During the Cold War, the East Asian order was underpinned by the alliance between the United States and Japan in which Washington extended its security umbrella over Tokyo in exchange for Japan's disarmament, pacification and guaranteed alignment with the 'free world'. In effect, this bargain saw the United States stepping into the breach between Japan and China as an 'outside arbiter play[ing] a policing role'. By making Japanese defence dependent on itself, the United States extended a 'dual reassurance', simultaneously guaranteeing China and Japan their security against each other, obviating the need for them to engage in direct security competition. ${ }^{9}$ After 1995, the revitalisation of the US-Japan alliance based on Japan playing a more active regional and global military role seemed to undermine Washington's ring-holding ability between Japan and China. Beijing began to regard the US-Japan alliance less as a means to constrain than to facilitate Japan's remilitarisation, a view reinforced by the central role of the alliance in the more recent US 'rebalance' to Asia. ${ }^{10}$ There is also a growing view within China that the United States used the cover of the alliance to 'illicitly transfer' sovereignty over the Senkaku/ Diaoyu Islands to Japan during the 1970s. ${ }^{11}$

8 Michael Mastanduno, 'Order and change in world politics: The financial crisis and the breakdown of the US-China grand bargain', in Power, Order and Change in World Politics, ed. G. John Ikenberry, Cambridge University Press, Cambridge, 2014, pp. 162-91.

9 Thomas J. Christensen, 'China, the US-Japan alliance and the security dilemma in East Asia', International Security, 23, no. 4, 1999, p. 50; Hugh White, 'Why war in Asia remains thinkable', Survival 50, no. 6, 2008-09, pp. 85-104.

10 For a fuller explanation of this shift, and how Sino-Japanese normative tensions feature within it, see Goh, Struggle for Order, Chapter 5.

11 Amy King, 'Where does Japan fit in China's "new type of great power relations"?', Asan Forum, 24 March 2014. 
Using the lens of these disintegrating existing strategic bargains highlights the major unresolved sticking point of Japan's increasingly contested role in the regional order. While Glaser does take Japan into account, his main concern is whether ending the US defence commitment to Taiwan will negatively affect the credibility of the US alliance with Japan. ${ }^{12}$ But the US-Japan alliance has already changed in character-and from China's point of view to the detriment of a previous bargain. Thus, any proposed new Sino-American bargain that takes the US-Japan alliance as a constant while asking both China and Japan to make concessions in their territorial disputes is unlikely to be acceptable. Many Chinese no doubt would prefer to continue to characterise Japan as a second-rate 'American lackey', but increasingly under President Xi Jinping's 'striving for achievement' strategy, these two allies are being differentiated, with the United States viewed as China's only strategic competitor and Japan as one of its key 'hostile countries' ${ }^{13}$ Against this background, the assumption that Japan's 'normalisation' is an inevitable prerequisite for regional power-sharing is too casual. Arguably, there is now more than an unintentional security dilemma between China and Japan, ${ }^{14}$ and their growing conflicts of interest and nationalism are likely to create an insecurity spiral that will undermine the prospects for a US-China grand bargain that involves any compromise between China and Japan.

Pre-existing and evolving bargains also surround the issue of Taiwan that is central to Glaser's proposed strategy of territorial accommodation. On Taiwan, China and the United States achieved a limited bargain during the 1979 normalisation based on the principle of 'one China'. Beijing was accorded diplomatic recognition and authority over all China, and Washington recognised that Taiwan is part of China and relinquished the right to encourage Taiwanese independence (although not its right to sell arms to Taiwan). While they agreed on the peaceful means of resolving the problem, they disagreed on the necessity of reunification as the eventual outcome. ${ }^{15}$ Since then, China and the United States have each tried to negotiate alternative bargains with Taiwan, partly to stabilise

12 Glaser, 'A US-China grand bargain?', p. 77.

13 Yan Xuetong, 'From keeping a low profile to striving for achievement', Chinese Journal of International Politics 7, no. 2, 2014, p. 170.

14 Adam P. Liff and G. John Ikenberry, 'Racing toward tragedy? China's rise, military competition in the Asia Pacific, and the security dilemma', International Security 39, no. 2, 2014, pp. 52-91.

15 See Richard C. Bush, At Cross Purposes: US-Taiwan Relations since 1942, M.E. Sharpe, Armonk, 2004; Nancy Bernkopf Tucker, Strait Talk: United States-Taiwan Relations and the Crisis with China, Harvard University Press, Cambridge, MA, 2009. 
the remaining ambiguities of the status quo ante. The rival models come across clearly in an illuminating exchange between a Chinese and an American scholar, Jia Qingguo and Alan Romberg. ${ }^{16}$ Beijing's offer is in the form of the 'one country, two systems' track of reunification, whereby Taiwan would trade independence for the preservation of its separate political system (exactly how is unspecified) and even control of its own armed forces. ${ }^{17}$ The current US bargain with Taiwan aims at preserving the status quo, exchanging the US defence commitment and arms sales for Taiwan's 'three nos' to war, unification or independence. Ceasing US defence for Taiwan as Glaser suggests will mean not only withdrawing the US bargain but also making the Chinese one unnecessary, thus changing the potential terms of reunification. Understanding this context is important because it suggests that while Taiwan is central to China's security and national identity, Beijing might not place as high a value on potential US accommodation on this issue as Glaser suggests. Within the Chinese discourse, there is grave doubt anyway about whether the 'Taiwan card' is really that powerful any more in the relationship with the United States, given that China thinks that time is on its side. ${ }^{18}$ Thus, while accommodation on Taiwan is essential, it is unlikely to be sufficient to make Glaser's grand bargain acceptable to the Chinese. ${ }^{19}$

16 Qingguo Jia and Alan D. Romberg, 'Taiwan and Tibet', in Debating China: The US-China Relationship in Ten Conversations, ed. Nina Hachigian, Oxford University Press, New York, 2014, pp. 176-97.

17 Ibid., p. 181. On this 'paradigm of persuasion' adopted by the Ma Administration after 2008, see Richard C. Bush, Unchartered Strait: The Future of China-Taiwan Relations, Brookings Institution Press, Washington, DC, 2013.

18 Pan Fei, 'Zhongmei zai yatai diqu de zhanlüe hudong yu Obama zhengfu de duitai zhengce' [Sino-American strategic interaction in the Asia Pacific and the Obama Administration's Taiwan policy], Taihai Yanjiu [Taiwan Straits Studies], February 2015, pp. 76-84; Robert Sutter, Taiwan's Future: Narrowing Straits, National Bureau of Asian Research Analysis, May 2011.

19 There is of course a deeper problem here in the tendency to objectify actors and political entities in the region to the extent that would support assumptions that issues, territories and peoples may be horse-traded in a fungible manner. This problem is echoed in other suggestions-for example, that the United States might cut a bargain with China by 'foreswearing any intervention in a SinoJapanese conflict over the [Senkaku] islands in return for Chinese commitments to work on a legally binding code of conduct for the South China Sea dispute, or increased efforts to get North Korea to reduce or even eradicate its nuclear arsenal' (William Choong, 'The ties that divide: History, honour and territory in Sino-Japanese relations', Adelphi 445, International Institute for Strategic Studies, London, 2014). 


\section{Regional and Chinese ideas about strategic bargains}

Within China, a debate is growing slowly but steadily in the transition away from Deng Xiaoping's taoguang yanghui policy of biding time to develop comprehensive national power towards questions of what kind of great power China should be and whether China ought to support or challenge the existing order. But this is still a gradual awakening, and, without more coherence in narrowing down the parameters of this struggle for identity, power-sharing with the United States cannot be an option seriously favoured by opinion leaders against the backdrop of growing popular nationalism within China. Other countries in East Asia, meanwhile, either sustain national security identities that feed upon the assurance of continued US primacy, ground their national security strategies upon at least some degree of US-China rivalry, or seek to retain some strategic autonomy by forestalling great power domination. For all three reasons, any new bargain premised upon a potential US-China condominium is distasteful. Looking beyond North-East Asia, in SouthEast Asia, it is hard to imagine effusive support for the concert of great powers White suggests, which would by definition exclude the majority of these small states. This was already evident in the Association of Southeast Asian Nation's (ASEAN) successful attempts to undermine an earlier Australian initiative to construct a major power-centred Asia-Pacific Community. Once again, picking out Indonesia as a subregional power only elicits alarm and resistance from this collection of states, which have expended so much political and institutional effort to create for ASEAN a 'driving seat' in regionalism precisely to avoid great power dominance that would undermine their autonomy.

Returning to North-East Asia, the ideational, domestic political and strategic complexities that many scholars so vividly underscore on the US side are replicated on China's part. First (and perhaps helpfully for anyone inclined to propose new bargains), the idea of strategic bargains comes naturally to many Chinese foreign policy interlocutors and their counterparts. For example, both China and Japan see the recent intensification of their territorial dispute in the East China Sea as resulting from the other side reneging on their 1972 normalisation agreement to set aside the dispute: the Chinese perceive Tokyo to have reneged on it in 2012 when the Noda Government bought the Senkaku Islands, while the Japanese see Beijing as having reneged earlier in the 2000s by significantly 
increasing paramilitary and military operations in the area and allowing more aggressive forms of confrontation on the ground. In the South China Sea too, the Chinese see then Secretary of State Hillary Clinton's 2010 diplomatic intervention in publicly criticising Chinese assertiveness as reneging on US professions of neutrality, while many Americans viewed reports of Chinese pronouncements about the area as a 'core interest' as evidence of an expanding Chinese sphere of claimed influence reneging on professions of 'peaceful rise'.

Second, there is a Chinese discourse considering what a strategic bargain with the United States might look like, particularly since talk of a 'G2' and since President Xi Jinping introduced his notion of 'a new model of major power relations'. In a fairly typical liberal vein, Wu Xinbo argues that 'it is time for China and the United States to try to reach an understanding on the evolving regional architecture through candid dialogue', one encompassing 'more equal relations between the two sides of the Pacific'. ${ }^{20}$ The theme of a more equal exchange is echoed in a recent Shanghai Academy of Social Sciences project on US-China relations, which states that China would support a 'positive leadership role' for the United States if the latter would also support a 'more positive and vigorous role in East Asia' that 'leaves more room for maneuver for China in terms of claiming territorial rights and military development'. Specifically, the United States needs to 'recognise China's sovereignty claims within its historical rights', 'avoid getting involved in the territorial disputes between China and its neighbors', and 'should never interfere militarily in the disputes and crises between China and its neighbors. ${ }^{21}$

At least one Chinese scholar, Shi Yinhong, has explicitly discussed what a more equal bargain between China and the United States would look like at a broader grand strategic level. His proposition is for a 'peaceful "final settlement" based on 'selective preponderance' in complementary realms. ${ }^{22}$ The United States would accept China's leading position in Asia based on its superior economic size, trade volume and regional

20 Wu Xinbo and Michael Green, 'Regional security roles and challenges' in Hachigian, Debating China, p. 202.

21 Institute of International Relations, Shanghai Academy of Social Sciences, 'Zhongmei xinxing daguo guanxi jianshe: Zhanlüe renshi yu lujing xuanze' [New type of great power relations between the US and China: Understanding strategy and future choices], Guoji Guanxi Yanjiu [Journal of International Relations], no. 6, 2014, pp. 18-19.

22 Yinhong Shi, 'The United States, East Asia and Chinese "triumphalism"', in China's Rise and Regional Integration in East Asia, ed. Yong Wook Lee and Key-young San, Routledge, Abingdon, 2014, p. 48. 
influence; mutual deterrence based on China having military parity and even marginal superiority in China's offshore areas (with Taiwan's eastern shore being the 'prudent' line); peaceful reunification of Taiwan with the mainland; and China 'maintaining strategic space in a substantial but still narrow span of the western Pacific'. In return, China would accept US overall military superiority globally and in the central and western Pacific, and preponderant US influence in other world regions.

\section{Conclusion}

Strategic thinking needs to start from a consideration of the desired ends of policy. In terms of order in East Asia, one indispensable goal must be some modus vivendi among the major powers. As this brief overview suggests, there are some significant hurdles to be negotiated if we look slightly further down the line in considering how attractive current USoriented propositions of a new grand bargain might be to the Chinese audience. At the same time, these proposals would have to contend with the continuing attempts at renegotiating and contesting a number of bargains underpinning key bilateral relationships and regional order in East Asia. Any form of negotiated change in the US-China bilateral relationship will necessitate significant reversals to both US and Chinese mindsets and ambitions. The same huge challenge faces attempts to consider deep-seated change in the China-Japan relationship.

The bottom line is that a grand bargain is possible in East Asia-but it will entail sea changes in attitudes and expectations on every side. History suggests that groups of states find it very difficult to undertake transformational changes like this without the radical impetus (or shock) of systemic war. But such exercises in strategic thinking can help, at least by creating opportunities to stimulate what often seems to be the unthinkable vis-à-vis each other in Washington and Beijing, and between Beijing and Tokyo: non-military cooperative modes of security behaviour and non-zero-sum strategic interactions with each other. Generating a plethora of ideas and encouraging constructive debate about these issues is essential because, ultimately, a stable regional order will depend upon these major powers' ability to reach basic strategic modus vivendi with each other. 



\title{
6
}

\section{Old wine in new bottles? The continued relevance of Cold War strategic concepts}

\author{
Robert Ayson
}

Cold War strategic concepts played a significant part in my time as a student at The Australian National University (ANU). Arriving in Canberra in the early part of 1988, the penultimate year of the multidecade struggle between East and West, I joined the smaller predecessor to today's much larger master's program. The core course in that original master's degree was dominated by a subject that has largely disappeared from today's teaching in strategic studies. This was the strategic nuclear balance between the United States and the Soviet Union and, in our case, there was a particular focus on the development of US nuclear strategy.

I owe a great deal to those half dozen nuclear strategy lectures and to the wonderful academic who delivered them: Professor Desmond Ball. In his classes, Professor Ball examined in detail the stability of that superpower nuclear balance. And it was the concept of stability in the Cold War period, and specifically Tom Schelling's work on that idea, that formed the topic of my PhD thesis at King's. Had it not been for the encouragement from Strategic \& Defence Studies Centre (SDSC) academics who had taught me here in Canberra, I expect I would have had little chance of working in London with Lawrence Freedman, whose enthusiasm for the history of strategic ideas continues to be a major inspiration to me. 
With that background, you might expect me to choose stability as my chosen strategic concept from the Cold War. That possibility did cross my mind. But instead I will look at something stemming from another topic we covered in that 1988 core course. In this case, however, there was but one lecture. The theme was crisis management, and our teacher that day was Coral Bell.

Crisis management among the great powers, often against the risk of nuclear annihilation if these crises were mismanaged, runs through a good deal of Bell's work. In reading her slim volume, The Conventions of Crisis, while I was on sabbatical here in 2013, one concept stood out to me as an approach to understanding the management of Great Power crises. This was an idea that Bell said she had borrowed from the Soviet specialist Marshall Shulman. ${ }^{1}$ It was to view the relationship between the main Cold War protagonists, the US and the Soviet Union, as an adverse partnership. And that concept is my focus in this chapter.

So what does, or perhaps what did, an adverse partnership consist of, and why was it important? As for the first question, an adverse partnership is pretty much what its two component words in combination suggest it to be. It is to regard adversaries, even when they are very serious rivals, as possible partners. It is to suggest that two or more great powers, whose relationship is characterised by deep competition, can nonetheless also find ways to work together, presumably on the basis that they have common interests as well as conflicting ones. A primary focus for their limited cooperation is the conscious management of the conflict that exists between them, avoiding its escalation into a situation that both of them will regret.

At the same time, we should not get too carried away, and Bell was generally not one to do so. An adverse partnership also implies that even when we do see great powers working together, we should not be fooled into thinking that they are no longer adversaries. These partners remain adversaries. Their limited cooperation is much more about coexistence than friendship. There is nothing harmonious here.

1 See Coral Bell, The Conventions of Crisis: A Study in Diplomatic Management, Oxford University Press for Royal Institute for International Affairs, London, 1971, p. 50n. 
By 'adverse partnership' [she explained], I do not mean to imply anything particularly cordial, trusting or friendly: only a consciousness, between the dominant powers, that they have solid common interests as well as sharp conflicting interests. ${ }^{2}$

The main point is that cooperation can coexist with competition. Neither one of these facts of international life needs to rule out the other.

And why is the idea of an adverse partnership important? Let me give two answers to that question. One applies to our own fading memories of the Cold War period, memories that we now seldom have in common with the majority of our students, who were born some years after the Berlin Wall was torn down. When I ask my undergraduate students for their first political memory, for some of them it is $9 / 11$. But some of them do not even remember that far back.

For their benefit, it concerns me when the Cold War is stereotyped because of academic laziness or because of the simplification of complex history to serve geopolitical agendas. Academically, I do not take much relief from any view, however widely accepted it may be, that the United States and China are not sliding into a US-Soviet-style Cold War. To establish that position is no reason to take our eyes away from the still hazardous strategic competition between Beijing and Washington. Geopolitically, we should be wary of arguments that drawing Cold War parallels is a no-go zone. For the United States, acknowledging the possibility of a Cold War with China may also be to endorse containment as a central Cold War strategy. For China, the lesson from Russia's experience is that a cold war can end with the dissolution of the contained power. Moreover, for great powers like China and Russia that remain outside the US alliance system, there is the convenient argument that these alliances reflect an obsolete Cold War mentality. Most of these positions say much more about political preferences than they do about accurate perceptions of the situation.

Amid these politically charged battles for the interpretation of the postwar order, it is not surprising if some of our students see the Cold War as a period of unrelenting zero-sum competition. But the idea that the principal adversaries of that era can be regarded as partners as well as competitors suggests that this view is false. This is one reason why thinking about adverse partnerships is important. To regard Soviet Russia and the United States as adverse partners is one way of reminding ourselves, and

2 Ibid., p. 50. 
our students, that Cold War tensions and anxieties waxed and waned. It helps us remember that, although these tensions were very serious and dangerous, they did not lead inevitably to war.

Above all, this picture of Great Power relations reminds us that in some situations rivals can actually manage their conflict. For those of us who like to emphasise the role of agency in strategy, and to suggest that strategic actors have choices that can affect the choices of others, the notion of an adverse partnership becomes even more significant.

Second, the conception of a US-Soviet adverse partnership is important for its place in debates that went on during the Cold War. We forget how revolutionary it was to argue that the two supposedly implacable foes could also be seen as partners. The United States and Soviet Union were after all geopolitical, ideological, economic, cultural, military, diplomatic and sporting rivals. The notion that they could also be partners rested uneasily alongside that fact.

This argument was perhaps not quite so hard for Coral Bell to make; after all, The Conventions of Crisis was published in 1971, by which time the short-lived superpower détente had well and truly taken hold. This was a year before the Strategic Arms Limitation Treaty I (SALT I) talks, including the Anti-Ballistic Missile (ABM) Treaty, would be completed successfully, a formal sign of the ability of the two superpowers to set limits on their nuclear competition. Washington and Moscow might have defined strategic stability in less than identical ways, but their arms control agreements reflected their joint assessment that they had a common interest in regulating a major aspect of their Cold War competition. ${ }^{3}$ Both saw mutual survival as a core interest, to use a term that has become associated with the foreign policy of today's China. But unlike Beijing's assertions today, it was a core interest the two sides had in common.

Today we are probably even more comfortable with the argument that the major nuclear powers needed to see themselves as partners in avoiding mutual annihilation. But in the late 1950s, when a fairly young American economist was asserting that the nuclear-armed superpowers had common interests (as well as competitive ones), he was actually explaining a point of departure for post-war strategic studies. This economist was Thomas Schelling, who argued that it was best to characterise the US-Soviet

3 I take this argument from Hedley Bull, The Control of the Arms Race: Disarmament and Arms Control in the Nuclear Age, Weidenfeld \& Nicolson, London, 1961, p. 10. See my analysis in Robert Ayson, Hedley Bull and the Accommodation of Power, Palgrave Macmillan, London, 2012. 
bilateral strategic interaction as a non-zero-sum bargaining relationship. They were not the pure competitors that orthodox microeconomics suggested would lead naturally to a market equilibrium. Instead, they were more like the two big oligopolistic firms whose every move depended on the move the other made, and whose self-interests did not include the disappearance of each other. ${ }^{4}$

The superpowers were like members of a cartel who needed to regulate their conflict out of mutual interest, where the market mechanism could not be relied on. They were, in other words, adverse partners (a term I do not think Schelling himself quite came to use). Lawrence Freedman identifies this logic perfectly when he argues, in his epic Evolution of Nuclear Strategy, that '[a]t the centre of the strategy of stable conflict was the concept of incomplete antagonism'. ${ }^{5}$ The follow-on from that statement is that the incomplete antagonism provided an opportunity for managing the conflict.

Strategy to Schelling was a question of manipulating risk, but this logic worked only if you thought the other side had an interest in keeping the competition within limits. Threats of harm were more important than actual violence, and they were also more meaningful because actual violence could be so utterly devastating in the nuclear age. ${ }^{6}$ Once the Russians had broken the United States' nuclear monopoly, a full-scale nuclear exchange would resemble the category of absolute war, which Clausewitz, writing more than a century beforehand, had suggested was philosophically necessary but which in normal circumstances was practically unreachable. Bernard Brodie's famous warning in 1946 that from now on armed forces must be used to prevent war rather than prosecute $i^{7}$ had indicated that nuclear weapons, if not managed properly, could make Clausewitz's philosophical category all too real. This was just how it seemed to Hedley Bull, a close follower of Schelling's work, who suggested that the nuclear age had also rendered obsolete Clausewitz's observation that war did not consist of a single instantaneous blow. ${ }^{8}$

4 See Thomas C. Schelling, The Strategy of Conflict, Harvard University Press, Cambridge, MA, 1960.

5 Lawrence Freedman, The Evolution of Nuclear Strategy, 2nd edn, Macmillan/St Martin's Press with International Institute for Strategic Studies, Basingstoke and New York, 1989, p. 208.

6 He developed this theme in Thomas C. Schelling, Arms and Influence, Yale University Press, New Haven, 1966.

7 Bernard Brodie, The Absolute Weapon, Harcourt Brace, New York, 1946, p. 74.

8 See Hedley Bull, 'Society and anarchy in international relations', in Diplomatic Investigations, ed. Herbert Butterfield and Martin Wight, Allen \& Unwin, London, 1966, p. 46. 
We know that Bull also favoured the logic of adverse partnerships even though he also probably did not use the term. This precocious scholar, who took up his ANU chair a year after the SDSC was established, argued that the great powers had a special responsibility to recognise and nourish their common interests in the working of an international society. Principle among those common interests was the avoidance of major war, which the presence of nuclear weapons would make especially catastrophic. Bull saw that a fairly crude equilibrium of power in the form of the balance of terror had been created by the superpower arms race. But he argued that there was nothing permanent about this situation, which he therefore referred to as an accident of history. Instead, the Americans and the Russians were obliged to take deliberate steps to manage their conflict if deterrence was to be stable. They needed to recognise, in other words, that they had to be partners in order to manage the most dangerous aspects of their adverse tendencies.

It would be wrong to suggest that this theme was recognised consistently by all who adopted it, or that each one of the scholars mentioned here saw the adverse partnership operating in the same fashion. In 1980, as the Cold War was reintensifying, Bull, now back in Oxford, launched a stinging attack on Moscow and Washington for ignoring their Great Power responsibilities to international society, including their retreat from arms control. ${ }^{9}$ But barely half a decade later, and a year after Bull's untimely death in 1985, John Lewis Gaddis described in his essay, 'The long peace', the rules of the game that both the United States and the Soviet Union had adhered to in order to maintain a measure of stability in their otherwise hazardous relationship. ${ }^{10}$ Bull might well have agreed with Gaddis here as he had a strong tendency to disagree with himself. But years earlier, when the superpowers were in the middle of relaxing their tensions, even Shulman was not sure they had got it right. In 1971 he argued:

security in the realm of strategic weapons would be best served by a stable equilibrium at as moderate a level as can be managed through explicit or tacit agreement with our adversaries. On this point, the interests of the two countries are not opposed, but on neither side is this fact yet fully appreciated. ${ }^{11}$

9 See Hedley Bull, 'The great irresponsibles? The United States, the Soviet Union and world order', International Journal 35, no. 3, 1980, pp. 437-47.

10 John Lewis Gaddis, 'The long peace: Elements of stability in the post-war international system', International Security 10, no. 4, 1986, pp. 99-142.

11 Marshall Shulman, 'What does security mean today?', Foreign Affairs 49, no. 4, 1971, p. 617. 
All of these perspectives could be right, of course. If partners are also adversaries, we cannot expect their partnership to be smooth or thoroughly consistent. Theirs is a rocky marriage in which they cannot live with each other but cannot live without each other as well. This helps us paint a more realistic view of Cold War strategic relations than the cardboard cut-out varieties we see in so much of the modern discourse. Just as some see the Cold War as an especially difficult and competitive period of international politics, which today's Asia cannot afford to repeat, some others are tempted to look back nostalgically on an era that was not nearly as simple or stable as they might think. It is easy to forget that some of the crises that were survived in the Cold War could have become very serious.

This makes it even more important to lay out the factors that made for an adverse partnership. I think there were five of these in the Cold War adverse partnership.

The first of these might seem striking for us today. For the most part, when we think about US-Soviet Cold War strategic relations, the first thing that does not come to mind is their economic relationship. Containment was possible, we might think, because they were members of separate economic systems: one open and liberal, the other closed and centralised. But things were more complex than this initial picture suggests. There was at least some economic exchange, including in wheat sales. In a 1973 essay, Shulman argues that a 'cooperative side of the economic relationship' was 'reflected in the massive Soviet effort to expand its imports of grain, technology and consumer goods, and to develop Western markets for Soviet goods to pay for these imports in the future'. ${ }^{12}$ But it would be an entirely different step for us to assert that the Russians and Americans could always fall back on their common economic interests when the going got tough. This is worth remembering if we think that all the great powers have to do in the 21 st century to run an adverse partnership is to attend to their relationships of economic interdependence.

The Cold War adverse partnership was based much more on restraint in the political-military arena, in the issues we in strategic studies tend to focus on.

12 Marshall Shulman, 'Toward a Western philosophy of coexistence', Foreign Affairs 52, no. 1, 1973, p. 38. 
But the nature of this restraint brings to mind a second important factor. To use Schelling's terminology, to which I am somewhat addicted, the adverse partnership was as much tacit and informal as it was explicit and formal. At times it was so tacit that the very existence of a partnership was plausibly deniable.

We should not overlook the importance of formal agreements such as the ABM Treaty, and other obvious collaboration including Incidents at Sea Arrangements. But, as Bull argued, these agreements were but symbols of the deeper recognition of common interests that constituted the limited understanding between East and West. A great deal still depended on the unilateral nature of that restraint. Tacit signalling, as opposed to formal negotiation, mattered a great deal. Bell asserts in The Conventions of Crisis that 'the basic instrument of crisis management is what I shall call the signal':

By signal I mean a threat or offer communicated to the other party or parties to the crisis. Such signals [she added] are not necessarily verbal messages. Some of the sharpest and most effective of them are movements of military resources of various sorts. ${ }^{13}$

But therein lies a potential problem. One wonders whether the adverse partnership was akin to what Hedley Bull once said about Schelling's tacit bargains. As he said in reviewing Schelling's Arms and Influence:

I find it hard to recognize American and Soviet behaviour in his picture of two governments orchestrating by purposive individuals, sending and receiving messages and ironing out understandings in these ... fields with scarcely as much as a nod or a wink. ${ }^{14}$

A third factor is that these threats of force and other signals were used to sustain the central agreement on which the partnership relied. This was the informal agreement to avoid actual major hostilities. There might also have been something of a tacit understanding to deflect the competition into other areas, including the fighting of proxy wars, the competition for allies and the arms race itself. ('In modern conditions', Bell tells us, 'it is only wars of limited objective and limited liability that have been found

13 Bell, The Conventions of Crisis, p. 73. A number of these themes had been explored by Schelling, including in T.C. Schelling, 'Signals and feedback in the arms dialogue', Bulletin of the Atomic Scientists 21 , no. 1,1965 , pp. 5-10.

14 Hedley Bull, 'Review of Arms and Influence by Thomas C. Schelling', Bulletin of the Atomic Scientists 23, no. 3, 1967, pp. 25-6. 
feasible. ${ }^{15}$ But even limited wars between the superpowers were out of bounds.) The crucial point is that so much of the conflict management that did occur did not happen through carefully calibrated exchanges of actual violence-it was conflict management through coercion and the management of that coercive diplomacy itself. If we regard mutual deterrence in the way Schelling refers to it as the exchange of all possible hostages, ${ }^{16}$ we can see how coercion (in the form of the threats of major harm) was used to sustain a joint no-attack commitment.

And a fourth stems from that: the incredibly high stakes of the game that was being played. I do not think even the most worrying climate change picture we can imagine today can quite compete with the potentially instantaneous gravity of a full-on thermonuclear exchange. The difference of course is that we are already getting at least some climate change. There is a good chance the world will never experience thermonuclear war; however, it was when both sides during the Cuban Crisis stared at the brink of that apocalypse that the arguments of Thomas Schelling, Hedley Bull and others really gained wings. It meant that the fostering of an adverse partnership was not desirable. It had become essential.

A fifth factor also has to be mentioned: how dependent others were on the adverse partnership that the two great nuclear powers were willing and able to strike. This feature only reinforced their dominance of the international system. The adverse partnership was an agreement between the elite powers, and it meant a willingness to subordinate the interests of even close allies if these got in the way. The two main powers remained in a more or less oligopolistic position, although in Asia, with China's emergence, more of a triangle emerged.

An obvious and necessary question to ask is whether this formulation does have continued relevance. Given my argument that we often exaggerate the competitiveness of Cold War relations in comparison to our perception of today's Great Power picture, and my corresponding view that there is more continuity than we are often led to believe between the Cold War and post-Cold War worlds, you might think my answer to this is a resoundingly positive one.

15 Bell, The Conventions of Crisis, p. 49.

16 Schelling, The Strategy of Conflict, p. 231. 
My answer is yes, but only to a point. Let me explain what I mean courtesy of the most obvious early 21 st-century test case for an adverse partnership, nothing other than today's Great Power interaction between the United States and China. How that relationship evolves, and what it means for Asia's security, and what that then means for Australia, will be the most important set of connected questions for many of the next 50 years of the SDSC. So this is no idle consideration.

In the second decade of this new century, we are not as surprised as some Cold War audiences might have been about the possibility of adverse partnerships. ${ }^{17}$ After all, we are all aware of the close economic relations that the United States and China enjoy, which give them a common economic interest the Russians and Americans largely lacked. Hence, the first consideration regarding the adverse partnership seems in much better nick today than in the era of East-West strategic interaction.

Yet I wonder whether there is a problem here. The economic interconnectedness between China and the United States is at least partly an accident of economic history. It is as much a consequence of a decision made by Deng Xiaoping and his successors for China to engage the global economy and of the activities of self-interested US commercial enterprises as it is a deliberately choreographed situation that has been cooked up between Beijing and Washington. This interdependence is not the guarantee of a commitment to conflict management that some might want to think.

In terms of the second factor, we had better hope that the conflict management that does occur directly between China and the United States lies through informal, tacit and unilateral actions. I say that because there is not a great deal of evidence for formal security collaboration.

This is not the end of the world. The two sides can work together without counting rules, without incidents at sea agreements and even without China's involvement in whatever will become of Strategic Arms Reduction Treaty (START). They do not necessarily require an Asian version of the Conventional Armed Forces Treaty. Nor do they need the East Asia Summit to do the impossible and create some real institutional legs. They can also agree to work together in formal responses to the security

17 For one significant depiction of their other than zero-sum relationship, see Rosemary Foot, 'China and the United States: Between cold and warm peace', Survival 51, no. 6, 2009-10, pp. 123-46. 
challenges that third parties pose to international and regional securitythink of joint US and Chinese involvement in the Iran nuclear deal, or their ability occasionally to vote for the same resolution on North Korea at the Security Council.

But in terms of their management of their own bilateral security relationship, the formal symbols of a deeper understanding are few and far between. This does not mean that they cannot have such an understanding. The two sides meet regularly at the US-China Economic and Strategic Dialogue. Washington and Beijing recognise that they have a common interest, for example, in not allowing their South China Sea grandstanding to escalate to war. They have a common interest in making sure that Taiwan continues to avoid moving formally to independence. They recognise a common interest in avoiding war in the East China Sea, and in ensuring through compatible unilateral signalling that Tokyo does not push either of them too far in that direction.

If there is such a common underlying commitment to keeping their own conflict within limits, that is well and good. But I am not sure how persuaded we should be of this. Does the relative absence of formal signs, including in arms control, suggest that the underlying informal understanding has not really been struck, or needs renegotiating? I wonder how much of an adverse partnership is really there.

At least initially, the third factor seems to be met without any question. This is a mutual commitment to use coercion rather than war itself as a way of managing the conflict, and indeed as a way of avoiding severe escalation to war. There has been no major power war in Asia for decades, and the commitment of the United States and China to avoid war in their own relationship needs mentioning here. Moreover, evidence of threats of force are not difficult to find. In the last few years, the United States, alongside its allies Japan and Australia, have accused China of using coercion to change the maritime status quo in East Asia, in both the South and East China Seas. Whatever the merits of these claims, it must be accepted that Washington cannot, and does not, accuse Beijing of using violent force, including actual hostilities, to achieve its foreign policy objectives. And few expect major war between the United States and China to be around the corner, even if some feel the tensions between them are growing. 
Similarly, an often overlooked fact is Washington's reliance on coercion to achieve its strategic objectives in Asia, including, if we are to believe the implied messaging, to protect the status quo. That coercion includes the United States' freedom of navigation patrols, its extended deterrence commitments to key regional allies and its strengthening of defence cooperation with South Korea to forestall a greater challenge from North Korea. This coercion also includes the United States' direct deterrence of China (and vice versa). There is all manner of signalling going on here.

This coercion on the part of China and the United States is not one of Hedley Bull's accidents of history. It is conscious activity designed to influence the expectations and behaviour of the other side, and to influence the expectations and behaviour of others in the region. There is enough evidence to suggest that China and the United States wish to avoid war in their relations and to keep any sabres rattling rather than brandished in an actual engagement. There is also enough evidence to suggest that they can work together to manage the interaction of their coercionthink of their cooperation after the EP-3 spy plane incident and the now fairly regular management of some fairly hairy moments on the high seas. But it is a bit less clear how well they are able to manage their coercive interactions in a properly heated bilateral crisis. An adverse partnership requires a measure of crisis stability that we might wonder about.

One of the reasons for these concerns is connected to the fourth factor: that the Cold War adverse partners had seen the abyss in the Cuban Crisis and were aware what was at stake should their conflict not be managed. That abyss was created by an intense competition for nuclear parity that we do not see in the more asymmetric US-China nuclear interaction. I do not want the United States and China to be more scared of one another than they need to be, but you have to wonder whether they are quite scared enough. Despite all of their economic interactions, I am just not sure how much Washington and Beijing both believe that they must see each other as partners as well as competitors in their security interactions in Asia today. And I wonder whether they see an adverse partnership as completely necessary. Are they more inclined to think that they can press on with their aims - which for the United States includes the maintenance of regional primacy and which for China includes challenging that status quo-without worrying quite as much as we would want them to about the risks of that behaviour? It is a concern of this sort that I think led 
Hugh White towards his China Choice. ${ }^{18}$ There, his sharing of power argument strikes me as more ambitious than Coral's adverse partnership, based as the latter is on a similar recognition that there are common as well as competitive interests between the two.

What about the rest of us in the Asia Pacific, or, as Australia now likes to say, the Indo-Pacific? There is no doubt that the fifth factor applies: that the wider region depends heavily on the ability of China and the United States to mix a bit of partnering with their competition. In Asia's Security, I was looking for those factors that linked the wider region together in security terms. I did this to allow us to talk about the security of Asia rather than just security somewhere in the region. My assessment, which should probably not surprise any of us, is that the China-US strategic interaction was the most important of these system-wide factors. ${ }^{19}$

This raises a further question. If the extent and quality of the China-US adverse partnership affects the rest of us, what does this mean in reverse? How much impact can we have through our own choices on the quality of their interaction? If an adverse partnership is in essence a way of managing conflict, what role do third parties have in helping that management? Is there more room today than there was in the Cold War for that to be happening? If the answer is yes, we had better get our strategic skates on.

\section{Conclusion}

My final point here is that the idea of an adverse partnership can do more than tell us a good deal about the US-Soviet strategic interaction during the Cold War. And it can do even more than offer us some good questions to ask about great power strategic relations today. I think the adverse partnership idea tells us a great deal about the nature of our subject. It can remind us what strategic studies is about. I say this because at the heart of the adverse partnership is the management of conflict. Schelling's book, still hugely influential, is The Strategy of Conflict. But while Strategy as Conflict Management might not sound fantastic as an alternative title, I think it could be closer to home.

18 See Hugh White, The China Choice: Why America Should Share Power, Black Inc., Melbourne, 2012.

19 See Robert Ayson, Asia’s Security, Palgrave Macmillan, London, 2015. 
Strategy is not only the management of war, which is a subset of conflict. It is not the mere study of conflict, because, as Brodie once said, 'strategy is a theory for action. ${ }^{\prime 20}$ It is not just the pursuit of ends through available means, because to manage conflict is to have a deliberate influence on other actors in our interactions with them. Strategy is therefore much more than the use of conflict and threats of conflict. It is the conscious regulation of conflict as a fact of international life, whether in wars hot or cold or somewhere in between. 


\section{7}

\section{Beyond 'hangovers': The new parameters of post-Cold War nuclear strategy}

\section{Nicola Leveringhaus}

We are now more than a quarter-century into the post-Cold War period. Yet vestiges of a 'Cold War mentality' are said to remain, limiting our understanding of nuclear strategy today. For some, concepts and capabilities specifically developed with US and Soviet nuclear strategy in mind, such as mutual assured destruction (MAD) as an optimal strategic condition or a Second Strike Force, have become conceptual 'hangovers' that strategists have struggled to improve upon, leaving little room for innovation in the nuclear domain. ${ }^{1}$ This chapter seeks to push back at this 'hangover' narrative by drawing out global developments that have shaped thinking about nuclear strategy since 1990. It will also be argued that the global conditions under which nuclear strategies have been formulated are fundamentally different post-1990. This might seem a rather uncontroversial statement. Most would agree that, compared to the Cold War period, the prospects of nuclear war are thankfully much reduced today. However, there are relatively few academic accounts of how nuclear strategies have developed since $1990 .^{2}$

1 For a longer elaboration of this hangover narrative, see Vipin Narang, Nuclear Strategy in the Modern Era: Regional Powers and International Conflict, Princeton University Press, Princeton, 2014, pp. 1-3.

2 An important exception is work by Lawrence Freedman. Recent editions of his seminal Evolution of Nuclear Strategy reflect changes in the post-Cold War period up to the early 2000s. See Lawrence Freedman, The Evolution of Nuclear Strategy, 3rd edn, Palgrave Macmillan, London, 2003. 
This chapter proceeds in a chronological manner to give a sense of time. The post-Cold War era problematically suggests a monolithic period forever tied to the Cold War. The chapter will therefore break down this era into set periods that have shaped the conditions under which different nuclear strategies have emerged. The first starts with the immediate period after the fall of the Union of Soviet Socialist Republics (USSR) and the emergence of the United States as the sole superpower (from 1990 to 1997). This is a period in which nuclear strategy seems to take a back seat on global nuclear agendas. The second and main part of the chapter focuses on the period from the late 1990s to the mid-2000s. Transitions in the wider global order have important implications for nuclear strategy during this period-in particular, the emergence of regional centres of power, rogue powers and hostile non-state actors. The final part of the chapter turns to the late 2000s and developments that have, whether intentionally or not, begun to shape how we think about nuclear strategy and nuclear deterrence. Ultimately, it will be argued that since the 1990s, broader global developments have directly or indirectly shaped what is politically acceptable as well as militarily desirable and possible when devising nuclear strategies worldwide.

\section{Early post-Cold War: Nuclear safety, not strategy}

The break-up of the Soviet Union signalled major change on the global nuclear front. In December 1991, the USSR disintegrated into 15 newly independent states. The Soviet nuclear arsenal scattered with many parts unaccounted for across Russia, Ukraine, Belarus and Kazakhstan. The immediate nuclear challenge at the end of the Cold War was therefore proliferation based rather than focused on how best to design nuclear strategy in the post-Cold War world order. ${ }^{3}$ To address the problem of Soviet 'loose nukes', the Cooperative Threat Reduction Program was launched by the United States in 1991. By 1996, all three former Soviet republics were denuclearised.

3 Gilles Andreani, 'The disarray of US non-proliferation policy', Survival 41, no. 4, 1998, pp. 42-61. 
Beyond efforts to secure Soviet nuclear weapons, a succession of arms control and non-proliferation initiatives were signed in the early to mid-1990s. Russian and US Strategic Arms Reduction Treaty (START I) negotiations were accelerated; a testing moratorium was established that led to the Comprehensive Test Ban Treaty (CTBT) signed in 1996, and production of new nuclear weapons halted. In addition, in 1993 a program (what would in 1997 become the Additional Protocol) was initiated to strengthen international nuclear safeguards, and in 1995 the Non-Proliferation Treaty (NPT) - the most powerful legal framework prohibiting the spread of nuclear weapons - was indefinitely extended. Elsewhere, China joined the NPT in 1992 and the CTBT in 1996; South Africa unilaterally gave up its nuclear program and joined the NPT in 1991. All in all, the early to mid-1990s represented a golden era for strengthening global legal and institutional frameworks around arms control and non-proliferation.

While arms control and non-proliferation were centre-stage, nuclear deterrence- the cornerstone of mainstream strategic thinking concerning nuclear weapons in the Cold War-was branded passé and looked likely to lose relevance fast. ${ }^{4}$ Addressing the US-USSR nuclear relationship in a 1995 statement to Congress, the then US Secretary of Defence William Perry argued, 'We now have the opportunity to create a new relationship based not on MAD but rather on another acronym, MAS, or Mutual Assured Safety'. Several academic and policy studies from the 1990s onwards were tasked to consider how many nuclear weapons were necessary to maintain effective deterrence as a clear threat (e.g. the Soviet Union) was no longer the driver for formulating nuclear strategy in the United States. ${ }^{6}$ A 1995 US report recommended that US nuclear weapons policy be clear on the negative consequences of a nuclear response but ambiguous on the details of the actual response. ${ }^{7}$

4 Austin Long, Deterrence-from the Cold War to the Long War, RAND, Santa Monica, 2006; on this, see also Theresa Delpech, Nuclear Deterrence in the 21st Century: Lessons from the Cold War for a New Era of Strategic Piracy, RAND, Santa Monica, 2012. Russia was an exception in some respects, abandoning 'no first use' in 1993.

5 William Perry, 'Pursuing a strategy of mutual assured safety', remarks at the National Press Club, Washington, DC, by the US Secretary of Defense, 5 January 1995.

6 I.C. Oelrich, 'Sizing post-Cold War nuclear forces', Institute for Defense Analysis Paper P-3650, October 2001.

7 Policy Subcommittee of the Strategic Advisory Group, 'Essentials of post-Cold War deterrence', 1995, www.nukestrat.com/us/stratcom/sagessentials.htm (retrieved 29 January 2018). 
Academia, for its part, was also losing interest in nuclear strategy. As such scholars as Vipin Narang highlight, ${ }^{8}$ by the late 1980s and early 1990s, intellectual consensus around existential deterrence started to build. According to this consensus, an existential nuclear threat based on one or two nuclear bombs was enough to deter, rending strategy somewhat irrelevant. Other developments in academia pushed strategy to the back seat. Philosophers, for instance, perhaps cheered by the reduced salience of nuclear weapons post-1990 (and the lower prospect of nuclear war more generally), almost completely abandoned intellectual conversations concerning the ethics of nuclear deterrence and technologies like missile defence. (Sadly, philosophers have yet to return to the nuclear field.) ${ }^{9}$ Shockingly, nuclear ethics therefore has had almost nothing to say about strategy since 1990. Nuclear strategy was not abandoned in political science or international relations, but a decisive shift began in the 1990s away from strategy towards non-proliferation as the main area of study in the nuclear subfield. This overwhelming interest in limiting proliferation continues even today. ${ }^{10}$

Nuclear strategy had to face an additional, unforeseen, challenge in the early post-Cold War period: namely, the military significance of the so-called US 'unipolar moment'. With the fall of the USSR, the United States enjoyed unrivalled military prowess as the world's only superpower. This prowess was on dramatic display both during the 1991 Persian Gulf War and later the 1995-96 Taiwan Strait Crisis. US military technologies used in these operations, together with US work on missile defence in the 1990s, heralded a 'revolution in military affairs' (RMA). The RMA represented a major wakeup call for some countries such as China, highlighting a serious gap in their advanced weapons capabilities relative to the United States. ${ }^{11}$ More crucially for nuclear strategy, unrivalled US conventional military power reflected

$8 \quad$ Narang, Nuclear Strategy in the Modern Era, pp. 1-3.

9 However, in the late 2010s there have been calls, led by Thomas E. Doyle III ('Reviving nuclear ethics: A renewed research agenda for the twenty-first century', Ethics and International Affairs 24, no. 3, 2010, pp. 287-308), for a return to nuclear ethics.

10 Academic interest in non-proliferation has benefited in particular from a broader turn towards quantitative methods in political science as well as an increasingly global study of nuclear proliferation history (beyond the United States and Soviet Union) since the 1990s. Work by the Wilson Center's International Non-Proliferation History Project stands out in this regard, as does individual work by such academics as Matias Spektor on Brazilian nuclear history, for instance.

11 On this Chinese reaction, see Nicola Horsburgh, China and Global Nuclear Order: From Estrangement to Active Engagement, Oxford University Press, Oxford, 2015. 
a new reality for the post-Cold War age: with advanced conventional superiority there was no need for the United States to be tied to the old logic of MAD.

Summarising, several developments in the early post-Cold War period shaped, either directly or indirectly, thinking about nuclear strategy. The first started with the end of the USSR, which led to a focus on nonproliferation and a shift away from strategy. This shift away from strategy towards non-proliferation occurred in academic circles too. The second important change concerns US military power with the 1991 Persian Gulf War and the 1995-96 Taiwan Strait Crisis demonstrating two lessons for strategy: first, a glaring gap in capabilities between the United States and other states, and second, a growing role for advanced conventional technologies (as opposed to nuclear weapons) in military strategy.

\section{The return of nuclear strategy}

Nuclear strategy did not remain in the back seat for long. ${ }^{12}$ By the late 1990s, a number of nuclear incidents pushed strategy back on to the agenda. In 1998, India and Pakistan exploded nuclear devices and refused to join the NPT. In July 1998, Iran launched a Shahab-3 missile and, in August, North Korea tested a long-range Taepodong missile. Terrorist threats also increased following attacks on US embassies in Kenya and Tanzania that year, and eventually the tragic 9/11 terrorist attacks on New York and Washington, DC, in 2001. The United States in particular feared terrorist groups' acquisition of weapons of mass destruction, and this prompted Washington to emphasise counterproliferation and pre-emption, overshadowing its previous focus on safety issues and non-proliferation. ${ }^{13}$

Beyond these headline news events, there have been broader shifts underway in the global order with indirect implications for nuclear strategy. Two are explored here: (1) the rise of what Andrew Hurrell has

12 This section draws significantly on Narang, Nuclear Strategy in the Modern Era, and an article I co-authored: Nicola Leveringhaus and Kate Sullivan de Estrada, 'Between conformity and innovation: China's and India's quest for status as responsible nuclear powers', Review of International Studies 44, July 2018, pp. 482-503, doi.org/10.1017/S0260210518000013.

13 Andreani, 'The disarray of US non-proliferation policy', p. 46. 
called 'regional forms of nuclear order'; ${ }^{14}$ and (2) the security threat posed by rogue actors, especially North Korea and non-state actors such as al Qaeda.

The significance of the first shift for nuclear strategy requires some unpacking. The nuclear field has largely focused on strategy at a global level-that pertaining to rival great powers rather than a comparative study of regional-level nuclear strategies involving rising states. ${ }^{15}$ An exception is work cited here by Vipin Narang on South Asia more broadly, ${ }^{16}$ where the Indian-Pakistani rivalry has focused strategic thinking on confidence-building to reduce the likelihood of nuclear conflict. Yet the proliferation of regional forms of nuclear order is evident elsewhere too, such as the case of South America where rivals Argentina and Brazil cooperated in the 1990s to secure a nuclear order based on the goal of nuclear disarmament. In North-East Asia, continuing North Korean nuclear activities have moved the regional nuclear agenda towards non-proliferation and nuclear security as well as focusing on missile defence. Regional missile defence has proved especially relevant in shaping China's restrained nuclear strategy since the 1990s. China, a rising power with a small nuclear arsenal that is not on high alert, has focused on modernising its arsenal so that it remains secure and credible. Beijing has also sought to secure a role in the regional-ordering process by hosting the Six Party Talks and establishing a regional centre for nuclear security. What is a concern for this chapter is that these regional forms of nuclear order have their own sets of priorities and interests, to include rising or re-emerging powers eager to have a stake in the nuclear-ordering process.

To put it bluntly, regional forms of nuclear order have become increasingly powerful and distinct diplomatic platforms from which to manage nuclear weapons. They also condition the direction and depth of nuclear strategies.

14 This specific term was used by Hurrell in a draft paper presented to the Global Nuclear Order workshop organised by the US Academy of Arts and Social Sciences at the University of Oxford in September 2015. For more on regions and how they interact with global order, see Andrew Hurrell, On Global Order, Oxford University Press, Oxford, 2010.

15 In general, the nuclear field has shied away from comparative and regional studies. Exceptions include work by Etel Solingen, who compares regional cases of proliferation in her Nuclear Logics: Contrasting Paths in East Asia and the Middle East (Princeton University Press, Princeton, 2007) as well as Robert Ayson's article comparing institutions in the non-proliferation regime, 'Selective nonproliferation or universal regimes?', Australian Journal of International Affairs 59, no. 4, 2005, pp. 431-7. Doctoral work in 2012 by Francesca Giovannini at the University of Oxford specifically examined the role of regional nuclear politics.

16 For instance, see Narang's Nuclear Strategy in the Modern Era, or the excellent work by Paul Kapur and Samit Ganguly on India and Pakistan. 
During the Cold War, the simpler (although perhaps far deadlier) nature of the nuclear game was that it existed largely at a global rather than regional level and was determined by two superpowers armed with nuclear weapons-namely, the United States and the Soviet Union. These two superpowers, together at times with the United Kingdom, spearheaded the development of major institutions and norms of the global nuclear order. However, since the 1990s, the task of managing these weapons has become more complex. Tackling nuclear proliferation crises-the Six Party Talks on the Korean Peninsula in the mid-2000s or the Iranian July 2015 deal, for example_-requires the participation of multiple regional stakeholders. Crudely put, the logic of MAD and superpower politics is no longer the glue that holds nuclear order together. In its place, we have regional forms of nuclear ordering (with specific interests and capabilities that might or might not converge with one another) competing with global norms, treaties and institutions established in the Cold War era.

The second shift-that involving rogue states and hostile non-state actors-has perhaps more evident implications for nuclear strategy. ${ }^{17}$ These actors arguably enhance the prospects of nuclear terrorism to a higher degree than during the Cold War. Rogue actors like North Korea and non-state terrorist groups like al Qaeda operate outside global nuclear institutions. In these circumstances, knowing how your enemy works and developing a strategy that is credible and easy to communicate becomes a practical challenge. These actors are also considered irrational, willing to endure higher costs and more likely to use the bomb if they manage to attain this capability. This presents real challenges for the nuclear strategist, begging the question: how can one credibly deter such an actor?

\section{Racing towards credibility}

The shifts above point to a common trend underlying post-Cold War nuclear strategy in the late 1990s, namely the pursuit of credibility. Apart from the United States, almost all the nuclear-armed states in the late 1990 s and early 2000s had their respective reasons for pursuing credibility. India and Pakistan, testing in 1998, had the most obvious reasons for seeking credibility. They were new nuclear actors and needed to come

17 These actors present real concerns for proliferation as well, of course. They undermine nonproliferation through participation in illicit nuclear smuggling, such as the infamous AQ Khan network uncovered in 2004. 
up with a nuclear strategy for the first time. In the late 1990s and early 2000s, China finally decided to embrace nuclear deterrence publicly (it had consistently denounced nuclear deterrence since testing in 1964). China's modernisation program was also starting to bear more credible fruit from the early 2000s onwards. In particular, China secured its landbased missiles (e.g. the DF-31 and DF-31A) by making them more mobile and made progress on a submarine-launched ballistic missile capability. Russia, having lost a significant portion of its Soviet nuclear arsenal at the end of the Cold War, as well as the economic resources to maintain it, had a credibility deficit too. This resulted in a number of changes to its nuclear strategy, including abandoning 'no first use' (NFU) in 1993 and relying more on nuclear weapons rather than conventional forces in its military strategy in the 2000s. ${ }^{18}$ Israel, an opaque undeclared nucleararmed state, saw not the end of the Cold War but the 1991 Persian Gulf War as a turning point for its decision to pursue a more credible nuclear strategy, one less reliant on the patronage of the United States.

For India, China and Israel, a credible nuclear strategy has rested on the twin goals of retaliation and restraint. This entails securing largely rudimentary retaliatory capabilities not to be confused with a secondstrike capability (a Cold War concept). Unlike Cold War strategies, these basic retaliatory postures have regional rather than global force projections in mind. Important distinguishing elements of these postures include the prioritisation of (a) improving mobility for missiles, something China and India, as well as North Korea, have pursued to ensure their survivability; (b) ambiguity over the terms of use (first/no first use, alert status); and (c) uncertainty over the numbers (and types) of weapons under development. For China and India, nuclear restraint and minimalism were promoted as important markers of their respective nuclear strategies based on NFU and a de-alerted small nuclear arsenal. Both countries sought to highlight their differences compared to the superpowers that had invested in developing vast arsenals in order to secure deterrence. For China and India, vast arsenals employing a Cold War-style triad (involving air, sea and land launch platforms) is not the goal. Instead, one or two platforms suffice.

18 The National Security Concept was released in 2000. Reliance on nuclear weapons until conventional weapons were modernised was reaffirmed in the report. See F. Umbach, 'Russia's changing threat perceptions', International Politik 4, no. 1, 2003, pp. 53-7. See also Nikolai Sokov, 'Russian nuclear strategy: Background, current status, future', Center for Nonproliferation Studies presentation, www.nonproliferation.org/wp-content/uploads/2016/06/Nikolai-Sokov-Russian-Nuclear-Strategy.pdf (retrieved 29 January 2018). 
The United Kingdom, like France, did not drastically alter its nuclear strategy in the 1990s and 2000s. Instead, it decreased its reliance on nuclear weapons with a vast reduction in the size of its nuclear arsenal throughout this period. ${ }^{19}$ France, for its part, sees credibility in more certainty regarding the terms of its nuclear use, stating it would use nuclear weapons in response to nuclear or non-nuclear attack. Russia and Pakistan place similar credibility in the first use of nuclear weapons.

The United States is the exception here. Since the 1990s, Washington has not sought credibility nor has it pursued old nuclear relationships built around MAD. Washington has instead focused on retaining the nuclear superiority it gained as the sole superpower after the Cold War. What precisely 'retaining' superiority means for US nuclear strategy seems to shift over time. Its first official outing was under President Clinton with a 'Lead and Hedge' strategy outlined in $1997 .{ }^{20}$ Since then, minimum and maximum versions of retaining nuclear superiority have emerged. A maximum retaining capability (entailing more usable and accurate nuclear weapons teamed up with advanced conventional technologies such as missile defences) seemed popular following the 2001 nuclear posture review. At the time, in 2001, then President Bush stated that 'Cold War deterrence is no longer enough ... It is time for a new way of thinking'. ${ }^{21}$ This included a need to 'refashion the balance between defences and deterrence'. ${ }^{22} \mathrm{~A}$ minimum version of retaining nuclear superiority, which leaves more room for arms control and speaks to the aspirational and cooperative idea of a shared 'strategic stability' with Russia and China, emerged during the Obama Administration. Debates even took place over sole use in the run-up to the 2010 nuclear posture review. The retaining superiority debate in US nuclear strategy remains unresolved even today.

19 For the official UK nuclear policy on nuclear weapons since 2010 see UK Ministry of Defence, '2010 to 2015 Government Policy; UK Nuclear Deterrent', www.gov.uk/government/ publications/2010-to-2015-government-policy-uk-nuclear-deterrent/2010-to-2015-governmentpolicy-uk-nuclear-deterrent (retrieved 4 March 2018).

20 Willian Arkin and Hans Kristensen, 'Dangerous directions', Bulletin of Atomic Scientists 52, no. 2, 1998, pp. 26-31.

21 George W. Bush, 'Speech on missile defence', at the National Defense University, Washington, DC, 1 May 2001, fas.org/nuke/control/abmt/news/010501bush.html (retrieved 29 January 2018).

22 Jim Garamone, 'Rumsfeld details DoD goals, objectives in testimony', Department of Defense, Washington, DC, 12 January 2001, archive.defense.gov/news/newsarticle.aspx?id=45149 (retrieved 29 January 2018). 
In summary, shifts in global order, especially the emergence of regional forms of nuclear order and hostile non-state actors, have important implications for formulating post-Cold War nuclear strategy. The pursuit of credibility emerged as an urgent task for nuclear actors with the exception of the United States (intent upon maintaining nuclear superiority). For some nuclear armed states, credibility is based not on assured destruction or even second-strike capabilities, but on rudimentary retaliatory capabilities with regional projections in mind. For France, Russia and Pakistan, certainty over the use of force is more important.

\section{Late 2000s: delegitimising and de-emphasising the bomb}

In the late 2000s, a number of global developments have, intentionally or otherwise, chipped away at the role nuclear weapons might play in future military strategy. Two will be discussed here. The first development refers to a series of high-level policy initiatives that reinvigorated the disarmament agenda and deliberately sought to delegitimise the bomb. The second development concerns discussions in military and strategic circles regarding 'cross-domain deterrence' and whether this formulation of deterrence might indirectly de-emphasise the role of nuclear weapons in overall military strategy.

Momentum behind the delegitimisation of nuclear weapons began to build from 2009 onwards when US President Obama launched what has now become known as the 'Prague Agenda', a set of goals to reduce the number of nuclear weapons worldwide and restart arms control, especially with Russia. ${ }^{23}$ Major aspects of this initiative included three important developments by April 2010: revised US nuclear ballistic missile defence and space posture reviews, a new START (Strategic Arms Reduction Treaty) between the United States and Russia, and the first global Nuclear Security Summit. Taken together, these initiatives signalled a possible return to arms control through strategic stability dialogues with Russia and China and the nuclear security summits. A second initiative, not to be confused with Obamas Prague Agenda, also emerged in the late 2000s, one calling for a more transformative 'nuclear weapons free

23 Obama used the term in a speech in Prague on 5 April 2009. 
world', or 'Global Zero'. ${ }^{24}$ Around this time, a third initiative emerged, focused on the humanitarian impacts of nuclear weapons. Initially a factbased initiative, the Oslo Conference on Humanitarian Effects of Nuclear Weapons was held from 4 to 5 March 2013. Subsequent meetings in Mexico in February 2014 and Vienna in December 2014 have focused less on scientific studies of the humanitarian effects of these weapons and more on the pursuit of a weapons ban.

Of these initiatives, the Prague Agenda has had much wider global appeal among governmental elites in most nuclear weapons states than the campaign for a nuclear weapons-free world. The humanitarian impact agenda has become a popular venue for non-nuclear weapons states and especially non-government organisations, which have long campaigned for global disarmament. However, none of these initiatives have led to substantive change in terms of nuclear strategy; despite these efforts, nuclear deterrence remains a cornerstone of all nuclear-armed national security policies, including that of the North Atlantic Treaty Organization (NATO). Even in the United Kingdom, where domestic debate has raged around renewing its nuclear deterrent Trident, there seems to be little if any prospect of disarmament.

The second development, which has some potential to transform nuclear strategy, is cross-domain deterrence. This concept was not unheard of during the Cold War, yet it has become more evident in the post-Cold War era. Strategists worldwide have been concerned about the implications of cyber- and outer-space technologies and how they can be combined with nuclear weapons to strengthen rather than undermine deterrence. ${ }^{25}$ In the United Kingdom, discussions are going on around what it terms 'full spectrum deterrence'. The idea is to have dominance over a number of domains; not just cyber, space and nuclear but also international law, diplomacy and influence over the global economy. Outside the West, China is making significant inroads in developing cross-domain deterrence. According to Brad Roberts, cyber warfare is a key element of an overall 'theory of victory' in Chinese military strategy beyond nuclear

24 George Schultz, William Perry, Henry Kissinger and Sam Nunn, 'Toward a nuclear-free world', Wall Street Journal, 15 January 2008, www.nti.org/media/pdfs/NSP_op-eds_final_.pdf?_= 1360883065 (retrieved 29 January 2018).

25 Martin Libicki, Cyberdeterrence and Cyberwar, RAND Corporation, Santa Monica, 2009; on space deterrence, Robert Butterworth and John Sheldon, Deterrence in Space: Responding to Challenges to the US in Outer Space, George Marshall Institute, Washington, DC, November 2008. 
deterrence. ${ }^{26}$ Whatever China's overall strategic goal, recent changes under President Xi Jinping, such as a new military force dedicated to cyber and space (the People's Liberation Army (PLA) Strategic Support Force), suggest that it envisages scenarios in which cross-domain deterrence is in play. Ultimately, it remains unclear what this type of deterrence means for nuclear strategy. Does it render, or threaten to render, nuclear deterrence redundant, as some argue, ${ }^{27}$ or simply form part of a suite of deterrence capabilities? Whatever the answers, these domains are likely to matter because they have become more prominent than they ever were during the Cold War.

\section{Conclusion}

This chapter has identified a set of distinctive features in the post-1990 environment that have directly or indirectly shaped nuclear strategy. Initially, at the end of the Cold War, the dissolution of the USSR and the threat of 'loose nukes' forced nuclear strategy to take a back seat on global nuclear agendas. The early to mid-1990s instead became a golden era for arms control and non-proliferation wherein several treaties and initiatives were established or strengthened. In academia, too, nuclear strategy lost favour, and studies turned to proliferation puzzles rather than questions of modern strategy. Even philosophers, no longer concerned about superpower nuclear war, abandoned the ethical dilemmas posed by nuclear weapons. Moreover, during this period, US conventional weapons and the so-called RMA—not nuclear weapons-were all the rage. US military capabilities on display in the 1991 Persian Gulf War and later the 1995-96 Taiwan Strait Crisis signalled a glaring gap in capabilities between the United States and other nuclear weapons states like Russia and China. More broadly, US military prowess sent a clear message for nuclear strategy: the days of MAD as a guide for strategy were over.

26 Brad Roberts, The Case for US Nuclear Weapons in the 21st Century, Stanford University Press, Stanford, 2016, p. 165.

27 James E. Goodby, 'The nuclear dilemma: Constants and variables in American strategic policies', in The War That Must Never Be Fought: Dilemmas of Nuclear Deterrence, ed. George P. Shultz and James Goodby, Hoover Institution Press, Stanford University, 2015, pp. 69-71, www.hoover.org/sites/default/ files/research/docs/goodby_shultz_-_the_war_that_must_never_be_fought_-_scribd.pdf (retrieved 4 March 2018). 
Nuclear strategy had returned to national security agendas by the late 1990s. Two important developments in the broader global order enabled and facilitated this process. The first development concerns 'regional forms of nuclear order'. Regional nuclear orders have emerged with their own interests and capabilities, and this is a distinctive feature of the postCold War environment. As a result, nuclear strategies have increasingly developed through a regional rather than global lens, as was the tendency during the Cold War. The second development relates to hostile non-state actors and rogue states. Deemed difficult to deter, they continue to pose a serious problem for modern nuclear strategy.

Eventually, the pursuit of credibility emerged as a key driver for nuclear strategy in the 1990s. Credibility has come in different forms for different nuclear-armed states. For some, such as China and India, strategies have been built around notions of restraint and minimalism, while others have moved towards more unilateral forms of deterrence. Russia, France and Pakistan increasingly rely on their nuclear arsenals; other nucleararmed states have sought to reduce their reliance on nuclear weapons. The United States is the exception. Rather than credibility, it has focused instead on retaining superiority in its nuclear strategy since the 1990s. Despite developments in the late 2000s around Global Zero and the humanitarian impact initiative, including efforts to pursue cross-domain deterrence, credibility remains the baseline for most nuclear strategies. Ultimately, nuclear strategy has come a long way since 1990. From the back seat of global agendas and intellectual disinterest, nuclear strategy has developed in the context of regional forms of nuclear order and the pursuit of credibility. 



\section{8 \\ The return of geography}

\section{Paul Dibb}

The title of this chapter might suggest that geography has somehow gone missing in action as a body of strategic knowledge. While it is true that some theoreticians bought the superficial view at the end of the Cold War that geography had had its day, that was never the view of those of us who were senior defence policy officers. Strategic theories come and go, but the abiding nature of a nation's geography remains a key defence planning tool. Indeed, I would agree with Australia's greatest Secretary for Defence, Sir Arthur Tange, who said in 1986: 'The map of one's own country is the most fundamental of all defence documentation. ${ }^{1} \mathrm{He}$ also presciently asserted that the nature of Australia's physical environment demands that maritime capabilities occupy a prominent place in defence. ${ }^{2}$

None of this is to argue that I am a geographical determinist, as some would have it. Geography clearly varies according to a nation's strategic circumstances and, importantly, its perceptions of threat or the lack of one. Geography operates for Australia as a crucial consideration when it comes to the defence of the continent and the location of the archipelago to our immediate north. As Robert Kaplan argues in his book The Revenge of Geography, we all need to recover sensibility about the relevance of geography that has been lost in the current era when

1 Sir Arthur Tange, Defence Policy Administration and Organisation: Selected Lectures 1971-1986, Australian Defence Force Academy, University of New South Wales, Canberra, 1992, p. 90.

2 Ibid., p. 74. 
some commentators-such as the New York Times columnist Thomas Friedman—talk glibly about a flat world where geography no longer matters. ${ }^{3}$ As Kaplan notes, the end of the Cold War led to a mistaken view that globalisation and economic interdependence would inevitably lead to the end of geopolitical rivalries among great powers and to the emergence of a more enlightened liberal order. ${ }^{4}$ Others argue that modern military technology has effectively cancelled geography, which, as Colin Gray observes, has just enough merit to be a plausible fallacy. ${ }^{5}$ Despite trendy talk of a 'borderless world', the control of territory is still fundamental to world politics.

As the longest serving former Head of the Strategic \& Defence Studies Centre (SDSC), I thought it appropriate for this 50th anniversary essay to address the role of geography conceptually in the following areas of my current work: first, the importance of geopolitics in Putin's Russia and Moscow's challenge to established borders in Europe; second, China's territorial ambitions-especially in the South China Sea, which has been described by the Chancellor of this university as the most dangerous strategic issue in our region; third, the renewed importance of Australia's geographical location and its relevance to the US 'pivot' to Asia.

I see these three issues in the broader context of what I fear is a dangerous era unfolding strategically at the global level. In my view, we have two large authoritarian powers-China and Russia—challenging the liberal international order led by the United States and its democratic allies at a time when domestic politics in the West are in disarray over the impact of globalisation. Now is not the time for the West to be preoccupied domestically just when China and Russia are issuing challenges to the established order and flexing their military muscles.

\section{Geopolitics and Russia today}

First, then, let us turn to the geographic ambitions of a resurgent Russia. ${ }^{6}$ They exist at two levels: to reassert Russia as a great power (velikaya derzhava) and to recover lost territories. Putin is determined to

\footnotetext{
3 Robert D. Kaplan, The Revenge of Geography, Random House, New York, 2012, p. xix.

4 Ibid., p. 4.

5 Quoted in ibid., p. 33.

6 For a more detailed exposition of these views see Paul Dibb, "Why Russia is a threat to the international order', Australian Strategic Policy Institute Strategy paper, June 2016.
} 
recover Russia's standing in the Eurasian geopolitical space. As former British Ambassador to Russia Roderic Lyne explains, President Putin's 'new model Russia' is that of an independent great power resuming its geopolitical position on its own terms. Lyne states that this reflects a deep sense of insecurity and a fear that Russia's interest would be threatened if it were to lose control of its neighbourhood.7 Putin speaks of Russia's civilising mission on the Eurasian continent. He claims the right to a sphere of strategic interest in Russia's neighbourhood in which Western influence and involvement would be limited. That sphere includes not only Crimea and Ukraine but also the Baltic countries, Belarus, Moldova and northern Kazakhstan. Putin's Russia is set on a path of confrontation with the West and is now challenging the established post-World War II security order in Europe. The Chairman of the US Joint Chiefs of Staff, General Joseph Dunford, has described Russia as presenting 'the greatest threat to our national security', and US Defense Secretary Ashton Carter has accused Russia of endangering world order and making threatening statements about its potential use of nuclear weapons. Indeed, the use of tactical nuclear weapons now figures prominently in Russia's new military doctrine. ${ }^{8}$ Moreover, Moscow is now capable of deploying 150,000 troops with little or no warning, probably under the disguise (maskirovka) of a major exercise, into any of the countries of its near abroad. This is not to argue that Russia has recovered the military power of the former Soviet Union. It has not, but it needs to be remembered that, from Putin's perspective, Russia faces a weak and divided Europe. And it is a fact that most Russians do not accept that there can be such an independent state as Ukraine.

Putin paints a picture of Russia as a victim and target of Western attack over the centuries with the West constantly trying to destroy it. Nikolai Patrushev, the head of Russia's Security Council and a KGB veteran, accuses the United States of wanting Russia to cease to exist as a nation, and Sergei Naryshkin, a close Putin ally and speaker of Russia's lower house of parliament, suggests that the United States is trying to goad Russia into war. ${ }^{9}$ These are obsessive assertions with little basis in fact and are more a reflection of centuries of Russia's paranoia about the

7 Roderic Lyne, 'Russia's changed outlook on the West: From convergence to confrontation', in The Russian Challenge: Chatham House Report, Royal Institute of International Affairs, London, June 2015, p. 11.

8 Dibb, 'Why Russia is a threat to the international order', p. 11.

$9 \quad$ Ibid., p. 8. 
vulnerability of its borders and its insecurity as a nation-state. But we ignore them at our peril. And I am not one of those who accept that the weakness of Russia's economy will make Putin more cautiousrather the opposite. What we have been seeing of late are many highly disturbing incidents by Russia involving violations of North Atlantic Treaty Organization (NATO) countries' national airspace, narrowly avoided mid-air collisions, close encounters at sea, simulated attack runs with nuclear-capable aircraft and other dangerous actions on a regular basis over a very wide geographical area, including the Baltic, Black and North Seas, the Arctic and along the US and Canadian borders. Moscow has used military force to recover territory in Georgia and Crimea and is destabilising Ukraine by its occupation of the Donbass. And in Syria, we saw in 2015 Russia's first use of military power outside the former Soviet security sphere. This marked Putin's reassertion of Russia's military power and his retaliation for the expansion of NATO to Russia's borders through his own use of military force in Syria on the borders of a NATO member, Turkey. Russia's military intervention in Syria had a decisive effect and gained it a place at the negotiating table, ensuring that the United States can no longer ignore Moscow's interests in the Middle East.

Many Western observers have consistently misread Russia and the way it is driven by its geography, history and culture. One of the problems here is that insufficient attention has been paid in the West to the evolution of Russian military thinking in the post-Cold War period. A recent Chatham House research paper states that Western policy-makers' grasp of the Russian leadership's motivations and decision-making processes, and especially in respect of military matters, has been degraded.${ }^{10}$ Current Russian ambitions, followed to their conclusion, will inevitably lead to a more direct confrontation with the West. Russia's political will to resort to force when necessary seems to be entirely absent in Europe these days. Managing the increasing threats Russia poses to international order is now arguably the most serious issue facing the West. This is not to underestimate the challenge emanating from a rising China, but Chinaunlike Russia - does not pose a potential existential threat to world peace in the same way.

10 Andrew Monaghan, 'A new "Cold War"? Abusing history, misunderstanding Russia', research paper, Russia and Eurasia Programme, May 2015, Royal Institute of International Affairs, Chatham House, London, www.chathamhouse.org/sites/files/chathamhouse/field/field_document/20150522 ColdWarRussiaMonaghan.pdf (retrieved 21 January 2018). 
At the very least, Moscow's attitude regarding the status of the 14 newly independent states formed out of the collapse of the Soviet Union is that they are intimately linked to Russia, are to a greater or lesser extent historically part of Russia and form Russia’s security perimeter. From Moscow's perspective, they must therefore be recognised as within Russia's sphere of strategic interest and must not be permitted to act in ways that are deemed to be contrary to Russia's vital interests. Putin sees his country as facing a weak Europe, ineffective and leaderless, overwhelmed by a huge refugee problem, and with the United Kingdom's exit from the European Union (EU) as heralding the unravelling of European unity.

The final issue I wish to raise about Russia pertains to some of the disturbing geopolitical propositions that have been gaining traction in Moscow. Most prominently, there is the idea of 'Eurasia', which Putin is proselytising. Starting with the Slavophiles in the 19th century, many Russian intellectuals saw Europeanness as the main problem of defining Russia's nationhood. Since 1991, the terms 'Eurasia' and 'Eurasianism' have once again come to prominence on the post-Soviet political scene. As Marlene Laruelle observes, this terminology suggests that Russia occupies a dual or median position between Europe and Asia. ${ }^{11}$ It rejects the view that Russia is on the periphery of Europe; on the contrary, it interprets the country's geographic location as grounds for choosing a messianic 'third way'. This doctrine is attractive to many Russian politicians because it helps them formulate an explanation for the collapse of the Soviet Union and to restore a sense of Russia's continuity from its troubled past 'by recasting it in spatial rather than temporal terms'. ${ }^{12}$ In particular, the Eurasianists want to put an end to the post-Soviet elites' mimicry of the West and to condemn the failure of communism as the end of a European idea.

Neo-Eurasianism has found its place within the new patriotic doctrine of Putin's Russia, and the main proponent of the new geopolitical rightwing is Alexander Dugin, who opposes US globalisation and describes his geopolitical doctrines as sacred geography (sacral'naia geografiia). In his book, Last War of the World Island, Dugin argues for Russia's return to its geopolitical function as the continental Heartland-a concept

11 Marlene Laruelle, Russian Eurasianism: An Ideology of Empire, Woodrow Wilson Center Press, Washington, DC, 2008, p. 1.

12 Ibid. 
he deliberately copies from Halford Mackinder. ${ }^{13}$ He identifies Russia as a 'Civilisation of Land' and believes that Russia's occupation of the Heartland is the land-based (telluric) core of the entire Eurasian continent in what he describes as its unchanging geopolitical spatial sense (raumsinn). Dugin proclaims that Russia 'is doomed to conflict' with the Civilisation of the Sea (thalassic) embodied today in the United States and the unipolar America-centric world order. ${ }^{14}$ It should be noted that his books are assigned as textbooks at the General Staff Academy and other military universities in Russia.

How influential is Dugin? Laruelle believes he can be considered to represent the general evolution of the Russian nationalist milieu over the past two decades; she says he is one of the few thinkers to engage in a profound renewal of Russian nationalist doctrines. ${ }^{15}$ Mackinder's concept of the Heartland was quoted approvingly in 2009 by Nikolai Patrushev, the secretary of Russia's Security Council and former head of the Federal Security Service (FSB), which was the first time that this vocabulary had emerged in public at such a senior level. ${ }^{16}$ In 2013, Putin himself endorsed the Eurasian idea when he said that 'Eurasian integration is a chance for the entire post-Soviet space to become an independent centre for global development, rather than remaining on the outskirts of Europe and Asia. ${ }^{17}$ In May 2015, the treaty creating Putin's 'Eurasian Union' was signed in the Kazakh capital, Astana, with Kazakhstan and Belarus as members. ${ }^{18}$ Thus, Eurasia has become the officially sanctioned national idea of Russia, articulated by its head of state. It matches Dugin's prognostication that Russia is different and unique and that, as it is under attack from the West, it must seek geopolitical strength in the Heartland.

13 Alexander Dugin, Last War of the World Island: The Geopolitics of Contemporary Russia, Arktos, London, 2015, p. 135.

14 Ibid., p. 10.

15 Laruelle, Russian Eurasianism, pp. 141 and 143.

16 Charles Clover, Black Wind, White Snow: The Rise of Russia's New Nationalism, Yale University Press, New Haven, 2016, pp. 295-6.

17 Ibid., pp. 316-17.

18 Ibid., p. 330. 


\section{China's territorial ambitions}

Unlike Russia, China has not yet used direct military power to assert its territorial claims, but it is using such harsh coercion that-like Russiait is causing extreme apprehension in its neighbourhood. China continues to assert the right to use military force to recover Taiwan and has built up powerful military forces opposite Taiwan specifically designed to retake the island. The key unknown is when will Beijing lose patience with the waiting process and judge that Washington lacks the fortitude to go to war with China over Taiwan. The Pentagon's latest report to Congress makes it clear that China continues to focus on preparing for potential conflict in the Taiwan Strait and that the People's Liberation Army (PLA) is developing and deploying military capabilities intended to coerce Taiwan or to attempt an invasion, if necessary. ${ }^{19}$ However, the Pentagon report also observes that large-scale amphibious invasion is one of the most complicated and difficult military operations and that an attempt to invade Taiwan would strain China's armed forces and 'invite international intervention'. ${ }^{20}$

China's territorial ambitions in the South and East China seas have been pursued with great belligerence in recent years, and they are the most likely source of miscalculation leading to direct military conflict with the United States and its allies. China is heavily dependent upon unhindered maritime traffic through the South China Sea, through which one-third of the world's trade and 80 per cent of China's oil imports pass. What President Xi Jinping terms China's 'Malacca dilemma' has led him to propose a geopolitical alternative called One Belt, One Road (OBOR), which would see more secure Chinese transportation routes across the Indian Ocean-as well as through Central Asia-and avoid the strategic bottlenecks of South-East Asia. OBOR aims to replicate the domestic success of Chinese state capitalism over the last 25 years on a Eurasian continental scale. ${ }^{21}$ But it will take decades to implement and will face resistance to the heavy-handed way in which Beijing typically operates in foreign countries.

19 Office of the Secretary of Defense, Annual Report to Congress: Military and Security Developments Involving the People's Republic of China 2016, Washington, DC, April 2016, p. 87.

20 Ibid., p. 89.

21 Christian Dargnat, 'China’s shifting geo-economic strategy', Survival 58, no. 3, 2016, p. 71. 
Like Russia, China is a continental power with little historical experience of being a maritime power. Robert Ross has argued that China's maritime power will be limited by the constraints experienced by all land powers, including the geopolitical sources of the repeated failure of land powers to secure maritime power. ${ }^{22}$ His main thesis is that land powers confront internal threats that impose severe resource constraints in developing maritime power, whereas the geographic circumstances of maritime powers offer enduring border security and ready access to the sea. It is a telling point, in this regard, that China spends as much on internal security as it does on its defence build-up. In the Cold War, another land power, the Soviet Union, practised the same sort of access denial capability to reduce the challenge of US carrier-based aircraft to its territorial security that China is now implementing. But China has a surface fleet without organic airpower and nuclear-powered submarines that remain relatively noisy. Its land-based air capabilities are insufficient to enable China to project decisive power in even the relatively near waters of maritime East Asia. China is not yet capable of successfully challenging US dominance of regional sea lanes or the security of the United States' allies in East Asia. ${ }^{23}$ As the Economist observes, China needs Western markets; its neighbours are unwilling to accept its regional writ, and for many more years the United States will be strong enough militarily and diplomatically to block it. ${ }^{24}$

But that is by no means all the story about China's territorial ambitions. It has played its cards craftily in the South China Sea by undertaking land reclamation, building infrastructure and introducing habitation on an incremental basis while at the same time avoiding the direct use of military force. It has persistently lied about not militarising these islands, rocks and reefs. China does all this while asserting that it has 'indisputable sovereignty over the islands in the South China Sea and adjacent waters and enjoys sovereign rights and jurisdiction over the relevant waters as well as the seabed and subsoil thereof'. ${ }^{25}$ On 12 July 2016, however, the UN Permanent Court of Arbitration rebuffed Beijing in a clear-cut ruling that concluded there was no legal basis for China's claims regarding resources falling within the nine-dashed line and, moreover, that none

22 Robert S. Ross, 'China’s naval nationalism', International Security 34, no. 2, 2009, p. 47.

23 Paul Dibb and John Lee, 'Why China will not become the dominant power in Asia', Security

Challenges 10, no. 3, 2014, p. 18.

24 'What China wants', Economist 412, no. 8901, 2014, p. 9.

25 Note Verbale to the United Nations Secretary-General, May 2009, quoted in Asia-Pacific Maritime Security Strategy, Department of Defense, Washington, DC, July 2015, p. 8. 
of the Chinese-occupied features in the Spratly chain could be classified as islands. ${ }^{26}$ This delivered a stinging rebuke to China. As might be expected, Beijing responded by rejecting the jurisdiction of the court as being 'null and void, with no binding force'. ${ }^{27}$ Vice-Foreign Minister Liu Zhenmin was reported as proclaiming that China reserved the right to declare an air defence identification zone (ADIZ) over the entire South China Sea, and President Xi Jinping told visiting EU leaders Donald Tusk and Jean-Claude Juncker that China's interest in the South China Sea would 'in no circumstances be affected' by the ruling of the Permanent Court of Arbitration. He stated that ' $[t]$ he South China Sea Islands have been China's territory since ancient times' and that '[w]e refuse to accept any claims or activities based on the arbitral ruling'. ${ }^{28} \mathrm{He}$ said China was committed to settling through direct talks the disputes with fellow claimants Vietnam, Malaysia and Brunei, as well as the Philippines. In fact, Beijing has strung along the Association of Southeast Asian Nations (ASEAN) claimants for the last 14 years while supposedly negotiating a code of conduct in the South China Sea. So, while China claims it remains committed to resolving the relevant disputes through negotiation and consultation with the countries directly concerned 'on the basis of respecting historical facts', there can be no expectation of any resolution of this potentially dangerous territorial stand-off.

Tensions now seem likely to rise, but it remains to be seen what Beijing's next steps will be. Australia's former Ambassador to China believes that in the end all that is left is diplomacy and that negotiation between claimant states is the only path towards some sort of resolution. ${ }^{29}$ At the same time, he recognises that China's leaders are now under enormous popular pressure to be seen to be standing up for China's territorial sovereignty. Any sign of weakness in the face of what will be seen widely in China as a national humiliation will provide a legitimate opening to attack $\mathrm{Xi}$ Jinping. Beijing could respond belligerently to the arbitral finding by more aggressively building and militarising various structures, moving more oil exploration and drilling platforms into the area, and increasing

26 Jane Perlez, 'Tribunal rejects Beijing's claims within South China Sea', New York Times, 12 July 2016, www.nytimes.com/2016/07/13/world/asia/south-china-sea-hague-ruling-philippines. html (retrieved 21 January 2018).

27 Jingye Cheng, 'Arbitration on South China Sea dispute fatally flawed', Australian, 14 July 2016, p. 12.

28 An Baijie and Fu Jing, 'Ruling "null and void", with no binding force', China Daily USA, 13 July 2016, usa.chinadaily.com.cn/epaper/2016-07/13/content_26073364.htm (retrieved 26 August 2017).

29 Geoff Raby, 'It's impossible for Xi Jinping to give in to The Hague', Australian Financial Review, 14 July 2016, p. 47. 
its harassment of fishing boats from other claimant states. ${ }^{30}$ But the fact is that there is now a much greater chance of miscalculation or an accidental military confrontation. There are those who believe that China and the United States are now so intertwined economically that military conflict is out of the question and that now is the time for restraint. That might be true, but in my view the time has come when the United States and its allies-including Australia-will have to demonstrate to China that it cannot make unilateral territorial land grabs. That will involve us undertaking deliberate freedom of navigation operations in the South China Sea and conducting regular intrusive aerial surveillance.

There is one final Chinese territorial proposal that I need to address. In various regional forums, including my involvement on behalf of the Department of Foreign Affairs and Trade (DFAT) with the ASEAN Regional Forum, China is pushing the idea of the need for a comprehensive review of the regional security architecture. This includes examining the rationale for and ingredients of a new security order for the region at a time of major rebalancing between rising and established powers. ${ }^{31}$ The idea here is to revisit the existing security order critically, including the system of bilateral alliances. This is, of course, a ploy by China-supported by Russia - to get rid of the US alliance system as relics of the Cold War. It is a dangerous proposition because the collapse of the US alliance system would inevitably lead to a nuclear-armed Japan, South Korea and Taiwan, which would be against China's national interests. Another concern is the argument of those who demand that the United States make strategic space for a rising China. ${ }^{32}$

It is not clear what is being proposed here: is it handing over a democratic Taiwan, and is the idea also to concede ownership of the South China Sea to Beijing? The central geopolitical question here for Australia is whether Beijing is aiming for a sphere of influence over South-East Asia as a collection of small countries effectively having subordinate status. ${ }^{33}$ If that occurred, it would face Australia with a potentially hostile power based in its neighbourhood.

30 Ibid.

31 I represented Australia at the ninth meeting of the ASEAN Regional Forum Expert and Eminent Persons meeting in Helsinki, Finland, on 12-13 March 2015, where this issue was canvassed and rejected.

32 Hugh White, The China Choice, Black Inc., Melbourne, 2012.

33 Former People's Republic of China Foreign Minister Yang Jiechi stated at a July 2010 meeting with ASEAN, 'China is a big country and other countries are small countries, and that's just a fact'. John Pomfret, 'US takes a tougher tone with China', Washington Post, 30 July 2010, www.washingtonpost. com/wp-dyn/content/article/2010/07/29/AR2010072906416.html (retrieved 20 January 2018). 


\section{Australia's new strategic geography}

The United States' 'pivot' to Asia, mainly to counter China's rise in the region, has made Australia's geographical location much more important than it was in the Cold War. In the Cold War, Australia was distant from the main theatres of military confrontation in Europe and North-East Asia. Its main strategic relevance to the United States was as 'a suitable piece of real estate', as Des Ball described it, for the location in central Australia of some of the United States' most potent intelligence collection facilities at Pine Gap and Nurrungar. Australia also conducted covert submarine intelligence operations against the Soviet Navy, as well as tracking Soviet nuclear submarines with P3 Orion reconnaissance aircraft. Now, however, Australia is critically located between the Indian and Pacific Oceans and relatively near South-East Asia and the South China Sea flashpoint. Former Defence Minister Kim Beazley has pointed out the relevance of Australia's secure location for the United States in the southern hemisphere. Unlike US military forces stationed in Japan, South Korea and Guam, the south of Australia is not within range of China's anti-access/area denial conventional weapons. Australia can offer the United States access to naval harbours and military airfields in the west and north of Australia so that it can project power into the eastern Indian Ocean and South-East Asian waters. The United States is increasing its footprint in Australia as part of its 'rebalance' to Asia. Australia's northern military facilities already host on-rotation elements of a US Marine AirGround Task Force of up to 2,500 personnel as well as the deployment of B-52 bombers to Darwin.

Australia should stand ready to provide more assistance to the US military given the growing strategic importance of and uncertain outlook in the region to our north. As already mentioned, South-East Asia is of critical importance to Australia's security: it is a shield to Australia's sparsely populated and resource-rich northern approaches. Australia would be concerned about the threat of a foreign military power seeking influence in South-East Asia in ways that could challenge the security of our maritime approaches. Such a military presence or lodgement has long been a concern in Australian defence planning. 
The 2016 Defence White Paper reflects serious concern in Canberra about China's worrying military build-up and its flaunting of the established rules-based international order. In fact, the White Paper mentions Australia's strong support for the 'rules-based global order' 54 times in a scarcely concealed allusion to the People's Republic of China. It stresses that 'the rules-based order is under increasing pressure and has shown signs of fragility'. ${ }^{34}$ However, although Russia and North Korea are cited specifically as being guilty of refusal to act in ways consistent with international law and standards of behaviour, China is mentioned only obliquely along the lines that 'newly powerful countries want greater influence', but they also 'have a responsibility to act in a way that constructively contributes to global stability, security and prosperity'. ${ }^{35}$ The White Paper does not contain more direct criticism of China's repeated flaunting of international order and stability in the region. There is, however, a specific mention of China's activities in the South China Sea, where it is stated that 'Australia is particularly concerned by the unprecedented pace and scale of China's land reclamation activities'. ${ }^{36}$ Predictably, this provoked an outraged response from Beijing.

The White Paper observes that Australia can expect greater uncertainty in its strategic environment over the next two decades as a consequence inter alia of 'changes in the distribution of power' in the Indo-Pacific and 'the modernisation of regional military capabilities'. ${ }^{37}$ It states that the Australian Defence Force (ADF) must be better prepared to meet a broader range of security challenges in the coming years. ${ }^{38}$ Maintaining Australia's technological edge and capability superiority over potential adversaries has been an essential element of our strategic planning now for more than 30 years, but the White Paper observes that Australia's capability superiority in future will be challenged by military modernisation in the region. ${ }^{39}$ Classified concerns about China's military build-up and its continuing provocations in the South China Sea caused the Defence

34 Australian Government, 2016 Defence White Paper, Department of Defence, Commonwealth of Australia, Canberra, 2016, p. 45, www.defence.gov.au/WhitePaper/Docs/2016-Defence-WhitePaper.pdf (retrieved 16 January 2018).

35 Ibid.

36 Ibid., p. 58.

37 Ibid., p. 32.

38 Ibid., p. 34.

39 Ibid., p. 16. 
White Paper to elevate the security of South-East Asia to Australia's most important strategic interest after the defence of Australia and our northern approaches. The White Paper states:

The geography of the archipelago to Australia's immediate north will always have particular significance to our security. Any conventional military threat to Australia is likely to approach through the archipelago. ${ }^{40}$

It goes on to say: 'Proximity and economic interests mean that instability in South-East Asia, whether internal to countries or between countries, has the potential to affect Australia's security', ${ }^{41}$ and it observes that '[a]s our near neighbour, Australia's relationship with Indonesia is vital'. ${ }^{42}$

In addition to its heavy focus on maritime South-East Asia, the Defence White Paper revisits the importance of Australia's military facilities in the north and west of the continent-some of which have been ignored and run down over recent years. The White Paper states that while there is no more than a remote chance of a military attack on Australian territory by another country, Australians rightly expect that our armed forces be capable of the self-reliant defence of our territory from attack or coercion by another country. ${ }^{43}$ Therefore, the government has committed itself to providing defence with 'the capability it needs to be able to decisively respond to military threats to Australia, including incursions into our air, sea and northern approaches. ${ }^{44}$ Investment in Australia's northern military bases will now be increased substantially so that they can support new capabilities that will be used to defeat any attack on our territory. Investment in Australia's national defence infrastructure will include the army, navy and air force bases in northern Australia, including in Townsville and Darwin as well as the air force bases in Tindal, Curtin, Scherger and Learmonth. ${ }^{45}$ This will enhance infrastructure in northern Australia to support the ADF's strike and air combat capabilities, including Joint Strike Fighters, Wedgetail airborne early warning and control aircraft, and air-to-air refuellers. ${ }^{46}$ The Jindalee over-the-horizon radar (OTHR) radar network and other surveillance, space and air defence-related facilities in

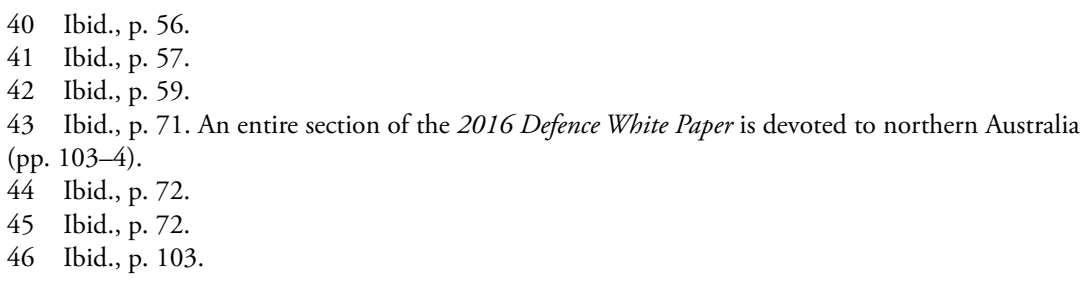


northern Australia will be upgraded over the next decade. ${ }^{47}$ There is also a commitment to upgrade the infrastructure on Cocos (Keeling) Islands in the eastern Indian Ocean to support flights by the new P-8A Poseidon maritime surveillance aircraft. ${ }^{48}$ The White Paper states that Australia's maritime forces will become more potent through the acquisition of more capable submarines, ships and aircraft so that these forces will help to protect Australia's maritime borders, secure our immediate northern approaches and proximate sea lines of communication, and enable Australia to project force in the maritime environment-especially our trade routes through the South China Sea through which nearly twothirds of our exports pass. ${ }^{49}$

All this amounts to a significant geographical refocusing of the ADF, which has been preoccupied over the last 15 years with almost continuous deployments to the Middle East and Afghanistan. The current geographical refocus on maritime South-East Asia and the complementary upgrading of military bases in the north of Australia, after years of lack of attention, marks a triumphant return of geography to Australia's defence planning. 


\section{9 \\ Strategic studies in practice: An Australian perspective}

\section{Hugh White}

Ours is a practical discipline. Our aim is, or should be, always to bring the virtues and strengths of scholarship to bear on the real and often urgent practical choices that nations-and especially their governments-face about strategic policy: about how we develop and use armed force to achieve national policy objectives. So it seems appropriate to mark our centre's 50 th anniversary by reflecting on the practical strategic policy choices that Australia faces today. That is what the Strategic \& Defence Studies Centre (SDSC) has always done best and how it has made its most important contributions over the decades. I will try to do this here by reflecting a little on history, not just because this seems fitting for an anniversary but also because it is often the best way to address these practical questions in a scholarly way. Our focus should always be on the future because policy is always about the future, but the only way we can think seriously and systematically about the future is through a sophisticated understanding of the past.

So this chapter will explore something of Australia's strategic past in order to illuminate the choices we face today about our strategic future. I shall try to sketch some long-running strategic questions that seem to be distinctively Australian because they spring from our specific-and in some ways unique-strategic circumstances. My hope is that reflecting 
on how Australia has approached these questions in the past will help us to better understand the choices we face today about our strategic policy and posture in future.

Bob O'Neill last night at dinner mentioned the Seven Years War, reminding us that this was truly the first world war, fought not just in Europe but also in North America and Asia. It also marks in a very real sense the start of Australia's strategic history because it created the strategic preconditions for British settlement of this continent. Britain defeated the French in the waters around India during the Seven Years War and thus became the primary maritime power in what we might now call the Indo-Pacific. Establishing an outpost at Sydney Cove became possible only once Britain had established this primacy, and the outpost in turn, once established, helped to make its primacy more secure.

More broadly, the global maritime preponderance that Britain won in the Seven Years War, and the economic revolution that it was both sustained by and helped to sustain, gave Britain the power to seize, hold, colonise, develop and populate our continent. Without the Seven Years War, this nation would not exist on this continent, and most of us would not be here.

This reminds us that strategic questions - questions of the role of force in international affairs-have been part of Australia's story from the very beginning. There never was a time of pre-strategic innocence. We were, so to speak, born in strategic sin, a product of the extraordinarily dynamic power politics of the later 18th century as Europe's strategic order was transformed by radical changes in the distribution of wealth and power and an accompanying revolution in ideas. We can see something of the intensity and global reach of the resulting rivalry in La Perouse's remarkable appearance in Botany Bay just a couple of days after Arthur Phillip arrived with the First Fleet. Only four years later, Britain was plunged into the epic series of European wars that completed the destruction of the old European order and ushered in a new one. The establishment of British settlement in Australia thus took place against the background of a world in conflict, the biggest and most costly war in history up to that time, which profoundly touched every aspect of British national life. Although it does not feature much in our national narrative of those first decades of settlement, the Revolutionary and Napoleonic wars must have loomed very large indeed for the colonists in Australia in that first quarter-century of settlement. 
The outcome of those wars had a profound effect on the strategic setting of Australia's first century and has perhaps shaped the way Australians have seen their security ever since. By 1815, Britain's maritime primacy in Asia and globally was consolidated beyond serious challenge, so that British settlements in Australia enjoyed the luxury of being protected by a power that exercised complete command of the world's oceans, including those that surrounded the continent and connected it with Britain and the rest of the world. Britain's position in turn was protected by the Concert of Europe, which constrained strategic rivalry with its powerful continental neighbours and thus ensured that Britain's strength globally, and in our region, was not be sapped by the need to meet major threats to its security in Europe.

It is therefore only natural that for about a century after they were established, the British settlements faced no specifically Australian strategic questions. We were embedded in a global empire with no serious rivals and with the capacity to deploy and sustain such overwhelming maritime force against any threat to us such that the risk of serious strategic challenge was negligible. There was therefore little reason for colonists to think about strategic questions. To the extent that they did, they thought about the empire's security rather than Australia's. I hope I do not have to labour the contemporary parallels.

One might say, then, that Australia was born in strategic sin but enjoyed a blissfully innocent strategic adolescence. That happy time came to a surprisingly abrupt end in the last quarter of the 19th century. By about 1880, the economic preponderance that Britain had won with the Industrial Revolution and with which it had sustained its global maritime power was being challenged and even eclipsed by new rising economic powers-most obviously America and Germany but also France, Russia and-a little later-Japan. Moreover, some of these powers were starting to intrude into our neighbourhood. Australian colonial governments were plainly aware of the shifting distribution of power and started to worry about what these local intrusions could mean for their security. They sought a firm imperial response, for example to Germany's occupation of northern New Guinea, and they did not get it. As the distribution of power shifted and pressure on the 19th-century European order grew, Britain had to balance much more carefully the interests of its empire against the overriding imperative to manage growing strategic risks in Europe. 
This presented Australian political leaders with a new situation-and they understood it swiftly. They could no longer assume that Britain had the power and the will to keep Asia safe for Australia. They could no longer assume that London's strategic interests, objectives and priorities were identical with Australia's. They had to start thinking for themselves and acting to pursue distinctly Australian policy responses to specifically Australian strategic imperatives. They soon came to understand the key features of Australia's strategic situation, which remain with us today. On the one hand, Australia is almost uniquely isolated from the main centres of power globally, and from the great and powerful friends on which we rely. On the other, we are deeply integrated into the global strategic system: we believe our security depends on the balance between the major powers in the key theatres of strategic rivalry because we believe that the active support of a global power ally is essential to our security.

This creates the perennial dilemma that has framed Australian strategic policy ever since the 1880s. We must depend on our allies because we do not believe we can defend ourselves independently, yet we cannot depend on our allies because we are so remote from them, and our most pressing strategic threats will always be different from theirs. For all the talk of shared values and culture, alliances are based on shared interest, and interests are deeply embedded in geography. This deep dilemma is inherent in our geographic circumstances, so it cannot be resolved or dissolved. It must instead be managed, as that first generation of Australian strategic policymakers very plainly understood. Managing it means asking and answering the great question at the heart of Australia's strategic policy: how far do we depend on our allies, and how far do we try to fend for ourselves? How clear sighted and courageous that generation, led by Alfred Deakin, was in facing this daunting challenge. Of course they were people-men-of the Victorian era, to whom courage and enterprise and rapid change came naturally. To see that spirit at work we need look no further than Deakin's remarkable contribution to the Colonial Conference in London in 1887, where he set out with startling clarity the strategic challenges that were to face the British Empire and its constituents over the coming decade. ${ }^{1}$

The key result of their work was, of course, Federation, which more than anything else was a response to the new strategic challenges that emerged in the late 19th century. On that foundation they built a quite

1 See, for example, J.A. La Nauze, Alfred Deakin: A Biography, Melbourne University Press, Melbourne, 1965, pp. 95ff. 
sophisticated policy that balanced the opposing imperatives of alliance and self-reliance, between depending on others and fending for ourselves. Perhaps unavoidably, the principal weight lay with supporting our allies, in part because over coming decades those allies faced tests far bigger and more serious than anything Deakin and his colleagues could have imagined.

It is sobering and poignant to reflect on how Alfred Deakin and his contemporaries would have felt at the time of Federation had they been given a glimpse of the strategic challenges that lay ahead. The trends they had so presciently identified in the 1880 s did indeed have far-reaching and disastrous consequences. In two world wars, British power globally and in Asia faced immense challenges and finally collapsed. US power rose to take its place, but it too faced major challenges globally and in Asia. Australia made huge sacrifices to help respond to these challenges in World War I, World War II, Korea, Malaya and Vietnam. The alliance with Britain did not survive, and its alliance with the United States suffered immense stress. By the mid-1960s, reliance on great and powerful friends seemed less and less credible as the long-term foundation of Australia's security. It was time for a rethink.

There are good reasons why Australia's first centre for the academic study of strategic and defence questions was founded in 1966. In part the timing reflected a wider trend: under the stresses of the Cold War, academic study of strategic questions had taken off in the United States, Britain and Europe during the 1950s, and a number of Australians-most notably our own Hedley Bull and Coral Bell—had played significant parts in that. It was natural enough that Australia would eventually follow this trend. But more important than this were the local circumstances. In 1966, Australia faced a remarkable, complex and momentous set of changes in our strategic circumstances comparable in scale and significance to the transformation of the last decades of the previous century.

By 1966, these changes were already undermining the grand strategy of Forward Defence, which had evolved to deal with the new and unfamiliar challenges of the Cold War in post-World War II post-colonial Asia. In the late 1950s and early 1960s, it became increasingly clear that Australia could not rely on our major allies to help us deal with the challenges posed by the aggressive policies of Sukarno's Indonesia. Geography ensured that they affected our strategic interests differently and more directly than our allies'. By 1966 Sukarno had fallen, but it was not yet clear 
just how different Suharto's Indonesia was going to be. And in order to buttress Washington's support against Indonesia as well as respond to the wider threats that seemed to be posed by Maoist China, Australia had supported and indeed encouraged a deeper US commitment to Vietnam. Within a few years, the whole fabric of Forward Defence had fallen apart. Escalation and failure in Vietnam led to Nixon's declaration in Guam in 1969 of substantial US strategic retrenchment in Asia. The year before, in 1968, Britain's long and painful post-imperial decline reached the point that it could no longer sustain a strategic presence in Asia. Wilson's 'East of Suez' announcement that year marked the end of any British commitment to help defend Australia or its interests in Asia. So, in SDSC's first three years, Australia's confidence in both of the great alliances on which its strategic policy was based had been undermined, and indeed overturned.

Today, we do not really recognise how shocking and disconcerting 'East of Suez' and 'Guam' were for that generation of policy-makers and analysts, and how fundamental they were to the defence policy revolution of the 1970s, and hence to our defence policies now. That is in part because they were accompanied by other changes that, while not at that time as plain as the eclipse of our alliances, were in the long run more important. Alongside the bad news about our alliances there was a lot of good news about our region. Over the next few years, Suharto consolidated his New Order and transformed Indonesia into a bastion of regional order. SouthEast Asia more broadly changed quite quickly from a major global trouble spot to become a model of progress and cooperation. The instability of the first post-colonial decades eased, and we saw real political, economic and social development in many countries. The Association of Southeast Asian Nations (ASEAN) emerged as an effective foundation of regional stability. Most important of all, Nixon's opening to China transformed the wider Asian regional order by eliminating - for a time-the strategic rivalry between these, the two strongest powers in the Asia-Pacific region. After 1972, the United States' strategic position was uncontested by any major Asian power. Paradoxically, failure in Vietnam, far from destroying the United States' position in Asia, immensely strengthened it. This marked the effective end of the Cold War in Asia and the emergence of the US-led regional order that kept Asia peaceful and prosperous for 40 years, and kept Australia safe. Until the late 1980s, the United States still faced a bitter global rival in the Soviet Union, of course, but the later stages of the Cold War impinged surprisingly little on Australia's sense of its security after 1972 . 
All these tumultuous changes in the first decade of SDSC's life-both the bad news and the good news - drove a radical rethink of Australia's strategic and defence policy, causing it to involve new approaches to those old questions about how much we could depend on our allies and how far we should be able to fend for ourselves. Much of this was driven by some notable political leaders, including Gorton, Fraser, Whitlam and Barnard; by a remarkable group of public servants led by the redoubtable Arthur Tange; and including such figures such as Bob Hamilton and Bill Pritchett. But it did not all happen behind closed doors. From the mid1960s to the mid-1970s, there was a remarkable efflorescence of public debate about how Australia should respond to the shifts in our strategic environment that everyone acknowledged were taking place and so plainly had big implications for defence and foreign policy. SDSC itself was at the very heart of this debate, which did a great deal to help build its position in the university, in Canberra and nationally.

Indeed, the origins of SDSC and start of serious public debate about Australia's post-Forward Defence grand strategy can both be traced to the same event: the publication in 1965 of Tom Millar's ground-breaking monograph on Australian defence policy, Australia's Defence. ${ }^{2}$ Its theme was announced on the dustcover flap in bold type: 'Can Australia Defend Itself?' This simple, weighty question became the focus of the national defence debate over the next decade and beyond, and has in some ways remained the core focus of SDSC's best work ever since.

The debate back then, however, had a distinctive tone. It was energised by the trauma of the Vietnam War, which made defence and strategic policy the most important and divisive issue in national politics throughout the later 1960s and early 1970s. It engaged strong arguments and deep emotions on both sides of politics, on both sides of the argument, and divided Australian society like no issue since. Moreover, it became a proxy for deeper questions about Australia's identity, its relations with Britain and the United States, and its future in post-colonial Asia. These questions were debated with a vigour and brutal clarity that surprises us today.

Few people now recall that Donald Horne's Lucky Country—perhaps the most influential book ever written about the Australian identity-was an exploration of these questions. Writing in 1964, Horne conjured the idea that Australia is destined to be severed from our Anglo-Saxon roots and

2 T.B. Millar, Australia's Defence, Melbourne University Press, Melbourne, 1965. 
instead 'peopled from all over Asia.' No one then believed that Australia would not have to make some momentous choices as it adapted to life in a fast-changing Asia. To Horne and his contemporaries, today's mantra of 'we don't have to choose' would have seemed simply absurd.

Another factor that affected the tone and substance of the strategic debate at that time was the personal experiences of those who took part in it. Bob O'Neill again invoked that experience last night when he recollected listening around the family radio on 8 December 1941 to the news of Japan's assault and the coming of the Pacific War. Likewise, Coral Bell's brief memoir opens with her recollection of where she was and how she felt when she heard the news of the nuclear attack on Hiroshima that brought the war to an end. ${ }^{4}$ This generation —all of them-had direct personal experience of major-power wars in our region, of the stressing and collapse of regional order, and of direct threats to Australia by major powers. Many of them had of course served themselves in these wars. Perhaps most importantly, their direct experience of alliance failure was central to their understanding of strategic risks and strategic policy imperatives and shaped their ideas and debates in ways that we today seem too easily to overlook.

The result of this long, deep, serious debate against the background of the momentous changes taking place in our region and beyond was a very marked shift in the balance of Australia's defence policy from alliance dependence to self-reliance. It took 20 years in all, with many important steps along the way, but as it happens this year (2016) marks notable anniversaries of the two most important of them. In 1976, 40 years ago, the Fraser Government released the first of Australia's modern Defence White Papers, Australia's Defence, which set out with great clarity the central idea that the principle purpose for which Australia's armed forces should be designed and built was the self-reliant defence of our own continent rather than the support of allied operations beyond it. And in 1986, 30 years ago, the Dibb Review set out in great detail and sophistication how that should be done and what forces were needed to do it.

The ideas developed in these documents remain in many ways the conceptual foundation of Australia defence policy today, although they have often been rather poorly understood by many people both within

3 Donald Horne, The Lucky Country, Penguin, Melbourne, 1964.

4 Coral Bell, 'A Preoccupation with Armageddon', unpublished memoir, Canberra, 2012. 
the defence establishment and outside it. This is not the place to explore and correct the misunderstandings. Suffice it to say here that the 'Defence of Australia' policy, or DoA as it became known, both expanded and contracted the key purposes our forces were designed to fulfil. They were required to defend the continent independently, but only against the modest forces of a local regional power-Indonesia, in reality. They were not designed to fight the forces of a major Asian power either in the direct defence of Australia or to support allies in the wider region. That posture was credible only because we were confident that the United States would remain the uncontested primary power in Asia, thus precluding the possibility either of a major-power threat to Australia or of a majorpower challenge to the United States' position serious enough to require Australian military support. It was the uncontested primacy of the United States in Asia that made Australia's DoA policy possible.

This helps explain why, somewhat paradoxically, the era of self-reliance has become a golden age for Australia's alliance with the United States. In the 1980s, the fierce contentions of the Vietnam era had fizzled and died. Fervent support for the alliance became universal across the political spectrum. And why not? With Asia stable and peaceful under uncontested US leadership, the strategic interests of Australia and the United States were clearly aligned and very cheaply achieved. Australia demanded nothing of the United States, and it demanded very little indeed of Australia. As the memory of the tough choices and hard debates of the 1960s faded, it was easy for the US alliance to become somewhat romanticised. It was even easier when the Cold War ended and the United States emerged as the global hyperpower of the unipolar era. Australia envisaged a flattering place for itself as the very closest ally of the world's preponderant military, economic, political and cultural power. Not surprisingly, the uncertainties about the alliance that had driven the strategic debates of 50 years ago dropped away. It became easier and easier to assume that the United States would always, far ahead as we can see, have the power and the will to remain the dominant power in Asia and the sure protector of Australia's security. Not surprisingly, our strategic policy swung back to depending on our allies rather than fending for ourselves.

'Self-reliance' has become an empty term, interoperability with US forces has become, it seems, the primary factor in capability planning, and the focus has swung sharply from conducting independent operations to contributing contingents to US-led coalitions. Australia today is more comfortable relying on our allies for our security than we have been at 
any time since 1880 . Indeed, in the post-Cold War era it has seemed as if Australia has returned to the happy situation that we enjoyed in our strategically innocent national adolescence before 1880 as a close strategic partner of the globally dominant Anglo-Saxon hyperpower that is the uncontested leading strategic power in Asia. Why then worry much about our own defence? Why fend for ourselves when we have such an ally to rely on?

Which brings us to today and what are surely the most important questions confronting Australian strategic policy-makers and analysts in the late 2010s. Can this last? Will the swing from fending for ourselves back to relying on our allies work for us in the coming decades? The answer in turn depends on some further questions. How confident can we be that the United States will in future still play the role in Asia and in Australia's security that it has played over the past couple of decades? Above all, will it remain the uncontested primary power in Asia? And if not, what will happen to us, and what can we do about it? These are the biggest and most consequential questions confronted by Australian strategic policy since the great strategic upheavals at the time SDSC was founded 50 years ago. They arise today because of the immense shift in the distribution of wealth and power that has occurred as Asia's economies have grown, especially with the rise of China. That, in turn, has fundamentally transformed China's strategic objectives from those it adopted when Nixon met Mao in 1972. As a result, the United States no longer enjoys uncontested strategic primacy in Asia. Instead, we have seen, over about the past decade, a resurgence of strategic rivalry between the United States and China of a kind we have not seen since before 1972.

This is a fundamental shift in the position of our major ally in Asia and hence in our strategic circumstances. Australia's strategic policy has yet to address it coherently. There have been three Defence White Papers since this shift became plainly evident, in 2009, 2013 and 2016. All of them show deep ambivalence and uncertainty about how to respond. All acknowledge, to different degrees, the scale of the shift in wealth and power that is reshaping our strategic circumstances in Asia. All nonetheless conclude that no basic change in Australia's defence policy or broader strategic posture is necessary. All express confidence that the role of the United States in Asia and its support for Australia's security will not change within the next three decades, if ever. All of them attempt to conceal these complacent conclusions by overhyping what are in reality modest and 
very distant increases in naval capabilities. And, tellingly, each of these three documents has expressed more confidence about the future of US strategic leadership in Asia than its predecessor.

So we need to do better. That means addressing and debating more clearly and forcefully two big sets of questions. The first concerns the seriousness of the challenge to the US-led regional order on which our present policy so completely depends. That involves judgements about China's intentions, its power and its resolve. It also involves judgements about US intentions, power and resolve. Too many of us for too long have been content to assume that the United States will always remain decisively more powerful than China and more determined to preserve the US-led order in Asia than China is to replace it. It has therefore been too easy to assume that China can easily be persuaded to settle for little, if any, change in its relationship with the United States or increase in its regional leadership role. Those assumptions now require very careful scrutiny.

The second set of questions concerns the consequences for Australia if the challenge to the US-led order does indeed prove to be more serious than most of us assume. We need to explore the different kinds of new order that might emerge to replace it, the consequences of different future orders for Australia's security and prosperity, and the implications for the kind of order that we should be aiming to promote or avoid. The second concerns Australia's options for positioning ourselves as well as possible in whatever new order emerges-whether or not it be one that suits our interests. This has big implications both for our diplomacy and for the way we develop our armed forces. It will involve a rethink of our foreign and defence policies comparable in scale to the one that occurred in the decades after 1966.

I fear that future historians will find it remarkable, and regrettable, that so little attention has been paid to these questions both within government and in the wider strategic and foreign policy community over the past decade or more as the trends driving fundamental strategic change in Asia have become clearer and clearer. I think they will judge that we have failed to address the second set of questions because we have not yet got past the first. We have been in denial about the dynamics driving strategic change in Asia even as we celebrate the economic transformation that underpins it. We have collectively acquiesced to the assumption that Asia can be 
utterly changed economically yet remain quite unchanged strategically when any serious, historically aware study of strategy should warn us that this is most unlikely.

It seems likely that we have so readily acquiesced to the assumption because abandoning it implies such unsettlingly radical shifts in our foreign and defence policies. It suggests we must face up to choices we have no wish to make and that both sides of politics are equally unwilling to contemplate. In part that is because the practical, and particularly the fiscal, implications of some of those choices are so unwelcome. But more deeply it is because they go to questions of our national identity that we do not wish to expose and address. The questions Donald Horne raised back in 1964 remain difficult and sensitive ones for us today. For Horne and his generation, it was obvious that Australia did have choices to make between its history and its geography. Our generation welcomed John Howard's assurance that this was not so. He persuaded us that the United States' enduring preponderance meant that such choices need never be made. We have been reluctant to see the mounting evidence that he was probably wrong.

It has been easier for us to ignore this mounting evidence because our thinking about the alliance has been increasingly divorced from any historical context. This is not a failing in the areas of foreign and defence policy alone: Laura Tingle has written very tellingly about Australia's broader problem of political and policy amnesia. ${ }^{5}$ But it is perhaps particularly serious in our field of policy where hard data is so scarce and the lessons we can glean from history are correspondingly more important. Today, our thinking about the future of our alliance with the United States and America's role in Asia is hampered by the pervasive illusion that our allies and our alliance have always been just as strong and indubitable as so many of us imagine them to be today. We have forgotten Asia's history of power politics and strategic rivalry. We have forgotten Australia's history of alliance uncertainty and outright failure, including the fall of Singapore and the Guam Doctrine. We have forgotten too much of Australia's history, and of SDSC's own history, to see our future as clearly as we should if we are to sustain SDSC's proud record of service to our country. We need to do better.

5 Laura Tingle, Political Amnesia: How We Forgot to Govern, Quarterly Essay, no. 60, 2015. 


\title{
10 \\ Strategic studies in practice: A South-East Asian perspective
}

\author{
Peter Ho
}

I begin this chapter with two disclaimers. First, I am not an expert on strategic studies. Second, I do not think that a singular and monolithic South-East Asian perspective on strategic studies exists. In this regard, as far as I am aware, in South-East Asia, there is only one institute that is properly focused on the full range of strategic studies, and that is Singapore's S. Rajaratnam School of International Studies, or RSIS. ${ }^{1}$

\section{A personal history}

My encounters with strategic studies have been tangential. My first encounter occurred when I was in military service and a student at our command and staff course in Singapore. The course introduced me to thinkers like Mahan, Douhet, Liddell Hart and, of course, Clausewitz and Sun Tzu. We studied strategic concepts like nuclear deterrence, great

1 The S. Rajaratnam School of International Studies (RSIS) was established in January 2007 as an autonomous school within Singapore's Nanyang Technological University. Known as the Institute of Defence and Strategic Studies (IDSS) when it was established in July 1996, RSIS's mission is to be a leading research and graduate teaching institution in strategic and international affairs in the Asia-Pacific. 
power dynamics, liberation ideologies, Marxism-Leninism, Maoism, revolutionary warfare, counter-insurgency warfare, united front tactics, guerrilla warfare and so on.

For good reason, strategic studies were taught in tandem with military history. The orientation then, as now, was, not surprisingly, focused on the region, so the Malayan Campaign and the Malayan Emergency were dissected in some detail for the lessons that could be gleaned from these two upheavals. We were fortunate to have obtained the original manuscript of Masanobu Tsuji's detailed account of the planning and execution of the Japanese invasion of Malaya. Tsuji was a colonel in the Japanese Army and, as a member of General Yamashita's staff, planned the invasion.

Strategic studies and military history opened up an entirely new world for me. They provided insights into the past and, more importantly, an understanding of present issues - such as the Cold War, which was then still the central geopolitical fact of life.

But over time, I lost my currency in the vocabulary and the details, even though I have retained my understanding of the broad concepts. Having said that, in my time, Singapore luckily faced no conflict to test my understanding of these ideas and concepts. Luckily for me too, I was never put to the test. I think I would have been proven to be not very competent-certainly in the academic minutiae and probably as a military commander.

Some years after I completed the command and staff course at Singapore's Goh Keng Swee Command and Staff College, I led a review of the college's syllabi. The review, not surprisingly, asserted the importance of strategic studies and military history. So not only did strategic studies and military history remain at the core of the various programs run by the command and staff college, but a Department of Strategic Studies was also established.

Later on, in 1997, teaching of strategic studies and military history was outsourced to the new Institute of Defence and Strategic Studies (IDSS), which became a full school-RSIS-10 years later in 2007. This provided the Command and Staff College access to a team of experts whose primary business was strategic studies and military history, thus enhancing the quality of teaching in this important area. In return, it anchored strategic studies as a core capability of IDSS/RSIS. 


\section{Why strategic studies?}

At this point, it might be useful to ask a basic question: why is strategic studies important? I discovered its value later on in civilian life when I worked on plans and policy in the Ministry of Defence (Singapore), during my postings to the Ministry of Foreign Affairs, and when I was in charge of National Security and Intelligence Coordination (a department under the Prime Minister's Office).

It was in these positions that the concepts and constructs embedded in strategic studies really came alive for me. They provided an important foundation to help me to understand the world, discover the drivers of grand strategy, uncover the impulses of foreign policy and develop an instinct about how nations and governments respond to challenges and how they interact with one another. They helped me to connect strategy to operations and plans, and to frame decisions in their conceptual, intellectual, historical and ideological contexts.

But I also found out that, as a discipline, strategic studies are largely based on hindsight and historical insight, while my experience in planning and policy-making taught me that things never follow a predictable trajectory, especially in the medium to long term.

\section{Strategic surprise}

When I became a planner and a policy officer in the Ministry of Defence in the early 1980s, it would have been difficult for anyone to grasp the concept of transnational terrorism that today preoccupies defence and national security planners and policy-makers. We were still in the throes of the Cold War, although hindsight now tells us that the war was then already waning. In those days, the 'revolution in military affairs' (RMA) ${ }^{2}$ and cyber warfare were concepts that we could only dimly understand. Today, they have become part of mainstream thinking.

2 'According to Andrew Marshall, director of the Office of Net Assessments in the Office of the Secretary of Defense: "A revolution in military affairs (RMA) is a major change in the nature of warfare brought about by the innovative application of new technologies which, combined with dramatic changes in military doctrine and operational and organisational concepts, fundamentally alters the character and conduct of military operations."' Lothar Ibrugger, 'The revolution in military affairs', NATO Parliamentary Assembly special report, November 1998, www.iwar.org.uk/rma/ resources/nato/ar299stc-e.html (retrieved 21 January 2018). 
Indeed, one of the foremost challenges facing anyone in the business of planning or policy-making is the challenge of strategic surprise.

Most of us have heard of black swans, a term coined by Nassim Nicholas Taleb. ${ }^{3}$ They are rare, hard-to-predict events that have a large, gamechanging impact. Later on, in 2002, the then US Secretary of Defense, Donald Rumsfeld, introduced us to a close relative of the black swan, the unknown unknown. He said:

There are known knowns. These are things we know we know. We also know there are known unknowns. That is to say we know that there are some things we do not know. But there are also unknown unknowns, the ones we don't know we don't know. ${ }^{4}$

When he said this, a lot of people poked fun at him. But notions of known unknowns and unknown unknowns reflect a serious concept. If you are in the business of defence, or if you are in the military, you ought to understand what known unknowns are and what unknown unknowns are, because you are going to be surprised by both every now and then. And it helps to understand the difference between them.

In Singapore, we have had encounters with black swans and unknown unknowns in recent years: the Asian Financial Crisis of 1997-98; 9/11; the uncovering of the Jemaah Islamiyah terrorist network in December 2001; the global economic and financial crisis of 2008-09; the Arab Spring; the rise of ISIS or Daesh; Brexit; and so on.

The frequency of such strategic shocks seems to be increasing, and the amplitude of their impact is growing. Lenin explained why when he said, 'Everything is connected to everything else'. A few hundred years earlier, Leonardo da Vinci had said, 'Everything connects to everything else'. Both might even have been aware that the ancient Chinese philosopher Lao Tzu had made much the same observation some 1,500 years ago, that 'everything is connected and everything relates to each other'.

3 A black swan is a metaphor for an event that comes as a surprise, has a major impact and is often rationalised after the fact with the benefit of hindsight. The theory was developed by Nassim Nicholas Taleb and described in his eponymous bestseller The Black Swan: The Impact of the Highly Improbable, Random House, New York, 2010.

4 Donald Rumsfeld, the then US Secretary of Defense, responding to a question at a Department of Defense (DoD) news briefing on 12 February 2002 about the lack of evidence linking the Iraqi Government with the supply of weapons of mass destruction to terrorist groups. 'DoD news briefing-Secretary Rumsfeld and Gen. Myers', US Department of Defense, archive.defense.gov/ transcripts/transcript.aspx?transcriptid=2636 (retrieved 22 September 2016). 
Globalisation increases and intensifies these connections, as does the Internet. In such a connected world, what happens in one part of the world is going to affect other parts of the world-the so-called butterfly effect, which postulates that the flap of a butterfly's wings in Brazil can set off a tornado in Texas. ${ }^{5}$ The butterfly effect is the concept that small causes can have large effects. Events and actions in different parts interact with each other in complex, non-linear ways to produce effects that are difficult to determine ex ante. Instead, their behaviour is emergent. This is the defining characteristic of a complex system that today forms the basis of the new science of complexity. ${ }^{6}$

In December 2010, Mohamed Bouazizi, a street vendor in Tunis, set himself alight. He was upset by the lack of support from the Tunisian authorities. It was a terminal protest because he died from the selfimmolation. But that single act-a single event-triggered the Arab Spring. The consequences were dramatic. Governments collapsed in Tunisia, Egypt, Libya and Yemen. Governments changed in Kuwait, Bahrain and Oman. A civil war broke out in Syria, and it is still raging six years after Bouazizi killed himself. It can be argued that these events set the stage for the rise of the Islamic State or ISIS or Daesh.

The most imaginative novelist could not have written the script for the Arab Spring. The Danish philosopher Søren Kierkegaard once said, 'Life is understood backwards, but it must be lived forwards'. ${ }^{7}$ Encapsulated in this profound statement is the concept of retrospective coherence, otherwise known as hindsight. The current state of affairs always makes logical sense when you can look backwards in time. That is hindsight, and it helps us to understand why something happened. That is why strategic studies and military history are so useful.

5 Edward Norton Lorenz, an American mathematician, meteorologist and pioneer of chaos theory, introduced this concept in 1972. See Peter Dizikes, 'When the butterfly effect took flight', MIT Technology Review, 22 February 2011, www.technologyreview.com/s/422809/when-the-butterflyeffect-took-flight/ (retrieved 21 January 2018).

6 Kevin Oliver, 'Climate dynamics', University of Southampton School of Ocean and Earth Science lecture slides, undated, slideplayer.com/slide/10423511/ (retrieved 21 January 2018). 'Complexity science is the scientific study of complex systems, systems with many parts that interact to produce global behaviour that cannot easily be explained in terms of interactions between the individual constituent elements.'

7 Søren Kierkegaard, Journalen JJ:167 (1843), Søren Kierkegaards Skrifter, volume 18, Søren Kierkegaard Research Center, Copenhagen, 1997, p. 306. 
But hindsight is not necessarily able to tell you what is going to happen when you look forward in time. The current pattern is logical, but it is only one of many patterns that could have been formed, any one of which would have been equally logical. Where we are today is path-dependent, ${ }^{8}$ and arises because of complexity. That is the problem. We cannot predict the future.

Singapore's founding prime minister, the late Mr Lee Kuan Yew, said, 'The past was not preordained, nor is the future. There are as many unexpected problems ahead as there were in the past'. ${ }^{9}$ It sounds like a truism, but it is the reality that governments have to deal with.

\section{The black elephant}

At this point, I would like to introduce another occupant of my menagerie of strategic surprise, the black elephant.

What is a black elephant? It is a cross between a black swan and the elephant in the room. The black elephant is a problem that is actually visible to everyone-the proverbial elephant in the room-but no one wants to deal with it so they pretend it is not there. It is seen to be an improbable event when actually it is not. When the problem blows up, everyone feigns surprise and shock, behaving as if it were a black swan.

All human beings have blind spots. The tendency of the human mind is to underestimate sudden crises, whether because of their own cognitive biases or because it is inconvenient to admit to the obvious. ${ }^{10}$ So initially, through hesitation and until events reach crisis proportions, nobody takes any action. This can lead to military failure-for example, the Japanese attack on Pearl Harbor in 1941 and the Yom Kippur War in 1973.

8 'Path dependence explains how the set of decisions one faces for any given circumstance is limited by the decisions one has made in the past, even though past circumstances may no longer be relevant.' From Jay Barney and William Hesterly, Strategic Management and Competitive Advantage: Concepts, 2nd edn, 2007, Pearson, Upper Saddle River.

9 The then Prime Minister of Singapore, Lee Kuan Yew, speaking at his 60th birthday dinner on 16 September 1983.

10 Cognitive bias: 'Systematic error in judgment and decision-making common to all human beings which can be due to cognitive limitations, motivational factors, and/or adaptations to natural environments.' (A. Wilke and R. Mata, 'Cognitive bias', Encyclopedia of Human Behavior, 2nd edn, vol. 1, ed. V.S. Ramachandran, Academic Press, Cambridge, MA, 2012). 
ISIS is arguably a black elephant. Then US President Barack Obama admitted in September 2014, 'The United States underestimated the threat posed by ISIS fighters in Syria and overestimated the effectiveness of the security forces in Iraq'. ${ }^{11}$ Most recently, we were astonished to learn that the Treasury in the United Kingdom had made no contingency plans for Brexit. ${ }^{12}$ Neither had the British armed forces. In my view, these stand as examples of black elephants in our midst.

\section{Strategic surprise and governance}

One of the pioneer members of the Singapore Cabinet, Mr S. Rajaratnam, was a very forward-looking person with a strategic outlook. In 1979, he said:

There are practical men who maintain that such speculations [thinking about the future] are a waste of time. And they have no bearing at all on solutions to immediate day-to-day problems. This may have been so in earlier periods of history when changes were few and minute, and were spread over decades and centuries. But because we are not only living in a world of accelerating changes but also of changes which are global in scope and which permeate almost all aspects of human activity ... and since change is about the future, then only a future-oriented society can cope with the problems of the 21 st century. ${ }^{13}$

$\mathrm{Mr}$ Rajaratnam was talking about the operating environment of a globalised world in which the pace of change is accelerating. How do we cope with that? We must begin to learn to think systematically about a future that is inherently volatile, uncertain, complex and ambiguous (VUCA) just as we think about the past that is known or knowable.

Anticipating and preparing for change is a profound and critical strategic capability for any government, particularly for military and defence establishments but more generally for all parts of government. Here lies the conundrum that all planners and policy-makers face. How do you

11 President Barack Obama in '60 Minutes' interview on CBS, 26 September 2014, broadcast 28 September 2014, www.cbsnews.com/news/obama-u-s-underestimated-rise-of-isis-in-iraq-and-syria/ (retrieved 30 January 2018).

12 Gemma Tetlow, 'Treasury made no plans for Brexit, says new head, Tom Scholar', Financial Times, 7 July 2016.

13 Speech by S. Rajaratnam, Minister for Foreign Affairs, 'Singapore into the 21st century', seminar, Singapore Association for the Advancement of Science, Singapore Science Centre, 20 December 1979. 
make plans and policies for the long term, knowing that changes in the operating environment are likely to occur within a shorter time frame and that they will inevitably affect or even negate these plans? You make certain assumptions when you launch a big capital project such as a warship or an aircraft. But there inevitably will be changes in technology and the strategic environment. How do you factor these changes, many of which cannot be foreseen, into the planning for such projects that might have life spans for capital platforms of maybe 20, 30 or 40 years?

There is no way we can predict the future. If we could, many of us would be out of jobs. But we can adopt methods and processes that help us reduce the frequency of strategic shock and reduce its amplitude or intensity when the inevitable shock occurs. Strategic studies have an important role to play in each of these tasks.

\section{Scenario planning}

There are foresight methodologies - ways to think about the future systematically and ways that help to overcome some of our latent biases and inherent cognitive constraints. One of them is the famous scenario planning method, which was developed and pioneered by the oil giant Shell. In fact, in 2012, Shell commemorated 40 years of scenario planning. ${ }^{14}$ Shell famously avoided the impact of the oil shock in the 1970s because of scenario planning. But I have not seen much evidence that strategic studies have adopted such tools, perhaps because these foresight methods are too unconventional and maybe because they are perceived to lack academic respectability.

Governments are less constrained, however, because they have to deal with the real world and their imperative is to deliver results. In Singapore, the Ministry of Defence made it an imperative to find ways to better anticipate changes in technology and the operating environment. In the late 1980s, it started using Shell's scenario planning techniques. Then, in 1991, encouraged by Ministry of Defence's positive experiences with scenario planning, a Scenario Planning Office (now called the Strategic

14 Shell has been doing scenario planning since the 1970s to help its leaders explore ways forward and make better decisions. Scenarios ask 'what if?' questions, encouraging leaders to consider events that might be only remote possibilities, to stretch their thinking. Shell scenarios also help governments, academia and business to understand possibilities and uncertainties ahead. 
Policy Office) was set up in the Prime Minister's Office to apply the technique to issues affecting the entire government, not just the defence and security agencies.

Today, scenario planning is a key part of the Singapore Government's strategic planning process. National-level scenario planning exercises are run every few years and are even incorporated into the annual budget cycle. The resultant scenarios are used by ministries and agencies as a base reference for their own strategic planning. Apart from these efforts, which deal with issues on a national scale, focused scenario studies are also carried out on specific issues like climate change or when significant geopolitical change seems imminent.

In the Singapore experience, we have discovered that when scenarios are well crafted and articulate imaginative yet plausible ways in which the future could evolve, planners and policy-makers will move out of their comfort zones, begin to think the unthinkable, and more willingly explore fresh strategies. Scenario planning helps to inculcate an 'anticipatory mindset' in planners and policy-makers so that they instinctively raise 'what if' questions on the issues they deal with.

\section{Beyond scenario planning}

Notwithstanding these benefits, scenario planning also has its limitations. Scenarios alone cannot adequately reflect the complexity of the operating environment. Scenario planning also undervalues the impact of the irrational on future outcomes and, unfortunately, is not very useful in locating the black swans and the unknown unknowns. The Nobel laureate, economist and strategic thinker Thomas Schelling explained, 'One thing a person cannot do, no matter how rigorous his analysis, or heroic his imagination, is to draw up a list of things that would never occur to him'.

We have adopted other tools to address this deficiency in Singapore, even if partially. While scenario planning remains the base, a wider range of foresight tools, such as 'horizon scanning', 'backcasting' and 'causallayered analysis', are now deployed. These tools are collectively referred to as Scenario Planning Plus (SP+). They help planners to uncover and discover some- but certainly not all—of the black swans and unknown unknowns lurking beyond the horizon. 
Horizon scanning ${ }^{15}$ tries to identify the big game-changers by looking for emerging issues and trends and delving into them to see where the threats and opportunities are.

What are the big game-changers now? Some of them are to be found in the current wave of innovation taking place in information technology. This is not only about big data and data analytics. It also includes the Internet of Things, cloud computing, drones, robotics and 3D printing (also known as additive manufacturing).

There have also been significant innovations in other sectors. The shale gas revolution created by fracking technology is part of the reason why oil prices are so low and why the United States is a net exporter of energy. Until recently, many ignored fracking, associating it solely with its potentially negative environmental impact. However, in hindsight, it is clear that this technology has been beneficially disruptive. Massive reserves of shale gas can now be extracted from the ground in the United States through fracking.

But such disruption is not just about innovation and opportunity. There is also a substantial potential downside. Serious people like Bill Gates, Stephen Hawking and Elon Musk have warned that artificial intelligence might pose an existential risk.

Cyber threats are now understood to be very serious. Two years ago, and just a few years after a sophisticated computer worm called Stuxnet was deployed to attack uranium enrichment centrifuges in the Iranian nuclear facility at Natanz, Iranian hackers infiltrated the control system of a small community dam less than 20 miles from New York City. Last year, three power grids in Ukraine were brought down by hackers using techniques similar to Stuxnet. But unlike in a traditional war, it is sometimes difficult to know where or even whether an opponent has struck.

Earlier this year, thieves siphoned US\$81 million from Bangladesh Bank in a sophisticated cyber heist. This was neither the first time nor the last.

15 'Horizon scanning (or environmental scanning) is the systematic process of picking up weak signals and trends and monitor driving forces, potential discontinuities and emerging issues from regular scanning of diverse information sources.' Centre for Strategic Futures and Civil Service College, 'Foresight: A glossary', Singapore, Centre for Strategic Futures, Public Service Division, Civil Service College, undated, www.csf.gov.sg/docs/default-source/default-document-library/csfcsc_foresight--a-glossary.pdf (accessed 18 June 2018). 
With artificial intelligence, drones can fly on pre-programmed routes and might even be able to choose their own targets. Newsweek declared, with some hyperbole, 'Once drones get artificial intelligence, they'll rule the world'. ${ }^{16}$

To top all this off, we see a growing ease of raising money for the new products from technological innovation. Crowdsourcing also made Defense Advanced Research Projects Agency's War Vehicle prototyping process five times faster. Crowdsourcing means that a terrorist can apply online and receive what amounts to a certification to kill.

There are other big issues. Demographics is a perennial. Water is another. Many countries are going to face water shortages because they have carelessly drained their water tables. In other words, they have used up a non-renewable resource: underground water. Furthermore, many other countries are now facing the effects of climate change, such as changing weather patterns disruptions to rainfall. The resulting water shortages are not mere inconveniences. They are an issue of survival and therefore have huge security and strategic implications.

Such emerging strategic issues have the potential to become gamechangers. The question is which ones should we focus on. Which ones are going to evolve into big challenges and be big opportunities? Which others will fizzle out? Strategic studies, complemented by scenario planning and other foresight techniques, can help us to develop a deeper understanding of such issues and to separate the existential from the merely inconvenient.

\section{Singapore's Centre for Strategic Futures}

In 2009, the Singapore Government set up the Centre for Strategic Futures (CSF) ${ }^{17}$ a think tank that promotes a whole-of-government approach to strategic planning. It identifies, adapts and develops foresight and futures thinking concepts and tools for the SP+toolbox, as well as analysing emerging issues for the Singapore Government. Although a

16 Kevin Maney, 'Once drones get artificial intelligence, they'll rule the world', Newsweek, 4 September 2016.

17 CSF's mission is to position the Singapore Government to navigate emerging strategic challenges and harness potential opportunities by building capacities, mind sets, expertise and tools for strategic anticipation and risk management; developing insights into future trends, discontinuities and strategic surprises; and communicating insights to decision-makers for informed policy planning. 
small outfit, the CSF is a catalyst for better foresight and futures thinking in the government and its agencies. Since the establishment of the CSF, several ministries and agencies of the Singapore Government have set up their own foresight or futures units. Giving a small group of people the latitude and the bandwidth to think systematically about the future is going some way to reducing the frequency of strategic surprise and mitigating the impact of such shocks.

\section{Wicked problems and complexity}

This growing network of foresight units has helped Singapore to deal, albeit imperfectly, with wicked problems, ${ }^{18}$ a term coined by design theorists Horst Rittel and Melvin Webber. Wicked problems are highly complex. Their causes and other influencing factors cannot easily be determined. Furthermore, they have multiple stakeholders who see these problems from different perspectives and who have divergent goals. This means there are no immediate or obvious solutions because nobody can agree on what the problems are in the first place, never mind what the solutions are.

Crises are usually wicked problems. Terrorism is a particularly wicked problem. Some of you might be surprised by this assertion because you would think that all of us want to get rid of terrorism-except of course the terrorists. But even if everyone agreed on how to distinguish terrorists from legitimate freedom fighters, and there was consensus that terrorism should be banished, it is not clear that the policy prescriptions would gain universal acceptance. If it were the case, then terrorism would not be the persistent problem that it is today and ISIS would not be such a serious threat.

We mostly work in organisations that respect hierarchy. This is how human systems work. But in a wicked problem where there are multiple stakeholders, more likely than not, there will be different organisations managing only parts of the larger problem. It should be an imperative

18 'A wicked problem that is difficult or impossible to solve because of incomplete, contradictory and changing requirements that are often difficult to recognize. The use of term "wicked" here has come to denote resistance to resolution, rather than evil.' ('Rhetorical terms', in Writing Across the Curriculum, Appalachian State University, undated, wac.appstate.edu/wac-glossary-terms/generalwriting-terms/d-rhetorical-terms (retrieved 21 January 2018, emphasis in original)). 
to be able to bring these different organisations together to address the wicked problem in its totality. In Singapore, we call this the 'whole-ofgovernment' approach.

Tackling the threat of Jemaah Islamiyah $(\mathrm{JI})^{19}$ has been a wicked problem for Singapore. It is not just about removing the immediate threat that the JI posed to Singapore's security. It also requires engaging multiple stakeholders, including community groups. It means engaging the private sector to assist in developing protective systems, processes and infrastructure. This approach clearly needs not just many agencies of government coming together but also bringing in the people and the private sectors. In a way, it is not just a 'whole-of-government ${ }^{20}$ approach but also a 'whole-of-nation' effort. The Singapore approach is to fight the JI network with a 'whole-of-nation' network. This is because JI poses a multidimensional threat that requires collaboration not only among security agencies but also social agencies with oversight of issues affecting local communities. Recently, the Singapore Government introduced the SGSecure movement, which involves bringing together multiple sectors and players to collaborate and coordinate against terrorist threats.

In the context of strategic studies, efforts to understand our complex world often rely on an assumption: that what is complex can be reduced to simpler subsets that are easier to evaluate and that when reaggregated will produce results that approximate the real world.

This approach is reductionism. ${ }^{21}$ Thomas Hobbes, one of the founders of modern political philosophy, argued that all phenomena, including human activity, could be reduced to bodies in motion and their interactions. This assumption gave birth to modern science. It led to the tendency to dissect the world and to favour explanations framed at the lowest level of scale. It is rooted in the belief that complex phenomena can be analysed in component-and simpler-parts. The assumption is that after these

19 JI is a South-East Asian militant Islamist terrorist group dedicated to the establishment of an Islamic caliphate in South-East Asia. JI was responsible for the Bali bombings on 12 October 2002.

20 'A term used in the Singapore Government to describe a networked approach to governance, where officers in different parts of government are able to overcome intra-government differences, e.g. differences in individual agency priorities and tackle problems as a coherent and coordinated whole.' (Centre for Strategic Futures and Civil Service College, 'Foresight: A glossary'.)

21 The practice of analysing and describing a complex phenomenon in terms of its simple or fundamental constituents. 
parts have been analysed separately, it is then possible to understand the properties of the whole in terms of the properties and the interactions of these components.

But despite the enormous importance of this approach, it gives the false impression that investigating the features of things at a holistic level is less informative than investigating the properties of the components. I would argue that strategic studies have tended towards the reductionist approach rather than looking at situations in a more holistic manner.

\section{Net assessments}

A way to offset the problems inherent in the reductionist approach is to employ the net assessment approach, which is done very well in the Australian Office of National Assessments. In many ways, the net assessment approach, pioneered by the US Department of Defense's Office of Net Assessment, which was headed for many years by the legendary Andrew Marshall, is analogous to the 'whole-of-government' approach.

Net assessment ${ }^{22}$ acknowledges that strategic interactions are shaped by the complex sprawling organisations that break big (and wicked) problems into manageable smaller ones. For example, one of the basic ways national security problems are broken down is departmentally between the military and the civilian intelligence community. Each jealously guards its role, and each is concerned about not revealing information that might help an opponent (also known as the doctrine of 'need to know').

This compartmentalisation has had a significant influence on strategy. Problems can be broken down in different ways. For example, an obvious question to ask is whether the military and the civilian intelligence agencies look at an opponent in the same way. Do they see trends similarly?

Such compartmentalisation creates a need for integration. At some point, information from these agencies has to be put together. But while many people assume that this happens automatically, those with a grasp of net

22 Adapted from Paul Bracken, 'Net assessment: A practical guide', Parameters, Spring 2006, pp. 90-100, strategicstudiesinstitute.army.mil/pubs/parameters/articles/06spring/bracken. htm (retrieved 13 March 2018). 
assessment — or of organisational behaviour-understand that nothing is automatic in big organisations, particularly if it involves sharing of information horizontally across vertical silos.

In net assessment, the imperative and the discipline is for information from all sources-and across disciplines - to be shared and evaluated holistically so that complex situations are studied as a whole and not in their parts. This approach helps connect the dots. By thinking broadly, by considering how different events, drivers and agents interact with each other, we can see the larger picture and obtain a better fix on the possible outcomes. In responding to wicked problems, such an approach is not just desirable—it is absolutely critical.

\section{Interdisciplinary thinking}

Net assessment and horizon scanning all require the ability to look at situations holistically. This is important because, as many have said, everything is connected to everything else. We will not see the wood for the trees if we look at each issue from a narrow perspective.

So this is also an argument for strategic studies to move beyond its traditional focus on politics and security and to enlarge its view of the world to see how economics, demographics, societal issues and issues of environment and of technology interact with each other to produce the complexities of the operating environment, a complexity that generates wicked problems, black swans and unknown unknowns. Strategic studies should move into a more interdisciplinary approach rather than study things in their separate domains. It is a counter-reductionist approach. In a research or an academic setting of strategic studies, this approach means that silos should be collapsed in favour of interdisciplinary collaboration.

But it is hard to counter the deep instinct in academia to focus on a single discipline bred out of centuries of reductionism and instead to move towards interdisciplinary collaboration. After all, there are Nobel Prizes for chemistry, physics, economics and medicine, but none for interdisciplinary collaboration. 
Nonetheless, interdisciplinary collaboration is imperative for solving the big challenges of today in science and technology, the social sciences, the economy, urbanisation and the environment. Why not in geopolitics, geostrategy and geoeconomics?

\section{Competing and complementary geographies}

As a penultimate point, I would like to return to the question of whether a South-East Asian perspective exists by pointing out that there is a difference in how people look at issues.

In his study of cultures, The Geography of Thought, ${ }^{23}$ Richard Nisbett identified a major cognitive difference between Western and Asianincluding South-East Asian-cultures. At the risk of oversimplification, after looking at a picture of, say, a horse, Westerners tend to remember the horse. But Asians (including of course South-East Asians) would also recall the background, whether there were clouds in the sky and whether the grass was green. The question is whether strategic studies can normalise this difference, perhaps by taking a more holistic, interdisciplinary and geographically diverse approach. In so doing, the discipline could create a better and a common understanding of the big challenges and issues facing the world.

\section{Conclusion}

Good plans and policies acknowledge the uncertainties and complexities of the operating environment. Strategic studies should likewise acknowledge these uncertainties and complexities to embrace tools of foresight and futures thinking and look at issues holistically. From these they can derive new insights that can help to inform the work of planners and policy-makers.

23 Richard E. Nisbett, The Geography of Thought: How Asians and Westerners Think Differently ... and Why, Free Press, New York, 2003. 


\title{
11
}

\section{American grand strategy in the post-Cold War era}

\author{
Hal Brands
}

The post-Cold War era has now lasted more than a quarter-century. ${ }^{1}$ This period has been an eventful time in US grand strategy. The United States did not withdraw from the world after the Soviet collapse; rather, it recommitted to pursuing a globalism every bit as ambitious as during the bipolar era. It is therefore worth considering what insights the experience of the post-Cold War era have to offer at a time when the international order is often thought to be reaching a new inflection point.

Unfortunately, discussions of the United States' post-Cold War grand strategy are afflicted by three pervasive misconceptions: first, that with the end of the Cold War the United States broke dramatically with its previous grand strategic tradition and undertook a radically new approach to the world; second, that the United States' post-Cold War grand strategy

1 The ideas expressed in this chapter were originally published in Hal Brands, 'US grand strategy: Not so bad after all', American Interest 12, no. 3, 2017, pp. 6-17; and in Chapter 1 of Hal Brands, American Grand Strategy in the Age of Trump, Brookings Institution Press, Washington, DC, 2018. I am grateful to Adam Garfinkle and the American Interest for granting permission to publish a modified version of that article here. 
has been ineffective and even quixotic; and third, that this period of US primacy is now over and that the United States has no choice but to retrench fundamentally as a result. ${ }^{2}$

All three ideas are more myth than reality. The United States did not embrace a radically new grand strategy after the Cold War; it simply adapted its long-standing, post-war grand strategy to a more favourable era of US dominance. That endeavour was hardly fruitless or self-defeating; on balance, it helped to ensure that the post-Cold War system has so far been more stable, liberal and congenial to US interests than many leading observers predicted a quarter-century ago. Finally, although Washington currently faces greater challenges to its international superiority than at any time since the Cold War, the age of US primacy has not yet passed. Accordingly, the time has not come for radical retrenchment; the proper course is rather to sustain the grand strategy that the United States has pursued, fairly successfully, for more than 25 years.

We often see the end of the Cold War as a fundamental point of departure in US foreign relations. ${ }^{3}$ Yet, in reality, the United States' post-Cold War grand strategy is best seen as the logical extension of an approach that originated following World War II. For US officials, World War II demonstrated the basic interdependence of the world environment and the corresponding need to define national security in global terms. Accordingly, the post-war decades saw a sustained US activism meant to construct an overarching international order that would be congenial to the security of the United States as well as its liberal values.

Throughout the post-war era, US officials consistently promoted an open, liberal economy, and they sought to preserve a peaceful international environment in which democracy and human rights could flourish. They worked to create stability and security in key regions from Europe to the Middle East to East Asia and to prevent any hostile power from

2 For works expressing some or all of these ideas, see Stephen Walt, 'The end of the American era', National Interest, no. 116, 2011, pp. 6-16; John Mearsheimer, 'Imperial by design', National Interest, no. 111, 2011, pp. 16-34; Michael Mandelbaum, Mission Failure: America and the World in the Post-Cold War Era, Oxford University Press, New York, 2016; Michael Mandelbaum, 'America in a new world', American Interest 11, no. 6, 2016; Christopher Layne, 'The unipolar illusion revisited: The coming end of the United States' unipolar moment', International Security 31, no. 2, 2006, pp. 7-41.

3 This is, admittedly, a view to which I contributed in an earlier book: Hal Brands, From Berlin to Baghdad: America's Search for Purpose in the Post-Cold War World, University Press of Kentucky, Lexington, 2008. 
dominating these regions either by force or otherwise. They strove to maintain an overall global balance of power that favoured the United States and its Western allies and to contain and roll back the influence of aggressive authoritarian states. And in support of all this, the United States undertook global commitments-from security guarantees and overseas force deployments to leadership of international trade pacts and institutions - that were designed to project US influence around the world. During the Cold War, these endeavours helped foster a thriving international order in the West and to contain - and ultimately defeatMoscow's rival order in the socialist bloc. ${ }^{4}$

When the Cold War ended, then, US officials did not have to chart a radical new course in United States' foreign policy. Rather, they simply adapted the country's successful post-war grand strategy to a new age of unipolarity. The United States emerged from the Cold War with clear military, economic and diplomatic primacy and at the head of a dominant Western coalition. In these circumstances, Washington effectively doubled down on its post-war statecraft.

The long-standing goal of maintaining favourable balances of power both globally and within key regions, for instance, became one of sustaining the remarkable US and Western overmatch that the Soviet collapse had produced. The goal of fostering an environment in which democracy could flourish evolved to include more actively promoting democratic institutions in countries around the globe. The goal of creating a robust liberal economy in the non-communist world became one of promoting deeper integration in the First World while spreading market institutions into the former Second and Third worlds. And the goal of containing and ultimately defeating the Soviet Union became one of preventing any new threat-from international terrorism to nuclear proliferation and the actions of aggressive 'rogue states'-from rising to the level of the former Soviet menace or otherwise bringing the good times to an end.

In sum, the United States' post-Cold War grand strategy focused on preserving US international primacy, deepening and extending the liberal order, and suppressing any dangers that threatened to disrupt this benign international environment. This strategy was first explicitly spelled out

4 See, for instance, G. John Ikenberry, Liberal Leviathan: The Origins, Crisis, and Transformation of the American World Order, Princeton University Press, Princeton, 2011. 
in the Pentagon's 1992 Defense Planning Guidance; it was subsequently adopted - with some variation in focus, tone and emphasis-by every post-Cold War administration that followed. ${ }^{5}$

This strategy, moreover, was pursued by concrete initiatives that also represented as much continuity as change. Every post-Cold War administration emphasised maintaining the United States' globestraddling military posture as the hard-power backbone of the unipolar international order. Similarly, every post-Cold War administration preserved and even extended the United States' Cold War-era alliances and security commitments to lock in stability and US influence in key regions, and to provide the security blanket that would help sustain and extend the liberal order. With respect to the global economy, every postCold War administration continued to pursue international economic integration through institutionalisation of liberal economic practices, liberalisation of global currency and capital flows, and pursuit of freetrade agreements from North American Free Trade Agreement (NAFTA) in the early 1990s to the Trans-Pacific Partnership today. And every administration continued to contain and confront aggressive actors that threatened the smooth functioning of the international system-from Saddam Hussein's Iraq to a perpetually provocative North Korea-through economic, diplomatic and military means. Finally, even in those cases where US policy did become more assertive following the Cold Waras in the case of promoting democracy - that policy followed essential precedents set by Cold War-era initiatives from the Marshall Plan to the encouragement of liberal political reforms by the Carter and Reagan administrations. US statecraft from the early 1990s onward did not break sharply with the past; it built upon foundations laid by a successful postwar grand strategy.

None of this is to say that there was no change in US grand strategy after the Cold War or that there was perfect consistency across postCold War administrations. The United States did undertake some new endeavours in the unipolar era, the practice of humanitarian military intervention - an unaffordable luxury during the Cold War-in countries from Somalia to Libya being perhaps the most notable. After 9/11,

5 On post-Cold War grand strategy, see Hal Brands, Making the Unipolar Moment: US Foreign Policy and the Rise of the Post-Cold War Order, Cornell University Press, Ithaca, 2016; Peter Feaver and Stephen Biddle, 'Assessing strategic choices in the War on Terror', in How 9/11 Changed Our Ways of War, ed. James Burk, Stanford University Press, Stanford, 2014, esp. pp. 29-31. 
moreover, the assertiveness with which the United States pursued many of its goals jumped significantly, as manifested most clearly in the invasion of Iraq. And from George H.W. Bush to Barack Obama, US presidential administrations have differed on many things, from their rhetorical styles to their approaches to using force.

Yet focusing on these differences obscures the basic continuity of postCold War grand strategy as well as the extent to which that grand strategy has been rooted in the broader tradition of post-war statecraft. In 1950, the authors of National Security Council Report 68 (NSC-68) stated that efforts 'to foster a world environment in which the American system can survive and flourish' constituted 'a policy which we would probably pursue even if there were no Soviet threat'. ${ }^{6}$ The trajectory of US grand strategy after the Cold War showed the truth of this statement.

A second myth regarding the United States post-Cold War grand strategy is that this strategy has been quixotic and even 'disastrous' - that Washington has wasted its primacy by tilting at geopolitical windmills. ${ }^{7}$ This verdict is influenced heavily by the United States' long wars in Iraq and Afghanistan, embroilments that have ranged from unsatisfying to remarkably self-defeating in their effects. And throughout the post-Cold War period there have been mistakes of omission and commission, failures of conception and implementation, and examples of hubris and blowback in US policy. From the humiliating failure of US intervention in Somalia in 1993 to the fallout from an initially successful intervention in Libya in 2011, there is plenty to lament and criticise.

Yet doing so risks missing the forest for the trees. Because, for all its travails, US strategy has played a central role in making the post-Cold War system more stable, more liberal and more favourable to US interests than it would have been otherwise-and certainly in producing a more benign global environment than many expert observers expected in the early 1990s. Indeed, just as it is now widely accepted that US Cold War

6 National Security Council 68 (NSC-68), 'United States objectives and programs for national security', 14 April 1950, fas.org/irp/offdocs/nsc-hst/nsc-68.htm (retrieved 30 January 2018).

7 Mearsheimer, 'Imperial by design', p. 16; also Barry Posen, 'Pull back: The case for a less activist foreign policy', Foreign Affairs 92, no. 1, 2013, pp. 116-29. 
grand strategy was broadly successful despite the frustrations and failures that occurred along the way, when it comes to shaping the international system, the overall record of US post-Cold War engagement has actually been fairly impressive.

To grasp this point, think about some of the most prominent forecasts about the future of international politics made just after the Cold War's end. There were, certainly, some very sunny predictions to emerge in the late 1980s and early 1990s. But there were also some very pessimistic ones.

Most leading international relations theorists initially believed, for example, that the unipolarity the United States enjoyed following the superpower conflict was inherently unsustainable - that it would promptly cause renewed Great Power balancing and the rise of countervailing coalitions. Moreover, many such observers worried that the end of the Cold War would lead not to a stable, liberal peace but to vicious, multipolar instability. Bipolarity had suppressed sources of violence and anarchy in international affairs; bipolarity's collapse would surely unleash these influences. A revanchist Japan and Germany, the emergence of sharp security competitions in Europe and East Asia, rampant nuclear proliferation and aggressive behaviour in the world's key strategic theatres: these were among the pernicious phenomena expected to materialise after bipolarity's demise. 'We will soon miss the Cold War,' John Mearsheimer warned. 'The prospect of major crises, even wars ... is likely to increase dramatically now that the Cold War is receding into history.' ${ }^{8}$

Yet whatever the imperfections of the post-Cold War era, these dogs mostly did not bark. By most meaningful comparisons, the period since the Cold War has been a time of relative international peace, stability and liberal progress. Until very recently, for instance, Great Power tensions remained remarkably low compared to the Cold War, or to any period dating back to the Concert of Europe. Regions such as East Asia and Europe have been mostly free of interstate conflict, and German or Japanese revanchism has been conspicuously absent. Nuclear proliferation has occurred via rogue actors such as North Korea, but on the whole it has advanced much more slowly than many would have predicted.

8 John Mearsheimer, 'Why we will soon miss the Cold War', Atlantic Monthly 266, no. 2, 1990, pp. $35-50$. 
Meanwhile, democracy continued its advance after the Cold War with the number of electoral democracies growing from 76 in 1990 to 120 in the early 2000s. ${ }^{9}$ Economic integration and the spread of free markets continued, and global living standards kept rising. Not least, predictions of a rapid return to unstable multipolarity proved mistaken. Instead, the United States retained a vast economic and military lead over any competitor through the end of the millennium and beyond, and many of the world's second- and third-tier powers generally sided with, rather than against, the world's sole superpower. There remained opposition to US power, of course, some of it violent, and some of it encouraged by the United States' own policies. And from catastrophic terrorism to ethnic violence, there remained significant sources of tension and conflict in international affairs. But relative to what might have been expected, the post-Cold War period was not half bad.

There were numerous reasons for this, of course. But international politics are prominently shaped by the policies of the system's leading power, and after the Cold War the United States had as much capacity to shape the system as any other great power in modern history. And indeed, US grand strategy played an essential role in making the post-Cold War order as favourable as it has been.

The maintenance of US military presence and alliances in Europe and East Asia helped to tamp down potential instability, for instance, and keep historical powers such as Japan and Germany anchored firmly to the West. ${ }^{10}$ Likewise, the extension of US alliance commitments to Eastern Europe helped to smother incipient conflicts and security dilemmas following the breakdown of Soviet hegemony and reduced pressures for nuclear proliferation or major military build-ups by historically insecure states such as Poland or Romania. In the Balkans, the US-led military interventions that occurred in 1995 and 1999 were admittedly belated and hesitant. Yet they nonetheless helped to end ethnic cleansing in south-eastern Europe and to douse persistent conflicts before they could destabilise south-eastern Europe more broadly.

9 See Freedom House, Freedom in the World 2013: Democratic Breakthroughs in the Balance, 2013, p. 29, freedomhouse.org/report/freedom-world/freedom-world-2013.

10 This is a point conceded by some leading critics of US policy. See John Mearsheimer, 'Why is Europe peaceful today?', European Political Science 9, no. 2, 2010, pp. 387-97. 
Nor were these the only areas where US policy had such effects. In the former Soviet space, proactive US diplomacy helped to achieve the denuclearisation of Ukraine, Belarus and Kazakhstan, and dramatically reduced the danger of 'loose nukes' by helping Russian officials secure poorly guarded nuclear materials. And in dealing with international outlaws such as Iraq or North Korea, US policy helped to keep rogue regimes in check, and prevented them from dominating or further destabilising key regions. In sum, US engagement suppressed renascent geopolitical competition and upheaval in key areas, and provided the reassurance that permitted global economic integration and other positive trends to continue pushing forward.

US policy affected the contours of the post-Cold War order in other ways too. Direct US engagement helped to create and strengthen international economic institutions such as the World Trade Organization, foster an array of regional and bilateral free trade pacts, and bring the single most important non-Western economy-China-into the international economic order to an unprecedented degree. In countries from Guatemala in the early 1990s to Georgia in the early 2000s, US support helped to strengthen democratic reformers and pressure authoritarian rulers. Finally, the fact that Washington maintained relatively robust military spending during the early 1990s and after helped to ensure that the international order did not swing back towards unstable multipolarity but rather remained distinctly unipolar into the early 21 st century.

US policy was not solely responsible for these developments, but it was the common thread that tied them together. If the goal of US post-Cold War strategy was to sustain and deepen a stable, liberal order in which the United States enjoyed clear primacy, then that strategy would have to be considered—on balance—a success.

But does the United States still enjoy that primacy, and can it sustain such an ambitious strategy in the future? The answer one increasingly hears is 'no'-that the world is rapidly entering a new era of multipolarity, and that Washington has no choice but to retrench markedly as a result. ${ }^{11}$

11 Christopher Layne, 'This time it's real: The end of unipolarity and the Pax Americana', International Studies Quarterly 56, no. 1, 2012, pp. 203-13. 
This argument is not baseless, for the United States' margin of superiority has slipped from its post-Cold War peak. In 1994, the United States accounted for roughly 24.7 per cent of global gross domestic product (GDP) and 38.8 per cent of world military spending, rising to 25.2 and 40.7 per cent respectively in 2004. By 2014, those numbers had fallen to 22.4 per cent of global GDP and 33.8 per cent of world military spending. The share of global wealth and power wielded by the United States' core treaty allies had also declined-from 47.1 per cent of global GDP and 36.3 per cent of global military spending in 1994 to 39.3 and 25.9 per cent, respectively, in 2014 - as that wielded by the chief challenger to US primacy had risen dramatically. In 1994, China accounted for just 3.27 per cent of global GDP and 2.2 per cent of world military spending; by 2014 , those numbers were 11.4 and 11.4 per cent. ${ }^{12}$

As the global power gap has narrowed, Washington has also been faced with more-and arguably more severe - threats to its position than at any time since the Cold War. Great Power competition has returned as Russia and China test the contours of an order that they never fully accepted and that they now have greater capacity to challenge. Moscow and Beijing are seeking to assert primacy within their own regions; they are probing the distant peripheries of the US alliance system; they are developing military capabilities that are threatening the United States' ability to project power and uphold its security commitments in Eastern Europe and the western Pacific.

Meanwhile, the long-standing challenge of handling rogue actors has also become more difficult as those actors have become more empowered. North Korea boasts a sizeable nuclear arsenal and is reportedly developing an intercontinental strike capability. Iran is fanning sectarianism, fighting multiple proxy wars and destabilising an already disordered Middle East as it also emerges from punishing international sanctions. The Islamic State is losing ground militarily, but it has shown the capacity of non-

12 Defence spending figures in this paragraph are drawn from the Stockholm Peace Research Institute's (SIPRI) annual data on global military spending. GDP figures are drawn from Economic Research Service, US Department of Agriculture (USDA), 'GDP Shares by country and region historical', www.ers.usda.gov/data-products/international-macroeconomic-data-set/ (retrieved 30 January 2018). Figures on US allies include the North Atlantic Treaty Organization (NATO) countries plus US treaty allies in Asia and Taiwan (thanks to its quasi-ally status as enshrined in the Taiwan Relations Act). These figures were calculated at the time this article was initially published, in 2016; the SIPRI database has been periodically updated since then. 
state actors to sow chaos across a crucial region while also spreading and inspiring terrorism across the globe. In so many areas, the United States confronts rising challenges to the post-Cold War order.

The world ideological climate is becoming more contested as well. After being in retreat for decades, authoritarian regimes are becoming increasingly tenacious in pushing back against liberalising currents as the 2008-09 global financial crisis and its aftermath have raised questions about whether democracies can deliver the goods. Russia, China and other authoritarian regimes have meanwhile re-entered the global ideological competition in more significant ways, touting the virtues of centralised control and 'state capitalism' and pushing back against Western concepts of political liberalism and human rights. Even countries that are part of the US-led alliance system have regressed politically; Hungarian prime minister Viktor Orban has proclaimed the rise of the 'illiberal state' as an antidote to the weaknesses of liberal democracy. As a result of all this, the advance of electoral democracy has largely stalled over the past decade, and some analysts contend that a 'democratic recession' is underway. ${ }^{13}$

Finally, there are questions about the trajectory of the United States' own engagement with the world. The United States experienced significant real declines in defence spending from 2010 to 2017. The wars in Iraq and Afghanistan have fanned pro-retrenchment sentiment at home; Americans now seem less convinced of why the United States should retain such an assertive global strategy. According to one poll conducted in 2013, 52 per cent of Americans believed that the country should now 'mind its own business internationally and let other countries get along the best they can on their own'. ${ }^{14}$ These factors have collectively fed into a narrative of national decline more pronounced than at any time since the 1970s.

Yet if this narrative is not baseless, it is badly overstated. For the idea that the era of US primacy has passed-and that we are now entering, or have already entered, a multipolar world —is far from being true. By virtually all key metrics, the United States still has substantial leads over its closest competitors. In 2015, the United States claimed a GDP of nearly $\$ 18$ trillion, which was roughly $\$ 7$ trillion larger than China's, and

13 Larry Diamond, 'Facing up to the democratic recession', Journal of Democracy 25, no. 1, 2015, pp. 141-55.

14 Paul Lewis, 'Most Americans think US should "mind its own business" abroad, survey finds', Guardian, 3 December 2013. 
it possessed a per capita GDP roughly four times that of China. In the military realm, US annual defence spending was still nearly three times that of China. ${ }^{15}$

In fact, the United States' global lead is probably far more significant than simple numerical measures like GDP and percentage of global military spending indicate. GDP is a commonly used but highly problematic way of comparing US and Chinese economic strength. This is because it is merely a snapshot rather than a fully satisfying measure of how wealth accrues over time because it does not account for such factors as the damage that China is doing to its own long-term economic potential through the devastation of its natural environment, and because it understates important US advantages, such as the fact that US citizens own significant shares in foreign corporations. By a more holistic measure of national economic strength'inclusive wealth', which takes account of manufactured capital, human capital and natural capital - the United States was still roughly 4.5 times wealthier than China as recently as $2010 .^{16}$

The US military lead is even more extensive. As one detailed study by William Wohlforth and Stephen Brooks concludes, although China's continuing military build-up presents significant regional challenges for the United States, at the global level there is simply no comparison. The United States possesses massive advantages in high-end power-projection capabilities such as aircraft carriers, fourth- and fifth-generation tactical aircraft, nuclear-powered submarines and the Airborne Warning and Control System (AWACS). These advantages have been amassed over decades, and so it will take decades - if not longer-for China to come close to matching the United States. These metrics, moreover, do not reflect other, more intangible US advantages: the years of recent operational experience, the extraordinarily high levels of human capital, and others. As Brooks and Wohlforth write:

Rather than expecting a power transition in international politics, everyone should start getting used to a world in which the United States remains the sole superpower for decades to come. ${ }^{17}$

15 For these figures, see World Bank, 'GDP (current US\$)', data.worldbank.org/indicator/NY.GDP. MKTP.CD (retrieved 30 January 2018); World Bank, 'GDP per capita, PPP (current international \$)', data.worldbank.org/indicator/NY.GDP.PCAP.PP.CD (retrieved 30 January 2018); also the SIPRI military spending data referenced above.

16 Stephen Brooks and Willian Wohlforth, 'The rise and fall of the great powers in the twenty-first century', International Security 40, no. 3, 2015-16, pp. 7-53, esp. pp. 31-2.

17 Stephen Brooks and William Wohlforth, 'The once and future superpower: Why China won't overtake the United States', Foreign Affairs 95, no. 3, 2016, pp. 91-104, esp. pp. 91-2. 
Finally, any consideration of global power dynamics must consider the role of allies; namely, the fact that the United States has dozens whereas challengers like China and Russia have few, if any. The United States' allies give it geopolitical leverage, diplomatic influence and military access that other countries can only envy; they add enormously to the overall weight of the Western coalition. As of 2014, the United States and its core treaty allies in Asia and Europe accounted for roughly three-fifths of global wealth and global military spending - a share that was moderately diminished compared with two decades earlier but still enormously impressive. ${ }^{18}$

In sum, US primacy might ultimately vanish, but that day is still a long way off. So, rather than abandoning a grand strategy that has worked fairly well, the United States should instead work to sustain that grand strategy for a period in which its primacy remains impressive, if more contested than before.

\section{IV}

Doing so requires embracing five basic principles. First, American officials and public observers need to scope the grand strategy debate right. Every four years, there is a flurry of proposals for some 'new grand strategy for America'. Yet the United States does not need a fundamentally new grand strategy. It already has one that has worked fairly well and remains broadly consonant with global power realities today. The focus of the debate, then, should be on adapting a generally successful approach at the margins rather than coming up with something radically new from scratch.

Second, and more specifically, the United States will need to shore up the military foundation of its grand strategy by reinvesting in defence. Military power is hardly the only tool of US policy, but US military dominance has been a fundamental enabler of US global influence and international stability over the past quarter-century. And for all of the United States' globalist ambitions, maintaining that military dominance has actually been quite affordable during the post-Cold War era. At the peak of the superpower contest, US military spending consumed 10-12 per cent of

18 See the SIPRI and USDA statistics for 2014 cited in footnote 12. 
GDP; since the mid-1990s, the number has usually been between 3 and 4 per cent. In a relatively benign environment, Washington has had primacy on the cheap. ${ }^{19}$

Today, however, the United States is reaching the limits of this approach. At present, the demands on US defence dollars are becoming greater than at any time in the post-Cold War era. Yet US defence dollars became scarcer after 2010 as defence budgets fell towards 3 per cent of GDP. ${ }^{20}$ Even the more recent increases in the defence budget under the Trump Administration are unlikely to fully correct this earlier decline. These trends of increasing threat and insufficient resourcing are ultimately unsustainable — at some point, they will erode the military foundation of US grand strategy and undercut the credibility of US commitments, thereby jeopardising the stability and influence that US strategy has provided. Put another way, the United States can probably preserve an acceptable level of military primacy if it is willing to spend 4 per cent of GDP on defence and to focus that spending on investments such as the anti-access/anti-denial (A2/AD)-busting capabilities that are needed to preserve US deterrence and power projection in increasingly contested regions. It probably cannot do so at 3 per cent of GDP or below.

Third, and related, the United States needs to firm up the coalition aspect of its grand strategy by getting more out of - and diversifyingits relationships with allies and partners. Its post-Cold War primacy has always rested on its leadership of a community of capable, like-minded nations. Yet, as noted previously, the share of global wealth and power held by the United States' core treaty allies has fallen over the past two decades, from 47.1 per cent of global GDP and 36.3 per cent of global military spending in 1994 , to 39.3 per cent and 25.9 per cent, respectively, in $2014 .{ }^{21}$ US primacy might be intact, but the overall relative strength of the US-led coalition is slipping.

19 See John Lewis Gaddis, Strategies of Containment: A Critical Appraisal of American National Security Policy during the Cold War, Oxford University Press, New York, 2005, p. 393; World Bank, 'Military expenditure (\% of GDP)', data.worldbank.org/indicator/MS.MIL.XPND.GD.ZS (retrieved 30 January 2018).

20 Loren Thompson, 'Pentagon budget headed below 3\% of GDP as warfighting edge wanes', Forbes, 2 February 2015.

21 These figures are drawn from the SIPRI and USDA data cited in footnote 12. 
There are two principal pathways to addressing this challenge. One is by getting more out of existing US allies, by pushing them to embrace policies that will stretch resources further. Encouraging greater defence specialisation and resource-sharing within the North Atlantic Treaty Organization (NATO), pushing Asian and Eastern European allies to adopt more cost-effective defence strategies based on anti-access/area denial, and fostering greater multilateral ties between allies (particularly in Asia) all represent ways of getting more allied bang for the buck. Likewise, as Washington increases its own commitments to Europe and the Asia Pacific, it should make clear that additional US activity is contingent upon US allies doing more too.

Equally important, the United States should offset the relative decline of some traditional allies by building and deepening newer partnerships. Global power is not just shifting to rivals of the United States-it is also shifting to states that are formally non-aligned but are nonetheless willing to work with Washington and its allies on critical international issues. India, Brazil, Indonesia, Vietnam and the United Arab Emirates are just a few of these countries; they have forged deeper ties with the United States on issues ranging from counter-terrorism to maritime issues to regional security in the Middle East and the Asia-Pacific. By building and improving flexible partnerships with such states, the United States can position itself to sustain a global imbalance of power in support of key aspects of the international order.

Fourth, even as the United States focuses on shoring up the partnerships and power that make its grand strategy possible, it must also show great discipline in employing that power. US strategy has arguably been most successful when it has focused on preserving the basic stability and wellbeing of the international system and creating broad conditions in which political and economic liberalism can advance. Conversely, the United States has got into trouble when its immense power has encouraged strategic indiscipline via the overestimation of its ability to transform foreign societies rapidly or overreach in the use of military force. Such strategic indiscipline is invariably punished through unforeseen and unwelcome geopolitical consequences abroad and diminished public support for robust US internationalism. At a time when the US margin of superiority has eroded from its post-Cold War peak, strategic profligacy is a luxury that Washington can no longer afford. 
To be clear, maintaining strategic discipline does not mean foreswearing all uses of force. Nor does it mean forsaking the active promotion of democracy and human rights. For there are occasions in which limited, coercive uses of force are appropriate to protect US interests in key regions - think of the Balkan interventions during the 1990s. There are cases in which threats to the international order can be met only by forcethink of the Islamic State more recently. There are alliance commitments that must ultimately be backed by force when necessary. Finally, the nonmilitary aspects of democracy promotion will have a key role to play in the more competitive ideological environment that is now emerging.

But being disciplined does require a sense of limits and humility. It requires recognising the limitations of military force as a tool of political transformation in historically illiberal societies. It requires accepting that there are problems and injustices that not even a superpower can solve, and that wisdom lies in discerning where US interests are most implicated and where US power can make the critical difference. Great power must be rationed as well as exploited if it is to be effective and enduring; acknowledging this point represents a fourth principle for US strategy.

Fifth and finally, sustaining the United States' post-Cold War strategy entails persuading the American public to recommit to that strategy. The state of US opinion on that subject is currently ambiguous. Polling data indicates that public support for most key aspects of US internationalism has recovered somewhat from where it was in 2012-13 and is again at or near post-World War II averages. ${ }^{22}$ But the 2016 election cycle revealed strong support for candidates who have advocated rolling back key elements of post-Cold War (and post-World War II) grand strategy, from free trade to US alliances.

Sustaining US grand strategy will thus require more intensive political efforts. US leaders will need to take up more strongly the case for controversial but broadly beneficial policies such as free trade. They will need to articulate more fully the underlying logic of alliances and other commitments whose costs are often more visible than their benefits. Not least, they will need to make the case that the burdens the country has borne in support of that order are designed to avoid the necessity of bearing far heavier burdens if the international scene returned to a more 
tumultuous state. The success of US statecraft is often reflected in the bad things that do not happen as well as the good things that do. Making this point is essential to reconsolidating domestic support now and in the future.

\section{V}

Contrary to the common caricatures, the United States' post-Cold War grand strategy has not marked a radical departure from the country's previous statecraft; it has not been a catastrophic failure, and it has not been irrevocably overtaken by global power shifts. Rather, the United States' post-Cold War approach has been rooted firmly in its successful post-war strategic tradition, and it has been broadly effective in moulding the international system to Washington's liking. Moreover, while the global environment is becoming more contested today, that grand strategy can still be sustained if US officials embrace the proper principles. Of course, adapting an existing model is less exciting than forging a wholly new one. But this is nonetheless a worthy endeavour in view of the pretty successful record of US grand strategy over a quarter-century. 


\section{2}

\section{The future of strategic studies: Lessons from the last 'golden age'}

\section{Hew Strachan}

In 1945, as World War II ended, Bernard Brodie was aged 35, a young scholar newly employed at Yale's Institute of International Studies. He had completed a doctorate at Chicago, published Sea Power in the Machine Age in 1941, and in the following year followed it with a brief introduction to the subject: A Layman's Guide to Naval Strategy. Brodie prefaced his second book with a combative introduction:

We are being told on every hand that we must repudiate all the ideas of the past and develop a whole new strategy overnight ... But what is required is an attitude of fine discrimination and adjustment, not nihilism. The war of to-day is being fought with new weapons, but so was the war of yesterday and the day before. Drastic change in weapons has been so persistent in the last hundred years that the presence of that factor might be considered one of the constants of strategy. Only those to whom the study of war is novel permit themselves to be swept away by novel elements in the present war. 
He went on to refer to the titans in the field of maritime strategy: Alfred Thayer Mahan, Julian Corbett and Raoul Castex, 'the underlying value' of whose teachings 'is still largely intact'. ${ }^{1}$ In this approach, Brodie followed that adopted by Edward Mead Earle of Princeton's Institute for Advanced Study under whose tutelage he had adapted his thesis for publication and to whose wartime seminar series on the making of modern strategy Brodie contributed. In 1943, those seminars (albeit not Brodie's) were published by Earle in The Makers of Modern Strategy: Military Thought from Machiavelli to Hitler. ${ }^{2}$ Earle's book remained the standard text on the evolution of strategic thought well into the 1970s, and was finally supplanted only in 1986 when Peter Paret published a new and updated version. ${ }^{3}$ So pervasive was Earle's influence that he has recently been credited with the establishment of security studies in the United States, and by implication with being present at (and possibly even the author of) the dawn of the 'last golden age' in the study of strategy. ${ }^{4}$ Yet, like Brodie's own works on maritime strategy, the content of The Makers of Modern Strategy is overwhelmingly historical, and indeed it looks the more dated (and often simply wrong) the closer it gets to its own times. ${ }^{5}$ In other words, Earle, like Brodie, looked backwards to think forwards.

On 6 August 1945, the United States dropped the first atomic bomb on Hiroshima. The next day, Brodie tells us, he was travelling in a car with his wife when he stopped to buy a copy of the New York Times. He read the report of the attack and then turned to his wife to say, 'Everything I have ever written is obsolete. ${ }^{6}$ Like so many renderings of damascene moments, Brodie's story probably improved with the telling. Any student of Brodie's subsequent writings on strategy has little difficulty in tracing the continuing influence of his early education beyond 1945, not least in

1 Bernard Brodie, A Layman's Guide to Naval Strategy, Oxford University Press, London, 1943 (first published Princeton University Press, Princeton, 1942), pp. viii-ix. This essay develops themes that will be familiar to readers who have read my book, The Direction of War: Contemporary Strategy in Historical Perspective, Cambridge University Press, Cambridge, 2013. I am arrogant enough to believe that they need repetition but modest enough to recognise that they also need development.

2 Edward Mead Earle, Gordon Alexander Craig and Felix Gilbert, Makers of Modern Strategy: Military Thought from Machiavelli to Hitler, New York, Atheneum, 1967.

3 Peter Paret, with Gordon A. Craig and Felix Gilbert (ed.), Makers of Modern Strategy from Machiavelli to the Nuclear Age, Clarendon Press, Oxford, 1986.

4 David Ekbladh, 'Present at the creation: Edward Mead Earle and the depression-era origins of security studies', International Security 36, no. 3, 2011-12, pp. 107-41.

5 Michael P.M. Finch, 'Edward Mead Earle and the unfinished Makers of Modern Strategy', Journal of Military History 80, no. 3, 2016, pp. 781-814.

6 Barry Scott Zellen, State of Doom: Bernard Brodie, the Bomb, and the Birth of the Bipolar World, Continuum, London, 2012, pp. 24, 27-30. 
his last published work, the guide to reading Clausewitz's On War, which appeared as an appendix to Michael Howard and Peter Paret's translation in 1976 and which too many harassed students have used as a substitute for reading the real thing. ${ }^{\text {? }}$

In the short term, however, Brodie followed his shocked response to the advent of nuclear weapons by unravelling the reasons for his instinctive reaction. The result, published in 1946, was The Absolute Weapon: Atomic Peace and World Order, which declared, 'Thus far the chief purpose of our military establishment has been to win wars: from now on its chief purpose must be to avert them'. ${ }^{8}$ For most students of strategy, The Absolute Weapon is a better marker than Earle's Makers of Modern Strategy for the arrival of the 'golden age', the moment when civilians began to take over the study of strategy and when its purpose became the avoidance of war through deterrence, not its conduct through fighting.

It would be patently absurd to argue that the 'golden age' was constructed without a backward glance to history. When the news of Hiroshima and Nagasaki broke, Basil Liddell Hart was reflecting on the experiences of World War II for a book that was already called The Revolution in Warfare. He did not jettison his conclusions, which he had already written and which began by stating that 'the future is moulded by the past', and averred that 'the best promise for the future lies in understanding, and applying, the lessons of the past'. Liddell Hart added an epilogue on the atomic bomb after the book's completion, but it did not lead him to withdraw this statement. Instead of becoming a summons to avoid all war, The Revolution in Warfare reasserted the need to understand and apply the principles that would limit it. ${ }^{9}$

Over the next decade, both currents would develop in strategic thoughtone seeking to prevent war and one seeking to recognise wars would happen but had to be contained. However, neither current rejected the idea that 1945 was a caesura: as the Cold War took hold, that seemed to apply to the international system as a whole, and it was easy, if lazy, to relate it to strategic studies specifically.

7 Carl von Clausewitz, On War, ed. and trans. Michael Howard and Peter Paret, commentary Bernard Brodie, Princeton University Press, Princeton, 1984.

8 Bernard Brodie, 'The absolute weapon', in Thomas G. Mahnken and Joseph A. Maiolo (eds), Strategic Studies: A Reader, Routledge, London, 2008.

9 B.H. Liddell Hart, The Revolution in Warfare, Faber, London, 1946, p. 76. For a revised attempt at the same points, see the US edition, published by Yale University Press in 1947. 
The study of strategy was presented with a disciplinary crisis. It no longer rested primarily on the history of war. Brodie's supervisor at Chicago, Jacob Viner, was an economist, not a historian, and that was before the bomb was dropped. The strategist of the nuclear age whose influence has been most persistent, particularly when judged from a post-Cold War vantage point, is probably another economist, Thomas Schelling. Schelling brought to strategy the perspectives of social science, game theory and mathematics. ${ }^{10}$ The study of strategy moved from being heavily experiential (meaning based on experience rather than on scientific experiment) to being heavily theoretical. From having turned overwhelmingly to the past for its inspiration, it turned disproportionately to the future. These new trajectories were entirely positive in themselves, but they had a displacement effect. History was dismissed too readily and completely from the study of strategy in the 'golden age', and that provides an object lesson as we address lessons for the study of strategy in the future.

Strategic thought until 1945 had sought continuities. It was a dialogue between the present and the past. It gave context to current conflicts by setting them against those that had gone before. It assumed, as Clausewitz did, that war had a universal nature and that, while its study was informed by current experience, the immediacy of the present could be given meaning only by comparing it with the past. Moreover, when handled well, it did not stop at demonstrating continuity. It recognised that any soldier is powerfully shaped by his own experience. War is intense, demanding and potentially overwhelming. However, one person's adventures are not necessarily typical, although of course they can be, and so individual experience, however formative, is not in itself sufficient for the making of strategy. History is required in order to understand what is really new, what has changed and what seems to be new but might not be. History enables us to discriminate between what might be exceptional and unique in personal experience, what might be fundamentally new and perhaps lasting, and what is already familiar.

This was exactly how Jomini and Clausewitz had approached the study of Napoleonic strategy. They used the Seven Years War as a benchmark against which to comprehend better the wars of their own times, and it was how Mahan and Corbett used Britain's 18th-century conflicts the

10 See Robert Ayson, Thomas Schelling and the Nuclear Age: Strategy as Social Science, Frank Cass, London, 2004. 
better to understand naval war at the turn of the 19th and 20th centuries. The dramatic and seemingly 'revolutionary' changes of World War I might have been expected to rupture strategy's relationship with history. Giulio Douhet certainly said as much in Command of the Air in 1921, but in practice he referred back to the war to make his argument and so made his case for change by using the past. As others reflected on World War I, J.F.C. Fuller and Liddell Hart in Britain, Raoul Castex and Henri Mordacq in France, and A.A. Svechin and V.K. Triandafillov in the Soviet Union all used history to show what was typical and what was new as they framed their analyses.

This is not to deny that the use of history in these ways was not challenged, even before 1914. Mahan and Corbett-although better known today than their rivals (and that itself makes the point)—were locked in deep debate with a materialist school that pointed to the dramatic change in sea warfare effected by steam and armour. From the mid-19th century, history's primacy was under challenge because technological innovation presented war with perpetual innovation from the ground up. This was why so many of the strategic thinkers who followed Jomini and Clausewitz had to defend the role of history in the study of strategy, as Brodie himself was to do in 1942. In land warfare, industrialisation did more than shape battlefield tactics; through the railway, the internal combustion engine and the aircraft, it changed the core relationship in the conduct of operations: that between time and space.

Strategy as defined by Clausewitz and his generation was about the use of the battle for the purposes of the war: manoeuvre brought about battle, and exploitation used its outcome for strategic effects. The use of the nuclear weapon in 1945 elevated the impact of technology to a yet higher level, away from tactics and even from strategy in its operational setting, to its ability to change the relationship between war and policy itself. That, after all, was Brodie's fundamental insight on 7 August 1945.

In the 'golden age' of the 1950s and 1960s, history was relegated for three reasons of which the first was the most blatant and understandable. Strategy is a pragmatic business orientated towards future action. In order to do that, it begins, in its more grandiose moments, not with the present but with some point 30 or 40 years hence and then reverse-engineers back to the present, using this imagined future to shape current policy. For those who think historically, this is not unlike the use of counterfactual narratives: the 'virtual' histories that imagine events that did not 
happen or forks in the road that were not taken. So Niall Ferguson can imagine that if Britain had not entered World War I in 1914, Germany would have won the war, and the result would have been a more benign European Union than the New Order imposed by the Nazis, and one delivered sooner and at less cost than that put in place since World War II. The trouble with this sort of speculation is that once one brick in the structure is moved, another shifts. It does not follow that if Britain had not entered the war in August 1914 it would have stayed out thereafter. It could have been forced in later and on even less advantageous terms, especially if France had been overrun. ${ }^{11}$ Better to have entered the war in 1914 with a ready-made continental foothold than to have entered a year later.

Strategic thought that is solely projected on some future scenario has to be similarly selective, or is normally so, not least in its need to attract the attention of politicians whose outlooks are naturally framed by present concerns or, at best, by election cycles. In the Cold War, this single scenario focused-for understandable reasons-on an all-out nuclear exchange. The Cold War did not end in a hot war conflagration. Today's technological equivalents are cyber war or unmanned conflict, both driven by the advent of fresh technologies, but both tending to privilege the game-changing and unique features of those technologies by dismissing others and by divorcing them from war's contingent and political contexts. ${ }^{12}$ Those that do make allowance for political change are similarly monocausal in their predictions, albeit for different reasons. They do at least start from the present, but then they project forward from those trends, making insufficient allowance for contingency or shock. So today debates revolve around continuing US global dominance or its alternative: the continuation of China's rise to the point where it supplants the United States. Both are feasible, and both have current political traction and importance. But those who use them think selectively to show how they can come about. History has no obvious role in any of this.

11 Niall Ferguson (ed.), Virtual History: Alternatives and Counter-factuals, Picador, London, 1997. The argument about 1914 is made in Niall Ferguson, The Pity of War, Allen Lane, London, 1998. Richard J. Evans, in Altered Pasts: Counterfactuals in History (Little, Brown \& Company, London, 2016), attacks Ferguson's approach.

12 For example, P.W. Singer, Wired for War: The Robotics Revolution and Conflict in the 21st Century, Penguin, London, 2009. 
The second reason for history's relegation has been a direct result of the growth of university departments of politics and international relations. In the 1920s and 1930s, departments of international politics flourished on the back of World War I and the sense that it might have been avoidable. They often (as at Oxford) ousted history degrees as the choice for putative or aspirant statesmen, but they still used history as a core discipline; today they do not. Theory dominates in most, and often theory so abstract that at times its proliferation can seem to be in inverse ratio to its capacity to contribute to public policy.

For the historically trained, this puts the cart before the horse. History can be the basis for theory, not least in relation to war and strategy, as Clausewitz above all demonstrated. But now theory is dominant to the extent that history is either regarded as a quaint form of storytelling, or-when used-becomes self-selecting to prove the theory. For much political thought, history appears as a single and particular case study and is treated as though that is adequate to sustain a more general and universal argument. It is also frequently presented in forms that are unrecognisable to historians, relying solely on secondary sources and often on ones that historians would regard as out of date.

The origins of World War I as used by political science present instances of such selectivity. Historians' criticisms of Fritz Fischer's interpretation of Germany's responsibility for the war's outbreak, adumbrated in the 1960s, began immediately with fierce opposition in Germany itself. Ultimatelysay, by 1990 -Fischer came out on top within his own country, but by then scholars outside Germany were using Fischer's arguments to re-examine the responsibility of other powers. What emerged was a more nuanced and complex story than that of simple German guilt. For several decades, international relations theory paid no attention to such doubters despite using World War I as an exemplar for the outbreak of major war. It took the success of Christopher Clark's book, The Sleepwalkers (2012), to popularise such approaches and for any modification to occur. Even then the challenge of dispensing with well-embedded theory could prove greater than that of coming to terms with history itself. ${ }^{13}$

13 See, for example, Richard Rosecrance and Steven E. Miller (eds), The Next Great War? The Roots of World War I and the Risk of US-China Conflict, MIT Press, Cambridge, MA, 2015. 
Totally unaffected by recent thinking has been the role accorded to general staffs and military thought in the war's outbreak. Most historians today-and both Clark's and Margaret MacMillan's books are cases in point-pay much less attention to their part in the war's immediate origins as opposed to its conduct in the opening weeks. ${ }^{14}$ The reverence accorded to an important book in its day (and important for historians as well as for political scientists), Jack Snyder's Ideology of the Offensive: Military Decision-Making and the Disasters of $1914,{ }^{15}$ continues unabated in the international relations literature despite the revisionist scholarship on the subject since. A book conceived in the context of the Cold War, it fails to distinguish between the advocacy of the offensive at the tactical level and its place at the strategic or political (if any), and as a result simplifies a much more complex story. ${ }^{16}$

Third, and most insidious of all, there are those students of strategy who stress the value of history but do so in ways that misunderstand the business of history. Those who have vaunted history have too often worked on the basis of a one-sided premise: that its use is to explain continuity. Lawrence Freedman begins his history of strategy with the proposition 'that there are elemental features of human strategy that are common across time and space'. ${ }^{17}$ Colin Gray has been particularly vociferous on this point: 'There is an essential unity to all strategic experience in all periods of history because nothing vital to the nature and function of war and strategy changes ${ }^{18}{ }^{18} \mathrm{He}$ is not alone among professors of Reading University. Another, Beatrice Heuser, begins her history of the evolution of strategy with a section on the ancient and early modern worlds called 'long-term constants', even if she concedes in her conclusion that 'the broad picture that emerges is one of fluctuations, not constants'. ${ }^{19}$

14 Christopher Clark, The Sleepwalkers: How Europe Went to War in 1914, Allen Lane, London, 2012; Margaret MacMillan, The War that Ended Peace: How Europe Abandoned Peace for the First World War, Profile, London, 2013.

15 Jack Snyder, The Ideology of the Offensive: Military Decision Making and the Disasters of 1914, Ithaca, New York, Cornell University Press, 1984.

16 For example, Dimitry Queloz, De la manoeuvre napoléonienne à l'offensive à outrance: La tactique générale de l'armée française 1871-1914, Economica, Paris, 2009; Terence Zuber, Inventing the Schlieffen Plan: German War Planning 1871-1914, Oxford University Press, Oxford, 2002; and for the debate that Zuber generated, not least in War in History, see Hans Ehlert, Michael Epkenhans and Gerhard Gross, Der Schlieffenplan: Analysen und Dokumente, Schöningh, Paderborn, 2006.

17 Lawrence Freedman, Strategy: A History, Oxford University Press, Oxford, 2013, p. 3.

18 Colin Gray, Modern Strategy, Oxford University Press, Oxford, 1999, p. 1 (emphasis in the original).

19 Beatrice Heuser, The Evolution of Strategy: Thinking War from Antiquity to the Present, Cambridge University Press, Cambridge, 2010, p. 504. 
A pioneering case study in this approach was Edward Luttwak's Grand Strategy of the Roman Empire (1976). At the time, Luttwak was director of the Center for Foreign Policy Research at Johns Hopkins University and a consultant to the US Secretary of Defense. The book, very largely based on secondary sources, advanced the argument that Rome held its empire through what he called 'defensive imperialism'. This concept had current application in a United States recovering from the Vietnam War. 'We, like the Romans, face the prospect not of decisive conflict, but of a permanent state of war, albeit it limited', Luttwak wrote in his introduction. He went on: 'Above all, the nature of modern weapons requires that we avoid their use while nevertheless striving to exploit their full diplomatic potential.' He found similar attributes in the Romans, who possessed, 'whether by intellect or traditional institutions, an understanding of all the principles of deterrence'. ${ }^{20}$ In 1976, this made little sense to ancient historians, although today, in an example of a reverse flow, they are more accommodating of the incursion of what were effectively 20th-century ideas into the conceptual framework of the Roman empire. A similar point might be made of Christopher Clark, who also admitted the influence of international relations theory in The Sleepwalkers. In 2009, Luttwak followed his book on Rome with The Grand Strategy of the Byzantine Empire, which was less focused on its contemporary resonances and more circumspect in its claims for its implicit assumption: that grand strategy was a concept consciously articulated in Byzantium.

Even more revealing is the love affair between contemporary strategic studies and Thucydides' History of the Peloponnesian War. The use of classical authors in the study of war has a distinguished pedigree. Machiavelli took the Roman republic (not the empire) as a departure point, and it is his Discourses on Livy that contain the bulk of his military thinking. During the Enlightenment, the bedrock of professional military education was provided by the classics, including especially Caesar, Polybius and Xenophon. ${ }^{21}$ Thucydides was there but not in the front rank, although that might have been because the focus was on tactics, on the debate between the line and the column, rather than on strategy. ${ }^{22}$

20 Edward Luttwak, The Grand Strategy of the Roman Empire, Johns Hopkins University Press, Baltimore, 1976, pp. xii, 3.

21 Azar Gat, The Origins of Military Thought from the Enlightenment to Clausewitz, Clarendon Press, Oxford, 1989, p. 7.

22 Robert S. Quimby, The Background of Napoleonic Warfare: The Theory of Military Tactics in Eighteenth-century France, Columbia University Press, New York, 1957. 
In the 1890s, Hans Delbrück, as professor of world history at Berlin University and the founding father of academic military history, raised the level of the debate on strategy. Although the argument between him and the historians of the Prussian general staff focused on whether Frederick the Great had preferred a strategy of attrition or a strategy of annihilation, for Delbrück himself its origins were Thucydidean, as he made clear both in his preliminary essay on the subject in 1890 and in his magnum opus, Geschichte der Kriegskunst im Rahmen der politischen Geschichte (1900-04). ${ }^{23}$ In 1926, following World War I, Basil Liddell Hart wrote on Scipio Africanus both because 'the art of generalship does not age' and because Scipio was strategically 'modern': the servant of a republic who had 'to study and understand the interplay of the military, economic, and political forces, which are inseparable in strategy'. ${ }^{24}$ And after World War II, J.F.C. Fuller, who throughout his career had stressed the didactic purpose of military history for the contemporary soldier, wrote one of his last books — on the generalship of Alexander the Great in 1960—precisely because he believed that 'war is an art which, whatever be the period in question, is based on the same principles'. ${ }^{25}$

All the major US war colleges today, led by that of the US Navy, begin their study of strategy with Thucydides. The association of Athens in the Peloponnesian War with the United States of today is easy, if superficial: the latter is, as the former once was, both a naval empire and a democracy. It is wonderful that senior officers are receiving a rounded education, and that the complaints of classicists about the decline of their subject are answered by such a response. In 2006, two Greek political scientists, Athanassios G. Platias and Constantios Koliopoulos, wrote a book, Thucydides on Strategy: Athenian and Spartan Grand Strategies and Their Relevance Today, which rested on their belief that 'the writings of Thucydides and the grand strategies contained therein are as relevant today as they were in the past and there is no reason to believe that their relevance shall diminish with time'. They quote with approval the statement of Louis Halle, that:

23 Hans Delbrück, Die Strategie des Perikles erlautert durch die Strategie Friedrichs des Grossen, Reimer, Berlin, 1890. A French translation by Joël Mouric is available: La stratégie oubliée: Péricles, Fréderic le Grand, Thucydide et Cléon, Economica, Paris, 2015.

24 B.H. Liddell Hart, A Greater than Napoleon: Scipio Africanus, Blackwood, Edinburgh, 1926, pp. vii-viii.

25 J.F.C. Fuller, The Generalship of Alexander the Great, Rutgers University Press, New Brunswick, 1960, p. 306. 
Thucydides, as he himself anticipated, wrote not only the history of the Peloponnesian War. He wrote the history of the Napoleonian [sic] Wars, World War I, World War II, and the Cold War. ${ }^{26}$

This sort of hyperbole is catching. Williamson Murray, a military historian primarily of the 20th century whose career has embraced a deep commitment to professional military education, has studded his recent history of the American Civil War with Thucydidean references, describing their author as 'that greatest of all strategic and military historians' ${ }^{27}$ In an essay on the value of studying the past, he used what he acknowledged to be an anachronism, describing Thucydides as the Clausewitzian historian'. ${ }^{28}$

As with the Luttwak example, reverse-engineering is also going on here as paid-up historians reflect on to the past the thoughts planted by modern strategic thinkers. A great ancient historian, Donald Kagan of Yale, has deployed his expertise on the Peloponnesian War for contemporary and trans-historical effect, especially in On the Origins of War and the Preservation of Peace (1995). Kagan contributed the chapter on Thucydides to Makers of Ancient Strategy (2010), edited by another ancient historian, Victor Davis Hanson. Compiled in deliberate emulation of Earle's Makers of Modern Strategy and its 1986 successor edited by Peter Paret, Hanson's introduction to the book makes clear that his aim is to stress continuity and the enduring relevance of classical thought to strategy.

Many (probably most) of those who use Thucydides as a way into current strategy read the English translation by Richard Crawley. The Landmark Thucydides, ${ }^{29}$ the text most used in the war colleges and edited by Robert Strassler, still uses the Crawley translation. First published in 1876, it is couched in the language of the late 19th century, when the use of the word 'strategy' had become current. That had not been true, either a century earlier in English or in Greek in the 5th century BC. The standard Greek dictionary, that by Liddell and Scott, dates the first use of the abstract

26 Athanassios G. Platias and Constantios Koliopoulos, Thucydides on Strategy: Athenian and Spartan Grand Strategies and Their Relevance Today, Eurasia, Athens, 2006, p. 12.

27 Williamson Murray and Wayne Wet-siang Hsieh, A Savage War: A Military History of the Civil War, Princeton University Press, Princeton, 2016, p. 3, and see p. 1 for the point about an underlying continuity.

28 Williamson Murray, War, Strategy and Military Effectiveness, Cambridge University Press, Cambridge, 2011, p. 52.

29 Thucydides, The Landmark Thucydides: A Comprehensive Guide to the Peloponnesian War, ed. Robert B. Strassler with introduction by Victor David Hanson, New York, Simon \& Schuster, 1998. 
noun for generalship, $\sigma \tau \rho \alpha \tau \gamma / \alpha$, to the 6th century $\mathrm{AD}$, a millennium and more later. This begs the question of whether Thucydides had a concept of strategy at all and, if he did, what he thought it meant. Clausewitz defined strategy as the use of the battle for the purposes of the war, a definition too narrow and operational for those who would use Thucydides to elucidate 'grand strategy'. ${ }^{30}$

Ironically, therefore, if we follow the proponents of continuity, what we would now see as a dated and overly restrictive view of strategy as used in the early 19th century, that of Clausewitz, could be of more recent coinage than understandings of grand strategy, whose origins the above authors implicitly attribute to the ancient world. However, it required the impact of World War I to give currency to the concept and to the phrase 'grand strategy' in the modern world, and the experience of World War II and the Cold War to embed it. Are we in danger of reading into Thucydides an idea he did not have, or should we use his vocabulary rather than ours, the better to capture his concerns? In trying to understand our own times, are we wilfully misinterpreting his? Even if we are not, will we not deepen our understanding of the use of military power if we refuse to gloss over etymological and conceptual distinctions and differences, which might be awkward and complicated, but which could serve to deepen our understanding? Paul Rahe, in an essay on Thucydides as educator, eschews any reference to strategy or grand strategy but concludeswhen addressing his current relevance-that 'there is no substitute for what Thucydides instils: the capacity to reflect, to deliberate, and, more generally, to think'. ${ }^{31}$

None of these observations is designed to contradict the case for continuity in itself or to deny the value of engaging with history the better to understand present predicaments, but continuity is only half the historian's task, and the easier half. The other half is to understand change; in other words, to grapple with contingency and shock, those very phenomena against whose comprehension the stress on continuity in strategic thought militates.

30 Clausewitz, On War, p. 128.

31 In Williamson Murray and Richard Hart Sinnreich (eds), The Past as Prologue: The Importance of History to the Military Profession, Cambridge University Press, Cambridge, 2006, pp. 95-110. Rahe has used the phrase 'grand strategy' himself in the title of his book, The Grand Strategy of Classical Sparta: The Persian Challenge (Yale University Press, New Haven, 2015), but without any attempt to explain or justify the term. 
Marc Bloch, the great French economic and social historian and co-founder of the Annales school, was also a soldier who fought in two world wars, both in the successful defence of France in 1914 and in its humiliating defeat in 1940. In 1942, Bloch, a Jew from Alsace, joined the Resistance and was captured and executed by the Gestapo in 1944 . He left behind his explanation for this turn-around in France's military fortunes, L'étrange défaite: Témoinage écrit en 1940, posthumously published in 1946. Focusing his attention on the army in which he had twice served, Bloch accepted that the Ecole de Guerre had to use military history to teach what he called the 'military art'. But Bloch knew, as all professional historians know, that history does not repeat itself, and that to defend its study on those grounds is both superficial and stupid: 'It [history] knows and it teaches that it is impossible to find two events that are ever exactly alike, because the conditions from which they spring are never exactly alike.' Bloch, like the strategic thinkers referred to above, was deeply interested in the longue durée of history; indeed, it was his calling card.

But the lesson it teaches is not that what happened yesterday will necessarily happen tomorrow, or that the past will go on repeating itself. By examining how and why yesterday differed from the day before, it can reach conclusions which will enable it to foresee how tomorrow will differ from yesterday. ${ }^{32}$

During the 'golden age' the stress on theory, perhaps precisely because it disregarded history, had the effect of de-emphasising change, of privileging the present as though it was the future. As the Cold War lengthened, deepened and stabilised, it became dangerously radical to suggest that its foundations might shift, and when they did many strategists were keener to embed the past than to embrace the new. Even in the late 2010s, new circumstances prompted by the behaviour of Putin's Russia were put into old bottles as a 'second' Cold War. Commentators are fond of quoting the opening line of The Go-Between, L.P. Hartley's novel set in rural England before 1914 and published in 1953: 'The past is a foreign country: they do things differently there.' But they rarely act on Hartley's observation. The outbreak of World War I represented profound change for Hartley. That is why historians still feel the urge to account for it and why they also cluster around the other great divisions in historical narratives: 1789,

32 Marc Bloch, Strange Defeat: A Statement of Evidence Written in 1940, W.W. Norton, New York, 1999, pp. 117-18. 
1917, 1933, 1989. They might end up explaining even dramatic change by reference to continuity, but they are still grappling with what Bloch called difference.

Strategists in the 'golden age' faced a particular challenge because Brodie was - broadly speaking — proved right: strategic studies were no longer focused on the waging of war but on its avoidance. War has an enormous capacity to effect change, including revolution; by contrast, peaceand especially the peace after 1945 , which was characterised as liberal, democratic and capitalist - sanctifies stability and order. Strategy came to be about the avoidance of threat and risk, not about their exploitation. Strategic thought's neglect of war itself meant that those who had to address its conduct, the armed forces, turned to the operational level of war to do so. In the 1980s and 1990s, doctrine became the vehicle for lessons drawn from history, some of them almost contemporary, such as the 1973 Yom Kippur War, but most derived from the 'last' great war, that of 1939-45. Partly because Germany was now an ally, partly because the putative enemy - the Soviet Union-had been Germany's actual enemy, and partly because the potential theatre of war remained a European one, North Atlantic Treaty Organization (NATO) doctrines at the operational level focused on the Wehrmacht of 1939-41. This trend ignored the fact that although the German army had proved extraordinarily successful in individual campaigns, it had lost the war. Staff colleges revived the post1945 memoirs of generals who had an axe to grind, like Heinz Guderian, Hans von Luck, Erich von Manstein and Friedrich von Mellenthin, just at the point when scholars in Germany were exploring the role of the German army in the atrocities that those same officers had attributed to the regime. The writings of Basil Liddell Hart, discredited in part precisely because he manipulated those same generals in order to revive his career, found fresh readers. ${ }^{33}$ And operational thought constructed a link between pre-war German military thought and initial success in 1939-40 in a figment of the historical imagination called Blitzkrieg. ${ }^{34}$

If the Wehrmacht ever planned a Blitzkrieg campaign, it was Operation Barbarossa, the invasion of the Soviet Union in 1941. Based on hope and hubris, as well as strategic incoherence at the institutional level (between Oberkommando des Heeres (OKH), Oberkommando der Wehrmacht

33 John J. Mearsheimer, Liddell Hart and the Weight of History (Brassey's, London, 1988), stated the case for the prosecution most explicitly.

34 Standard works here are James S. Corum, The Roots of Blitzkrieg: Hans von Seeckt and German Military Reform, Kansas University Press, Lawrence, 1992; Robert M. Citino, The Path to Blitzkrieg: Doctrine and Training in the German Army, 1920-39, Lynne Rienner, Boulder, 1999. 
(OKW) and Hitler himself), it failed. Instead, military thought looked to the fall of France in 1940, neglecting the facts that Germany's success was improvised and that the campaign's outcome was as much of a surprise to the victors as it was to Frenchmen like Bloch. ${ }^{35}$ Thus, 'manoeuvre warfare', the central pillar of operational thought in the 1980s, established its own historical pedigree—its own continuity. ${ }^{36}$

Operational thought used history in the same way as strategic thought did: as a source for arguing about continuity more than about addressing the problems of change. The effects survived the end of the Cold War. From the 1990s, actual war (as opposed to deterrence) forced its way back up the agenda. One effect by the early 2000s was to expose how impoverished strategic thought had become and how inadequately it had failed to adapt to post-Cold War circumstances. Operational thought remained the prism through which actual war was addressed, and those who did so to best effect did not vaunt the revolutionary effects of technological change but stressed continuity. When General James Mattis dismissed so-called effects-based warfare in 2008 , he called for a 'return to time-honored principles and terminology that our forces have tested in the crucible of battle and that are well grounded in the theory and nature of war'. ${ }^{37}$ A year later, in 2009, General Vincent Desportes expressed similar frustrations:

For centuries we have had the feeling that we are fighting new wars, unrelated to previous conflicts, [but] with the benefit of hindsight it is surprising to see the stability of the general characteristic of conflicts, their unchanging logic and the error that could have been avoided if the 'trendsetters' of the period had simply had longer memories. ${ }^{38}$

So history returned to strategic thought through the operational level of war. The rediscovery of counter-insurgency warfare provided its principal engine. France, prompted partly by Desportes, rediscovered the colonial legacy of Gallieni and Lyautey and read the work of another Frenchman,

35 Follow the sequence of orders in Hans-Adolf Jacobsen (ed.), Dokumente zum Westfeldzug, Musterschmidt, Göttingen, 1966. The book that makes these points most forcefully is Karl-Heinz Frieser, Blitzkrieg-Legende: Der Westfeldzug 1940, Oldenbourg, Munich, 1996.

36 Richard D. Hooker (ed.), Maneuver Warfare: An Anthology (Presidio Press, Novato, 1993), provides examples.

37 James Mattis, 'US JFCOM's guidance for effects-based operations', Parameters 38, no. 3, 2008, p. 18, www.dtic.mil/get-tr-doc/pdf?AD=ADA490619 (retrieved 1 February 2018).

38 Vincent Desportes, Tomorrow's War: The Art of War in the Modern World, Economica, Paris, 2007 (English edition, 2009), p. 115. 
David Galula, published in English in 1963-64, but not translated into his native language until 2008. ${ }^{39}$ In 2006, the US Army Field Manual 3-24 on counter-insurgency cited Galula and drew on the examples of the French in Algeria and the British in Malaya to make its points. In seeking principles, counter-insurgency stressed continuity, and it did so in ways that could prove doubly counter-productive.

First operational thought, like Clausewitz's definition of strategy, links back to tactics: it sees strategy as lying within war more than as a link to policy. So it resurrects an older body of thought about strategy without making that reversion obvious. Over the decade from about 2005, operational thought in the shape of counter-insurgency doctrine became a substitute for it, although it was not strategy in the sense used in the 'golden age'. The stress on continuity impeded the need to recognise change at the economic, social and political levels. A body of military thought that had been developed in the era of empires, whether to aid conquest or to facilitate withdrawal, was not necessarily suitable to coalition interventions in others' sovereign territories unless it was subject to major adaptation driven by fresh strategic — not operational — thought.

This difference-both in Bloch's sense of change over time and between operations and strategy-produced a major divergence in practice. Operational success failed to deliver good strategy or recognisable political success in Iraq, Afghanistan or Libya. Generals reported constant 'progress' and used the metrics of towns secured or insurgents killed to prove it. They railed at politicians who would not give them the tools to finish the job, and the politicians increasingly lost faith in their soldiers. The consequence was strategic failure and a reluctance to see war as having political utility even when faced with a humanitarian disaster in Syria or when confronted with unfinished wars in Iraq or Afghanistan. The ends of these conflicts were defined as 'exits', not as victories, and the latter word was effectively driven from military vocabulary.

The point here is the need for a much more creative engagement with the past, to recognise that the function of history in strategic studies is to encourage understanding, not to stress continuity or to show that

39 David Galula, Pacification in Algeria, 1956-1958, Santa Monica, California, RAND, 1963; David Galula, Counterinsurgency Warfare: Theory and Practice, Westport, Connecticut, Praeger Security International, 1964. 
history repeats itself (which it does not). This chapter has already quoted Paul Rahe to make that point in relation to Thucydides, so let it end by reverting to Clausewitz.

On War, especially in the translation by Michael Howard and Peter Paret, gained purchase in the later Cold War precisely because it was rendered in fluent contemporary English with military terminology that possessed contemporary resonance. It spoke of 'operations' and 'total war' when the German did not, and many read and valued it for those very reasons. But the success of the Howard and Paret translation in the 1980s rebounded after the end of the Cold War, when the 'golden age' of strategic studies waned. Clausewitz was attacked in the early 1990s not least because those efforts to make him relevant in 1976 looked dated two decades later. It required a return to the historical Clausewitz to liberate him from Cold War captivity and war college dogma. The result has been a more subtle and differentiated reading that is both located in Clausewitz's own times and-ironically-more flexible in relation to his current applicability. On War achieves this for two reasons, both of which have the capacity to frustrate the very students of strategy who profess the value they derive from both Clausewitz and history.

First, Clausewitz uses history to show differences and contradictions, to show that what is generally true in war is not universally so. He explains that, because war is a reciprocal business that rests on a clash of wills, a strategic plan is not the same as strategy. A plan does not, as Moltke the Elder pointed out, survive the first contact with the enemy. In other words, strategy must adapt and change. ${ }^{40}$

Second, Clausewitz says almost nothing about the future and so offers no hostages to fortune. Instead of trying to link the present to what might happen through speculations on coming technologies or generalisations about the pace of change, $\mathrm{On}$ War remains firmly preoccupied with the relationship between the present and the past. It is engaged in a constant debate at the theoretical level, but the debate is secured by more certain foundations than studies of strategy, which address the relationship between the present and the future. The latter immediately inject disproportionate uncertainty into the equation, thereby expanding theory beyond the bounds of what it can deliver. Of course, the study of history also carries a risk: that we shall be captured by the past, not liberated by it.

40 von Moltke, Helmuth, Kriegsgeschichtliche Einzelschriften, Grosser Generalstab, Prussian Armee, 1880 . 
NEW DIRECTIONS IN STRATEGIC THINKING 2.0

It was precisely because of that danger, that of imprisonment in our own myths, that in the 1820s Clausewitz repeatedly turned back from theory to history the better to test his own hypotheses. 


\title{
13
}

\section{An Asian school of strategic studies?}

\author{
Amitav Acharya
}

I have been asked to comment on the topic: 'An Asian school of strategic studies?' I understand this question as asking whether there can be a school in Asia that represents or reflects a distinctive approach to strategic studies like the English school on international relations theory or the Copenhagen school on security studies. I am glad that there is a question mark with the topic, because one could have some serious doubts about such an idea. Posing the question is very useful for provoking a discussion about some of the big challenges and questions that confront the development of strategic studies in Asia or the Asia-Pacific to which the Strategic \& Defence Studies Centre (SDSC) has made a very significant contribution. Let me raise five supporting questions and challenges; the first three are familiar and perhaps not really critical. I mention them briefly. The last two are really crucial.

First, which region? What or where is Asia? We all know that Asia is not a given or fixed concept but one rather malleable as befits an area of multiple contested histories and, more importantly, of immense physical, cultural and political diversity. ${ }^{1}$ Regional naming keeps changing. New names keep popping up like a fashion statement. In the past three decades, we have seen an institutional naming shift from 'Asia Pacific' to 'East Asia'

1 Amitav Acharya, 'The idea of Asia', Asia Policy, no. 9, 2010, pp. 2-39. 
as evident in the shift from Asia-Pacific Economic Cooperation (APEC) in 1989 to East Asia Summit in 2005. We have seen the emergence of 'Indo-Pacific' in the past few years, although there is no institution as yet to celebrate it nor agreement on its merit. ${ }^{2}$ Regional naming is itself a very political affair as it decides which country or subregion is included or excluded and what kind of security issues become the organising theme for a school of strategic studies. It also begs the question: who is to name the region? In the past, region-naming has been done mostly by great powers. British hegemony is associated with the term 'Far East' while the United States is associated with 'the Pacific' or the 'Pacific Rim'. Who has the power to rename it now? Perhaps China, which is reviving the Sinocentric idea of the Silk Road as part of its One Belt, One Road (OBOR) initiative. But this is not going to be acceptable to Asia's other leading powers, notably India and Japan.

Second, strategic studies or security studies? There has been much redefinition of the concept of security since the end of the Cold War. Strategic studies is mainly concerned with the use and threat of use of military force. Security studies is much broader and embraces nontraditional security and human security. While strategic studies is criticised for being too narrow, security studies is often accused of becoming too broad to have coherence or utility. Lately, there has been a good deal of talk about the 'return of geopolitics'. In a 1991 essay, Stephen Walt spoke of a 'renaissance' of 'security studies'. ${ }^{3}$ Might there now be a similar renaissance of strategic studies, especially after the election of Trump and his threat to start a new nuclear arms race? Surely military threats have not disappeared. Yet security is in the eyes of the beholder, and the idea of comprehensive security has roots too deep in Asia to be sidelined in favour of military strategic studies.

Third, who is to lead or anchor an Asian school? Where might the intellectual leadership and institutional anchoring of an Asian school come from? Can Australia and The Australian National University's SDSC provide such leadership now? For some time, it has been the premier institution providing de facto leadership in the academic

2 For contrasting views on the utility of the Indo-Pacific as a concept, see Rory Medcalf, 'The IndoPacific: What's in a name?', American Interest 9, no. 2, 2013; and Andrew Phillips, From Hollywood to Bollywood? Australia's Indo/Pacific Future in a Contested Asia, Australian Strategic Policy Institute, Canberra, 12 October 2013.

3 Stephen M. Walt, 'The renaissance of security studies', International Studies Quarterly, no. 2, 1991, pp. 211-39. 
training for strategic studies in the Asia-Pacific region. But to do so overtly now might be controversial politically and impede much-needed indigenisation — or the need for more local Asian voices and scholarship. But are institutions and scholars from the region up to the task? What about universities or think tanks in Japan? China? India? South-East Asia? Singapore? Each is problematic, although for different reasons, ranging from lack of resources to lack of academic freedom.

It is revealing that some of the best strategic/security studies experts from Asia do not live and work in Asia but in the United States, Europe and here in Australia. Sometimes this is not from choice or for lack of resources but because of a lack of hospitable academic environments and academic freedom in Asian countries.

Although the above three questions are important, addressing them depends on how one deals with the last two questions. One is an intellectual question. The other political.

First, a school needs a core thematic focus and a set of generalisable concepts and methods. It is the idea of a society of states and a whole range of concepts built around it for the English school. For the Copenhagen school, it is the idea of securitisation and desecuritisation.

What could be a comparable focus for an Asian school? Could it be culture or strategic culture? I am reminded of Desmond Ball's seminal article, 'Strategic culture in the Asia-Pacific region'. ${ }^{4}$ It identified distinctive aspects of strategic culture in Asia, some of which are:

- an Asian way of war, with less emphasis on holding territory than other forms of military, economic and cultural hegemony

- informality of policy-making structures and processes

- consensus over majority rule

- pragmatism over idealism

- a comprehensive approach to security.

But putting culture at the heart of strategic studies brings back bad memories such as 'Asian values', the 'Asian view of human rights' or Asianstyle democracy. These ideas were criticised as being too 'relativist' and,

4 Desmond Ball, 'Strategic culture in the Asia-Pacific region', Security Studies 3, no. 1, 1993, pp. 44-74. 
even worse, as a justification for authoritarianism in such Asian countries as Singapore, Malaysia and China. At the very least, they smacked of too much reification, which could not be supported in view of Asia's political diversity.

To be sure, each country or region is distinctive. All theories and schools of international relations or strategic studies reflect a national or regional context. But they must do more. I have a simple test for any national or regional school: it must explain not just what happens in that country or region. A school must also generate ideas that can travel beyond them. It must have a general or universal applicability.

Take for example the English school or the Copenhagen school. To be sure, both can be viewed to some extent as being rooted in and reflecting the distinctive historical and political context of Europe. I suspect the former (especially its early version) might even reflect a nostalgia about Europe's lost empires and what it saw as Europe's largely benevolent contribution in creating a rule-based international society (albeit with European rules). Similarly, the Copenhagen school and its securitisation theory cannot be delinked from continental Europe's own intellectual traditions, including post-structuralism or discourse analysis.

But the concepts and methods from both the English and Copenhagen schools have a general universal applicability, however limited and contested. They have been usefully applied to East Asia and other parts of the world. What might an Asian school of strategic studies offer in this area?

Take for example the Chinese school of international relations, perhaps the most prominent of the emerging national approaches to the study of international relations and strategy in Asia today. So far, much of the Chinese school is based on the Chinese culture, worldview and foreign policy behaviour-past, present and future. Moreover, a good deal, if not all of it, seems like a legitimisation of the Chinese official foreign policy ideology such as the Tianxia ('all under heaven') and the 'peaceful rise' of China. It has yet to offer a set of concepts and approaches that can travel beyond China or its immediate East Asian regional environment and be used to study international relations in general or in other regions of the world. So it has yet to pass my aforementioned test of a valid national or regional school. 
The last but most important challenge is what we might call the 'Hedley Bull test' for the relations between academics and governments. This was contained in an essay by Bull in 1972 when he was still teaching at The Australian National University. Here Bull wrote:

The academic International Relations specialist ... should not be a servant or agent of his government ... There is a need on both sides for exchange of ideas and mutual criticism between academics and officials in the field of foreign policy and defence ... But inquiry into International Relations is a different activity from running the foreign policy of a country and necessarily clashes with it. ${ }^{5}$

Bull further held that:

International Relations specialists in universities and in governments should talk to each other but should remain themselves ... It is only if they remain themselves that academic students of International Relations are likely to have anything distinctive to contribute to the discussion of foreign policy problems. ${ }^{6}$

Bull could not have missed the fact that strategic studies everywhere had always been policy-oriented and enjoyed close proximity to governments. The distance is quite blurred in the United States, so much so that there is a veritable 'revolving door' between the world of academia and officialdom. Ironically, there has been some concern of late in the United States about an alleged academia-policy gap ${ }^{7}$ or the lack of adequate interaction between the academic and policy worlds. But as I have argued, the situation is the reverse in Asia: the relationship is too close and goes too far. ${ }^{8}$ How many scholars in Asia, especially those working in think tanks, but also many in the universities, would meet this Hedley Bull test? Not many, in my view.

I would add a corollary to the Hedley Bull test. This is called 'entrapment', a concept outlined in an essay I published in 2011 based on more than a decade of experience in developing strategic studies and international

5 Hedley Bull, 'International relations as an academic pursuit', Australian Outlook 26, no. 3, 1972, pp. 251-65.

6 Ibid.

7 Nicholas Kristof, 'Professors, we need you', New York Times, 15 February 2015.

8 Amitav Acharya, 'Narrowing the academia-policy divide in international relations', East Asia Forum, 20 May 2014, www.eastasiaforum.org/2014/05/20/narrowing-the-academia-policy-dividein-international-relations/ (retrieved 1 February 2018). 
relations in Asia. ${ }^{9}$ Entrapment occurs when scholars, after having provided intellectual input at an early stage of policy-making in a particular area, remain beholden to the choices made by officials and thereby become unwilling to or incapable of challenging officially sanctioned pathways and approaches for fear of losing their access and influence. Although that essay focused on regionalism, it is also true of security and strategy. The danger of entrapment is present universally where scholars and policymakers interact in a close and sustained manner.

This has unfortunate consequences, especially for the academic development of strategic studies and international relations. As I observed during my long association with Asian think tanks and universities, too many well-trained scholars are unable to avoid the temptations to become involved in policy work and thereby lose their academic edge. This in turn has been a major cause of the absence or underdevelopment of theoretical work, which is required for the emergence of any credible and sophisticated Asian school of international relations and strategic studies (whether at national or regional levels). Hence my argument was and remains that in Asia the academia-policy gap in strategic studies needs to be widened, not further narrowed.

Why do Asians fail the Hedley Bull test? Why does entrapment occur? To begin with, the primary stakeholders and consumers of strategic studies knowledge in Asia are governments, not the academic community or civil society. In fact, strategic studies in Asia is dominated not by universities but by think tanks that are closely tied to the governments or establishment forces (including some placed at universities deliberately to draw in academics and sometimes to control or entrap experts in strategic studies). Some examples here would be several members of the ASEAN-ISIS (Association of Southeast Asian Nations Institutes of International and Strategic Studies, a group of think tanks and institutes from each of the ASEAN countries, some but not all of which are based in universities); the Institute of Defence and Strategic Studies (IDSS) at the Nanyang Technological University, Singapore; the Institute of Defence

9 Amitav Acharya, 'Engagement or entrapment: Scholarship and policy-making in Asian regionalism', International Studies Review 13, no. 1, 2011, pp. 12-17. The author was Deputy Director and Head of Research of the Institute of Defence and Strategic Studies (IDSS) in Singapore between 2001 and 2007. IDSS became the S. Rajaratnam School of International Studies in December 2006 and remains Asia's largest university-based think tank and school in strategic studies, although its scope extends to other areas of international relations, including political economy and international relations. 
Studies and Analysis (IDSA) in India; the Korean Institute for Defence Analysis (KIDA) in South Korea; and the National Institute for Defence Studies (NIDS) in Japan. There are also numerous such thinks tanks and research institutes in China that do research on strategic studies, such as the China Institute of International Studies (CIIS), the China Institutes of Contemporary International Relations (CICIR), China Institute for International and Strategic Studies (CIISS), and the various centres and Institutes of the Chinese Academy of Social Sciences (CASS), to give but a few examples. Many of these strategic studies think tanks are extensions of defence or foreign ministries and/or directly funded by them and run by retired or seconded bureaucrats. University-based or genuinely independent research centres on strategic studies in Asia are rather few and far between. Even these are often subject to government control and manipulation, overtly or indirectly, either through funding, fear or both, especially in Asia's authoritarian countries. Some of these institutions are ranked very highly, such as in the 'Global Go To Think Tank Index' produced by the Think Tanks and Civil Societies Program (TTCSP) at the University of Pennsylvania, despite having little or no academic freedom or having a record of actively suppressing it. Apparently, academic freedom or freedom of expression is not taken into consideration in the TTCSP's rankings (or in the university league tables), which means think tanks and universities from well-resourced but highly authoritarian states can secure high ranking and thus legitimise themselves. ${ }^{10}$

As noted, one consequence of government or stakeholder interference is the discouragement of high-quality theoretical or conceptual work. Many policy-makers in Asia see conceptual/theoretical work or academic training in international relations and strategic studies as irrelevant or a waste of time for foreign policy-making. Yet such work is crucially needed for broadening policy choices and developing alternative ideas without which strategic studies would be impoverished.

10 In the 2015 'Global Go To Think Tank Index', the China Institutes of Contemporary International Relations (CICIR), a think tank directly under China's State Council, was placed at number 6 in the 'Top Foreign Policy and International Affairs Think Tanks' category ahead of the Woodrow Wilson International Center for Scholars (United States) and International Institute for Strategic Studies (IISS; United Kingdom), while the China Institute of International Studies (CIIS) was at 28. James G. McGann, 2015 Global Go To Think Tank Index Report, University of Pennsylvania Think Tanks and Civil Societies Program, 9 February 2016 (see p. 87), repository.upenn.edu/cgi/ viewcontent.cgi?article=10098context=think_tanks (retrieved 1 February 2018). The Chinese Academy of Social Sciences (CASS) was named the top think tank in Asia by Foreign Policy magazine for 2009. 'The Think Tank Index', Foreign Policy, undated, web.archive.org/web/20090119095446/ http://www.foreignpolicy.com/story/cms.php?story_id=4598\&page=3 (retrieved 1 February 2018). 
In Asia, a key function of strategic studies think tanks is to engage in Track-II activities, in which academics and policy-makers in their private capacity exchange ideas and develop policy directions. As Professor Stuart Harris from The Australian National University wrote in 1994, TrackII dialogues in Asia are dependent 'upon the consent, endorsement and commitment, often including financial commitment, of governments'. ${ }^{11}$ One might add to this the frequent presence and dominance of governmentlinked scholars or retired government officials in such dialogues. While they are supposed to speak in their private capacity, most often they end up presenting their government's line. At the same time, non-conforming social movements and independent academics are general excluded from Track-II dialogues in Asia.

Another problem is the influence of generalists in Track-II strategic dialogues, those who lack expertise in specific issue areas such as maritime or environmental protection. And there is much generational gatekeeping in these dialogues or the failure to bring in new faces or new blood. The result is that Track-II dialogues in Asia are unable to rise above national interests and present alternative understandings of strategy and foreign policy. They are unable to call for fundamental reforms and transformation in the region by overcoming the trap of nationalism, state sovereignty and non-intervention.

What is to be done, if anything? Instead of an Asian school, I would call for more networking-especially among universities and think tanks in Asia, the Asia Pacific, Indo-Pacific or wherever-with a view to exchanging ideas, information and solutions to common problems. This can be done at multiple levels. Track-II can be one of them. It is here to stay. But clearly there cannot be a credible Asian school of strategic studies that relies primarily on policy think tanks. Other initiatives are needed. One such initiative can be among students, like Evelyn Goh's graduate network.

11 Stuart Harris, 'Policy networks and economic cooperation in the Asia Pacific', Pacific Review 7, no. 4, 1994, p. 390. 
A fitting model is the now defunct Canadian Consortium for Asia-Pacific Security (CANCAPS), which emerged in the 1990s. ${ }^{12}$ Although funded by Canada's Department of Foreign Affairs and International Trade, renamed now as Global Affairs Canada, it was led and managed by academics. The venues of its conventions changed across Canada. Participation was open to all and mainly consisted of academics. But government officials participated in droves and with enthusiasm but without any effort to control the flow of opinion. It functioned more as a professional association for scholars and policy-makers interested in security issues in the Asia-Pacific.

In developing any strategic or security studies network, it is important to develop some core themes, especially non-traditional security (NTS). NTS could bridge the gap between traditional strategic studies and a more expansive notion of security studies. Another key area would be negotiations and conflict resolution, which have not been developed well in Asian universities and think tanks.

It is crucial for strategic studies scholars to engage in historical and theoretical research, not just policy research. To quote Hedley Bull again:

The test for an academic contribution to International Relations is that it should have either historical or theoretical depth. Academic work which consists simply of the retailing of information about international affairs, or of ad hoc comment of policy polemic, does not meet the test. ${ }^{13}$

Again this is lacking in Asia, where policy-makers distrust or disparage theoretical work and academics working within different incentive structures find no benefit from it.

Finally, strategic studies institutions and scholars should engage in genuine policy debates and explore alternative ways of promoting security. The role of strategic studies in many, if not all, think tanks in Asia is limited largely to providing background information to policy-makers rather than debating and advocating different policy positions or publicly contesting government positions. This should change if strategic studies is to have a modicum of credibility, even as a mainly policy-oriented enterprise.

12 The author served as one of the directors of CANCAPS. For an example of its work, see Marius Grinius, 'Canada and Asia: Prosperity and security', Canadian Global Affairs Institute, policy paper, June 2015, d3n8a8pro7vhmx.cloudfront.net/cdfai/pages/569/attachments/original/ 1436386569/Canada-Asia_Prosperity-Security.pdf?1436386569 (retrieved 1 February 2018).

13 Bull, 'International relations as an academic pursuit', p. 264. 
To sum up, the development of strategic studies in Asia must add independent and critical perspectives. This would require rising above national positions and perspectives in Track-II dialogues and debates. It would also require the emergence of genuine epistemic communities in functional areas organised around knowledge rather than official connection, and greater sensitivity to dissent and alternative voices from social movements. It demands nurturing and co-opting new generations of scholars. There is also a need for scholarly associations of Asian academics who study regionalism and are independent of government sponsorship. What the region needs is a free flow of policy ideas and agenda-setting for truly transformative cooperation.

Notwithstanding my reservations about an Asian school, let me conclude by stating what I consider to be the exemplary combination of academic rigour, scholarly independence and policy relevance that can serve as the inspiration for Asian security studies experts and scholars, and even a school, should there be an effort in that direction. One needs to look no further than the work of Desmond Ball, who passed away shortly after the SDSC 50th anniversary conference. Des Ball's work was scholarly at the highest level, especially his contributions first to nuclear strategy, then to Asia-Pacific regional security. It is also striking that his early and pioneering work on national security and nuclear strategy, especially on the US military bases on Australian soil, was extremely critical of the US and Australian government policies. Indeed, it was a bible for a generation of peace activists in Australia, as I knew personally when I was a student in Perth in the 1980s. This suggests his integrity and independence. As the Cold War ended, Des Ball's work shifted to Asia-Pacific regional security issues. This corpus of work provided an invaluable contribution to the thinking and approach of governments and of the policy community of the region as they embarked on initiatives to build new regional cooperative security institutions, such as the ASEAN Regional Forum. ${ }^{14}$ Despite this, Des Ball continued to assert his independence, challenging and embarrassing governments that he saw as perpetrating oppression (as in Myanmar and Indonesia) or failing to offer public transparency and accountability, as seen with the revelations about

14 I was fortunate to be a collaborator in Des Ball's work on Asia-Pacific multilateralism, especially that on preventive diplomacy. See Desmond Ball and Amitav Acharya (eds), The Next Stage: Preventive Diplomacy and Security Cooperation in the Asia-Pacific Region, Strategic \& Defence Studies Centre, The Australian National University, Canberra, 1999. 
US military bases in Australia and later (in 2001) Singapore's alleged intelligence operations in Australia. ${ }^{15}$ If Asian scholars can achieve this sort of intellectual courage and integrity against the backdrop of engaging in outstanding scholarship, I will withdraw my reservations on an Asian school of strategic (or security) studies.

15 Catherine McGrath, 'Claims of Singaporean spying', $A M$, 9 August 2001, www.abc.net.au/am/ stories/s343479.htm. 



\title{
14 \\ The future of strategic studies: The next golden age
}

\author{
Robert O'Neill
}

It was stimulating to receive the organisers' challenge to discuss the future of strategic studies rather than the past. It is so much easier to be wrong about the future than about the past-and it matters a lot if you are wrong in our profession! Think of all the bad strategic plans that have been hatched by supposedly excellent professionals, such as the Schlieffen Plan, Fall Gelb-the German General Staffs plan for the invasion of France, which was discarded by Hitler due to Manstein's persuasionand Operation Barbarossa, which was not discarded by Hitler but should have been.

Now, maybe it is better to have a bad strategic plan than no plan at all. At least it creates a framework for the design and development of armed forces and focuses the minds of those who might have to implement them on the intelligent use of the forces available to them. Personally, I doubt this-the combination of strategic plans and forces to implement them does create a temptation to use them-such as that which overcame Kim Il-Sung's judgement in 1950 in invading South Korea, or that of the Chinese in going to war against the Vietnamese in 1979, administering what Deng Xiaoping described to President Jimmy Carter as 'a slap to a naughty child'. Strategic plans, if we have them at all, need to be very well 
conceived and controlled at both political and operational levels. And this is where policy research institutes such as the Strategic \& Defence Studies Centre (SDSC) have an important national and international role to play.

I have been invited to forecast the next 'golden age' in strategic studies. This implies that there are non-golden ages in our field, even 'dark ages'. So let me say at the outset that I prefer an output of steady daylight to alternately baking under the golden rays of a midsummer sun and then freezing in wintry darkness. My remarks therefore are aimed at achieving the best performance by our strategic thinkers over most of their working lives. That approach will do more to maintain our societies and our planet intact and at peace than occasional flashes of inspiration born of a terrible time of death and destruction.

What are we aiming at?

\section{Tasks for the 21st century}

So here we are, in the late 2010 s, with many of the dangers of the 21 st century already apparent. Let me run through the most serious of them:

- the proliferation of nuclear weapons

- the development of tough, strongly motivated 'terrorist' forces

- climate change leading to a rise in sea levels and mass movements of displaced persons from low-lying areas

- acute food shortages in badly governed regions, especially in Africa and the Middle East, leading to further waves of distressed people moving into Europe

- accommodation of a more powerful and assertive China

- increasing world population coupled with inadequate quality of government at national, regional and global levels.

They are diverse-much more diverse than planners and thinkers have had to address in previous centuries. Clearly we have a lot to do, and many agencies will have to be involved in developing policies for handling these threats. Military force remains important, but inputs need to be made from most areas of government and expertise outside the realm of government, particularly those of a large university. 


\section{The security policy dialogue in Australia}

Our national record in the past for developing strategic policies has not been a distinguished one. Australia's role until 1942 was essentially that of providing auxiliary forces to Great Britain. We had sketchy plans from the early 1930s but lacked the substantial forces that they required for implementation. The Japanese attacks on Pearl Harbor and Malaya in December 1941 suddenly brought awareness that we are ultimately responsible for our own security. We needed plans plus forces. I recall a conversation in 1974 with General Rowell, who was Deputy Chief of the General Staff in 1941-42. Rowell was asked in January 1942, by a visiting American officer, what he would do if the Japanese landed a force of two divisions on our north-western coast. 'I'd run for the salvage corps,' Rowell replied. It was a flippant response, but it showed that as far as realistic defence plans and actual capabilities were concerned, our cupboard was bare.

In the early 1970s, when I was beginning to write the official history of the Korean War, ${ }^{1}$ I wondered how our plans and policies to address the needs of the Cold War were developed between 1945 and 1950. Rowell walked me through the unrecorded details of our strategic planning for the period 1946-50. The cupboard was still fairly bare, and the size and capacities of our armed forces were low-not to match our plans but to save money. For a while our regular army consisted of two battalions of infantry. Then came the Korean War, and we increased it to three battalions. A national service scheme was developed, but the period of service required was very brief. The navy acquired an aircraft carrier, and the Royal Australian Air Force was upgraded from World War II Mosquitoes to Meteors and then Sabres. We entered into a closer association with Britain in the Australian, New Zealand and Malaya (ANZAM) linkage, and of course we were part of the Australia, New Zealand, United States (ANZUS) Security Treaty, not to mention the Southeast Asia Treaty Organization (SEATO).

Defence planning and strategy rested largely in the hands of the Joint Planning Committee. They, three officers of the rank of colonel or equivalent, reported to the Defence Committee, which was composed of the three chiefs of staff and chaired by the widely feared Secretary of the

1 Robert O'Neill, Australia in the Korean War 1950-53, vol. 1: Strategy and Diplomacy, and vol. 2: Combat Operations, both Australian War Memorial and Australian Government Publishing Service, Canberra, 1981 and 1985, respectively. 
Defence Department, Frederick Shedden. It was interesting for me to trace the origins of policy initiatives from the drafts produced by a major in army headquarters, flowing on to his lieutenant colonel superior, then through the Joint Planning Committee and the Defence Committee to the Cabinet. Sometimes not a lot was changed on the way through. It must have felt good to have been one of those majors on the planning staff in those days.

An important thing to note about our first national defence planning system is that there were few, if any, external inputs. I saw no evidence that anyone inside the defence establishment took any notice of journalists, academics or even diplomats. That last element changed in the mid-1950s as Arthur Tange became Secretary of the Department of External Affairs and joined the Defence Committee as a member in his own right. Tange made contribution with characteristic vigour and cutting power. Soon, as Peter Edwards has related, Tange was complaining that Defence was using External Affairs to do its thinking as well as its own. ${ }^{2}$

Political contributions to the shaping of defence planning were largely confined to the domain of resources-by stating what could be afforded and what could not. I must make an exception here for Percy Spender, who always saw a clear strategic reason for our becoming involved in the Korean War: the gaining of a military alliance with the United States. But this idea did not emerge from his own department nor from the Defence Committee! It was his personal contribution, which not even his prime minister thought achievable when Spender first mentioned it as a war objective.

\section{The roots of the SDSC}

Gradually, in the 1960s, the generation of Australian ideas on international security and defence strategy became more open to outside influences. There were the out-and-out critics active in the universities and the newspapers. They did not achieve much influence. And there were the critics who stood on respected ground, and here I refer particularly to Tom Millar, Alan Watt, Bruce Miller and Hedley Bull. They all were given an audience by those on high in the government and in the Departments

2 Peter Edwards, Arthur Tange: Last of the Mandarins, Allen \& Unwin, Sydney, 2006, Chapter 6. 
of External Affairs and Defence. They were not given an easy ride. Because Tom and Alan had served in the army and the foreign service respectively, there were questions of ego to be faced on both sides in making the dialogue work. Hedley, who had made his reputation on the other side of the world in a field most Australians knew nothing of - arms controldid not face personal hostility, but he still had to get his message across, which was in part to stand up to the great powers, especially our allies, and in part to view nuclear weapons as a global problem that required a global solution. He exerted a useful influence in persuading key people in the Department of External (and then Foreign) Affairs to develop a positive approach to the Nuclear Non-Proliferation Treaty. Bruce's connections were stronger on the side of the Department of External Affairs than that of the Department of Defence, but he used them skilfully and built up the Third Monday Group, which flourished from the late 1960s through to around 1973, bringing together government department heads and deputy heads with relevant Australian National University specialists once a month. The growth of tensions over the Vietnam War led to this arrangement breaking down, and it ceased to function in the dying days of the McMahon Government.

During the late 1960s, the newly founded centre was taking its first tentative steps forward in offering advice, public and private, on national and international security issues. We were lucky in that Tom, Hedley and Bruce all had experience of working at and with the International Institute for Strategic Studies in London. That experience gave them several advantages: a broader approach to international security than just that of a national perspective; experience of working as academics with members of the government community, both civil and military; personal networks of expert people around the world, both in government and outside; standards in assessing ideas and writing; and knowledge of how to fund such an operation without allowing the resulting work to be skewed by the funders. All this knowledge and experience helped the Strategic \& Defence Studies Centre get off to a good start. It was an early 'golden era' both for the field internationally and here in Canberra. These elements remain very important for the Centre's future standing and the quality of its work. 


\section{Necessary ingredients for strategic studies}

Let me now review what I think are the necessary ingredients for the flourishing of strategic thought today. First are the people: expert, accomplished or promising to be so; second, a breadth of expertise from the military field through social politics, economics and international relations to peace studies; third, a supportive institution such as ANU to have as a base; and fourth, national and international perspectives in its work.

\section{People to shape the dialogue}

Probably the most important element in shaping the dialogue in the future will be the quality of the people who are conducting it. And probably the most significant factor to look for and nurture here is intellectual quality, especially the ability to think outside the box and to resist being co-opted by a dialogue partner who is hierarchically organised. We have been lucky to date with our range of contributors, beginning in the 1970s with two young men in their 20s, Des Ball and Ross Babbage. Many more have come on since then, from a wider range of home institutions and agencies, including the armed services.

They do not all need to be offered a tenure track position because many of them will be needed in their own agencies where they worked before coming to the Centre. The Centre's continuing semi-permanent and permanent staff will be relatively small. They should come in at a range of points in early and mid-career to keep things on the boil and crossfertilise from different vantage points. The three-person team we had in Des Ball, Ross Babbage and Jol Langtry is a good case in point. All the staff members need to be not only very bright but also producers. They need not only to write easily but also to be good conference and discussion group members. They not only need to make their own contribution but also allow others to influence them. They need to know how to develop and sell an idea, but not to oversell it.

\section{Breadth of experience required}

Because the range of problems that needs to be tackled in strategic policy analysis is so broad, we need people from a variety of disciplines and work areas, not to mention both genders. I have not mentioned science and 
engineering as necessary inputs yet, because it can be very difficult to find the right people from those quarters to take part in the work of a larger team that is focused on wider objectives and composed largely of others whose backgrounds lie in political science, international relations, geography and history. Nonetheless, we have to accept the challenges and bring more technological expertise into the debate.

As someone who has been mentored by Michael Howard and Basil Liddell Hart, I cannot omit mention of the importance of history as a major area of expertise in the field of strategic studies. Hew Strachan has already made reference to this point, so I shall not labour it too heavily. However, history is important for several reasons in the making of good policies for future use. History offers a scale of known facts against which the consequences of new policies can be assessed. Knowledge of history enables clouds of illusion to be dispersed. History brings a spotlight to shine on the personal factors that can do so much to make or mar an intense, dangerous activity such as a war or a conflict. History also reveals the recurring but deceptive traps into which government leaders and force commanders can fall so easily, such as overoptimism, technological limitations and imperfections, the role of public opinion and the limitations on what both civil populations and armed forces are willing to bear. The Centre has been well served by David Horner, Joan Beaumont and many other people with historical expertise.

Strategic policy is, in the final analysis, a political business. It therefore needs the contribution of political wisdom if it is to have a sound purpose and remain within the confines of available resources. From where do we acquire political wisdom? Journalists are one obvious source. Another is rising members of parliament. A third is political staffers. These are all bright people who have to think about defence and foreign policy issues and commit themselves to opinions on them. Many of those who take part in this political discussion of security policy are very aware of the limits of their knowledge. They need help, and this can be another important contribution that the Centre can make and has done in the past. Politicians are extremely busy people with all kinds of pressures on their time and energy. Therefore any assistance offered must be well focused and address their needs without wasting any of their precious time.

It is important to balance political connections. It would be a big mistake for the Centre to gain the reputation of being the think tank of one party or another. Fortunately, there has not been a fundamental division on 
security policy issues between the major parties for quite some time, and it is possible to work with both sides without becoming compromised. Another set of opportunities lies in speaking publicly or semi-publicly at party conferences and lesser gatherings and appearing before relevant parliamentary committees.

A related group of people that the Centre needs to have a good relationship with is the public service-a huge repository of relevant knowledge and expertise, not to mention thinking and debating capacity. Without some working connection with people who work in Defence, Foreign Affairs, Prime Minister's, Treasury and some other departments of state, the external debate in research institutes might well be duplicating or even trailing behind the debate taking place within the halls of government. Not everyone in the government's employ will want to work with outsiders. There are obvious risks in such connections for both sides. But quite a lot are keen to be engaged, if properly asked, and they add a huge amount to academic capacity because they have substantial resources at their command, they know what politicians think, and they have great connections. My own early visits to Moscow and Beijing were greatly facilitated by Paul Dibb, who provided me with access to an array of his best contacts in those capitals of enigma. Later, when I was at the International Institute for Strategic Studies (IISS), I found that a high proportion of our best contributions in debate, in conferences and in advice generally came from the civil service of the United Kingdom, other European North Atlantic Treaty Organization (NATO) states, the United States and Canada.

Another important resource is the diplomatic corps in whatever capital city one happens to be working. As in dealing with the public service, care in selection of contacts is necessary, and you should not believe everything you hear. But in terms of getting the best value from dollars spent on international travel, good diplomatic contacts are one of the best aids that one could have. That means reciprocal care of them on one's home base also.

Although we were deeply involved in the Cold War in the 1970s, we were able to have a relatively friendly relationship with the staff of the Soviet Embassy. There is no doubt that at times they became bored with having to propound their official line on everything. Sometimes they might relax a little and let me see what was really on their minds, whether it was on arms control policies or on social conditions at home. There were risks in 
this semi-public relationship, of course. After one conference, which had been attended by a mid-level Soviet diplomat, Peter Samuel, a well-known journalist, published a newspaper article headlined 'The SDSC-Where ASIO meets the KGB'. Samuel had recognised a senior ASIO member in the audience as well as the Russian. That afternoon, after the paper had appeared, the Russian came urgently into my office, saying: 'Bob! Bob! I am not KGB!' I could have said: 'No, Yuri, you are GRU!' but I forbore. I was glad that the Soviet Military Intelligence Service, the GRU, thought we were sufficiently relevant to be worth keeping an eye on.

Finally, let me mention another important group that has a major contribution to make to strategic studies: the armed services. I would not have said this so confidently 40 years ago, but times have changed. The armed services themselves see much more to be gained from education, debate and post-graduate qualifications than in the 1960s when I was a member of the Australian Army. The idea of the Joint Service Staff College, with which several of us became involved in the 1970s, has blossomed into the Australian Command and Staff College, which has its own highly qualified faculty as well as a considerable body of students drawn from around the world.

Given the nature of recent major wars, from Vietnam to Afghanistan, it is very important that we know more about what is happening at the coalface. What works, and what does not? The people who are actually out there, boots on the ground, exposed to death and injury by improvised explosive devices (IEDs), mines, sniper shots and assassin groups, are best equipped to give a verdict. Then their judgements need to be picked up, brought home and considered. I applaud the work that my former doctoral students John Nagl, Carter Malkasian and Daniel Marston have done and continue to do in this regard, but we need more of them as well as from them. This kind of warfare, which is wider than 'counter-insurgency', looks as though it will be with us for a long time. We need to keep lifting the standard of our effectiveness to bring conflict under control and keep it moving towards an end that we will be happy to accept.

\section{A strong institutional base}

If the Centre is to continue to flourish, it needs a strong resource base to support its work and to give it the strength to exert an influence. In the 1970s it was not at all clear that the resource base would be adequate, but thanks to the good efforts of Des Ball and Paul Dibb as Centre heads, the 
necessary resources were found. Over the past decade, the resource base provided by the university has grown. Now under Brendan Taylor, the Centre is at a level of strength that has not been exceeded previously. The level of support offered to strategic studies has been increased with the addition of the National Security College and the sharper focus given to the work of the Coral Bell School of Asia Pacific Affairs.

Of course nothing should be taken for granted in the turbulence of university politics, but given the widely accepted importance of the subject and the many ways in which the world is getting into increasing difficulty, I am tempted to say that the resource base will be adequate provided that the Centre continues to produce good work. Having worked for several years outside the university framework, let me say that this is a great advantage. Supplementation by grant funding and contract work in teaching and supervision can be added to the mix, provided it is done without compromising the Centre's independence, both actual and perceived.

\section{National and international cooperation}

However, let us not think too much in a Canberra mode. The work of the Centre is, of its very nature, international and interdisciplinary. Fortunately, its influence is enhanced through the presence in Canberra of the Australian Strategic Policy Institute, the Australian Command and Staff College and the Australian Defence Force Academy. Then there is the wider layer of institutions that work in our field in nearly every Australian state. Here I think particularly of the Lowy Institute in Sydney, the Australian Institute of International Affairs nationwide and the Perthbased think tank Future Directions International. There is a lot of good work being done right around Australia, and thanks to the Internet it is being made available to all those who are interested and able to tunnel their way through the various websites involved. However, all this work needs to be brought together, assessed and the best of it disseminated more widely. There is a role for a national leadership team!

Looking further out across our national borders, we have a good tradition of regional cooperation with the principal research institutions of SouthEast Asia, South Asia and East Asia. They offer a vital range of inputs, and they are also a discriminating group of assessors of work done in Australia. The Centre needs to look to its reputation among this group, which embraces both first- and second-track connections. 
On the other side of the Pacific, we see the strongest national powerhouse of ideas in our field in the United States. We have strong links with US research institutes and universities. For decades we have gone there and worked our way around. Now it is good to see them come to us, as the RAND Corporation has done recently. The United States is in itself going to be a particularly interesting place to observe and analyse in the era of President Donald Trump. We know from the recent debate that a substantial slice of the American electorate is not willing to support 'free-riding' allies. Wars that result in substantial human casualties are not supported by public opinion unless the stakes are very high. The US armed services (and their personnel) remain very technologically oriented. How does this equip them for gaining the friendship and cooperation of largely pre-information technology people who are apprehensive about the consequences if they and their societies ascend the technological ladder? There are many problems of this kind and uncertainties regarding the future policies and capabilities of our major ally for us to think about.

Globally, let us not forget the capabilities and connections of the International Institute for Strategic Studies. Its size, scope and breadth of its membership are unique. It was a dominant part of my life for 20 years, and it is pleasing to see Tim Huxley of its directing staff here today. I hope the IISS and the SDSC will continue to work fruitfully together in coming decades.

\section{New conditions of the 21st century}

Moving from the mid-20th to the early 21 st century, there are several relevant differences that I should note.

First, until the British referendum of 2016, international boundaries were becoming less significant than they were in the mid-20th century. Cooperation in strategic thinking between nations, groups of nations (especially alliances) and globally has become a much more common and natural process. It is hard now to imagine millions of young men in Europe reporting to mobilisation depots on a few days' notice from their national capitals. Western powers simply could not do it, although a few non-Western states probably could. We can still blow each other to pieces with nuclear weapons, and subnational groups may be able in future to do so. We live in a very different context of public opinion from that of the early and mid-20th century. Hatred still exists between nations, but it is 
more confined than it used to be and most governments find it a problem rather than an advantage. However, conversely, international flows of refugees are strengthening the significance of national boundaries. How do we keep them effective in this sense without encouraging hostilities?

A second difference, reinforcing the power of the first, is the Internet and the huge array of devices that work through it, ranging from the personal computer and iPad to the smart phone and 'social networks'. These are major new factors with strategic relevance. They threaten the power of authoritarian and weak governments. They enable insignificant individuals and groups to become significant actors. They threaten to undermine traditional authority structures, including political parties, government departments, armed services and police. They will need to be taken into account as never before. As the use of the Internet has grown, so has the power of the hacker and the spy. I shall not go into further detail on these forms of warfare because they are already under attention by the cyber-security community. They are becoming more important as we come to rely more heavily on information technology, and we must take them more into our own thinking.

On looking forward into the coming century, it is obvious from events in Africa and the Middle East that we need to focus more closely on a third set of issues-namely, the 'quality of government'. This is one of the key elements in what we have called over the past 60 years 'counterinsurgency'. Of course counter-insurgency also requires specialised military capabilities, including the ability of counter-insurgent forces, especially when they come from afar, to relate to and become friends with the people they are trying to help. Also the counter-insurgents need in-depth knowledge of the country or region in which they are operating.

Fourth, we can expect to see less of major conventional warfare than in the era of the world wars, but I do not expect to see it disappear, except possibly among the major powers. At that level it is simply too destructive an option to take up against each other, although that does not mean that they will not ever use it. Therefore, conventional warfare will remain an important element of strategic studies.

Fifth, as the use of the seas grows in intensity, there are going to be more maritime disputes covering such issues as national sovereignty, Law of the Sea, control of refugees and access to minerals. Similarly, we can expect a growth of air-related problems as ground-launched missiles become 
more readily available, terrorists work out more ingenious ways for taking control of aircraft for their own purposes, and aircraft can be coupled with information technology to give a new dimension to espionage.

We are all aware of the increased salience of economic factors in national and international security. We will need to pay greater heed to the quality of national government economic management in states of interest to us, the effects of uneven distribution of resources within societies, the interdependence of states for access to critical materials-from foodstuffs to fuels - and the management of the huge costs of defence and security policy.

I should mention in passing the issues of the use of space for travel, communications and exploration. At present, we have a network of treaties and agreements that make it difficult for one state to threaten another from space, but those agreements can always be infringed. We are also sending off a series of probes and broadcasts designed to attract the attention of anyone 'out there'. It seems to be assumed by the scientists responsible for these missions that the creatures whose attention may be drawn to us will be pleasant and well behaved when they come to inspect us. We need to probe that question a little more deeply too!

\section{Conclusion}

While I have focused these remarks on the Strategic \& Defence Studies Centre, I think they have application to research institutes in the field of strategic studies the world over. And that is important-we have a tough set of global problems to deal with. The set of challenges that I laid out at the beginning of this chapter will have to be dealt with on a global basis rather than just a national or even a regional one. We need to assemble a widely composed team of national and international institutions to grapple with and hopefully solve them. I think Australia is ready to play a part in meeting this challenge, and doubtless others are too. Let us all get working and keep the sunlight pouring down to help us solve formidable problems. Another dark age, at the world's current level of population and resource consumption, would be very nasty indeed! 



\section{5 \\ Conclusion: What is the future of strategic studies?}

\section{Paul Dibb}

Strategic studies in Australia seems to be undergoing a period of introspection about what to focus on, with concerns about whether it is still relevant to a greatly expanded agenda of 'national security challenges'. There is the further issue of whether strategic studies should be separate from the study of international relations. Then there is the long-standing debate about whether the label 'strategic and defence studies' is a proper area for academic study, given its concern with military matters. All these issues have been touched upon-to a greater or lesser extentin these chapters, themselves based on the Strategic \& Defence Studies Centre's 50th anniversary conference in July 2016.

The purpose of this conclusion is to discuss the foregoing issues, analyse the pros and cons of particular areas of enquiry by strategic studies, and identify future priorities for research from an Australian perspective. My aim is to open up an important area of scholarly discussion about the direction of strategic studies in the second decade of the 21 st century. Let me begin, however, by reflecting on some of the earlier challenges facing strategic studies as an academic discipline and the lessons we can learn. 


\section{Strategic studies and its critics}

Concern about the appropriateness of strategic studies as an academic discipline is not new. In 1968, Hedley Bull wrote an article in the journal World Politics called 'Strategic studies and its critics', and, in 1981, Robert O'Neill wrote an SDSC paper called Strategic Studies and Political Scientists: Strategic Studies and Its Critics Revisited. ${ }^{1}$ These two papers aimed to answer the critics of strategic studies in two very different eras. Hedley Bull was writing in the midst of the Cold War about moral questions surrounding the issue of nuclear war, whereas Bob O'Neill wrote at a time when the Vietnam War-which ended in 1975-was still fresh in the minds of Australians as a highly contentious military intervention with our US ally.

Let me turn to Hedley Bull's line of reasoning and its relevance to the current debate. First, I shall address what he meant by the term 'strategic studies'. He begins by proposing that strategy in its most general sense is the art or science of shaping means so as to promote ends in any field of conflict. But he goes on to argue that in the narrow sense in which he is using it, the sense in which 'strategy' is interchangeable with 'military strategy', it is 'the art or science of exploiting military force so as to attain given objects of policy'. ${ }^{2}$ Elsewhere, he argues that 'the military balance is itself the most important source of security'. ${ }^{3}$ It should be noted that he was arguing this in the context of the central nuclear balance between the United States and the Soviet Union. My own view is that strategic studies essentially deals with the role of force in international society. However, that definition is to be interpreted broadly: it should study how military forces are used both directly and indirectly, including for coercion, deterrence and what Coral Bell would have called signalling. This use of force may be present or potential, direct or indirect, short or long term. ${ }^{4}$ I recognise that strategic studies in the current era must go well beyond such a rather

1 Hedley Bull, 'Strategic studies and its critics', World Politics, July 1968, pp. 593-605; reprinted in Hedley Bull on Arms Control, ed. Robert O'Neill and David N. Schwartz, St Martin's Press, New York, 1987, pp. 11-24; and Robert O'Neill, Strategic Studies and Political Scientists: Strategic Studies and Its Critics Revisited, SDSC Working Paper No. 40, Canberra, 29 April 1981.

2 Bull, 'Strategic studies and its critics', p. 11.

3 O'Neill, 'Arms control and the balance of power', in O'Neill and Schwartz, Hedley Bull on Arms Control, p. 55.

4 See Australian Strategic Analysis and Defence Policy Objectives, September 1976, in A History of Australian Strategic Policy Since 1945, ed. Stephan Fruehling, Defence Publishing Service, Canberra, 2009, p. 549. 
narrow definition. For example, there are issues to do with soft power for coercive ends and new challenges such as the strategic implications of climate change. There is also important interaction between military, economic, political and other factors shaping the international strategic environment.

Hedley Bull listed the distinguishing features of what was then the new style of strategic analysis as follows:

- Strategic thinking was no longer exclusively concerned with the efficient conduct of war and the preserve solely of the military.

- Strategic thinking was necessarily abstract and speculative in character because there had not yet been a nuclear war.

- A characteristic of strategic thinking at that time was its sophistication and high technical quality because the intellectual resources now being devoted to strategic studies are without precedent'. This had resulted in a literature of higher technical quality and a discussion of a higher standard of sophistication than had existed before. ${ }^{5}$

These views might seem a little strange from our present-day perspective, but it needs to be remembered that this was during the Cold War, and strategic studies had had a difficult and contentious birth. This is reflected in Hedley Bull's detailed rebuttal of the critics of the work of civilian strategists, including accusations that they leave morality out of account and are indifferent to the moral standing of the causes for which war is undertaken. His response to this was that strategists as a class are neither any less nor any more sensitive to moral considerations than are other intelligent and educated persons in the West. ${ }^{6}$ Additional accusationsand Bull's responses-included:

- Strategists 'take for granted the existence of military force and confine themselves to considering how to exploit it, thereby excluding a whole range of policies such as disarmament or non-violent resistance'. Bull's response to this was that strategists take the fact of military force as the starting point because the capacity for organised violence between states is inherent in the nature of man [sic] and his environment.

- Strategists 'are inclined to make unreal assumptions about international politics ... that simplify and distort political reality and do not allow

5 See Bull, 'Strategic studies and its critics', pp. 11-14.

6 Ibid., pp. 15-24. 
for change'. Bull acknowledged that this was a complaint with a great deal of force because the technical rigour and precision of much strategic analysis had been achieved 'at the cost of losing touch with political variety and change'.

- Civilian strategists 'are pseudo-scientific in their methods; the specialist techniques they employ-such as game theory, systems analysis, simulation and the writing of scenarios-are bogus when used to arrive at strategic decisions and serve to give an air of expertise to positions arbitrarily and subjectively arrived at'. His retort to this was to recognise the limits of rigour and precision and to be on guard against their misuse rather than abandoning rigour and precision in favour of something else. He observed, in his well-known trenchant manner, that the strategist cannot be held responsible for the use that others make of his ideas.

- The strategist 'is detached and aloof, but he has no right to be'. The strategists, 'who have the ear of the powerful, might accomplish great things if they abandon the strategic mode of reasoning for the conscientious, but instead they are collaborators in the system and are speeding up its movement toward catastrophe'. Bull replied that civilian strategists have at least charted some reasoned course where otherwise there might well have been only drift. This has provided some solid intellectual fare that subsequent generations are likely to recognise as a serious attempt to come to grips with the problem. He concluded that it was difficult to escape the conclusion that even though the civilian strategists have sometimes committed errors, 'they have served us well'.

What strikes me in all of this is just how defensive Hedley Bull had to be in justifying the legitimacy of the intellectual role of civilian strategists, particularly in the new field of arms control and the central nuclear balance. Robert O'Neill has told me that in 1968 one had to be on one's guard when writing about strategic studies because the academic culture was unsympathetic - more so in Australia than in the United Kingdom. ${ }^{7}$ Bull's intellectual challenges remind me more of the era immediately after the end of the Cold War than any challenges we might be currently experiencing. As I have recorded elsewhere, with the sudden collapse of the Soviet Union in 1991, SDSC had to adjust dramatically to an altered international strategic environment and to new subjects for strategic

7 R.J. O’Neill, personal communication (email to author), 2 September 2016. 
analysis. ${ }^{8}$ We had entered a new era with Francis Fukuyama's 'end of world history' thesis and the need to retool traditional strategic studies to our region. Those of us who had spent most of our careers focusing on the USSR and the risks of nuclear war between that country and the United States suddenly had to reinvent ourselves. The end of superpower confrontation meant that much more attention could now be paid to the question of improving regional security dialogue and developing a new security architecture. A whole new range of issues surfaced in the regional strategic agenda, including major challenges that changes in the nature of conflict presented to many nations in the development of their armed forces as well as an increased demand for high-level education on strategic and defence policy issues in an era with no clear threats.

As it so happened, Australian strategic thinkers were well prepared for the latter challenge because of pioneering work on concepts for the defence of the Australian continent and how to structure a defence force without an identifiable military threat. SDSC's research on regional security, for example, was expanded to include the effect of population movements, security problems caused by environmental concerns, the relevance of the Revolution in Military Affairs to regional countries, regional defence decision-making, the US-Japan relationship, Indonesian defence developments, China's foreign and defence policies, and developments in North Korea as well as terrorism and transnational crime. ${ }^{?}$

SDSC has adjusted quite well to the new security challenges in the post-Cold War era and established a reputation for being the leading academic authority in Australia on Asia-Pacific regional security issues. So the question facing us now is more what to do with our rapid growth and success in the last decade or so. SDSC now has 27 members of staff compared with only five in the mid-1990s, when it had almost ceased to exist, not least because of reduced Australian National University (ANU) priorities for our research on defence-related issues. Now, the challenge facing us is an ever-expanding strategic studies agenda and teaching load and determining what direction and priorities should drive us. We must not allow strategic studies to become paralysed by the endless range and scope of potential issues to study that face us.

8 Paul Dibb, 'SDSC in the nineties: A difficult transition', in A National Asset: Essays Commemorating the 40th Anniversary of the Strategic and Defence Studies Centre, ed. Meredith Thatcher and Desmond Ball, Strategic \& Defence Studies Centre, The Australian National University, Canberra, 2006, pp. 84-7.

9 Ibid., p. 86. 


\section{Whither strategic studies?}

The first question to address is whether strategic studies should be separated from international relations and such disciplines as international political economy. Hedley Bull did not believe that it was desirable to separate strategic studies from the wider study of international relations, although he said it could be argued that it compares very favourably with some other branches of political science, both in its moral and social relevance and as an intellectual discipline. ${ }^{10} \mathrm{He}$ acknowledged the emergence of strategic studies as an appropriate subject for inclusion in university curricula. And he observed the fact that strategic expertise had come 'to have a political function as an ideology is inevitable and, I believe, by no means wholly regrettable'. ${ }^{11}$ This was quite a remarkable and bold observation to make at that time. I have experienced remarks in the past that SDSC would be more appropriately located not in a university but in a defence college because of moral and ideological concerns. However, we certainly have not known the hostility that SDSC faced during the Vietnam War and the sort of baseless moral suspicions that Bob O'Neill experienced. ${ }^{12}$ Nevertheless, my view is that the nexus between strategic studies and international relations has drifted further apart since Bull's time as international relations has become more theoretical in its analysis. Strategic studies is now firmly established as a separate academic discipline, less preoccupied with theory and more practical in its application. But, needless to say, sound strategic analysis should be founded on an intellectually rigorous conceptual base. Moreover, we should continue to have a close relationship with international relations departments on international political issues. In the end, there will always be inevitable tension between ideas of strategy and ideas of security more generally and how Australia might respond to them, as I will argue below.

Second, proposals have been raised recently for SDSC to be moved out of the Coral Bell School of Asia Pacific Affairs to become part of the Crawford School of Public Policy at ANU. In my view, that proposal is to be strongly rejected. It is crucial that we stay in close contact with particular parts of the College of Asia and the Pacific because of their knowledge of key countries in Australia's strategic environment—especially

10 Bull, 'Strategic studies and its critics', p. 14.

11 Ibid., p. 21.

12 O'Neill, Strategic Studies and Political Scientists, p. 5. 
South-East Asia (particularly Indonesia), the South Pacific (particularly Papua New Guinea) and North-East Asia (especially China and Japan). These are countries that define Australia's strategic neighbourhood and where Australia has particular responsibilities and concerns. Little of this expertise exists in the Crawford School of Public Policy.

Third, unlike 20 years ago when I headed the Centre, SDSC faces an array of competing organisations that have specialised in particular areas. The Australian Strategic Policy Institute (founded in 2001) focuses heavily on defence policy from a practical perspective, offering alternative policy advice to the government from that of the defence organisation. Then there is the Lowy Institute (founded in 2003) with its wide international political mandate, the National Security College (founded in 2010) with its focus on national security issues and the education of public servants, and the US Studies Centre (founded in 2006) with its concentration on the United States and Australia's relations with it. There are other organisations that cater for a broader audience, such as the Kokoda Foundation (now renamed the Institute for Regional Security), as well as a growing number of university departments studying and teaching international strategic subjects.

All this has encouraged SDSC to focus more on what should be its primary educational purpose, which is to teach strategic studies and defence policy at the undergraduate and postgraduate levels. As a result, there has been a huge expansion in the Centre's teaching responsibilities with a master's program at ANU numbering about 70 students and an undergraduate program currently involving some 280 enrolments, as well as a highly successful master's program for the Command and Staff College course at the Australian Defence College. The size and diversity of this teaching program is without parallel anywhere else in Australia. It gives SDSC the opportunity to train the next generation of strategic thinkers nationwide, and we need to pay more attention to this goal and developing strong alumni linkages.

At the same time, the Centre needs to think carefully about the quickly growing number of new national security issues that are being raised for academic research and teaching. For example, what should be the contribution of strategic studies to such topics as terrorism, cyber warfare and climate change? Arguably, all three of these are of concern to a nation's national security. The current wave of extremist Islamic terrorism is an enormous threat to the very fabric of Western civilisation. Understanding 
the origins of terrorism, why it has been spawned by a particular extremist interpretation of the Islamic faith and how to counteract it are extremely challenging questions for governments. SDSC currently has no expertise in this area, although in the past it had one person who was a long-established terrorism expert. However, studying terrorism demands a different set of intellectual methodologies from traditional strategic studies of powerbased relations between nation states. It requires a deep knowledge of Islam, its Middle Eastern origins and - not least-the backgrounds and actions of individual terrorists. My view is that this is a highly specialised area and is more appropriately located in such institutions as national security colleges and university departments specialising in terrorism.

Similarly, the threat from cyber attacks and understanding both defensive and offensive retaliatory measures demands very specialised technical expertise that few academics yet possess. Moreover, the demand for this specialised knowledge is high, not only from governments but also from the private sector, given their vulnerabilities to penetration from foreign governments and individual hackers. Again, my view is that the intellectual and technical skills demanded are very different from conventional academic training, at least in the social sciences, so we are better off leaving it to such organisations as the Australian Strategic Policy Institute, which has established a specialised International Cyber Policy Centre that produces an annual report called Cyber Maturity in the AsiaPacific Region, which has become the definitive work on this topic. ${ }^{13}$ This publication is the result of 12 months of research and analysis delving into the cyber maturity of 20 countries in our region. I see no point in SDSC seeking to allocate scarce academic resources to this space.

Finally, there is the vexed question of climate change. There can be no doubt that this is a legitimate area for academic research, including in the broader strategic studies arena. The defence organisations of both the United States and the United Kingdom have identified it as an area of strategic concern, although the Australian 2016 Defence White Paper makes no specific reference to the challenges of climate change (whereas it does address the threats from terrorism and cyber attacks). ${ }^{14}$ The security threat from climate change gets only a passing reference in the White

13 Tobias Feakin, Jessica Woodall and Liam Nevill, Cyber Maturity in the Asia-Pacific Region 2015, International Cyber Policy Centre, Australian Strategic Policy Institute, October 2015.

14 Australian Government, 2016 Defence White Paper, Department of Defence, Commonwealth of Australia, Canberra, 2016, pp. 46-8, 51-2, www.defence.gov.au/WhitePaper/Docs/2016-DefenceWhite-Paper.pdf (retrieved 16 January 2018). 
Paper, being identified as 'a major challenge for countries in Australia's immediate region'. ${ }^{15}$ This statement is made in the context that increased sea-level rises and the frequency and intensity of extreme weather events 'will exacerbate the challenges of population growth and environmental degradation, and will contribute to food shortages and undermine economic development'. ${ }^{16}$

However, the Defence White Paper offers little practical guidance about the implications of this for the Australian Defence Force, other than helping Pacific island countries build their resilience to natural disasters. ${ }^{17}$ Humanitarian assistance and disaster relief missions are obviously an important ADF contribution to the security of the South Pacific. But the White Paper does not address the implications of severe climate-induced inundation of low-lying, vulnerable South Pacific countries. It is a major deficiency in the Defence White Paper that the strategic implications of such events are not addressed. There is important research work here for SDSC to do in cooperation with the world-class academic expertise on the South Pacific resident in The Australian National University's College of Asia and the Pacific.

\section{Priorities for strategic studies in the 2020s}

Longer-term priorities for academic strategic studies research will depend on events as they unfold, not least because of unpredictable 'black swan' shocks to the system such as the collapse of the Soviet Union or the election of Donald Trump as President of the United States. But some potentially threatening new trends can be identified now. In my view, we are entering an exceedingly dangerous era for which we are ill-prepared intellectually. My basic thesis is that forces of anti-Western nationalism are on the rise in Russia and China at the same time as Western democracies are being undermined by extreme Islamic terrorism assaults and the growth of xenophobic domestic attitudes to the outside world, as we have witnessed in the US presidential election in November 2016. We do not have a term yet for this new instability, but it should focus around unpredictable new nationalisms. Of course, nationalism has raised its ugly head before in recent history. As Barbara Tuchman observes in her book

15 Ibid., pp. 55-6.

16 Ibid.

17 Ibid., p. 74. 
The Proud Tower, the last time events of this sort coincided in the same way was between 1890 and $1914 .{ }^{18}$ That period was a pivotal moment in world history when widespread, violent anarchist terrorism and the helplessness of society to defend itself occurred at precisely the same time as the geopolitical challenge to the established power of Great Britain from the rising military power of Germany. The nations of the West were self-satisfied and setting themselves up, all unwittingly, for the catastrophe to come in World War I. This was a time of the most accelerated rate of change in human experience as industrial and scientific revolutions were transforming the world and undermining traditional employment certainties. The parallels with today are unsettling. I am not predicting here that history will repeat itself, but we are entering a dangerous era because of the following coincidence of events:

- Russia and China, both authoritarian powers, are challenging the Western liberal order through the use of military force and coercion. They are aligned in their hostility towards the United States and its democratic allies and are now seeking to alter international borders and extend their territories-for example, in the South China Sea and Ukraine. Unlike Russia, China is not yet using military force to assert its territorial claims, but it is using such harsh coercion and militarisation of its territorial claims that it is causing serious alarm in its neighbourhood.

- All this is occurring just as Western electorates are experiencing a yawning gap between governments and governed. Domestic politics in the West are in disarray as a result of the impact of globalisation, illegal immigrants and the control of borders. There is deep-seated anger in the United States and United Kingdom as well as other European countries about the loss of jobs and falling living standards. Governments are becoming increasingly challenged by the effects of globalisation on their domestic politics. A new political divide is occurring in Western democracies in which populous, xenophobic and anti-globalist politicians are on the rise and promising to put up walls to keep out the world. We have witnessed these dramatic forces at work most dramatically in recent years in both the United States and Britain.

18 Barbara W. Tuchman, The Proud Tower: A Portrait of the World Before the War, 1890-1914, Hamish Hamilton, London, 1966. 
- At the same time, Western democracies are facing an unprecedented assault by Islamic fundamentalist terrorists. This has now become so intense and on such a scale that, for example, fears have been expressed by the head of France's domestic intelligence organisation of civil war erupting. The very basis of Western civilisation is being deliberately undermined.

The above suggests some new research agendas for strategic studies, including the need for better analysis of the military capabilities of China and their implications for Australia. This means having a dedicated academic position to research independently the details of China's strategic policies and its military strengths and weaknesses. Understanding China is now a crucial strategic question for Australia.

Nuclear deterrence is re-emerging as a serious topic for research. Nuclear capabilities and their potential use is an area where the end of the Cold War and the disappearance of the threat of global nuclear war has led to complacency about these hugely destructive weapons. This is especially of concern in our own region, where there is a strong latent potential in several countries to acquire nuclear weapons with comparatively little warning.

The economic geography of globalisation and its implications for social and political stability in Western countries now warrants the recruitment of an economist with geographical skills and knowledge about how economic and technical globalisation affects countries-and specific regions within countries_-in different ways strategically.

We will need access to research on the implications of extreme Islamic fundamentalist terrorism for stability in key Western countries that are allies of the United States. This does not mean that strategic studies should now become expert on the details of terrorist attacks. Rather, we need deep insights into the implications of terrorism for the fundamental social cohesion of nation states in the West.

The implications of President Trump in Washington for security in the Asia-Pacific region demand a rethink of Australia's security outlook and the fundamental basis of our alliance with the United States so that we understand the policy choices now facing us. The most radical change to our national security policy settings since World War II has occurred with the election of Trump as President of the United States. This should be an important task for The Australian National University's Coral Bell 
School of Asia Pacific Affairs. It will involve bringing together strategic studies, international relations and area expertise on both our region and the United States in fundamental new ways.

With regard to defence policy, SDSC needs to return to its core business and rebuild its expertise in this traditional area of its research. We need to reappraise regularly the conclusions set forth in the 2016 Defence White Paper to challenge their continuing validity. For example, some groundbreaking research needs to be undertaken about the implications for Australia if the comfortable timeframes of the 2016 Defence White Paper are wrong: such as the assertion that 'there is no more than a remote possibility of a military attack on Australian territory by another country in the period to $2035^{\prime} .{ }^{19}$ What I have in mind here is that we need to be prepared for a quicker deterioration in our fundamental strategic circumstances if China's military ambitions result in armed conflict with the United States and Japan. This would have important implications for the expansion base of the ADF and for its mobilisation.

Our role in education could be taken a bit higher up the scales of seniority and responsibility by hosting discussion groups, small conferences and one-on-one sessions involving senior public servants and military officers, diplomats and rising young politicians. ${ }^{20}$ These need not be very timeconsuming but would be arranged to be a good fit between student and teacher, and could be coordinated with other relevant parts of ANU, other universities and perhaps with key regional strategic studies centres. The major political parties and relevant parliamentary committees might welcome more such interaction with the Strategic \& Defence Studies Centre.

Finally, there is the question of where policy-relevant work should figure in the research priorities of strategic studies in the second decade of the 21 st century. There is growing recognition of the practical value of such research in Australian universities. However, as there was in Hedley Bull's day, there is lively debate today as to whether it is appropriate for academics in strategic studies to give consideration to the implications of their scholarly work for the policies of governments. At a time when so many of the challenges I have mentioned are arising, this is said to be a very important part of The Australian National University's stated

19 Australian Government, 2016 Defence White Paper, p. 40.

20 I am indebted to Professor R.J. O'Neill for the suggestions in this paragraph. 
strategic plan and mission. However, it still seems to be the case that some in academia consider it is not appropriate to suggest what are the implications of their scholarly work for Australian policy. While respecting their views, and without sacrificing academic independence, I consider it behoves us to inform the wider Australian community appropriately about such serious national security policy questions. 



\section{Appendix 1: Strategic \& Defence Studies Centre 50th anniversary celebratory dinner keynote speech: 'To see what is worth seeing'}

\section{Brendan Sargeant}

It is a great privilege and pleasure to be here this evening to give the keynote speech at this celebratory dinner for the 50th Anniversary of the Strategic \& Defence Studies Centre.

Let me offer my congratulations on the Centre's 50th anniversary. I think the conference topic, 'New Directions in Strategic Thinking 2.0', is absolutely the right question to be exploring.

It is good to see so many familiar faces here tonight. Some people here I have worked with, and they have given me immeasurable help and guidance over the years. Others I know because I have read their work and pondered and learned from it.

I speak not only for myself but also on behalf of Defence when I say that the SDSC has made a huge contribution to strategic policy-making in Australia over many years, a contribution of incommensurable value to Australia. From my perspective, it has enriched the policy environment and deepened understanding of the world we live in and the nature of the choices that we make as we find our way in that world. Long may it be so.

To speak before such an illustrious audience is a daunting prospect. I am very conscious that almost anything I might talk about is likely to be familiar ground to many here. 
I am not going to talk about recent Defence White Papers, or the South China Sea, or the emerging Indo-Pacific. If you are looking for advice on government policy, there are plenty of documents available. If you are looking for an expert commentary, there are people in this room better qualified than me.

What I would like to talk about is the importance of strategy and its value to large institutions - and most especially one I know intimately, the Department of Defence.

But first I would like to digress with a couple of anecdotes to set the framework for my discussion.

Many years ago, I was haunting a bookshop somewhere in Little Collins Street in Melbourne, a bookshop that no longer exists, which sold books that were well beyond my price range at that time. One day when I was there, I came across a book that had just been published. It was called The Plains by Gerald Murnane.

For some reason, I purchased it - spending more money than I could afford-and took it home and read it. It was one of those books that turns you five degrees off centre from the rest of the universe and gives you a completely different picture of the world. Nothing is quite the same after reading it. I think it is one of the greatest Australian books, and it has never left me.

The story is simple enough. A young man who describes himself as a filmmaker decides to leave Outer Australia and journey to a place called Inner Australia.

Inner Australia is the landscape of the plains where a vast and complex culture has been built and sustained by a wealthy landholding aristocracy. These landholders are patrons of the arts and sciences. They are obsessed by the landscape of the plains, which is their landscape. They devote endless resources to discover the true meaning of the plains, to get an understanding of what they really are, for in knowing the world, their world, they will know themselves. They also know their quest is endless and perhaps futile.

The filmmaker meets these landowners and goes through a process of auditioning. Eventually he is employed by one of the landowners to be a resident filmmaker on his estate. The landowner expects nothing from this filmmaker, but believes that he might one day be capable of 'seeing 
what was worth seeing'. The book then describes the filmmaker's life thereafter. Needless to say, no film is ever made, but the filmmaker goes into an endless and enriching exploration of the plains in this place called Inner Australia.

The book struck me with the force of revelation, for even though it was clearly a work of fantasy or speculative fiction, it described to me absolutely the reality of Australian culture in the world that I was living in. What I realised was that there is a world, but there are many different ways of describing it, and that these can create a richer sense of reality because the process illuminates what might not have been seen. The book is very rich and can be considered in many different ways, but the opposition set up between an Outer Australia_ an Australia that is self-satisfied and feels that it knows reality—and an Inner Australia — where the culture is devoted to finding the meaning behind appearances-is worth reflecting on. I will come back to this, but I believe that the work of strategy is the work of this Inner Australia.

My second anecdote relates to my recent visit to Exercise Hamel, a large army exercise that took place in Cultana, a bleak and beautiful place in South Australia. I visited the exercise and had fun seeing what the army does when it is being itself.

In the exercise headquarters, the place where the exercise was managed, I saw a map on the wall which was very familiar to me-it hangs in my office-except that just north-east of the archipelago to our north was another country called Kamaria.

I spent some time contemplating this map, the geography and contours of this imaginary country inserted in a real world, and I remarked to one of my companions that there was an enormous amount of strategic policy history embedded in that simple map. One of the generals said to me: 'They're tough, those Kamarians. We've been fighting them for 40 years.'

What intrigued me, and continues to intrigue me, is how in order to understand ourselves better we construct an imaginary country against which we define ourselves and test our ideas.

I work in an organisation called the Department of Defence that does many different things every moment of the day. It never sleeps. It never stops. It is relentless. It has its own imperatives and appetites. It has 
a personality and life independent of those people and organisations that contribute to its being. It is what it is and, in its deepest dreaming, has no desire but to be what it is.

Most of my work is an attempt to help manage this vast enterprise. The practical reality is that I make lots of micro decisions or supervise the work of others who also make decisions or provide advice to more senior decision-makers.

In this world, strategy can be a distant reality, a quiet voice behind the noise and clutter of the daily routine. Yet I never forget what one of my teachers once said to me: 'Listen to the quiet voice!'

The essence of my management task, as is also that of my colleagues, is to ensure that what this organisation does conforms to government policy and embodies in its activities the strategy that the government has signed up to in its policy documents. These include, most importantly, the White Paper and the subsidiary documents that flow from it, such as the Defence Planning Guidance and the Australian Military Strategy.

What I have seen over the years is a continuing tension between the imperatives of the institution, its personality and its own desires, to speak metaphorically, and the requirements of government as expressed in policy and strategy. In this sense, strategy is the quiet voice that calls the organisation away from itself and requires that it look out into the world and respond accordingly. For this reason, the strategic policy function is central to organisational health and well-being and is critical if the organisation is to remain relevant.

One of the features of the current environment is that there is an overwhelming emphasis-and rightly so-on sustaining operations. The challenge is to step back from this immediacy to reflect on the nature and meaning of the larger story that we are telling through what we do. The institution will tell its own story if left to itself. The task of strategy is to make it listen and understand that the reality it sees itself as part of can have many dimensions and actually be something other than what it thinks it is.

We do not have many strategists in Defence. That is not a bad thing, as long as we listen to what they are saying. This I think is the hardest part of working in a large organisation. It is developing the capacity to listen to the other voice-to journey into Inner Australia, so to speak. 
What are we doing when we do strategy?

When I reflect on the strategic history of Australia filtered through the development of the Defence organisation, along with the successive documents to chart that development—primarily White Papers-what I hear is an ongoing conversation. It is a conversation about who we are. It is a conversation about what sort of country we are and how we should participate in the world. This conversation takes expression in the capabilities we build, in our operational commitments and in our relationships with other countries.

I could trace the history of strategic thought over the time I have been associated with the Department of Defence. Its main narrative arc goes something like this: in the time after the Vietnam War, we started the process of thinking of ourselves as a strategic entity separate from the larger system in which we had participated since Federation. There were many debates, some still alive today. This thinking expressed itself in a policy and a strategy that was called self-reliance and had many dimensions in terms of how we organised the department, began the work of building the modern ADF [Australian Defence Force], and participated in the world.

This was essentially a nationalist project, and an important one. I also think it was part of a larger project of Australia rethinking its place in the world in the post-Vietnam era. The intervention in East Timor might be seen as an expression of that policy and strategy and the arena where its strengths and flaws were highlighted. It is a strategy that has never gone away.

Since Timor and particularly since $9 / 11$, our governments have pursued a fairly active engagement of the ADF in many different parts of the world. This reflects, I think, a sense that Australia has global interests and needs to support them, including through the use of the Defence Force. Our strategy in this context might be seen as a response to globalisation and an attempt to respond to some of the more malignant forces unleashed by globalisation in ways that support our national interests. Whether our strategy has been sufficient for the environment we are in is a debate for another time.

I see the recent White Paper as a culmination of a journey that began decades ago in that it seeks to recognise that Australia is not only a country that lives geographically in the Indo-Pacific, but also has trading 
and national interests that extend across the world. How we balance the local with the global is an enduring tension in policy-making and strategy development. It is the location of most serious debates about defence policy.

So I see our strategic thinking as partly the telling of a story about who we are and, more importantly, who we think we are. It is a story that never ends, but will evolve and be reinterpreted over time as events occur and we respond. Most importantly, it is a story we tell both through what we say and what we do.

I am not one of those people who says that the current environment is more difficult or more challenging than the environment faced by our predecessors. I think that is simply being arrogant and historically myopic. Each time has its own demands, and every strategic challenge is new to those who have to face it. However, I do believe that we are in one of those moments in history where we are moving from one world to another. The strategic challenge before us is to make the transition successfully.

When you are confronted by a genuinely strategic decision, or there is a genuine strategic change in the environment in which you are, the challenge is not just a challenge of how you might respond to that environment by taking various forms of action. It is also a challenge to your self-conception, to your sense of who you are and who you might be. This is why strategic choices are hard and, I think, difficult for our institutions, which can grow comfortable with a sense of things as they are.

It is also why doing the work of strategy is hard. And it should be hard, really hard-emotionally, as well as intellectually.

Many of the contemporary challenges to security are also challenges that go to our sense of what sort of country we are and what we need to become. Some of these challenges have the potential to render the assumptions upon which we take action redundant or meaningless.

To take some examples:

- The assumptions that underpinned the current rules-based global order are increasingly being challenged, and are increasingly challengeable.

- Military power is increasingly a commodity, and the ability to generate strategic effects is being democratised. We have all seen what one person with a semi-automatic weapon can do. 
- We cannot assume that all players in our strategic environment are rational, or that they share our assumptions about how the world and conflict should be managed.

- It is not so easy any more to distinguish between the world within our national borders and the world outside.

- We are seeing genuinely transformational technologies-cyber, quantum computing, autonomous systems, and so on.

The task of strategy is more complex because it has to speak to many different realities and many different perceptions of what reality might or should be. It has to do this in a way that helps policy and decision-makers thread their way through to a course of action or decision.

Our response to these challenges, along with others that will emerge in coming decades, will change us. How do we understand and manage that change while also responding to what the world brings? Some of our choices will be constrained by our self-conception. We need to understand this as well.

What I worry about is whether we are truly seeing reality. Our institutional imperatives are, in my experience, so potentially powerful that they can blind us to aspects of the world that we live in. Do we prefer to be what we are rather than to consider what we need to be if we are to respond to contemporary realities? What are the costs of the choices that we might need to make, and do we really understand what those choices are? In a world of wicked problems - and strategic problems are all wickeddo we prefer our tried and true solution sets rather than seeing what is worth seeing?

When I looked at that map at Exercise Hamel and saw the country of Kamaria, I asked myself a question. In creating an imaginary country that we have used to define and test ourselves against, have we simply created another reflection of what we are and what we are comfortable with being?

When I think of that young man in that imaginary world of the plains commencing his lifelong journey to discover the true meaning of the plains-an impossible but necessary quest-I see it as a wonderful metaphor for the work that all of us do. I am most of all taken by the landowner's implicit request that he come to see what was worth seeing. The landowner understood that this might be the work of a whole lifetime. 
Sometimes when I read the work of people who do strategy, including people at the Strategic \& Defence Studies Centre, the practical administrator in me gets irritated because it just complicates my decisionmaking and I prefer a smooth and easy life. It puts in front of me those most terrifying of all questions for an administrator: Have I got it right? Is what we are doing making sense? Do we really understand what we are dealing with?

When I am in a better, less harassed mood, I appreciate how valuable that work is. And I treasure it.

Sometimes I look at much of the writing on strategy, and it is like wandering through a library of books about things that have never happened. Sometimes it is quite a strange experience to read these forlorn prophecies that have never come true. Yet, despite this, how important it is that we have these works of imagination, these documents of grim speculation and melancholy advice. They can be books of magic. Sometimes the writing of them ensures that what they talk about does not occur. They intersect with reality to help us understand that the reality is more complex and more multidimensional and has more that is imponderable than we are ever quite comfortable with. They help us make choices that change reality.

This conversation, which we call strategy-making, helps us understand the world around us and helps us understand the consequences of the choices that we might make or not make. It helps us change the world.

So, to the Strategic \& Defence Studies Centre, let us have another 50 years of thinking and conversation and research.

Continue the great work of building a strategic conversation in Australia about who we are and what we might become.

Help us understand the choices and pathways that might take us there.

Help us to see what is worth seeing.

Brendan Sargeant

Associate Secretary

Department of Defence

21 July 2016 


\title{
Appendix 2: Conference program
}

\author{
The Hall, University House, The Australian National \\ University, Canberra, Australia
}

\section{Day 1: Thursday, 21 July 2016}

\begin{tabular}{|c|c|}
\hline Conference opening & Dr Brendan Taylor \\
\hline Keynote address: Strategic Thinking Since 1945 & Professor Sir Lawrence Freedman \\
\hline \multicolumn{2}{|l|}{ Student Awards Presentation } \\
\hline \multicolumn{2}{|c|}{ Session 1: Strategy and Power (Chair: Professor Michael Wesley) } \\
\hline 21st Century Strategic Order & Dr C. Raja Mohan \\
\hline Economics and Strategy & Dr Amy King \\
\hline Elements of National Power and Strategic Policy & Major General John J. Frewen \\
\hline Great Power Grand Bargains: Myth or Reality? & Professor Evelyn Goh \\
\hline \multicolumn{2}{|c|}{$\begin{array}{l}\text { Session 2: Strategic Thinking: Concepts and Challenges (Chair: Emeritus Professor } \\
\text { David Horner) }\end{array}$} \\
\hline $\begin{array}{l}\text { Old Wine in New Bottles? The Continued } \\
\text { Relevance of Cold War Strategic Concepts }\end{array}$ & Professor Robert Ayson \\
\hline Alliances After the Cold War & Professor Thomas Christensen \\
\hline Nuclear Strategy After the Cold War & Dr Nicola Leveringhaus \\
\hline \multicolumn{2}{|c|}{ Session 3: Strategy and Domains (Chair: Professor Joan Beaumont) } \\
\hline The Return of Geography & Professor Paul Dibb \\
\hline Maritime Strategy in Asia & Dr Euan Graham \\
\hline $\begin{array}{l}\text { The Evolution of Military Capability in the } \\
\text { Indo-Asia-Pacific Region }\end{array}$ & Dr Tim Huxley \\
\hline Summary & Dr Brendan Taylor \\
\hline \multicolumn{2}{|c|}{$\begin{array}{l}\text { Strategic \& Defence Studies Centre 50th Anniversary Celebratory Dinner (Australian } \\
\text { War Memorial) }\end{array}$} \\
\hline Keynote address: To See What is Worth Seeing & Brendan Sargeant \\
\hline
\end{tabular}




\section{Day 2: Friday, 22 July 2016}

\begin{tabular}{|l|l|}
\hline Welcome & Dr Brendan Taylor \\
\hline \multicolumn{2}{|l|}{ Session 4: Strategic Studies in Practice (Chair: Admiral Chris Barrie) } \\
\hline $\begin{array}{l}\text { Strategic Studies in Practice: The Australian } \\
\text { Perspective }\end{array}$ & Professor Hugh White \\
\hline $\begin{array}{l}\text { Strategic Studies in Practice: The South-East } \\
\text { Asian Perspective }\end{array}$ & Mr Peter Ho \\
\hline $\begin{array}{l}\text { Training the Next Generation of Strategic } \\
\text { Thinkers }\end{array}$ & Professor Eliot Cohen \\
\hline Session 5: New Directions in Strategic Studies (Chair: Professor Daniel Marston) \\
\hline US Grand Strategy in the Post-Cold War Era & Dr Hal Brands \\
\hline $\begin{array}{l}\text { The Future of Strategic Studies: Lessons from } \\
\text { the Last Golden Age }\end{array}$ & Professor Sir Hew Strachan \\
\hline An Asian School of Strategic Studies? & Professor Amitav Acharya \\
\hline $\begin{array}{l}\text { The Future of Strategic Studies: The Next } \\
\text { Golden Age }\end{array}$ & Professor Robert O'Neill \\
\hline Where to From Here? & Professor Bates Gill \\
\hline Concluding Remarks & Dr Brendan Taylor \\
\hline
\end{tabular}




\section{Bibliography}

Acharya, Amitav, 'Engagement or entrapment: Scholarship and policy-making in Asian regionalism', International Studies Review 13, no. 1, 2011, pp. 12-17. doi.org/10.1111/j.1468-2486.2010.00993.x

—_, 'The idea of Asia', Asia Policy, no. 9, 2010, pp. 32-9

- 'Narrowing the academia-policy divide in international relations', East Asia Forum, 20 May 2014, www.eastasiaforum.org/2014/05/20/narrowingthe-academia-policy-dividein-international-relations/ (retrieved 1 February 2018)

Allison, Graham and Philip Zelikow, Essence of Decision, 2nd edn, AddisonWesley, New York, 1999

Andreani, Gilles, 'The disarray of US non-proliferation policy', Survival 41, no. 4, 1998, pp. 42-61. doi.org/10.1093/survival/41.4.42

Arkin, William and Hans Kristensen, 'Dangerous directions', Bulletin of Atomic Scientists 52, no. 2, 1998, pp. 26-31

Australian Government, 2016 Defence White Paper, Department of Defence, Commonwealth of Australia, Canberra, 2016, pp. 46-8, 51-2, www.defence. gov.au/WhitePaper (retrieved 16 January 2018)

Australian Strategic Analysis and Defence Policy Objectives, September 1976, in A History of Australian Strategic Policy Since 1945, ed. Stephan Fruehling, Defence Publishing Service, Canberra, 2009

Ayson, Robert, Asia's Security, Palgrave Macmillan, London, 2015. doi.org/ 10.1007/978-1-137-30183-3

- Hedley Bull and the Accommodation of Power, Palgrave Macmillan, London, 2012 
- ' 'Selective non-proliferation or universal regimes?', Australian Journal of International Affairs 59, no. 4, 2005, pp. 431-7. doi.org/10.1080/ 10357710500367232

_- Thomas Schelling and the Nuclear Age: Strategy as Social Science, Frank Cass, London, 2004

Baijie, An and Fu Jing, 'Ruling "null and void", with no binding force', China Daily USA, 13 July 2016, usa.chinadaily.com.cn/epaper/2016-07/13/ content_26073364.htm (retrieved 26 August 2017)

Ball, Desmond, 'Strategic culture in the Asia-Pacific Region', Security Studies 3, no. 1, 1993, pp. 44-74

Ball, Desmond and Amitav Acharya (eds), The Next Stage: Preventive Diplomacy and Security Cooperation in the Asia-Pacific Region, Strategic \& Defence Studies Centre, The Australian National University, Canberra, 1999

Barbieri, Katherine, 'Economic interdependence: A path to peace or a source of interstate conflict?', Journal of Peace Research 33, no. 1, 1996, pp. 29-49. doi.org/10.1177/0022343396033001003

Barney, Jay and William Hesterly, Strategic Management and Competitive Advantage: Concepts, 2nd edn, Pearson, Upper Saddle River, 2007

Barnhart, Michael A., Japan Prepares for Total War: The Search for Economic Security, 1919-1941, Cornell University Press, Ithaca and London, 1987

Bell, Coral, The Conventions of Crisis: A Study in Diplomatic Management, Oxford University Press for Royal Institute for International Affairs, London, 1971

'A Preoccupation with Armageddon' (unpublished memoir), Canberra, 2012

Blanchard, Jean-Marc F., Edward D. Mansfield and Norrin M. Ripsman, Power and the Purse: Economic Statecraft, Interdependence, and National Security, Frank Cass, London, 2000

Bloch, Marc, Strange Defeat: A Statement of Evidence Written in 1940, W.W. Norton, New York, 1999

Bracken, Paul, 'Net assessment: A practical guide', Parameters, Spring 2006, pp. $\quad 90-100, \quad$ strategicstudiesinstitute.army.mil/pubs/parameters/articles/ 06spring/bracken.htm (retrieved 13 March 2018)

Brands, Hal, American Grand Strategy in the Age of Trump, Brookings Institution Press, Washington, DC, 2018 
—- From Berlin to Baghdad: America's Search for Purpose in the Post-Cold War World, University Press of Kentucky, Lexington, 2008

- Making the Unipolar Moment: US Foreign Policy and the Rise of the PostCold War Order, Cornell University Press, Ithaca, 2016

__, 'US grand strategy: Not so bad after all', American Interest 12, no. 3, 2017, pp. 6-17

Brodie, Bernard, 'The absolute weapon', in Strategic Studies: A Reader, ed. Thomas G. Mahnken and Joseph A. Maiolo, Routledge, London, 2008

— - A Layman's Guide to Naval Strategy, Oxford University Press, London, 1943

—, Sea Power in the Machine Age, Princeton University Press, Princeton, 1941

_, War and Politics, Macmillan, New York, 1973

Brodie, Bernard (ed.), The Absolute Weapon, Harcourt Brace, New York, 1946

Brooks, Stephen and William Wohlforth, 'The once and future superpower: Why China won't overtake the United States', Foreign Affairs 95, no. 3, 2016, pp. 91-104

- 'The rise and fall of the Great Powers in the twenty-first century', International Security 40, no. 3, 2015-16, pp. 7-53

Brown, James, 'Firing line: Australia's road to war', Quarterly Essay 62, 2016, pp. 1-68

Bull, Hedley, The Control of the Arms Race: Disarmament and Arms Control in the Nuclear Age, Weidenfeld \& Nicolson, London, 1961

— 'Force in international relations: The experience of the 1970s and prospects for the 1980s', in New Directions in Strategic Thinking, ed. Robert O'Neill and D.M. Horner, George Allen \& Unwin, London, 1981

— 'The great irresponsibles? The United States, the Soviet Union and world order', International Journal 35, no. 3, 1980, pp. 437-47. doi.org/10.1177/ 002070208003500302

- ' 'International relations as an academic pursuit', Australian Outlook 26, no. 3, 1972, pp. 251-65. doi.org/10.1080/10357717208444445

- 'Review of Arms and Influence by Thomas C. Schelling', Bulletin of the Atomic Scientists 23, no. 3, 1967, pp. 25-6 
, 'Society and anarchy in international relations', in Diplomatic Investigations, ed. Herbert Butterfield and Martin Wight, Allen \& Unwin, London, 1966, pp. $35-50$

—_, 'Strategic studies and its critics', World Politics, July 1968, pp. 593-605; reprinted in Hedley Bull on Arms Control, ed. Robert O'Neill and David N. Schwartz, St Martin's Press, New York, 1987, pp. 11-24

Bush, George W., 'Speech on missile defence', at the National Defense University, Washington, DC, 1 May 2001, fas.org/nuke/control/abmt/news/ 010501bush.html (retrieved 29 January 2018)

Bush, Richard C., At Cross Purposes: US-Taiwan Relations since 1942, M.E. Sharpe, Armonk, 2004

- Unchartered Strait: The Future of China-Taiwan Relations, Brookings Institution Press, Washington, DC, 2013

Butterworth, Robert and John Sheldon, Deterrence in Space: Responding to Challenges to the US in Outer Space, George Marshall Institute, Washington, DC, November 2008

Buzan, Barry, 'Economic structure and international security: The limits of the liberal case', International Organization 38, no. 4, 1984, pp. 597-624. doi.org/10.1017/S0020818300026886

Centre for Strategic Futures and Civil Service College, 'Foresight: A glossary', Singapore, Centre for Strategic Futures, Public Service Division, Civil Service College, undated, www.csf.gov.sg/docs/default-source/default-document-library /csf-csc_foresight--a-glossary.pdf (accessed 18 June 2018)

Chan, Steve, Looking for Balance: China, the United States and Power Balancing in East Asia, Stanford University Press, Stanford, 2012. doi.org/10.11126/ stanford/9780804778206.001.0001

Chapman, J.W.M., Reinhard Drifte and I.T.M. Gow, Japan's Quest for Comprehensive Security: Defence, Diplomacy, Dependence, Frances Pinter Publishers, London, 1983

Cheng, Jingye, 'Arbitration on South China Sea dispute fatally flawed', Australian, 14 July 2016, p. 12

Chicago Council on Global Affairs, America Divided: Political Partisanship and US Foreign Policy, October 2015 
Choong, William, 'The ties that divide: History, honour and territory in SinoJapanese relations', Adelphi 445, International Institute for Strategic Studies, London, 2014

Christensen, Thomas J., 'China, the US-Japan alliance, and the security dilemma in East Asia', International Security 23, no. 4, 1999, pp. 49-80. doi.org/ 10.1162/isec.23.4.49

- Useful Adversaries: Grand Strategy, Domestic Mobilization, and, SinoAmerican Conflict, 1947-1958, Princeton University Press, Princeton, 1996

Citino, Robert M., The Path to Blitzkrieg: Doctrine and Training in the German Army, 1920-39, Lynne Rienner, Boulder, 1999

Clark, Christopher, The Sleepwalkers: How Europe Went to War in 1914, Allen Lane, London, 2012

Clark, Ian, The Post-Cold War Order: The Spoils of Peace, Oxford University Press, Oxford, 2001

Clausewitz, Carl von, On War, ed. and trans. Michael Howard and Peter Paret, commentary Bernard Brodie Princeton University Press, Princeton, 1984

Clover, Charles, Black Wind, White Snow: The Rise of Russia's New Nationalism, Yale University Press, New Haven, 2016

Corum, James S., The Roots of Blitzkrieg: Hans von Seeckt and German Military Reform, Kansas University Press, Lawrence, 1992

Dargnat, Christian, 'China's shifting geo-economic strategy', Survival 58, no. 3, pp. $63-76$

Davis, Christina, 'Linkage diplomacy: Economic and security bargaining in the Anglo-Japanese alliance, 1902-23', International Security 33, no. 3, 2008-09, pp. 143-79. doi.org/10.1162/isec.2009.33.3.143

Davis, Christina L. and Sophie Meunier, 'Business as usual? Economic responses to political tensions', American Journal of Political Science, 55, no. 3, 2011, pp. 628-46. doi.org/10.1111/j.1540-5907.2010.00507.x

Delbrück, Hans, Geschichte der Kriegskunst im Rahmen der politischen Geschichte, G. Stilke, Berlin, 1900

—- Die Strategie des Perikles erlautert durch die Strategie Friedrichs des Grossen, Reimer, Berlin, 1890

Delpech, Theresa, Nuclear Deterrence in the 21st Century: Lessons from the Cold War for a New Era of Strategic Piracy, RAND, Santa Monica, 2012 
Desportes, Vincent, Tomorrow's War: The Art of War in the Modern World, Economica, Paris; French edn 2007; English edn 2009

Diamond, Larry, 'Facing up to the democratic recession', Journal of Democracy 25 , no. 1,2015 , pp. $141-55$

Dibb, Paul, 'SDSC in the nineties: A difficult transition', in A National Asset: Essays Commemorating the 40th Anniversary of the Strategic and Defence Studies Centre, ed. Meredith Thatcher and Desmond Ball, Strategic \& Defence Studies Centre, The Australian National University, Canberra, 2006, pp. 84-7

- , 'Why Russia is a threat to the international order', Australian Strategic Policy Institute Strategy paper, June 2016

Dibb, Paul and John Lee, 'Why China will not become the dominant power in Asia', Security Challenges 10, no. 3, 2014, pp. 1-21

Dizikes, Peter, 'When the butterfly effect took flight', MIT Technology Review, 22 February 2011, www.technologyreview.com/s/422809/when-the-butterfly effect-took-flight/ (retrieved 21 January 2018)

'DoD news briefing-Secretary Rumsfeld and Gen. Myers', US Department of Defense, archive.defense.gov/transcripts/transcript.aspx?transcriptid=2636 (retrieved 22 September 2016)

Doran, Charles F., 'Living with asymmetry', Mershon International Studies Review 38, no. 2, 1994, pp. 260-4. doi.org/10.2307/222720

Douhet, Giulio, The Command of the Air, Italian Ministry of War, Rome, 1921

Doyle, Thomas E. III, 'Reviving nuclear ethics: A renewed research agenda for the twenty-first century', Ethics and International Affairs 24, no. 3, 2010, pp. 287-308. doi.org/10.1111/j.1747-7093.2010.00268.x

Drifte, Reinhard, Japan's Security Relations with China since 1989: From Balancing to Bandwagoning?, Routledge Curzon, London, 2003

Dugin, Alexander, Last War of the World Island: The Geopolitics of Contemporary Russia, Arktos, London, 2015

Earle, Edward Mead, Gordon Alexander Craig and Felix Gilbert, Makers of Modern Strategy: Military Thought from Machiavelli to Hitler, Atheneum, New York, 1967

Economic Research Service, US Department of Agriculture, 'GDP Shares by country and region historical', www.ers.usda.gov/data-products/internationalmacroeconomic-data-set/ (retrieved 30 January 2018) 
Edwards, Peter, Arthur Tange: Last of the Mandarins, Allen \& Unwin, Sydney, 2006

Ehlert, Hans, Michael Epkenhans and Gerhard Gross, Der Schlieffenplan: Analysen und Dokumente, Schöningh, Paderborn, 2006

Ekbladh, David, 'Present at the creation: Edward Mead Earle and the Depressionera origins of security studies', International Security 36, no. 3, 2011-12, pp. 107-41. doi.org/10.1162/ISEC_a_00067

Evans, Richard J., Altered Pasts: Counterfactuals in History, Little, Brown \& Company, London, 2016

Feakin, Tobias, Jessica Woodall and Liam Nevill, Cyber Maturity in the AsiaPacific Region 2015, International Cyber Policy Centre, Australian Strategic Policy Institute, October 2015

Feaver, Peter and Stephen Biddle, 'Assessing strategic choices in the War on Terror', in How 9/11 Changed Our Ways of War, ed. James Burk, Stanford University Press, Stanford, 2014

Ferguson, Niall, The Pity of War, Allen Lane, London, 1998

Ferguson, Niall (ed.), Virtual History: Alternatives and Counter-factuals, Picador, London, 1997

Finch, Michael P.M., 'Edward Mead Earle and the unfinished Makers of Modern Strategy', Journal of Military History, 80, no. 3, 2016, pp. 781-814

Foot, Rosemary, 'China and the United States: Between cold and warm peace', Survival 51, no. 6, 2009-10. doi.org/10.1080/00396330903461708

Freedman, Lawrence, The Evolution of Nuclear Strategy, 2nd edn, Macmillan/ St Martin's Press with the International Institute for Strategic Studies, Basingstoke and New York, 1989. doi.org/10.1007/978-1-349-20165-5

- The Evolution of Nuclear Strategy, 3rd edn, Palgrave Macmillan, London, 2003

—, Strategy: A History, Oxford University Press, Oxford and New York, 2013

Freedom House, Freedom in the World 2013: Democratic Breakthroughs in the Balance, 2013, p. 29, freedomhouse.org/report/freedom-world/freedomworld-2013 (retrieved 30 January 2018)

Frieser, Karl-Heinz, Blitzkrieg-Legende: Der Westfeldzug 1940, Oldenbourg, Munich, 1996 
Fuller, J.F.C., The Generalship of Alexander the Great, Rutgers University Press, New Brunswick, 1960

Gaddis, John Lewis, 'The long peace: Elements of stability in the post-war international system', International Security 10, no. 4, 1986, pp. 99-142. doi.org/10.2307/2538951

_- 'Signals and feedback in the arms dialogue', Bulletin of the Atomic Scientists 21, no. 1, 1965, pp. 5-10. doi.org/10.1080/00963402.1965.11454743

—-, Strategies of Containment: A Critical Appraisal of American National Security Policy during the Cold War, Oxford University Press, New York, 2005

Galula, David, Counterinsurgency Warfare: Theory and Practice, Praeger Security International, Westport, CT, 1964

—, Pacification in Algeria, 1956-1958, RAND, Santa Monica, 1963

Garamone, Jim, 'Rumsfeld details DoD goals, objectives in testimony', Department of Defense, Washington, DC, 12 January 2001, archive.defense. gov/news/newsarticle. aspx?id=45149 (retrieved 29 January 2018)

Gartzke, Erik, Quan Li and Charles Boehmer, 'Investing in the peace: Economic interdependence and international conflict', International Organization 55, no. 2, 2001, pp. 391-438. doi.org/10.1162/00208180151140612

Gat, Azar, The Origins of Military Thought from the Enlightenment to Clausewitz, Clarendon Press, Oxford, 1989

Gilpin, Robert, 'Economic interdependence and national security in historical perspective', in Economic Issues and National Security, ed. Klauss Knorr and Frank N. Trager, Regents Press of Kansas for the National Security Education Program, Lawrence, 1977

Glaser, Charles L., 'A US-China grand bargain? The hard choice between military competition and accommodation', International Security 39, no. 4, 2015, pp. 49-90

Goh, Evelyn, 'Is a "grand bargain” the way forward in North-East Asia?', Global Asia, Winter 2016, pp. 58-65

- ' 'Japan, China, and the Great Power bargain in East Asia', East Asia Institute Fellows Working Paper Series no. 32, November 2011, www.eai.or.kr/data/ bbs/eng_report/2011103118375220.pdf (retrieved 29 January 2018)

_- 'Making headway on the "economic-security nexus": Contributions from South-East Asia', Asan Forum 1, no. 3, 2013 
The Struggle for Order: Hegemony, Hierarchy, and Transition in Post-Cold War East Asia, Oxford University Press, Oxford, 2013

- 'The US-China relationship and Asia-Pacific security: Negotiating change', Asian Security 1, no. 3, 2005, pp. 216-44. doi.org/10.1080/ 14799850500341916

Goldstein, Avery and Edward D. Mansfield (eds), The Nexus of Economics, Security, and International Relations in East Asia, Stanford University Press, Stanford, 2012

Goodby, James, 'The nuclear dilemma: Constants and variables in American strategic policies', in The War That Must Never Be Fought: Dilemmas of Nuclear Deterrence, ed. George P. Shultz and James Goodby, Hoover Institution Press, Stanford, 2015, pp. 57-80, www.hoover.org/sites/default/files/research/ docs/goodby_shultz_-_the_war_that_must_never_be_fought_-_scribd.pdf (retrieved 29 January 2018)

Gowa, Joanne and Edward D. Mansfield, 'Power politics and international trade', American Political Science Review 87, no. 2, 1993, pp. 408-20. doi.org/ $10.2307 / 2939050$

Gray, Colin, Modern Strategy, Oxford University Press, Oxford, 1999

Grieco, Joseph M., 'Anarchy and the limits of cooperation: A realist critique of the newest liberal institutionalism', International Organization 42, no. 3, 1988, pp. 485-507. doi.org/10.1017/S0020818300027715

Grinius, Marius, 'Canada and Asia: Prosperity and security', Canadian Global Affairs Institute, policy paper, June 2015, d3n8a8pro7vhmx.cloudfront.net/ cdfai/pages/569/attachments/original/1436386569/Canada-Asia_ProsperitySecurity.pdf?1436386569 (retrieved 1 February 2018)

Hanson, Victor (ed.), Makers of Ancient Strategy: From the Persian Wars to the Fall of Rome, Princeton University Press, Princeton, 2010

Harris, Stuart, 'Policy networks and economic cooperation in the Asia Pacific', Pacific Review 7, no. 4, 1994, pp. 381-95. doi.org/10.1080/0951274 9408719109

Hartley, L. P., The Go-Between, Hamish Hamilton, London, 1953

Heuser, Beatrice, The Evolution of Strategy: Thinking War from Antiquity to the Present, Cambridge University Press, Cambridge, 2010. doi.org/10.1017/ CBO9780511762895 
Hirschman, Albert O., National Power and the Structure of Foreign Trade, University of California Press, Berkeley and Los Angeles, 1945

Holst, Johan and Uwe Nerlich (eds), Beyond Nuclear Deterrence: New Aims, New Arms, Crane Russak, New York, 1977

Hooker, Richard D. (ed.), Maneuver Warfare: An Anthology, Presidio, Novato, 1993

Horne, Donald, The Lucky Country, Penguin, Melbourne, 1964

Horsburgh, Nicola, China and Global Nuclear Order from Estrangement to Active Engagement, Oxford University Press, Oxford, 2015. doi.org/10.1093/acprof: oso/9780198706113.001.0001

Hurrell, Andrew, On Global Order, Oxford University Press, Oxford, 2010

Ibrugger, Lothar, 'The revolution in military affairs', NATO Parliamentary Assembly special report, November 1998, www.iwar.org.uk/rma/resources/ nato/ar299stc-e.html (retrieved 21 January 2018)

Ikenberry, G. John, After Victory: Institutions, Strategic Restraint, and the Rebuilding of International Order after Major Wars, Princeton University Press, Princeton, 2001

- Liberal Leviathan: The Origins, Crisis, and Transformation of the American World Order, Princeton University Press, Princeton, 2011

Institute of International Relations, Shanghai Academy of Social Sciences, 'Zhongmei xinxing daguo guanxi jianshe: Zhanlüe renshi yu lujing xuanze' [New type of great power relations between the US and China: Understanding strategy and future choices], Guoji Guanxi Yanjiu [Journal of International Relations], no. 6, 2014, pp. 12-36

Jacobsen, Hans-Adolf (ed.), Dokumente zum Westfeldzug, Musterschmidt, Göttingen, 1966

Jia, Qingguo and Alan D. Romberg, 'Taiwan and Tibet', in Debating China: The US-China Relationship in Ten Conversations, ed. Nina Hachigian, Oxford University Press, New York, 2014, pp. 176-97

Kagan, Donald, On the Origins of War and the Preservation of Peace, Doubleday, New York, 1995

Kahler, Miles and Scott L. Kastner, 'Strategic uses of economic interdependence: Engagement policies on the Korean Peninsula and across the Taiwan Strait', Journal of Peace Research 43, no. 5, 2006, pp. 523-41. doi.org/10.1177/ 0022343306066778 
Kaplan, Robert D., The Revenge of Geography, Random House, New York, 2012

Kastner, Scott L., 'Does economic integration across the Taiwan Strait make military conflict less likely?', Journal of East Asian Studies 6, 2006, pp. 31946. doi.org/10.1017/S1598240800004598

Kennedy, Andrew, The Conflicted Superpower: America's Collaboration with China and India in Global Innovation, Columbia University Press, New York, 2018

—_, 'Unequal partners: US collaboration with China and India in research and development', Political Science Quarterly 132, no. 1, 2017, pp. 63-86. doi.org/10.1002/polq.12573

Keohane, Robert O., 'International liberalism reconsidered', in The Economic Limits to Modern Politics, ed. John Dunn, Cambridge University Press, Cambridge, 1990. doi.org/10.1017/CBO9780511559174.008

Keohane, Robert O. and Joseph S. Nye, Power and Interdependence, Little, Brown \& Company, Boston and Toronto, 1977

Kierkegaard, Søren, Journalen JJ:167 (1843), Søren Kierkegaards Skrifter, volume 18, Søren Kierkegaard Research Center, Copenhagen, 1997

King, Amy, China-Japan Relations after World War Two: Empire, Industry and War, 1949-1971, Cambridge University Press, Cambridge, 2016. doi.org/ 10.1017/CBO9781316443439

_- 'Economic links between Australia and the United States', in Australia's American Alliance: Towards a New Era?, ed. Peter Dean, Stephan Fruehling and Brendan Taylor, Melbourne University Press, Melbourne, 2016, pp. 98118

- - Where does Japan fit in China's "new type of great power relations"?', Asan Forum, 24 March 2014

King, Amy and Evelyn Goh, 'Unpacking the economic-security nexus in Asia: New Concepts, Questions and Research Approaches', Workshop Report, ANU Research School of Asia and the Pacific, 1 October 2015, sdsc. bellschool.anu.edu.au/sites/default/files/uploads/2016-07/2015_12_15_ economic-security_nexus_asia_web.pdf (retrieved 20 January 2018)

Krasner, Stephen D., 'Are bureaucracies important? Or Allison Wonderland', Foreign Policy 7, 1972, pp. 159-79. doi.org/10.2307/1147761

Kristof, Nicholas, 'Professors, we need you', New York Times, 15 February 2015

La Nauze, J.A., Alfred Deakin: A Biography, Melbourne University Press, Melbourne, 1965 
Laruelle, Marlene, Russian Eurasianism: An Ideology of Empire, Woodrow Wilson Center Press, Washington, DC, 2008

Layne, Christopher, 'This time it's real: The end of unipolarity and the Pax Americana', International Studies Quarterly 56, no. 1, 2012, pp. 203-13. doi.org/10.1111/j.1468-2478.2011.00704.x

- 'The unipolar illusion revisited: The coming end of the United States' unipolar moment', International Security 31, no. 2, 2006, pp. 7-41. doi. org/10.1162/isec.2006.31.2.7

L'Estrange, M.G., The Internationalization of Japan's Security Policy: Challenges and Dilemmas for a Reluctant Power, Policy Papers in International Affairs 36, Institute of International Studies, University of California, Berkeley, 1990

Leveringhaus, Nicola and Kate Sullivan de Estrada, 'Between conformity and innovation: China's and India's quest for status as responsible nuclear powers', Review of International Studies 44, July 2018, pp. 482-503, doi.org/10.1017/ S0260210518000013

Lewis, Paul, 'Most Americans think US should "mind its own business" abroad, survey finds', Guardian, 3 December 2013

Libicki, Martin, Cyberdeterrence and Cyberwar, RAND, Santa Monica, 2009

Liddell Hart, B.H., A Greater than Napoleon: Scipio Africanus, Blackwood, Edinburgh, 1926

—, The Revolution in Warfare, Faber, London, 1946

Liff, Adam P. and G. John Ikenberry, 'Racing toward tragedy? China's rise, military competition in the Asia Pacific, and the security dilemma', International Security 39, no. 2, 2014, pp. 52-91. doi.org/10.1162/ISEC_a_00176

Lim, Darren J. and Rohan Mukherjee, 'What money can't buy: The security externalities of Chinese economic statecraft in post-war Sri Lanka', Asian Security, 28 December 2017. doi.org/10.1080/14799855.2017.1414045

Long, Austin, Deterrence - from Cold War to Long War, RAND, Santa Monica, 2006

Luttwak, Edward, The Grand Strategy of the Byzantine Empire, Belknap Press, Cambridge, MA, 2009

- The Grand Strategy of the Roman Empire, Johns Hopkins University Press, Baltimore, 1976 
Lyne, Roderic, 'Russia's changed outlook on the West: From convergence to confrontation', in The Russian Challenge: Chatham House Report, Royal Institute of International Affairs, London, June 2015, pp. 2-13

McGann, James G., 2015 Global Go To Think Tank Index Report, University of Pennsylvania Think Tanks and Civil Societies Program, 9 February 2016, repository.upenn.edu/cgi/viewcontent.cgi?article $=1009 \&$ context $=$ think_tanks (retrieved 1 February 2018)

McGrath, Catherine, 'Claims of Singaporean spying', $A M$, 9 August 2001, www. abc.net.au/am/stories/s343479.htm

Machiavelli, Niccolò, Discourses on Livy, trans. Harvey C. Mansfield and Nathan Tarcov, University of Chicago Press, Chicago, 15th edn, 1996

MacMillan, Margaret, The War that Ended Peace: How Europe Abandoned Peace for the First World War, Profile, London, 2013

Mahan, Alfred Thayer, The Influence of Sea Power upon History, 1660-1783, Little, Brown \& Company, Boston, 1949

Mandelbaum, Michael, 'America in a new world', American Interest 11, no. 6, 2016

- Mission Failure: America and the World in the Post-Cold War Era, Oxford University Press, New York, 2016

Maney, Kevin, 'Once drones get artificial intelligence, they'll rule the world', Newsweek, 4 September 2016

Mansfield, Edward D. and Jon C. Pevehouse, 'Trade blocs, trade flows, and international conflict', International Organization 54, no. 4, 2000, pp. 775808. doi.org/10.1162/002081800551361

Mastanduno, Michael, 'Do relative gains matter? America’s response to Japanese industrial policy', International Security 16, no. 1, 1991, pp. 73-113. doi.org/ $10.2307 / 2539052$

- 'Economics and security in statecraft and scholarship', International Organization 52, no. 4, 1998, pp. 825-54. doi.org/10.1162/00208189855 0761

, 'Order and change in world politics: The financial crisis and the breakdown of the US-China grand bargain', in Power, Order and Change in World Politics, ed. G. John Ikenberry, Cambridge University Press, Cambridge, 2014. doi.org/10.1017/CBO9781139680738 
_- 'System maker and privilege taker: US power and the international political economy', World Politics 60, no. 1, 2009, pp. 121-54

Mattis, James, 'US JFCOM's guidance for effects-based operations', Parameters 38, no. 3, 2008, p. 18, www.dtic.mil/get-tr-doc/pdf?AD=ADA490619 (retrieved 1 February 2018)

Mearsheimer, John, 'Imperial by design', National Interest, no. 111, 2011, pp. 16-34

— Liddell Hart and the Weight of History, Brassey's, London, 1988

—, 'Why is Europe peaceful today?', European Political Science 9, no. 2, 2010, pp. 387-97

__, 'Why we will soon miss the Cold War', Atlantic Monthly 266, no. 2, 1990, pp. $35-50$

Medcalf, Rory, 'The Indo-Pacific: What's in a name?', American Interest 9, no. 2, 2013

Millar, T.B., Australia’s Defence, Melbourne University Press, Melbourne, 1965

Monaghan, Andrew, 'A new "Cold War"? Abusing history, misunderstanding Russia, research paper, Russia and Eurasia Programme, May 2015, Royal Institute of International Affairs, Chatham House, London, www. chathamhouse.org/sites/files/chathamhouse/field/field_document/20150522 ColdWarRussiaMonaghan.pdf (retrieved 21 January 2018)

Morrison, Charles E., 'Interdependence, policy networks, and security in Asia Pacific', in Asia-Pacific Security: The Economics-Politics Nexus, ed. Stuart Harris and Andrew Mack, Allen \& Unwin, Sydney, 1997

Murray, Williamson, War, Strategy and Military Effectiveness, Cambridge University Press, Cambridge, 2011

Murray, Williamson and Richard Hart Sinnreich (eds), The Past as Prologue: The Importance of History to the Military Profession, Cambridge University Press, Cambridge, 2006. doi.org/10.1017/CBO9780511818943

Murray, Williamson and Wayne Wet-siang Hsieh, A Savage War: A Military History of the Civil War, Princeton University Press, Princeton, 2016

Narang, Vipin, Nuclear Strategy in the Modern Era: Regional Powers and International Conflict, Princeton University Press, Princeton, 2014. doi.org/ $10.1515 / 9781400850402$ 
National Security Council Report 68, 'United States objectives and programs for national security', 14 April 1950, fas.org/irp/offdocs/nsc-hst/nsc-68.htm (retrieved 30 January 2018)

Nisbett, Richard E., The Geography of Thought: How Asians and Westerners Think Differently ... and Why, Free Press, New York, 2003

Note Verbale to the United Nations Secretary-General, May 2009, quoted in Asia-Pacific Maritime Security Strategy, Department of Defense, Washington, DC, July 2015

Obama, Barack, 60 Minutes Central Broadcasting Station interview, 26 September 2014, broadcast 28 September 2014, www.cbsnews.com/news/ obama-u-s-underestimated-rise-of-isis-in-iraq-and-syria/ (retrieved 30 January 2018)

Oelrich, I.C., 'Sizing post-Cold War nuclear forces', Institute for Defense Analysis paper P-3650, October 2001

Office of the Secretary of Defense, Annual Report to Congress: Military and Security Developments Involving the People's Republic of China 2016, Washington, DC, April 2016

Ohmae, Kenichi, The End of the Nation State: The Rise of Regional Economies, Free Press Paperbacks, New York, 1995

Oliver, Kevin, 'Climate dynamics', University of Southampton School of Ocean and Earth Science lecture slides, undated, slideplayer.com/slide/10423511/ (retrieved 21 January 2018)

Oneal, John R., Frances Oneal, Zeev Maoz and Bruce Russett, 'The liberal peace: Interdependence, democracy, and international conflict, 1950-85', Journal of Peace Research 33, no. 1, 1996, pp. 11-28. doi.org/10.1177/ 0022343396033001002

Oneal, John R. and Bruce Russett, 'The Kantian peace: The Pacific benefits of democracy, interdependence, and international organizations, 18851992', World Politics 52, no. 1, 1999, pp. 1-37. doi.org/10.1017/S004388 7100020013

O'Neill, Robert, 'Arms control and the balance of power', in Hedley Bull on Arms Control, ed. Robert O'Neill and David N. Schwartz, St Martin's Press, New York, 1987, pp. 41-57. doi.org/10.1007/978-1-349-09293-2_4

—, Australia in the Korean War 1950-53, vol. 1: Strategy and Diplomacy, Australian War Memorial and Australian Government Publishing Service, Canberra, 1981 
- Australia in the Korean War 1950-53, vol. 2: Combat Operations, Australian War Memorial and Australian Government Publishing Service, Canberra, 1985

—- Strategic Studies and Political Scientists: Strategic Studies and Its Critics Revisited, SDSC Working Paper No. 40, Canberra, 29 April 1981

Pan Fei, 'Zhongmei zai yatai diqu de zhanlüe hudong yu Obama zhengfu de duitai zhengce' [Sino-American strategic interaction in the Asia Pacific and the Obama Administration's Taiwan policy], Taihai Yanjiu [Taiwan Straits Studies], February 2015, pp. 76-84

Paret, Peter, with Gordon A. Craig and Felix Gilbert (ed.) Makers of Modern Strategy from Machiavelli to the Nuclear Age, Clarendon Press, Oxford, 1986

Pempel, T.J. (ed.), The Economic-Security Nexus in Northeast Asia, Routledge, New York, 2013

Perlez, Jane,'Tribunal rejects Beijing's claims within South China Sea', New York Times, 12 July 2016

Perry, William, 'Pursuing a strategy of mutual assured safety', remarks at the National Press Club, Washington, DC by the US Secretary of Defense, 5 January 1995

Phillips, Andrew, From Hollywood to Bollywood? Australia's Indo/Pacific Future in a Contested Asia, Australian Strategic Policy Institute, Canberra, 12 October 2013

Platias, Athanassios G. and Constantios Koliopoulos, Thucydides on Strategy: Athenian and Spartan Grand Strategies and their Relevance Today, Eurasia, Athens, 2006

Polachek, Solomon William, 'Conflict and trade', Journal of Conflict Resolution 24, no. 1, 1980, pp. 55-78. doi.org/10.1177/002200278002400103

Policy Subcommittee of the Strategic Advisory Group, 'Essentials of Post-Cold War deterrence', 1995, www.nukestrat.com/us/stratcom/sagessentials.htm (retrieved 29 January 2018)

Pollard, Robert A., Economic Security and the Origins of the Cold War, 1945-1950, Columbia University Press, New York, 1985

Pollins, Brian M., 'Does trade still follow the flag?', American Political Science Review 83, no. 2, 1989, pp. 465-80. doi.org/10.2307/1962400 
Pomfret, John, 'US takes a tougher tone with China', Washington Post, 30 July 2010, www.washingtonpost.com/wp-dyn/content/article/2010/07/29/AR20 10072906416.html (retrieved 20 January 2018)

Posen, Barry, 'Pull back: The case for a less activist foreign policy', Foreign Affairs 92, no. 1, 2013, pp. 116-29

Public Administration Select Committee, Who Does UK National Strategy? First Report of Session 2010-11, UK House of Commons, Stationery Office, London, 18 October 2010, publications.parliament.uk/pa/cm201011/ cmselect/cmpubadm/435/435.pdf (retrieved 29 January 2018)

Queloz, Dimitry, De la manoeuvre napoléonienne à l'offensive à outrance: La tactique générale de l'armée française 1871-1914, Economica, Paris, 2009

Quimby, Robert S., The Background of Napoleonic Warfare: The Theory of Military Tactics in Eighteenth-century France, Columbia University Press, New York, 1957

Raby, Geoff, 'It's impossible for Xi Jinping to give in to The Hague', Australian Financial Review, 14 July 2016

Rahe, Paul, The Grand Strategy of Classical Sparta: The Persian Challenge, Yale University Press, New Haven, 2015

Rajaratnam, S., 'Singapore into the 21st century', speech, Singapore Association for the Advancement of Science seminar, Singapore Science Centre, 20 December 1979

Ravenhill, John, 'Production networks and Asia's international relations', in Oxford Handbook of the International Relations of Asia, ed. Saadia Pekkanen, John Ravenhill and Rosemary Foot, Oxford University Press, Oxford, 2014, pp. 348-68

'Rhetorical terms', in Writing Across the Curriculum, Appalachian State University, undated, wac.appstate.edu/wac-glossary-terms/general-writingterms/d-rhetorical-terms (retrieved 21 January 2018)

Roberts, Brad, The Case for US Nuclear Weapons in the 21st Century, Stanford University Press, Stanford, 2016

Robinson, Linda, Paul D. Miller, John Gordon IV, Jeffrey Decker, Michael Schwille and Raphael S. Cohen, Improving Strategic Competence: Lessons from 13 Years of War, RAND, Santa Monica, 2014 
Rosecrance, Richard, 'Economics and national security: The evolutionary process', in Asia-Pacific Security: The Economics-Politics Nexus, ed. Stuart Harris and Andrew Mack, Allen \& Unwin, Sydney, 1997

- The Rise of the Trading State: Commerce and Conquest in the Modern World, Basic Books, New York, 1986

Rosecrance, Richard and Steven E. Miller (eds), The Next Great War? The Roots of World War I and the Risk of US-China Conflict, MIT Press, Cambridge, MA, 2015

Ross, Robert S., 'China's naval nationalism', International Security 34, no. 2, 2009, pp. 46-81, doi.org/10.1162/isec.2009.34.2.46

Schelling, Thomas C., Arms and Influence, Yale University Press, New Haven, 1966

— The Strategy of Conflict, Harvard University Press, Cambridge, MA, 1960

Schultz, George, William Perry, Henry Kissinger and Sam Nunn, 'Toward a nuclear free world', Wall Street Journal, 15 January 2008, www.nti.org/media/ pdfs/NSP_op-eds_final_.pdf?_=1360883065 (retrieved 29 January 2018)

Shulman, Marshall, 'Toward a Western philosophy of coexistence', Foreign Affairs 52, no. 1, 1973, pp. 35-58. doi.org/10.2307/20038029

- 'What does security mean today?', Foreign Affairs 49, no. 4, 1971, pp. 607-18. doi.org/10.2307/20037868

Singer, P.W., Wired for War: The Robotics Revolution and Conflict in the 21st Century, Penguin, London, 2009

Snyder, Jack, The Ideology of the Offensive: Military Decision Making and the Disasters of 1914, Cornell University Press, Ithaca, 1984

Soeya, Y., 'Japan: Normative constraints versus structural imperatives', in Asian Security Practice: Material and Ideational Influences, ed. M. Alagappa, Stanford University Press, Stanford, 1998

Sokov, Nikolai, 'Russian nuclear strategy: Background, current status, future', Center for Nonproliferation Studies presentation, www.nonproliferation.org/ wp-content/uploads/2016/06/Nikolai-Sokov-Russian-Nuclear-Strategy.pdf (retrieved 29 January 2018)

Solingen, Etel, Nuclear Logics: Contrasting Paths in East Asia and the Middle East, Princeton University Press, Princeton, 2007 
Strachan, Hew, The Direction of War: Contemporary Strategy in Historical Perspective, Cambridge University Press, Cambridge, 2013. doi.org/10.1017/ CBO9781107256514

Sutter, Robert, Taiwan's Future: Narrowing Straits, National Bureau of Asian Research Analysis, May 2011

Taleb, Nassim Nicholas, The Black Swan: The Impact of the Highly Improbable, Random House, New York, 2010

Tange, Sir Arthur, Defence Policy Administration and Organisation: Selected Lectures 1971-1986, Australian Defence Force Academy, University of New South Wales, Canberra, 1992

Taylor, Brendan and Bruce Luckham, 'Economics and security', in Strategy and Security in the Asia Pacific, ed. Robert Ayson and Desmond Ball, Allen \& Unwin, Sydney, 2006, pp. 138-51

Tetlow, Gemma, 'Treasury made no plans for Brexit, says new head, Tom Scholar', Financial Times, 7 July 2016

'Think Tank Index', Foreign Policy, undated, web.archive.org/web/2009 0119095446/http://www.foreignpolicy.com/story/cms.php?story_id=4598 \&page=3 (retrieved 1 February 2018)

Thompson, Loren, 'Pentagon budget headed below 3\% of GDP as warfighting edge wanes', Forbes, 2 February 2015

Thucydides, History of the Peloponnesian War, trans. Rex Warner with introduction and notes by M. I. Finely, Penguin Books, Harmondsworth, 1972

- The Landmark Thucydides: A Comprehensive Guide to the Peloponnesian War, ed. Robert B. Strassler with introduction by Victor Davis Hanson, Simon \& Schuster, New York, 1998

Tingle, Laura, Political Amnesia: How We Forgot to Govern, Quarterly Essay, no. 60,2015

Tuchman, Barbara W., The Proud Tower: A Portrait of the World Before the War: 1890-1914, Hamish Hamilton, London, 1966

Tucker, Nancy Bernkopf, Strait Talk: United States-Taiwan Relations and the Crisis with China, Harvard University Press, Cambridge, MA, 2009

Turnbull, Malcolm, 'IISS Shangri-La Dialogue 2017 Keynote Address', Singapore, 2 June 2017 
Umbach, F., 'Russia’s changing threat perceptions', International Politik 4, no. 1, 2003, pp. 53-7

UK Cabinet Office, The Report of the Iraq Inquiry [Chilcot Report], 6 July 2016, www.gov.uk/government/publications/the-report-of-the-iraq-inquiry (retrieved 16 January 2018)

UK Ministry of Defence, '2010 to 2015 Government Policy; UK Nuclear Deterrent', www.gov.uk/government/publications/2010-to-2015-governmentpolicy-uk-nuclear-deterrent/2010-to-2015-government-policy-uk-nucleardeterrent (retrieved 4 March 2018)

US Department of Defense, Summary of the 2018 National Defense Strategy of the United States of America: Sharpening the American Military's Competitive Edge, Department of Defense, Washington, DC, 2018, www.defense.gov/ Portals/1/Documents/pubs/2018-National-Defense-Strategy-Summary.pdf (retrieved 28 January 2018)

von Moltke, Helmuth, Kriegsgeschichtliche Einzelschriften, Grosser Generalstab, Prussian Armee, 1880

Walt, Stephen, 'The end of the US era', National Interest, no. 116, 2011, pp. 6-16

- 'The renaissance of security studies', International Studies Quarterly, no. 2, 1991, pp. 211-39

Waltz, Kenneth N., 'The myth of national interdependence', in The International Corporation, ed. Charles E. Kindleberger, MIT Press, Cambridge, MA, 1970, pp. 205-23

Weldes, Jutta, 'Constructing national interests', European Journal of International Relations 2, no. 3, 1996, pp. 275-318. doi.org/10.1177/135406619600 2003001

'What China wants', Economist 412, no. 8901, 21 August 2014

White, Hugh, The China Choice: Why America Should Share Power, Black Inc., Melbourne, 2012

- 'Why war in Asia remains thinkable', Survival 50, no. 6, 2008-09, pp. 85-104. doi.org/10.1080/00396330802601875

Wilke, A. and R. Mata, 'Cognitive bias', Encyclopedia of Human Behavior, 2nd edn, vol. 1, ed. V.S. Ramachandran, Academic Press, Cambridge, MA, 2012

Wohlstetter, Albert, 'The delicate balance of terror', Foreign Affairs, January, 1959, pp. 211-34. doi.org/10.2307/20029345 
World Bank, 'GDP (current US\$)', data.worldbank.org/indicator/NY.GDP. MKTP.CD (retrieved 30 January 2018)

—_, 'GDP per capita, PPP (current international \$)', data.worldbank.org/ indicator/NY.GDP.PCAP.PP.CD (retrieved 30 January 2018)

_ ' 'Military expenditure (\% of GDP)', data.worldbank.org/indicator/MS.MIL. XPND.GD.ZS (retrieved 30 January 2018)

Wu Xinbo and Michael Green, 'Regional security roles and challenges', in Debating China: The US-China Relationship in Ten Conversations, ed. Nina Hachigian, Oxford University Press, New York, 2014, pp. 198-220

Yan Xuetong, 'From keeping a low profile to striving for achievement', Chinese Journal of International Politics 7, no. 2, 2014, pp. 153-84. doi.org/10.1093/ cjip/pou027

Yinhong Shi, 'The United States, East Asia, and Chinese "Triumphalism", in China's Rise and Regional Integration in East Asia, ed. Yong Wook Lee and Key-young San, Routledge, Abingdon, 2014, pp. 40-53

Zellen, Barry Scott, State of Doom: Bernard Brodie, the Bomb, and the Birth of the Bipolar World, Continuum, London, 2012

Zuber, Terence, Inventing the Schlieffen Plan: German War Planning1871-1914, Oxford University Press, Oxford, 2002. doi.org/10.1093/acprof:oso/ 9780199250165.001.0001 
